\title{
pommalina
}

(8)

\section{Teatro tomo I: Sedecias}

Autor(es): $\quad$ Cruz, Luís da

Publicado por: Imprensa da Universidade de Coimbra

URL

persistente: URI:http://hdl.handle.net/10316.2/2963

DOI: $\quad$ DOI:http://dx.doi.org/10.14195/978-989-26-0483-1

Accessed : $\quad$ 26-Apr-2023 15:23:53

A navegação consulta e descarregamento dos títulos inseridos nas Bibliotecas Digitais UC Digitalis, UC Pombalina e UC Impactum, pressupõem a aceitação plena e sem reservas dos Termos e Condições de Uso destas Bibliotecas Digitais, disponíveis em https://digitalis.uc.pt/pt-pt/termos.

Conforme exposto nos referidos Termos e Condições de Uso, o descarregamento de títulos de acesso restrito requer uma licença válida de autorização devendo o utilizador aceder ao(s) documento(s) a partir de um endereço de IP da instituição detentora da supramencionada licença.

Ao utilizador é apenas permitido o descarregamento para uso pessoal, pelo que o emprego do(s) título(s) descarregado(s) para outro fim, designadamente comercial, carece de autorização do respetivo autor ou editor da obra.

Na medida em que todas as obras da UC Digitalis se encontram protegidas pelo Código do Direito de Autor e Direitos Conexos e demais legislação aplicável, toda a cópia, parcial ou total, deste documento, nos casos em que é legalmente admitida, deverá conter ou fazer-se acompanhar por este aviso. 


\title{
PortVgaliae \\ Monvmenta Neolatina
}

\author{
Vol. V
}

\section{LUÍs DA CRUZ}

TEATRO

Томо I

\section{SEDECIAS}


(Página deixada propositadamente em branco) 


\section{PORTVGALIAE \\ MONVMENTA NEOLATINA}

Coordenação Científica

A $\quad \mathrm{P} \quad \mathrm{E} \quad \mathrm{N} \quad \mathrm{E} \quad \mathrm{L}$

Associação Portuguesa de Estudos Neolatinos

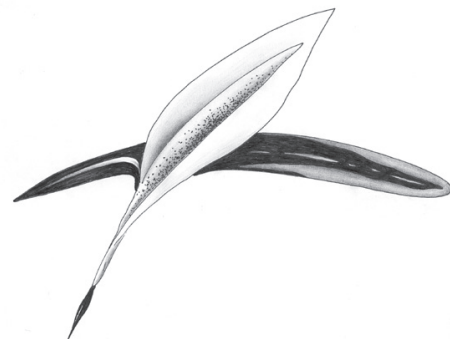

$\begin{array}{llllll}\text { A P } & \text { E } & \text { N } & \text { E } & \text { L }\end{array}$ 


\section{COORDENAÇÃO CIENTÍFICA}

Associação Portuguesa de Estudos Neolatinos - APENEL

\section{DIRECÇÃO}

Sebastião Tavares de Pinho, Arnaldo do Espírito Santo,

Virgínia Soares Pereira, António Manuel R. Rebelo, João Nunes Torrão, Carlos Ascenso André,

Manuel José de Sousa Barbosa

\section{COORDENAÇÃO EDITORIAL}

Maria João Padez de Castro

\section{EDIÇÃO}

Imprensa da Universidade de Coimbra

Email: imprensauc@ci.uc.pt

URL: http://www.uc.pt/imprensa_uc

Vendas online: http://siglv.uc.pt/imprensa/

\section{CONCEPÇÃO GRÁFICA}

António Barros

PRÉ-IMPRESS ÃO

Sereer, soluções editoriais

\section{IMPRESSÃO E ACABAMENTO}

Sereer, soluções editoriais

\section{ISBN}

978-989-8074-97-3

\section{DEPÓSITO LEGAL}

296851/09

\section{OBRA PUBLICADA COM O APOIO DE:}
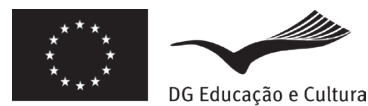

Programa «Cultura»
Projecto financiado com o apoio da Comissão Europeia. A informação contida nesta publicação vincula exclusivamente o autor, não sendo a Comissão responsável pela utilização que dela possa ser feita. 
Portvgaliae Monvmenta NeOlatina

VOL. V

LUÍS DA CRUZ

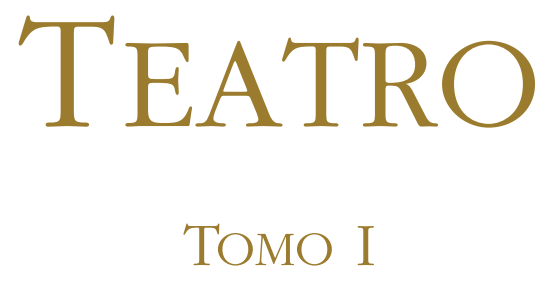

SEDECIAS

Estabelecimento do texto latino

Introdução, tradução, notas e comentário

Manuel José de Sousa Barbosa
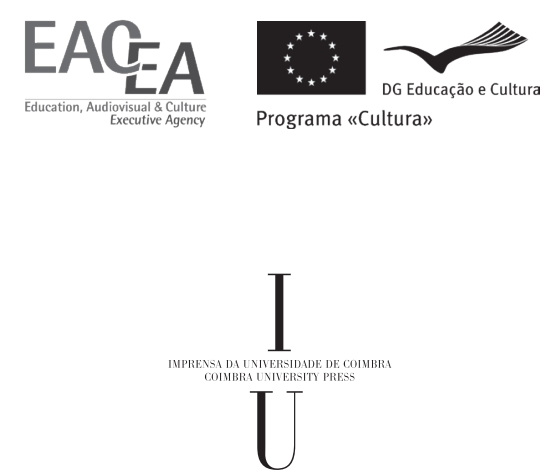
(Página deixada propositadamente em branco) 


\section{INTRO DUÇ Ão}

\section{Esboço biográfico}

Como sucede em geral com personalidades do século XVI, também os dados biográficos do Jesuíta Luís da Cruz se nos apresentam escassos e de contornos pouco definidos, como mostra a notícia inserta na Biblioteca Lusitana cujo início transcrevemos:

"P. Luiz da Cruz natural de Lisboa e filho de Leonardo da Cruz, e Leonor Lopes. Vestio a roupeta da Companhia de Jesus em o noviciado de Coimbra ao primeiro de Janeiro de 1558 (...) Foy insigne Humanista, excellente Poeta, e muito perito nos mysterios das Línguas Latina, e Grega. Pelo espaço de doze annos dictou Rhetorica, e Escritura Sagrada. No púlpito encheo as obrigaçoens de Orador consumado. Falleceo piamente no Collegio de Coimbra a 18 de Julho de 1604". ${ }^{1}$

Igualmente vagas e genéricas são as memórias sucintas dele traçadas em obras de âmbito geral, de que Barbosa Machado faz um apanhado, nas quais se realçam, quase invariavelmente, os seus dotes de poeta e orador insigne, com expressões como "poeta eximius", "concionator egregius", "predicatore famoso", "poeta di nobili fama", "scriptore insigne".

Para ilustrar com mais pormenores esta síntese geral da vida do nosso mais famoso dramaturgo jesuíta, será preciso efectuar uma leitura atenta da correspondência jesuítica, o que ainda não terá sido feito de forma exaustiva, em ordem a retirar daí dados mais concretos e esclarecedores da sua personalidade, designadamente os que têm a ver com a sua faceta de pedagogo e humanista.

Luís da Cruz terá chegado ao Colégio das Artes de Coimbra depois de já ter frequentado em Lisboa o Colégio de Santo Antão, e logo se terá feito notar pelo seu talento, como o dá a entender o seguinte passo duma carta do Irmão Nicolau Gracida ao P. Manuel Lopes, onde se faz referência aos recém-chegados ao Colégio: "Otro es una singular abilidad que anduvo en la primera de Lisbona, de muy poca

\footnotetext{
${ }^{1}$ Diogo Barbosa Machado, Bibliotheca Lusitana, Lisboa 1752, T. III, s. u. "P. Luiz da Cruz".
} 
edad, por nombre Luiz de la Cruz". ${ }^{2}$ Em Coimbra, Luís da Cruz teve oportunidade de completar a sua formação humanística e retórica numa conjuntura única, rodeado duma elite de grandes mestres. Alguns deles deixaram larga fama atrás de si, como João Pedro Perpinhão, Manuel Álvares, Cipriano Soares e Miguel Venegas. Foi com eles que Luís da Cruz conviveu de perto nos seus primeiros anos de Colégio das Artes e, ainda adolescente, beneficiou sem dúvida largamente do saber e do exemplo destes homens de elevada envergadura humanista. João Pedro Perpinhão (1530-1566) foi um dos grandes animadores da implantação do modelo didácticopedagógico da Companhia no Colégio das Artes, com ideias e procedimentos que se veriam retomados noutros colégios e, mais tarde, consagrados nas normas da Ratio Studiorum ${ }^{3}$. Ficou célebre sobretudo como um exímio orador, de estilo ciceroniano. Os seus discursos, muito apreciados, foram objecto de múltiplas edições até ao séc. XVIII. Manuel Álvares (1526-1583) é sobejamente conhecido como o criador duma nova gramática da língua latina, pensada como alternativa às existentes então e que não satisfaziam plenamente os mestres jesuítas. ${ }^{4}$ Essa gramática viria a conhecer grande fortuna, fora e dentro da Companhia, com múltiplas e sucessivas edições em várias partes do mundo. ${ }^{5}$ Cipriano Soares deixou igualmente profunda marca na Companhia com o seu célebre compêndio De arte rhetorica libri tres, de que constam edições em grande número de cidades da Europa, o que terá certamente a ver com o facto de ser um dos livros de retórica recomendados para os colégios na Ratio Studiorum. ${ }^{6}$ Quanto ao P. Miguel Venegas, dava nesta altura, em Coimbra, os primeiros passos na sua actividade de grande dramaturgo, com peças que, a julgar pelos vários exemplares manuscritos do seu texto, dispersos por várias cidades da Europa, conheceram enorme sucesso. Venegas terá sido mesmo, a partir de certa altura, uma espécie de encenador itinerante dos seus dramas, todos eles tragédias bíblicas, em colégios da Companhia. ${ }^{7}$ Luís da Cruz, enquanto aluno de Venegas, terá acompanhado de perto e com entusiasmo esse trabalho de dramaturgo e encenador,

\footnotetext{
${ }^{2}$ Cf. Serafim da Silva Leite, ed., Monumenta Brasiliae siue Complementa Azevediana, Roma, Monumenta Historica Societatis Iesu (MHSI), 1968, vol. V, p. 158. Carta enviada de Coimbra a 14 de Fevereiro de 1558.

3 Por Ratio Studiorum deverá entender-se a carta-magna do ensino jesuítico, compilando um conjunto de normas e disposições relativas ao funcionamento didáctico-pedagógico dos colégios da Companhia. Fruto duma experiência intensamente reflectida e partilhada desde os primeiros momentos de vida dos colégios de ensino público dirigidos pela Companhia, viria a ter a sua redacção definitiva em 1599.

${ }^{4}$ De institutione grammatica libri três, Lisboa, 1572, na oficina de João Barreira.

${ }^{5}$ Usada pelos Jesuítas nos seus colégios, foi por eles levada para o Japão e para a China, onde em 1869 conheceu uma edição com tradução chinesa, publicada em Xangai. Foi ainda usada por James Joyce (1882-1941). Cf. Companion to Neo-Latin Studies, part I (...), by Jozef Ijsewijn, Lovain, Peeters Press, 1990, p. 119.

${ }^{6}$ A primeira edição do De rhetorica de Cipriano Soares saiu no ano de 1562, em Coimbra, na tipografia de João Barreira.

7 Leia-se, a este propósito, Nigel Griffin, "Miguel Venegas and the sixteenth-century jesuit school drama", The Modern Language Review, Cambridge 68 (1973), pp. 796-806.
} 
recolhendo ensinamentos e adquirindo uma experiência que explicarão, certamente, muito do que ele viria a ser. ${ }^{8}$

Concluídos os estudos de Filosofia e Teologia em Coimbra no verão de 1563, o ainda Irmão Luís da Cruz rumará para o colégio de S. Paulo em Braga, ${ }^{9}$ onde inicia o seu longo e frutuoso magistério de mestre de humanidades e retórica. É legítimo pensar que esta ida para Braga terá ficado a dever-se ao facto do P. Inácio de Azevedo, que fora Reitor do Colégio das Artes entre os anos 1556 e 1559, ter um bom conhecimento deste noviço tão promissor, então na casa dos vinte anos, e estar assim interessado em vê-lo integrar o quadro de docentes do colégio de que era agora reitor.

Suspeitamos que terá sido certamente em Braga que Luís da Cruz ensaiou os primeiros passos da actividade de dramaturgo que o viria a celebrizar em toda a Europa. Os primeiros frutos dessa actividade parecem de facto ter surgido na cidade dos arcebispos, embora não tenhamos até hoje provas concretas, a saber, os textos. Tudo indica que serão da autoria de Luís da Cruz duas peças de que surge notícia na correspondência jesuítica relativa ao ano de 1564. A primeira é uma écloga representada na semana da Páscoa desse ano, mais concretamente, no dia 5 de Abril, na presença de D. Frei Bartolomeu dos Mártires e de "outra gente honrada da cidade". Compô-la um irmão, que compusera igualmente para a mesma ocasião um discurso de louvor ao Arcebispo. ${ }^{10}$ A segunda vem referida como uma comédia, composta por um irmão, no dia 22 de Julho de 1564, por ocasião da solene distribuição dos prémios. ${ }^{11}$ Estas informações sobre os eventos teatrais deixam no anonimato o nome do autor da peça. Sabendo-se porém, pelos catálogos enviados para Roma, que Luís da Cruz já se encontrava nesse ano em Braga e que era o mestre da $1^{\text {a }}$ classe, ${ }^{12}$ é de presumir, com fundadas razões, que este Irmão que reunia em si jeito para discursar e para compor teatro, fosse precisamente Luís da Cruz.

\footnotetext{
8 Vide as interessantes considerações sobre este convívio entre Venegas e Luís da Cruz, que se terá iniciado no Colégio de Santo Antão em Lisboa, e as eventuais influências recolhidas no teatro deste último em Margarida Miranda, "Miguel Venegas e Luís da Cruz, S. I.: o mestre e o discípulo" in Luís da Cruz, S. J., o teatro jesuitico nos seus primórdios (Actas de colóquio comemorativo do IV centenário da morte do dramaturgo (1604-2004), coord. Aires A. Nascimento e Manuel de Sousa Barbosa, Lisboa, Centro de Estudos Clássicos, 2005, pp. 75-88.

9 Este colégio foi confiado aos Jesuítas em 1560, pelo Arcebispo de Braga, D. Frei Bartolomeu dos Mártires, sendo o seu primeiro Reitor o P. Inácio de Azevedo.

10 "(...) El postrero dia de Pascoa estando presente el Arçobispo desta diócese (que aquel dia avía comido en casa) con un Obispo y otra gente honrada desta ciudad, recitó un Hermano nuestro una oración que en loor del Arçobispo avia hecho; y después de se defender unas conclusiones de philosophia y lógica, instando algumas vezes el Arçobispo en los argumentos de los otros, se representó una égloga muy a propósito que este mesmo Hermano avía compuesto. Hiziéronlo los studiantes con mucha gracia y buena acción. (...)" - Quadrimestre do Colégio de Braga, com data de 30 de Abril de 1564. Cf. Monumenta Brasiliae...cit., V, p. 367.

${ }^{11}$ Cf. Archivum Romanum Societatis Iesu (ARSI), Lus. 52, fl. 89r-90v. (Quadrimestre escrita pelo P. António Rocha).

12 No plano de estudos dos Jesuítas, a $1^{a}$ classe era a mais avançada.
} 
Regressando a Coimbra após uma estadia em Braga de dois ou três anos ${ }^{13}$, Luís da Cruz vai dar então início ao período mais fecundo da sua actividade de dramaturgo, paralelamente ao seu munus de mestre de humanidades. Entre 1568 e 1578 compõe sucessivamente a tragicomédia Prodigus (1568), a tragédia Sedecias (1570), a comédia Vita Humana (1571 ou 1572), a tragicomédia Iosephus (1574) e a tragicomédia Manasses (1578), esta última a única a não ser representada, mercê dos tristes acontecimentos de Alcácer-Quibir que deixaram o país de luto com a morte do rei.

As vicissitudes políticas por que viria a passar depois o país, designadamente com a dominação filipina a partir de 1580, não deixaram de repercutir-se na vida do nosso jesuíta, que passou, por via disso, por algumas tribulações. De facto, vemolo alinhado no movimento de resistência ao domínio filipino, ao lado do Prior do Crato, com a composição e publicação de epigramas, certamente bem mordazes, contra Filipe II, no ano de 1584. Esteve prestes a ser expulso da Companhia, valendo-lhe neste caso a sua condição de poeta, que funcionou como atenuante. $O$ castigo resumiu-se a um "exílio" de quatro anos, nas terras frias de Bragança, onde a Companhia também possuía um colégio. ${ }^{14}$

No ano de 1590 encontra-se de novo em Coimbra, onde continuará a exercer o seu magistério de humanidades ainda por alguns anos, se bem que de forma penosa, por sofrer de gota, sendo transportado para as aulas em cadeira de rodas. ${ }^{15}$ Quanto à sua actividade de dramaturgo, há sinais de uma esporádica retoma com a composição e representação da Écloga Polychronius, em Évora, no ano de 1592. Nesta fase derradeira de sua vida foi incumbido pelos superiores de preparar para edição a sua obra teatral.

Sobre o teatro de Luís da Cruz, deixou o eminente jesuíta António Possevino (1533-1611) um expressivo elogio na sua obra Apparatus Sacer ad Scriptores Veteris et Noui Testamenti (Veneza, 1603-06), de que Barbosa Machado transcreve o seguinte excerto:

"Quas ego perlegens fateor me, et multiformem Dei sapientiam, et multitudinem eius misericordiarum saepius collaudasse, qui quod peroptandum est in flagitiosorum histrionum Comoediis ablegandis, rationem etiam hoc aeuo monstrauerit, qua omnis omnium hominum status iuuari queat cum uera

13 É difícil precisar os anos que passou em Braga. Como os catálogos já não registam a sua presença em Coimbra em Setembro de 1563, é de supor que já se encontraria em Braga. Registos inequívocos da sua presença nesta cidade surgem datados de Maio e Setembro de 1564 (Cf. ARSI, Lus. 43-I, 209r-210r).

14 Ver relato fundamentado deste incidente político da vida de Luís da Cruz em ClaudeHenri Frèches, Le théâtre Neo-latin au Portugal (1550-1745), Paris, Librairie A. G. Nizet - Lisboa, Livraria Bertrand, 1964, p. 241-242.

15 Cf. António Franco, Ano Santo da Companhia de Jesus em Portugal nas memórias breves e ilustres de muitos homens insignes em virtudes com que Deus a enriqueceu, distribuidas pelos meses e dias de todo o ano, Porto, 1930, p. 394. 
iucunditate. Res uero ipsae tam uariae, atque multiplices adeo latine, et proprie, idque non soluta, sed ligata oratione enuntiatae indicant, quaenam inde ad excolendam etiam linguam promi queat utilitas." 16

[Trad.: "Ao lê-las, confesso que muitas vezes enalteci com elogios não só a multiforme sabedoria de Deus, mas também a multidão das suas misericórdias, porque ele mostrou de que forma também neste tempo uma situação de vida de qualquer pessoa pode ser ajudada com verdadeiro encanto, o que é muito desejável quando se trata de contrariar comédias de actores escandalosos. ${ }^{17}$ Por outro lado, a própria temática, tão variada e múltipla, muito bem enunciada em latim e de forma apropriada, e tudo isto não em prosa, mas em verso, mostra que proveito se poderá retirar daqui em ordem também ao cultivo da língua."]

\section{Obra escrita}

Como vimos no esboço biográfico acabado de apresentar, Luís da Cruz é referido, nas várias memórias que dele se traçam, como insigne orador e poeta. Foi, porém, na poesia que ele deixou a sua fama consolidada, com dois volumes saídos do prelo, um relativo à sua paráfrase dos salmos e outro ao seu teatro. ${ }^{18}$ Toda a sua restante obra continua inédita. Vamos aqui apresentar uma resenha de toda a obra literária de Luís da Cruz, manuscrita ou impressa, com indicação do título de todas as suas composições, por género, quer em prosa quer em verso, e da respectiva localização.

I - EM PROSA:

\section{Discursos:}

- "In Diuae Elisabethae laudem Lusitaniae Reginae oratio" (BNL, Cod. 3308, pp. 997-1011;

- "De studio religionis S. Elisabethae et de ea tuenda oratio". Ano de 1576. (BGUC, Cod. 993, fls.177r-181v);

16 D. Barbosa Machado, op. cit., Tomo III, p. 90.

17 Alusão à Comedia dell'Arte.

18 A paráfrase poética dos Salmos foi editada pela primeira vez em Ingolstadt, no ano de 1597: Interpretatio poetica latine in centum quinquaginta psalmos, autore Ludouico Crucio Olysipponensi. Ingolstadii, Excudebat Adam Sartorius. Anno M.D.XCVII. Seria editada ainda em Madrid (1600), em Nápoles (1601), em Milão (1604), em Veneza (1604), em Lyon (1608) e em Colónia (1612), em vários formatos, de que se destaca um $16^{\circ}$. O seu teatro foi editado em Lyon, em 1605, no seguinte volume: Tragicae comicaeque actiones a Regio Artium Collegio Societatis IESV, datae Conimbricae in publicum theatrum, auctore Ludouico Crucio eiusdem Societatis olisiponensi, nunc primum in lucem editae et sedulo diligenterque recognitae. Cum privilegio. Lugduni, apud Horatium Cardon, 1605. 


\section{Biografia:}

- "De uita et moribus Dominici Ioannis libri três " (ARSI, Lus. 59, fl. 5-98)19

\section{Prefácios poéticos:}

- "Beneuolo amicoque lectori" in Tragicae comicaeque actiones..., fls. ***1-**8;

- "Ad beneuolum eruditumque lectorem" (BNL, cod. 3234, pp. 1-15). ${ }^{20}$

\section{Epístolas:}

- "La emienda de Terentio", para o P. General em Roma. Coimbra, 1572 (ARSI, Lus. 70, fl. 313r);

- [Para o P. General, sobre o Colégio de Bragança. Bragança, 20 de Janeiro de 1587]. (ARSI, Lus. 70, fl. 195vr);

- "Horatio Cardonio Bibliopolae Lugdunensi, Ludouicus Crucius ex Societate IESV S.” in Tragicae comicaeque actiones..., cit., p. *2;

- "Ioanni Brigantino antistiti Visensi amplissimo, Ludouicus Crucius", Ib., p. *3.

\section{Apontamentos de aulas:}

- "Aduersaria in quibus continentur quamplurima scitu digna tradita a religiosiss[imo] necnon sapientiss[imo] magistro Ludouico a Cruce anno a Christo nato 1578. Conimbricae in primo gymn[asio]." (ANTT, Ms. Da Livraria 2209, fls. 132r-136r). ${ }^{21}$

II - EM VERSO:

\section{Paráfrase bíblica:}

- Interpretatio poetica latine in centum quinquaginta psalmos (impresso); ${ }^{22}$

- "Ex ecclesiastice capite 2b sententiae":

- Mulieris bonae beatus uir, numerus enim annorum illorum duplex. Sentent[ia] $1^{\mathrm{a}}$. Ad Reginam Augustam (BGUC, cod. 993, fl. 230v);

- Ad reg[inam] Aug[ustam]: Mulier fortis oblectat uirum suum, et annos uitae illius in pace implebit. Sentent[ia] $2^{\text {a }}$ (loc. cit.);

- Ad reg[inam] Aug[ustam]: Pars bona mulier bona, in parte bona timentium Deum. Sentent[ia] $3^{\mathrm{a}}$ (loc. cit.);

- Ad reg[inam] Aug[ustam]. Disciplina illius datum Dei est: Mulier sensata et tacita. Sent[entiam] 4 (ibid., fl. 231r);

19 Vida do irmão Domingos João, coadjutor temporal da Companbia de Jesus, conforme vem mencionada por Barbosa Machado, na sua Biblioteca. Este jesuíta, homenageado por Luís da Cruz nesta biografia, encontrava-se no Colégio das Artes na altura da representação da tragédia Sedecias. A sua capacidade de trabalho e de organização revelou-se fundamental para o êxito desta aparatosa encenação. Cf. anexo 1 a esta "Introdução".

20 Texto editado e traduzido, com breve nota introdutória, em Manuel Barbosa, "A poética teatral dos Jesuítas: O prefácio que ficou inédito", Euphrosyne 28 (2000), 375-405.

${ }^{21}$ Poderá tratar-se de apontamentos coligidos por um aluno seu. Texto editado e traduzido, com nota introdutória, em Manuel Barbosa, "Os clássicos e a sua leitura na pedagogia jesuítica. Os Aduersaria de Luís da Cruz, S. I (1543-1604)", Euphrosyne, 35, 2007, pp. 405-420

22 Vide n. 14. 
- Ad reg[inam] Aug[gustam]. Gratias super gratiam mulier sancta et pudorata.

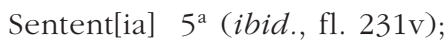

- Ad Reginam Augustam. Sicut sol oriens in altissimis Dei, sic mulieris bonae species. [Sententia sexta] (loc. cit.).

\section{Teatro:}

- Tragicomédia Prodigus. Ano de 1568:

Texto impresso: Tragicae comicaeque actiones..., cit., pp. 2-213;

Texto manuscrito: BNL, cod. 3308, pp. 800-880; BNL, cod. 3234, pp. 16-126; BGUC, cod. 1235, fls. 218r-279r.

- Tragédia Sedecias. Ano de 1570:

Texto impresso: Tragicae comicaeque actiones..., cit., pp. 443-634;

Texto manuscrito: BGUC, cod. 993, fls. 55v-102v; BGUC, cod. 1235, fls. 1-80; BPE, cod. CXIV/1-9, pp. 9-154; ANTT, Ms. da Livraria 2031; BGUC, cod. $M-M 70$, fls. $91 \mathrm{v}-95 \mathrm{v}$ (apenas o texto musicado dos coros).

- Comédia Vita-Humana. Ano de 1571 ou 1572:

Texto impresso: Tragicae comicaeque actiones..., cit., pp. 215-441;

Texto manuscrito: BGUC, cod. 993, fls. 248v-278v; BNL, cod. 3234, pp. 127-269.

- Tragicomédia Iosephus. Ano de 1564:

Texto impresso: Tragicae comicaeque actiones..., cit., pp. 829-1050;

Texto manuscrito: BGUC, cod. 993, fls. 343-388v; BGUC, cod. 1235, fls. 80159; BPE, cod. CXIV/1-9, pp. 157-320.

- Tragicomédia Manasses. Ano de 1578:

Texto impresso: Tragicae comicaeque actiones..., cit., pp. 635-828;

Manuscrito: BPE, cod. CXIV/1-9, pp. 323 e ss. (pequeno fragmento).

- Écloga Polychronius. Ano de 1592:

Texto impresso: Tragicae comicaeque actiones..., cit., pp. 1051-1117;

Texto manuscrito: BPE, cod. CVIII/2-7, fl. 136v-153v.

\section{Poemas:}

3.1 - impressos:

- "Ioanni Brigantino Antistiti Visensi longe claríssimo Actiones istas Lodoicus Crucius D. D.", in Tragicae comicaeque Actiones...cit., [p. *6];

- "Autor in has actiones ad eruditum beneuolumque lectorem" in ibid., [p. *8].

3.2 - manuscritos:

- "De Regina" (BNL, cod. 3308, pp. 472-475. 4 poemas);

- "De corona imposita Reginae" (ibid., p. 737);

- "In Mondam arenae cumulos inuehentem" (loc. cit.);

- "Ad Reginam quod humana reliquit ut aeterna consequeretur" (loc. cit.); 
- "De studio Reginae erga pauperes ad Regem Dionisium" (ibid. p. 738);

- "De bello a Regina composito inter Regem Dionysium, et Alphonsum" (loc. cit.);

- "De contemnenda gloria Reginae exemplo" (loc. cit.);

- "De pecunia diuinitus in rosas mutata" (loc. cit.);

- "Quantum Regina iuuerit Lusitaniam pietate ac uirtute" (ibid., p. 739);

- "Cur leones sustineant Reginae sepulchrum" (loc. cit.);

- "De studio Reginae in pauperes uiuo coniuge Dionysio" (loc. cit.);

- "De templo a Regina erecto" (ibid. p. 740);

- "De oleo quo salus aegrotis restituitur" (loc. cit.);

- "De caenobio a Regina condito uim temporis omnem superaturo" (loc. cit.);

- "De imagine imposita sepulchro" (loc. cit.);

- "De pace a Regina composita inter filium et patrem ode" (ibid., p. 741);

- "In patrem contra filium copias ducentem a Regina placatum ode 2a" (ibid. p.141-142);

- "In cohortes Lusitanorum mutuo pugnantes quas sedauit Regina ode $3^{\mathrm{a}}$ " (ibid. p.142)

- "Pro regno Lusitano et rege Sebastiano ad Reginam Elisabetham. Ode 4a" (ibid., p. 743);

- "Quantum innocentia exemplo Reginae prosit: quantum obsit uitium. Ode $5^{\text {a" }}$ (ibid., p. 744);

- "Quod a Regina regnum sit conseruatum" Ode 6" (loc. cit.);

- "Odae eiusdem Reginae" (ibid., p. 795);

- "Alia" (ibid., p. 795-796);

- "In Reginae sepulchrum" (ibid., p. 882);

- "De Reginae fortitudine" (ibid., p. 882-883);

- "Monda superior Eridano ostenditur" (loc. cit.);

- "Virgini Magnae Matri" (ibid. p.883-884);

- "De Regina fingendi simulachro" (ibid., p. 884);

- "De sepulchro in aede Diuae Clarae sacra" (loc. cit.);

- "Reginae loquitur imago" (loc. cit.);

- "Sepulchri lapis" (ibid., p. 885);

- "De simulachro Reginae" (loc. cit.);

- "Virgini magnae matri" (BGUC, cod. 993, fl. 103v);

- "Diuae Reginae Elisabethae" (loc. cit.);

- "Diuae Reginae Elisabethae" (ibid., fl. 104r);

- "Diuae Reginae" (loc. cit.);

- "Hymnus Diuae Reginae" (ibid., fl. 104r-v);

- "Diuae Reginae Elisabethae" (ibid., fl. 104v);

- "Diuae Elisabethae" (loc. cit.);

- "Diuae Reginae" (ibid., fl. 105r);

- "Diuae Reginae Elisabethae" (ibid., fl. 109r); 
- "Diuae Reginae Elisabethae" (loc. cit.);

- "Dicatum Deo Homini" (ibid. fl. 431r); ${ }^{23}$

- "Miracula Christi nascentis: Romae corruit templum Pacis aeternum" (loc. cit.);

- "Sol in Hispania minui perspicue uisus" (ibid., fl. 431v);

- "Oleo ex fonte Tybris fluxit" (loc. cit.);

- "Vindici et liberatori Christo" (ibid., fl. 432r);

- "Optimo praedatori Christo ex Exai 2" (loc. cit.);

- "Pacificatori Deo, et obsidi Christo" (ibid., fl. 432r-v);

- "Fortissimo generis humani defensori" (ibid., fl. 432v);

- "Pabulo generis humano Christo" (loc. cit.);

- "Virgini magnae matri et pronubae diuini conubii" (ibid., fl. 433r);

- "Vrbi non minimae, sed instar orbis maximae Bethlehemiae" (loc. cit.);

- "Ara, metaque Iustitiae Praesepe Christi" (loc. cit.);

- "Asylum humanae salutis" (ibid., fl. 433v);

- "Ad haec gentis humanae postulata, Deus iudicium da regi responsio" (ANTT, Ms. da Livraria 2209, fl. 69v);

- "Antidotum caeleste contra Mandragorae uenenum" (Ibid., fl. 70r);

- "De laudibus eloquentiae" (ibid., fls. 97r-101v).

\section{Epigramas:}

- "Epigrammata Reginae Sanctae. Anno 1568":

- "Deiparae Virginis simulachro ad impluuii ianuam appenso" (BNL, cod. 3308, p. 793);

- "De Regina eiusdem quod sequitur" (loc. cit.);

- "Aliud" (loc. cit.);

- "Aliud" (ibid., p. 794);

- "Aliud" (loc. cit.);

- "Aliud" (loc. cit.);

- "Aliud" (ibid., p. 795).

- "Epigrammata in laudem D. Elisabethae Reginae anno domini 1574":

- "Reginae Elisabethae iustae Anchorae et fundamento Reipublicae" (BGUC, cod. 993, fl. 171r);

- "Reginae Elisabethae pietati et immortali famae" (Ibid., fl. 171r-v).

- "Epigrammata in laudem Diuae Elisabethae Reginae. Anno Domini 1576":

- "Symbolum primum: Plus Religio, quam uires. Elisabetha uictrici Lusitaniae" (ibid. fl. 171v);

- "Symbolum secundum: Piis praesto numina Elisabetha posteritati ueteris Lusitaniae" (ibid. fl. 171-172r);

- "Symbolum tertium: In ualle fontes. Regina sitienti gloriam" (loc. cit.);

23 Este e os 12 poemas seguintes formam um bloco composto por ocasião das festas natalícias do ano de 1577. 
- "Symbolum quartum: Compendium gloriae. Esto qualis uis haberi. Huius Elisabetha Magistra" (ibid. Fl. 172r e 173v);

- "Symbolum quintum: fama et infamia a tergo. Dicatum Elisabethae pereunti" (ibid., fl. 173v e 173r);

- "Symbolum sextum: Virtuti et in uitae fama seruit. Excusat fama se apud Reginam" (ibid., fl. 173r);

- "Symbolum septimum: Ira ferendo tunditur. Reginae immerito exulanti" (ibid., fl. 173r);

- "Symbolum octauum: Tolerantiae cedit iniuria. A Rege Dionysio dicatum Elisabethae" (ibid., fl. 172v).

\section{Enigmas}

- "Aenigma anni 1567" (BNL, cod. 3308, p. 981);

- 1568. "Insula materia..." (ibid., p. 983);

- 1569. "Pastel" (ibid., p. 986);

- "Aenigma de farelos" (BGUC, cod. 993, fl. 121v);

- "Enigma das conservas" (ibid. fl. 175r-v);

- "Pictura" (ibid. fl. 203r);

\section{Emblemas:}

- "Ad B. P. Franciscum / Emblema / "Fuit utraque merces" (ANTT, ms. da Livraria 1963, fl. 119r.

\section{A tragédia Sedecias e humanismo jesuítico}

Pelos ecos que deixou, deu brado, na altura, a representação desta tragédia no Colégio das Artes em Coimbra, nos dia 23 e 24 de Outubro de $1570 .{ }^{24}$ Detinha a direcção daquele colégio, já desde o ano de 1555, a Companhia de Jesus que, por decisão de D. João III, sucedera, nessa função, aos Bordaleses que o haviam dirigido desde a sua criação em 1547 , por convite do rei português. ${ }^{25}$ A orientação didácticopedagógica imprimida pelos Jesuítas sofreu naturalmente uma inflexão, afastando-se do rumo seguido até então pela anterior direcção, para se conformar cada vez mais com o espírito inaciano presente nas Constituições da Companhia de Jesus.

Aprovada oficialmente pelo Papa Paulo III no ano de 1540, a Companhia de Jesus, surgira num momento crucial em que a Igreja Católica precisava urgentemente de renovação para fazer face às exigências dum tempo que lhe colocava importantes desafios sociais e culturais, a que urgia dar resposta. O movimento humanista trouxera consigo uma religiosidade mais pessoal, menos massificada mas, por isso mesmo,

\footnotetext{
${ }^{24}$ Data indicada por Frèches, op. cit., p. 304.

25 André de Gouveia, Diogo de Teive e Georges Buchanam são alguns dos nomes sonantes dessa primeira direcção do Colégio das Artes.
} 
mais exigente. A sede religiosa dos fiéis era intensa e a Igreja Católica, servida por um clero que, regra geral, denotava grandes carências de formação, não estava em condições de dar respostas satisfatórias a tais exigências. ${ }^{26} \mathrm{O}$ impulso central para uma reforma da Igreja viria a ser dado por Paulo III com a convocação do Concílio de Trento em 1545.

Surgida nesta altura, a Companhia de Jesus investirá o seu esforço de renovação da Igreja promovendo o diálogo da cultura humanista com a mensagem cristã. Na carta apostólica "Regimini militantis Ecclesiae", que oficializa a criação da Companhia, explicitam-se os fins desta como sendo "o aperfeiçoamento das almas na vida e na doutrina cristã e a propagação da fé por meio de pregações públicas, do ministério da palavra de Deus, dos Exercícios espirituais e das obras de caridade." ${ }^{27}$ Uma sólida base cultural foi desde logo encarada pelo fundador da Companhia como a bagagem indispensável a qualquer jesuíta para dar cumprimento a estes desígnios fundadores. Isto mesmo pode confirmar-se no parágrafo das Constituições relativo ao fim dos estudos: "O fim dos estudos na Companhia é ajudar, com o favor de Deus, as almas dos seus membros e as do próximo. Esta será a norma para determinar, em geral e em particular, as matérias que os nossos devem estudar, e até que ponto devem avançar nelas". ${ }^{28}$

Criados inicialmente para serviço exclusivo dos membros da Companhia e instalados na vizinhança dos grandes centros de saber, os colégios jesuítas visavam apenas apoiar e suprir a formação ministrada nesses centros de saber. Não tardaram, porém, a ver alargado o âmbito desses objectivos iniciais com a admissão de novos membros, agora já não exclusivamente noviços da Companhia, e com a constituição inclusive de um corpo docente próprio. O primeiro colégio Jesuíta a ver-se transformado deste modo em escola pública, ultrapassando os desígnios iniciais de Santo Inácio, foi o Colégio de Messina, no ano de 1548. Outros se seguiriam, comungando do mesmo espírito, acabando depois por formar-se, com o tempo, uma extensa rede de colégios sob direcção jesuítica que, em finais do séc. XVI, cobriam grande parte da Europa e se estendiam pelos territórios de missão, a saber, o Extremo Oriente e América Latina.

A progressiva elaboração dum modelo didáctico-pedagógico, característico destes colégios, inspirou-se no modus parisiensis ${ }^{29}$ tendo-se consolidado depois, progressivamente, através duma reflexão partilhada em cartas e relatórios sobre as múltiplas experiências realizadas nos mais diversos contextos. No modus parisiensis

26 Cf. Jean Delumeau, A Civilização do Renascimento, vol. I, Lisboa, Estampa, 1994, p. 136-138. Cf. Ibid., p. 103.

27 Inácio de Loyola, Constituições da Companbia de Jesus. Trad. e notas de Joaquim Mendes Abranches, S. J., Lisboa, 1975, § 1.

28 Ibid., \$ 351.

29 O modo próprio de ensinar dos colégios de Paris, depois adoptado pelos Jesuítas e adaptado à sua pedagogia. Caracterizava-se por um sentido de organização exigente, em contraste com o modus italicus. Cf. Gabriel Codima Mir, Aux sources de la pédagogie des Jésuites. Le "modus parisiensis", Roma, ARSI, 1968. 
colheram os mestres jesuítas a ideia de uma gestão rigorosa e exigente de programas e conteúdos, e de uma progressão devidamente aferida, assente numa bem avaliada assimilação dos conteúdos. A pedagogia e didáctica jesuíticas, tal como viriam a ficar consignadas na Ratio studiorum, foram o resultado dessa longa e profícua partilha de experiências levadas a cabo, ao longo de três décadas, nos mais diversos colégios. ${ }^{30}$ Essa partilha alimentou uma reflexão que conduziu a um conjunto de decisões que asseguraram ao sistema didáctico e pedagógico uma organicidade de grande eficácia funcional em domínios como a organização dos curricula, a selecção de autores e textos, os métodos didácticos a privilegiar e as atitudes pedagógicas a incentivar. Nesta pedagogia escolar, o teatro tinha um papel bem definido.

A actividade teatral surge referida na Ratio como uma excelente actividade, fortemente motivadora de aprendizagens, pelo entusiasmo que despertava nos jovens. Na impossibilidade prática de repetir amiúde as grandes representações de tragédias e comédias, aconselhava a Ratio a que se recorresse a esta actividade mesmo de forma improvisada, no contexto da sala de aula. Os alunos, sobretudo os mais adiantados, eram incentivados a integrar planos consertados de composição de peças de teatro de menor dimensão ("aeglogas", "scaenas", "dialogos") a partir dum tema dado pelo mestre. ${ }^{31}$

A tragédia Sedecias surge neste tempo de fascínio pelo teatro, mas o contexto particular da sua génese destaca-a das peças improvisadas na sala de aula. O teatro jesuítico de que se fala e de que se conhecem alguns textos é o teatro de grande aparato. Nele se integra a presente tragédia. É este um teatro de magnificência, no cenário e nos textos, que remete para grandiosos e longos espectáculos de cinco ou seis horas, ou repartidos por dois dias, como neste caso. Em causa estão ocasiões solenes, marcadas pela visita de personalidades importantes (reis, cardeais, bispos,) ou, não sendo isso, a inauguração do ano lectivo ou o seu encerramento, com distribuição solene de prémios. Pelos trabalhos e canseiras que tais produções cénicas implicavam, estas representações de aparato ficavam-se por uma periodicidade anual, regra geral. Elas testemunham a essência do teatro jesuítico, embora estejam longe de representar a totalidade desse teatro que, no ambiente improvisado da sala de aula, como já referimos, teve campo privilegiado de experiências, cujos textos, porém, não foram objecto de registo deliberado.

30 Nos 7 volumes dos Monumenta Paedagogica Societatis Iesu, ed. Ladislau Luckacs, Roma Intitutum Historicum Societatis Iesu, 1974, podemos testemunhar toda a correspondência jesuítica que serviu de base a esta partilha reflexiva prévia à elaboração da carta magna da pedagogia jesuítica, a Ratio Studiorum. Na citação futura desta obra usarei a sigla $M P$.

31 "Quoniam uero tragoediae nec ubique nec semper nec frequenter agi possunt, ne in nimiam desuetudinem abeat haec exercitatio (...), non parum expedit, ter aut quater in anno priuatim in scholis humanitatis et rhetoricae, sine scaenico ornatu, a pueris mutuo colloquentibus recitari ab ipsis compositas aeglogas, scaenas, diálogos, quorum partes ita magister disponet ac diuidet paulo prouectioribus scribendas, ut coniunctae postea unum corpus coagmentent" - MP V, p. 205 
No caso da Sedecias, o pretexto para a sua composição e representação foi a visita a Coimbra, em Outubro de 1570 , do rei D. Sebastião. Tinha o monarca então 16 anos e, pela educação que recebera, muita dela da responsabilidade dos Jesuítas, mostrava-se imbuído dum elevado misticismo, com sonhos megalómanos de engrandecimento da Fé e do Império. Daqui derivava, no aspecto prático, um fascínio incontrolável pelos exercícios militares, alimentado pela obsessão de combater os infiéis no Norte de África. Segundo a historiografia jesuítica, este entusiasmo bélico do jovem rei começou a deixar apreensivo tanto o seu confessor, o P. Luís Gonçalves da Câmara, ${ }^{32}$ como o Cardeal D. Henrique. O convite para se deslocar a Coimbra teria mesmo como objectivo desviar o espírito de D. Sebastião das questões militares. ${ }^{33}$

Esta ida a Coimbra motivou de imediato um intenso trabalho de preparação do acolhimento a dar ao rei, com toda a pompa e solenidade que naqueles tempos do Renascimento era usual conceder a monarcas, príncipes e outras altas individualidades. De dois desses momentos, ambos de índole teatral, chegaram até nós testemunhos textuais preciosos. Um deles foi a entrada do rei na cidade; o outro foi precisamente a representação da tragédia Sedecias.

A entrada de D. Sebastião na cidade foi objecto duma encenação alegórica cujos propósitos doutrinais se conjugam com um tipo de virtude política que transparece igualmente do texto da tragédia que seria representada dias depois no pátio do Colégio das Artes. Nessa encenação de boas vindas ao rei, à entrada da cidade, várias personagens de tipo alegórico recitaram discursos para o jovem monarca, do cimo de pequenos estrados dispostos ao longo do percurso. A intenção desta recepção afigura-se-nos clara: ao receber o rei em triunfo e ao dar expressão a tal triunfo na fala de várias personagens pretender-se-ia desde logo pôr em marcha um programa de moralização centrado na figura do jovem rei. Das personagens que se iam dirigindo ao monarca, umas eram alegorias como o Século de Ouro (Seculum Aureum), o Soborno, o Direito, o Luxo (Luxus), o Zelo da Fé e a Impiedade (Infidelitas); outras eram prosopopeias, como Portugal Pretérito, e os rios Nilo, Ganges e Rio de Janeiro. ${ }^{34}$

Quanto à tragédia Sedecias, é de crer que estaremos perante uma encomenda feita ao grande mestre de humanidades que era na altura Luís da Cruz, com provas já dadas no domínio da composição teatral. ${ }^{35} \mathrm{Na}$ mente dos responsáveis jesuítas haveria a convicção de que se deveria tirar o máximo partido desta visita e de que,

32 Atribuía-se a este jesuíta, com ou sem razão, responsabilidades por estes traços de carácter na personalidade do jovem rei, que lhe terão sido nocivos.

33 Francisco Rodrigues, A bistória da Companbia de Jesus na Assistência a Portugal, Porto, 1931-1944, II, 2, p. 344.

34 Cf. Manuel J. S. Barbosa, Bíblia e tradição clássica: a tragédia Sedecias do P. Luís da Cruz, S. I. na convergência duma estética e duma pedagogia. Dissertação de Doutoramento. Lisboa, Fac. de Letras, 1998, Tomo I, pp. 235-237, e pp. 317-320, estas últimas com os textos dos discursos, da autoria do Jesuíta Manuel Pimenta (1532-1603), transcritos de BGUC, cod. 993, fls. 116v-118r.

35 Luís da Cruz já compusera a tragicomédia Prodigus, em 1568, e é bem possível que, na altura, a sua fama de dramaturgo não dependesse apenas da composição desta tragicomédia, 
na sua preparação, nada deveria ser deixado ao acaso, a fim de que desta estadia do rei no Colégio das Artes resultasse um reforço do prestígio da Companhia, não só perante o rei mas igualmente perante sectores da nobreza onde esse prestígio se encontraria algo abalado. A representação teatral, habitual em tais momentos, terá sem dúvida sido cuidadosamente encarada em ordem a constituir uma resposta às circunstâncias do momento. Em carta para Roma, datada de Maio desse ano, o P. Jorge Serrão, reitor do colégio, dá conta ao Padre Geral da anunciada visita do rei e de indicações recebidas do P. Luís da Câmara para que se preparasse a representação duma tragédia. ${ }^{36}$ É de crer, pois, que o trabalho de Luís da Cruz resultou duma encomenda feita em Maio, quando se soube da ida do rei a Coimbra. Terão sido as altas instâncias jesuíticas a escolher o tema e a estabelecer as grandes linhas dum tratamento dramático que desse realce a determinados tópicos moralizadores, sugeridos essencialmente pela presença do rei, na altura ainda um adolescente de dezasseis anos. Com tais indicações, Luís da Cruz lançou-se ao trabalho e, em Setembro, já decorriam os ensaios. Seria uma tragédia de assunto bíblico tendo por tema o destino trágico de Sedecias, o último rei de Israel, tal como vem narrado sucintamente em 2 Reis 24, 18-19 e 25, 1-7 e em 2 Crónicas 36, 11-21 e, de forma mais extensa e pormenorizada, em vários capítulos do Livro de Jeremias.

A composição de dramas de tema bíblico tinha grande voga nos ambientes humanistas de então. No género tragédia, merece destaque especial o nome de Georges Buchanan que, como já referimos, integrou a equipa de mestres Bordaleses que inaugurou o Colégio das Artes em 1548. Em Bordéus, celebrizara-se com as suas tragédias de tema bíblico Jephthes e Ioannes Baptistes. Entre nós, Luís da Cruz tinha já o exemplo de Miguel Venegas, jesuíta valenciano vindo para Portugal por alturas da entrega do Colégio das Artes aos jesuítas, autor de três dramas bíblicos, as tragédias Saul (1559), Acab (1562) e Absalon (1563).

\section{A poética da Sedecias}

\section{1 - Estrutura dramática}

O enredo da tragédia Sedecias pode resumir-se como segue:

mas também de idêntico trabalho feito nos anos anteriores, designadamente em Braga, no Colégio de S. Paulo, nos anos 1564-1566, como já referimos.

36 "...Para Octubre que viene me tiene escrito el Pe. Luis Gonçalves que sin falta vendra el rey y cardinal nesta ciudade y para entonces se prepara / una tragedia y otras cosas con que esperan se holgaran muito por la afección que tienen a la compañía y conceito grande que tienen deste collegio, según me escrivio el P. Luis Gonçalves exhortando-me a que se preparasse tudo bem..." (ARSI, Lus. 64, fl. 61r-v). Um pouco mais à frente faz-se alusão ao ambiente de intrigas na corte contra o ascendente dos Câmaras sobre o rei: "...que de aqui puede nascer la murmuracion que hay en algunos que los padres que andam en la corte guvernam el reino y também porque las leis y cosas que el rey tiene hechas y ordenadas todas son para reformar la justicia y buenas costumbres..." (ibid., fl. 61v). Os Câmaras eram, além do já referido P. Luís Gonçalves da Câmara, o seu irmão Martim Gonçalves da Câmara. 
Sedecias, rei de Judá, não dando ouvidos aos repetidos e angustiados apelos do profeta Jeremias, rompe o pacto de submissão que firmara com Nabucodonosor, recusando-se a pagar-lhe o tributo anual em ouro e aliando-se ao Egipto e às nações vizinhas, a fim de poder resistir ao assédio militar do monarca assírio. Este, após derrotar o Egipto e quebrar a resistência de Jerusalém, invade a cidade, incendeia-a e chacina ou prende os seus habitantes. O rei judeu foge com os filhos, mas acaba por ser capturado e levado à presença do tirano assírio. Este, tomado de cólera, mata as duas crianças na presença do pai, arranca-lhe de seguida os olhos e fá-lo seguir depois para Babilónia, integrado no longo cortejo de cativos.

Luís da Cruz ilustrou em cena este enredo através duma acção dramática dividida em cinco actos, cada um deles agrupando um conjunto de cenas animadas por personagens cujo pensamento e actuação em palco seguem com fidelidade a fonte bíblica. A abrir a acção colocou um prólogo e fechou cada cada acto com um coro.

\section{O prólogo:}

Tal como se apresenta concebido, o prólogo da tragédia Sedecias cumpre duas funções: antecipa, por um lado, a compreensão do enredo dramático, informando sobre os antecedentes da acção e resumindo o seu desenrolar em cena até à catástrofe, e introduz, por outro, a ambiência trágica, predispondo a assistência para a catarse final. O Anjo Custódio de Jerusalém, a personagem ex-machina que faz de prólogo, dá já um verdadeiro início à acção dramática. Com o seu voo para as alturas (vv. 183-4), ele simula o abandono da cidade, deixando-a entregue a si mesma, sem protecção divina. Além disso, ao pronunciar um discurso carregado de emoção, ele evidencia já a angústia que sente pelo destino trágico de Jerusalém. Do alto da sua omnisciência, o Anjo antevê a calamidade terrível que a devastará e reage como se a presenciasse. No seu discurso perpassam já uma série de tópicos que, com recorrência notória ao longo de toda a tragédia, caracterizarão a mensagem moral desta, de teor vincadamente político, como se pode ver:

- não é a preparação da guerra que protege a pátria (vv. 100-1);

- só a piedade a pode proteger devidamente (v. 60-1; 101-2);

- Deus é o senhor do poder; só Ele dispõe dos reinos (vv. 128-9);

- Só permanece firme quem se apoia na protecção de Deus (v. 180);

- sem o auxílio de Deus, de nada valem as armas (vv. 181-2).

Estamos aqui perante um prólogo plenamente articulado com a acção dramática, bem ao contrário do que acontecia com os prólogos das comédias, onde o poeta não deixava de falar em nome pessoal. Neste caso, o prólogo faz-nos aceder à fábula e contribui para a solidez desta, como propunha a teoria poética. ${ }^{37}$

37 Prologus est tragoediae principium, cui datae sunt partes fabulam aperiendi, in quo praeteritae actiones enuntiantur, et ad reliquam fabulam aditus, et munimen instruitur" - Ioannis Antonii Viperani De poetica libri tres, Antuerpiae, ex. officina Christophori Plantini, M.D.LXXIX, 


\section{A divisão em actos:}

A distribuição da matéria trágica pelos cinco actos obedece a uma transposição de dados bíblicos para a estrutura dramática, sem grande esforço de tratamento poético de tais dados, no sentido da concentração de tempos e lugares, como propunha cada vez mais a exegese que se ia fazendo da poética aristotélica. Em alguns casos, um acto corresponde a um capítulo do Livro de Jeremias, como pode ver-se:

- acto I: apelos de Jeremias à submissão a Babilónia (Jr 27);

- acto II: conflito entre Jeremias e o falso profeta Ananias (Jr 29);

- acto III: oráculos dos dois cestos de figos e da bilha de barro, prisão de Jeremias e primeiro cerco a Jerusalém (Jr caps. 19, 20, 24 e 37);

- acto IV: derrota do Egipto, regresso de Nabucodonosor, segundo cerco a Jerusalém, apelos à deserção da parte de Jeremias, prisão e lançamento deste na cisterna ( $\mathrm{Jr} 38)$;

- acto V: Jeremias retirado da cisterna, assalto final à cidade, prisão e suplício de Sedecias e de seus filhos (Jr caps. 38-39).

Sabemos, por testemunho do próprio dramaturgo, que a peça foi representada em dois dias, com os três primeiros actos constituindo o primeiro bloco da representação. Nesse bloco, Jeremias assume o papel mais preponderante, com seus alertas insistentes sobre a desgraça que ameaça a cidade de Jerusalém. O segundo bloco, com uma acção cénica mais animada, destaca-se sobretudo pela presença das tropas assírias e pelas movimentações militares de ambos os lados, até à destruição da cidade, com a capitulação do exército sitiado e a humilhação brutal do rei judeu às mãos de Nabucodonosor.

Os acontecimentos implicados na acção destes cinco actos remetem para uma duração real de cerca de sete anos, já que, de acordo com a fonte bíblica, a vinda dos embaixadores a Jerusalém (acto I) ocorre no quarto ano do reinado de Sedecias ( $\mathrm{Jr} 28,1)$ e a tomada de Jerusalém no "quarto mês do décimo primeiro ano" ( Jr 52, 6). O dramaturgo, sem se preocupar com o conceito de unidade de tempo que faria escola no classicismo do séc. XVII, ter-se-á preocupado em instaurar essa ideia no interior de cada acto, mediante certas indicações favoráveis à ilusão da concentração dos acontecimentos. Assim, no acto II, Jeremias anuncia a Ananias que ele morrerá nesse ano (vv. 1083-85); no acto III, cena 1, vv. 1644-9, o profeta garante que não terminará o dia sem anunciar à corte as terríveis ordens de Deus. No acto V, cena 9, vv. 3564-70, Nabucodonosor garante arrasar Jerusalém antes do pôr do sol.

p. 102 ("O prólogo é o início da tragédia. A sua função é a de revelar o enredo. Nele se enunciam os acontecimentos passados e se prepara o acesso ao resto do enredo, bem como o reforço deste."). Giovanni Antonio Viperano, um dos primeiros jesuítas, foi mestre de humanidades e retórica no Colégio de Messina. Pensa-se que terá composto aí o seu tratado de poética. Viria a abandonar a Companhia, terminando como Bispo de Giovinazzo. Cf. E. Springhetti, S. I., "Un grande umanista Messinese: Giovanni António Vioperano. Cenni biografici", Helicon, I (1961), 94-117. 
Parece-nos, pois, razoável concluir que Luís da Cruz, na estruturação da acção, procedeu de forma a criar a ilusão do seu avanço por jornadas, pelo menos nos actos III e V. Este avanço da acção ilustra, em cada acto, uma economia narrativa que segue os ditames da reflexão poética que por esses tempos sustentava a prática dramatúrgica. A função do primeiro acto será a de fornecer "uma breve explicação da situação" (o rei judeu alia-se com as nações vizinhas e, quanto a uma opção bélica, balança entre os vaticínios opostos dos profetas); o segundo acto "dá início à acção", com a opção em definitivo pela guerra, seguida da morte, inesperada e premonitória, do falso profeta Ananias; o terceiro acto "evidencia os perigos" com a chegada das tropas assírias e posterior retirada, semeando medo e inquietação no espírito do rei e de seus súbditos; no quarto acto, "torna-se inequívoco o rumo dos acontecimentos": Nabucodonosor regressa e monta um cerco implacável à cidade; no quinto, "narram-se as desgraças acontecidas e dá-se um fim lastimoso à acção": 38 Jerusalém é conquistada pelas armas e entregue às chamas, Sedecias é aprisionado e supliciado, vendo os filhos massacrados na sua presença, seguindo depois, já sem olhos, para o exílio em Babilónia, integrado no cortejo dos seus compatriotas, igualmente cativos.

As cenas de que se compõem os actos apresentam-se com uma tipologia mais ou menos recorrente: cenas de contexto palaciano, cenas com o oráculo e cenas com a presença exclusiva de Jeremias e do moço. As cenas de contexto palaciano afiguram-se fundamentais pelos animados debates a que dão azo. A recorrência de pontos doutrinais, com as questões da guerra e da idolatria mais em realce, e o comportamento dos vários intervenientes, num antagonismo bem marcado pela posição isolada de Jeremias frente ao rei e aos nobres, permitem entrever facilmente as intenções que moveram o poeta. As cenas do Oráculo, em que Jeremias recebe as ordens divinas, plenas de intensidade patética, preparam e legitimam as posteriores intervenções do profeta perante o rei e os nobres. As cenas exclusivas do Moço e de Jeremias situam-se geralmente no início de cada acto ou entre as cenas do Oráculo e as de contexto palaciano. Na economia narrativa, elas apoiam com verosimilhança o avanço da acção dramática, segundo uma sintaxe de progressão continuada, sem transições bruscas.

$\mathrm{Na}$ criação destas cenas, o dramaturgo mostra-se fiel à verdade das páginas sagradas. As cenas que mais notoriamente patenteiam uma correspondência com a fonte bíblica, decalcando fielmente os seus tópicos, são as do Oráculo. Nas outras, o dramaturgo, com base em poucos versículos, procedeu a um trabalho notável de amplificação, elaborando em alguns casos cenas bem extensas, como a cena 6 do

38 O texto entre aspas é a tradução das partes sublinhadas do seguinte excerto: "Et ut cuiusque actus uim sigillatim notemus, primus habet totius rei breuem explicationem; (...) secundus initium fabulae aperit, quanquam et primus quandoque id facit. Tertius pericula demonstrat. Quartus quo res uergant declarat, uel aliquando calamitatem affert. Quintus aut nuntiat mala quae euenerunt, aut fabulam miserabili fine concludit. " - Viperanus, op. cit., pp. 109-110. 
acto I, de duzentos e trinta e um versos, onde o rei enaltece a guerra, ou a última do acto V, com cerca de duzentos versos, onde se ilustra, com horror inspirado nos procedimentos de Séneca, a humilhação de Sedecias pelo tirano assírio. As cenas de Jeremias e do Moço justificam-se com base em informação dimanada do texto bíblico. Sabe-se que Jeremias tinha um secretário, chamado Baruc, cuja acção vem referida em Jr 51, 59. Finalmente temos as cenas que sustentam a sua pertinência no grau de verosimilhança que guardam com a natureza dos acontecimentos narrados, como é o caso das cenas com espiões e mensageiros, decorrentes do clima de guerra que caracteriza fortemente o enredo da tragédia.

Os coros

Após cada acto, o dramaturgo colocou coros ao estilo de Séneca, ou seja, de cunho moralizador mas sem perderem de todo a articulação com a acção narrada no acto precedente. Os motivos caracterizadores da mensagem de cada coro ilustram claramente essa articulação. No coro I, tecem-se considerações sobre o uso do poder, alertando contra falsos profetas e aduladores; no coro II, que assume a forma dum cortejo fúnebre onde se lamenta a morte de Ananias, fala-se do mal irreparável que é uma morte coberta de infâmia, após uma vida de desonra; no coro III, o tema da estabilidade do poder alimenta um discurso estruturado sobre os motivos antitéticos do equilíbrio e da queda, da estabilidade e da derrocada; o coro IV, iniciado com um convite ao pranto, soa já como uma alusão à catástrofe que ocorrerá no acto seguinte, resultante duma situação instalada de criminalidade desenfreada, evidenciada numa série de comportamentos monstruosos ("haec monstra" - v. 3244) aceites por todos; o coro V, após a catástrofe, sustenta o seu discurso no motivo do choro, bem patente na recorrência do refrão, onde pontuam as interjeições de dor ("heu!", "eheu!"). Dando fim à acção dramática, ele configura uma saída de cena, ilustrada no triste cortejo de cativos judeus, acompanhados de seu rei, a caminho de Babilónia. Este último coro parece denotar, na sua concepção, o propósito do dramaturgo de reassumir e vincar as linhas de força do discurso moralizador expendido ao longo da tragédia. A imitação dos lamentos de quem chora, carregando a servidão anunciada, associa-se à mensagem dos coros II e IV. Por outro lado, a moralização política que perpassa nesses lamentos, tanto de Jeremias como dos cativos, reenvia para os coros I e III. O rei Sedecias é apontado como o exemplo de quem não soube utilizar o poder por ter faltado aos compromissos assumidos, por ter violado as leis de Deus e ter confiado cegamente na guerra (vv. 4008-11; 4014-4017). Com o mau exemplo deste rei, deverão aprender os demais ("ex te discat..." - v. 4028).

\section{A métrica dos versos:}

Como transparece claramente dos seus prefácios poéticos, a métrica dos versos foi questão assumida com muito zelo pelo dramaturgo. Sinal disso é a forma como ele gasta tempo a justificar, pensando nos eventuais reparos dos críticos do seu tempo, a estrutura dos senários jâmbicos em que dialogam as personagens dos seus 
dramas. Séneca é o modelo a que Luís da Cruz recorre, dele recolhendo exemplos com que pretende refutar acusações relativas à imperfeição de alguns jâmbicos, como, por exemplo, os que "manquejariam" no quinto pé. ${ }^{39}$ Este apego ao modelo Séneca transparece igualmente nos demais tipos de versos que compõem a ratio metrica da tragédia. Eles distribuem-se pelos cinco coros e por um conjunto de outras situações dramáticas diferentes das de mero diálogo, como momentos de profecia, de súplicas a Deus, de proclamações solenes e de exortações à guerra. Para este conjunto de situações acabadas de referir, conotadas todas elas com um certo heroísmo, o dramaturgo destinou o metro heróico, a saber, o hexâmetro dactílico. ${ }^{40}$

Apresentamos de seguida em quadro, segundo o desenrolar dramático, a distribuição dos vários tipos de versos da tragédia, com exclusão dos já referidos senários jâmbicos:

\section{I, 3 (299-302; 306-310; $320-327 ; 330-333 ; 336-$ $357)^{41}$}

Coro I (795-851)

II, 2 (928-936; 973-981)

II, 3 (1003-1005; $1012-$ 1023)

II, 5 (1230-1261)

II, 6 (1294-1314)

Coro II (1503-1534)

III, 1 (1559, 1565-1583;

1592-1596; 1602-1610;

1614-1618; 1620-1622;

$1627-1633$; 1639-1642

III, 5 (2118-2120)

III, 6 (2132-2138; 21392143)
Profecia. Fala do Oráculo

Profecia. Fala do falso profeta Ananias

Profecia. Fala do Oráculo

Oráculo do falso profeta

Proclamação do tribuno da milícia

Funeral de Ananias

Profecia do Oráculo

Instruções militares

Proclamação do arauto assírio.

Resposta das sentinelas de Judá
Asclepiadeus

Hexâmetros dactílicos

Hexâmetros dactílicos

Hexâmetros dactílicos

Tetrâmetros trocaicos catalécticos

Hexâmetros dactílicos

Endecassílabos sáficos Hexâmetros dactílicos

Hexâmetros dactílicos

Hexâmetros dactílicos

39 Defendiam os exegetas de Séneca que na quinta posição o senário jâmbico não devia admitir um jambo (sílaba breve + sílaba longa), pois isso deixava o verso coxo ("claudicans"). Sobre esta e outras questões de justificação da métrica utilizada no seu teatro, cf. Manuel Barbosa, "Luís da Cruz e a poética teatral», cit., pp. 375-405

40 Os Hexâmetros dactílicos da Sedecias associam-se geralmente à expressão de profecias, procedimento usual em Séneca, como se pode verificar em Oed., vv. 233-238, onde Creonte reproduz uma profecia da pitonisa de Delfos.

${ }^{41}$ Em romano, surge indicado o acto; em árabe, a cena e entre parêntesis os respectivos versos. 
III, 8 (2236; 2241-2247)

III, 9 (2289-2294; 2295 2296)

Coro III (2297-2348)

IV, 4 (2622-2645)

IV, 8 (2852-2861; 28662889; 2891-2895)

IV, 11 (2974-2981)

IV, 12 (2982-2990; 29912993)

IV, 13 (3090-3094)

IV, 14 (3159-3166)

IV, 15 (3219-3228)

Coro IV (3234-3285)

V, 2 (3359-3367)

V, 3 (3399-3403; 34063407)

V, 13 (3920-3929)

Coro V (3969-3989; 39984003; 4014-4019; 4021-4035)

Coro V (3990-3997; 40044013)

Coro V (4020; 4036)
Clamor dos sitiados

Proclamação do arauto e

resposta do exército

Anapestos c/ adónio

Jeremias eleva preces a Deus

Profecia. Fala do Oráculo

Proclamação do arauto e

resposta dos soldados

Intimação de Nabuzardano.

Resposta dos sitiados

Profecia de Jeremias

Profecia de Jeremias

Súplicas de Jeremias

Súplicas de Jeremias

Exortações militares

Lamento de Sedecias sobre os cadáveres dos filhos

\author{
Lamentações de Jeremias
}

final (2348)

Hexâmetros dactílicos

Hexâmetros dactílicos

Hexâmetros dactílicos

Hexâmetros dactílicos

Hexâmetros dactílicos

Hexâmetros dactílicos

Hexâmetros dactílicos

Hexâmetros dactílicos

Hexâmetros dactílicos

Asclepiadeus

Hexâmetros dactílicos

Hexâmetros dactílicos

Hexâmetros dactílicos

Anapestos

Hexâmetros dactílicos

\section{2 - O pensamento da fábula}

A fábula bíblica vertida para a estrutura dramática mereceu do dramaturgo um labor poético de amplificação mediante a elaboração dum discurso dinamizado por um conjunto de motivos que a singularizaram como artefacto poético.

\section{- Motivos bíblicos:}

- a idolatria: é um dos tópicos fortes do prólogo e recorre igualmente ao longo da tragédia. Surge apresentada como uma traição à Aliança firmada por Deus com o seu povo no monte Sinai, após a gesta do Êxodo. O povo eleito sofre de falta de memória. Depressa esquece os benefícios recebidos de Javé, seu único Deus, e volta-se para deuses estrangeiros, adorando imagens de pedra ou de madeira, como 
no caso do culto a Baal. A própria Jerusalém surge descrita como cidade adúltera, pelo rompimento da Aliança estabelecida com Javé, por via da idolatria.

- a cólera de Deus: o motivo da cólera divina e dum castigo de proporções assustadoras advindo da explosão dessa cólera transparece geralmente nas falas do Oráculo ou nas intervenções de Jeremias perante o rei e os nobres. "furor", "indignatio", "iracundia", "ira" são termos de grande recorrência que, isolados ou em sintagmas, dão expressão adequada a essa cólera intensa do Deus do Antigo Testamento, bem explícita, aliás, em vários passos do Livro de Jeremias, como o seguinte:

- Et conflata est indignatio mea et furor meus, et succensa est in ciuitatibus Iuda " - Jr 44,6 (trad. : “...e a minha indignação e a minha fúria incendiaram-se e espalharam suas chamas pelas cidades de Judá”. $)^{42}$

- a intensidade do castigo: surge apresentada na proporção directa do grau da cólera. O dramaturgo transpôs para o discurso da tragédia vários tópicos bíblicos referentes a uma intensidade assustadora do castigo: este virá como uma tempestade, sugestiva duma descarga emocional de Deus que, desse modo, apaziguará a sua cólera ( Jr 30, 23-24). Os flagelos da fome, da peste e da guerra devastarão profundamente a cidade $(\mathrm{Jr} 14,12)$. O choro de Jerusalém, condenada à servidão e ao exílio, confrontar-se-á com a chacota e o pasmo das nações vizinhas (Jr 19, 8).

- Jeremias, o profeta da desgraça: nesta personagem fez o dramaturgo convergir a riqueza de contrastes que, na fonte bíblica, compõem o carácter do profeta, oscilante entre dois pólos: por um lado, profunda compaixão pelo seu povo, cuja sorte lastima; por outro, grande firmeza e ardor na denúncia do crime e do consequente castigo, ainda que isso lhe valha a incompreensão e a chacota do povo:

"Et factus est mihi sermo domini in opprobrium et in derisum tota die" - Jr 20, 8.

(trad. : "e a palavra do Senhor tornou-se para mim causa de vexame e de chacota")

Embora fisicamente débil, devido à sua velhice (aspecto pouco realçado na fonte bíblica), na hora de profetizar ressurge, possuído de ardor profético, para proclamar com violência irresistível a mensagem divina. Tal como Deus, também Jeremias arde em ira.

"Idcirco furore Domini plenus sum" - Jr 6, 11. (trad. : " por isso estou possuído da cólera do Senhor")

- Nabucodonosor, o flagelo da ira: a caracterização do monarca assírio condiz perfeitamente com o perfil que lhe vem traçado no Livro de Jeremias: um flagelo vindo do norte para semear a desolação em Judá:

"Quia malum ego adduco ab aquilone, et contritionem magnam" - Jr 4, 6 (trad.: "...porque eu faço vir do norte desgraças e grandes destruições").

O Assírio surge como a "vergasta de Deus" (“...Assyrias tibi / Tuisque uirgas - v. 1447-8: "vergastas assírias, para ti e para os teus"), com a odiosa missão de executar sem contemplações o duro castigo decretado por Deus. Legitimado como está,

42 Tal como este, as demais citações da Bíblia seguem o texto latino da Vulgata. 
assumirá sua função de carrasco com especial zelo, recorrendo a uma crueldade sem limites, no descarregar de toda a ira divina. Na caracterização desta vergasta assíria, o modelo Séneca brilhou a grande altura.

\section{- O pathos:}

Dos motivos responsáveis pela criação duma atmosfera trágica, destacam-se sobretudo os seguintes:

- o horror ao crime: Substantivos como "scelus", "crimen" e "facinus" superabundam no discurso da Sedecias, com um tipo de qualificação que vive de adjectivos como "immanis", "infandus", "horrendus", entre outros, alusivos ao carácter monstruoso dos crimes. O perfil psicológico dos criminosos surge igualmente realçado por uma profusão de adjectivos, de que se destacam, entre os mais recorrentes, "impius", "superbus", "perfidus" e "ingratus". A obsessão pelo crime apoderou-se de todos, como se as Fúrias infernais se tivessem alojado nos seus espíritos (vv. 866-8). Adjectivos como "insanus" e "praeceps" aludem a essa cegueira louca, autêntica insanidade mental que precipita desenfreadamente toda a sociedade para o crime, num completo descontrolo:

"talis furor... Omnes habena et nulla praecipites tenet " - vv. 2807-9

(trad. : "tal loucura... mantém todos cegos, sem qualquer controlo".)

- a cólera divina: "Vltor" ("= justiceiro") é o qualificativo por excelência do Deus veterotestamentário, a par do epíteto "Tonans" ("Tonante"), próprio de Júpiter nos textos clássicos. Adjectivos como "feruidus", "incensus", "efferus" e "tumens" traduzem a grandeza dessa cólera fervente, já refreada em demasia.

- o castigo implacável: Deus sabe adequar a recompensa aos méritos e o castigo à natureza dos crimes (vv. 3003-5). O castigo pode tardar mas não falha (v. 3100) e, neste caso, será bem duro, na proporção directa da enormidade do crime. Adjectivos de forte recorrência como "grauis", "durus", "saeuus" e "acerbus" aludem a essa dureza. À iminência do terrível castigo associa-se a imagem do relâmpago, várias vezes presente no discurso, em termos como "fulmen", "fulgur", "fulminare". Jeremias é acusado de anunciar tempestades que desabam do céu ("per te procella uasta de caelo ruit": v. 1964); Nabucodonosor ameaça com uma tempestade de sangue (“...procellam caede populante omnia”: v. 2177); o Oráculo compara o ímpeto destruidor do Assírio a uma chuva de ferro ("ferreus imber" - v. 2878), ou a uma rocha desprendida do cimo dum monte que tudo esmaga na sua frente (vv. 2881-2).

- a calamidade ("clades"): abater-se-á sobre o povo, traduzida nos flagelos da guerra, do fogo, da fome e da peste, outros tantos tópicos responsáveis por forte ampliação discursiva. Desses flagelos derivará muito luto, muita tristeza, muita dor e pranto, motivos que, presentes ao longo de toda a tragédia, apontam para a culminância do pathos trágico no acto V. Esse momento culminante da catástrofe vai sendo anunciado de forma gradual, numa intensificação progressiva. 
- o ethos:

Aos motivos atrás expostos acrescem os de ordem ética, factores de ampliação discursiva igualmente verosímil em relação à matriz bíblica. A par com um processo de intensificação patética, o dramaturgo pôs igualmente em marcha um outro, de moralização, que na fábula assume ora um carácter genérico, ora um carácter particular; umas vezes dirigindo-se aos habitantes de Jerusalém em geral, outras vezes privilegiando o rei judeu como principal destinatário.

- a fidelidade aos compromissos: a recorrência forte do termo "fides" «3 é, só por si, suficiente para ilustrar esta linha estruturante do enredo. Tanto Deus como Nabucodonosor sentem-se lesados na "fides" ("boa-fé", "lealdade") que lhes era devida. Deus, por ver o seu povo entregue à idolatria, quebrando a aliança firmada no monte Sinai; Nabucodonosor, por Sedecias se ter recusado a pagar-lhe o tributo anual em ouro, como ficara acordado, e se ter aliado ao Egipto. É esta traição que ele vem castigar ("perfidiam ulturus" - v. 2134).

- a prática da justiça: Judá é uma sociedade desconcertada, onde o direito se acha subvertido por culpa de quem detém o poder. O crime não é punido, mas protegido por leis funestas, propositadamente criadas. E não funcionando a justiça (v. 2042), as causas dos mais fracos são abafadas pela arrogância dos mais fortes (vv. 3241-2).

- a inutilidade da guerra: eis uma das ideias mais vincadas no discurso da tragédia, e compreensivelmente, já que o nó de acontecimentos que sustenta o enredo obtém o seu desenlace com a guerra. Até lá, as intervenções de Jeremias vão no sentido de dissuadir o rei da opção bélica, relativizando-se várias vezes no discurso a fé cega no poder das armas. Isto sucede logo no prólogo (vv. 99-101), onde se contrapõe a falsa segurança advinda da guerra à verdadeira, baseada na fé em Deus. Esta ideia é uma das mais estruturantes do discurso trágico, assomando nele várias vezes e recebendo confirmação no desfecho trágico, através da fala de Jeremias no coro V.

- o modelo moral do príncipe: é possível isolar nas falas de várias personagens um conjunto de sentenças que, pela sua natureza, ajudam a compor um perfil ideal de soberano. Este é alguém que sabe aconselhar-se, rodeando-se de bons conselheiros; alguém que se esforça por perscrutar os desígnios divinos; que promove o bem comum, que revela e infunde coragem, não temendo a guerra nem fraquejando diante dos próprios receios; alguém de conduta moral irrepreensível, vigilante e zeloso no combate ao crime, pronto a confortar os inocentes e a revelar-se indulgente com os vencidos. A estabilidade do poder depende muito da estatura moral dos reis, como adverte o coro III.

- a precaridade do poder: só Deus é o dono do poder, podendo entronizar ou depor reis ("fas mihi regna dare, et solio deponere reges" - v. 341). Nenhum rei deverá considerar-se seguro em seu trono, abusando da sua posição. As injustiças e

43 Ocorre trinta vezes. Este dado e outros semelhantes utilizados nesta "Introdução" apoiamse no sistema de concordâncias a que submetemos o texto da Sedecias. 
as infidelidades minam a solidez do poder. Onde é nula a preocupação pelo direito, onde não reina a boa-fé, o poder oscila e cai (vv. 3724-5).

- o veneno da lisonja: o séquito de conselheiros que rodeia Sedecias é várias vezes alvo dum discurso que lhes estigmatiza as atitudes de hipocrisia aduladora. Tais pessoas são descritas como sepulcros caiados de branco, repletos de podridão interior (vv. 554-9), corruptos, com atitudes estudadas quando exteriorizam mágoas, invocam Deus e presumem falar sob inspiração divina (vv. 796-808). São perigosíssimos com seus discursos suaves, de palavras melífluas, que corrompem quem os escuta (v. 820).

\section{3 - A elaboração discursiva (ou elocutio)}

Demos conta, sucintamente, dos principais tópicos do discurso trágico presentes nas falas das diversas personagens. Na elaboração desse discurso, o dramaturgo procedeu certamente de forma a nunca ultrapassar os limites do decoro exigido pela condição e situação de cada personagem, como preceituava Aristóteles (Poet., $\$ 1455^{\mathrm{a}}$ ). O discurso da tragédia Sedecias apresenta-se, naturalmente, com um estilo elevado, servido por uma série de recursos estilísticos, entre tropos e figuras, que o dramaturgo, com a boa formação retórica que possuía, manejou com facilidade, em ordem a obter os efeitos pretendidos de sublimidade, grandiosidade e veemência. Dos tropos, há a salientar sobretudo a perífrase, a hipérbole e a comparação, esta muitas vezes na forma do clássico símile.

O uso da perífrase destaca-se muito na alusão a realidades cósmicas, como o mostram os seguintes casos, em que os dois primeiros aludem ao céu e o último ao curso do sol:

- "Ab arce nitidi rector astrifera poli" - v. 666;

- "De sede regni fulgidi aetheria" - v. 747;

- "Bis duodena suo cum circumuoluerit astra / Flammifer in curru Titan..." - vv. 928-29

A hipérbole, por seu lado, parece evidenciar-se sobretudo na acentuação do carácter terrível dos flagelos da guerra, da peste e da fome, enquanto factores de mortandade. Nos dois exemplos seguintes, o primeiro põe em realce o grau sangrento da chacina praticada pelas tropas assírias, enquanto o segundo alude à elevada mortandade que, nas palavras do Oráculo, ameaça o reino de Judá:

- "Et gladio Assyrii rubeant late arua tyranni" - v. 357

- "strata cateruatim ducentur corpora uulgo / et breuiter summos aequabunt funera montes" - 1607-8

A comparação, sobretudo na modalidade mais extensa do símile, constitui no discurso poético da tragédia um notável testemunho da criatividade poética do dramaturgo. Em alguns casos, este terá retomado símiles já bem conhecidos na literatura clássica, adaptando-os ao enredo da Sedecias. O caso mais notório parecenos ser o do símile que utiliza a imagem da raiva do leão esfaimado dilacerando 
vitelos descontroladamente como símbolo quer da cólera incontida de Deus face aos crimes do seu povo (vv. 1664-69), quer da fúria dos soldados assírios em pleno combate, incapazes de se deterem na chacina continuada dos inimigos (vv. 3483-90):

- "Qualis Armeniae leo / In nemore denso impastus ad praedam ruit / Praedaeque rictus sanguine uoraces lauat, / Non aliter ille conditor Olympi aurei, / Ob scelera nostrae gentis, irarum calet / Flammatus aestu." - vv. 1664-69;

- "Vicina magno qualis Euphrati iuga / Leo colit asper, quem sacra armentum fames / Laniare cogit, ungue cum tauros ferox / Euiscerauit, uentre iam pasto satur / Libido nondum cessat, et plures sibi / Vitulos minaci dente mactari iubet, / Ita caede fessus plurima miles furit, / Adhuc calentem pectoribus iram tenet." - vv. 3484-90

Neste caso, achamos que o Tiestes de Séneca constituiu a principal fonte de inspiração, não sendo de excluir igualmente outra influência contaminadora, ainda que mais remota, advinda da Eneida de Virgílio. ${ }^{44} \mathrm{Na}$ maioria dos casos, porém, a criatividade de Luís da Cruz não se terá deixado condicionar por uma imitatio muito circunscrita a passos concretos da literatura latina. Serão certamente de herança clássica certos símiles assentes em factos da vida humana, animal ou vegetal: as madrastas como símbolo de ódio (v. 3954), os tigres como símbolo de crueldade (v. 1957), a corça assustadiça como ilustração dos efeitos do receio infundado (vv. 2722-25), ou as papoilas no tocante à fragilidade extrema (vv. 121.122). Mas noutros casos, o dramaturgo não se terá eximido a uma completa originalidade na evocação de imagens simbólicas ilustrativas de determinadas situações do enredo da Sedecias. Pode bem ter sido o caso de alguns sugestivos símiles, como o que compara toda a agitação bélica em que fervilhava a cidade de Babilónia com o crepitar característico duma pira em chamas erguida com folhas verdes de loureiro (vv. 1820-23); ou então, para só citar mais um exemplo, o que compara o avanço das tropas assírias com um incêndio devorando a floresta (v. 2959).

O aspecto da veemência discursiva sobressai essencialmente na administração de determinadas figuras. Destas, destacamos a interrogação, muitas vezes em acumulação crescente; a apóstrofe, nos casos em que se invocam deuses ou potências cósmicas, ao serviço de sentimentos de indignação, revolta e ameaça; a interjeição, com intenções abominativas, de horror ao crime; a enumeração, muito frequente, cuja funcionalidade mais em evidência no discurso trágico parece ser a de realçar a criminalidade desenfreada ou o castigo que atingirá os provocadores.

44 Sen., Thyest., vv. 732-740: "Silua iubatus qualis Armenia leo / in caede multa uictor armento incubat / cruore rictus madidus et pulsa fame / non ponit iras: hinc et hinc tauros premens / uitulis minatur dente iam lasso pigar, / non aliter Atreus saeuit atque ira tumet / ferrumque gemina carde perfusum tenens, oblitus in quem fureret, infesta manu / exegit ultra corpus...".

Virg., Aen. 339-343: "Impastus ceu plena leo per ouilia turbans / (suadet enim uesana fames) manditque trahitque / molle pecus mutumque metu, fremit ore cruento. / Nec minor Euryali caedes; incensus et ipse / perfurit ac multam in medio sine nomine plebem". 


\section{4 - O modelo Séneca}

$\mathrm{Na}$ construção deste discurso, Séneca foi o modelo mais actuante. Isso é notório a vários níveis: nos empréstimos textuais, em tópicos como o jogo cruel da fortuna, a ilusão do poder e a sua precariedade e no gosto pela sentença. Este aflora bastante no discurso, algumas vezes pelo método da antítese frásica, ilustrando comportamentos que oscilam entre atitudes contrastantes, como, por exemplo, clemência versus rigor, nos vv. 3635-3660.

Mas além deste e doutros aspectos típicos do discurso de Séneca já evocados, merece aqui menção especial o decalque de cenas do seu teatro, em ordem à construção de algumas cenas da Sedecias. É o caso dos discursos eufóricos de Nabucodonosor, pela tomada de Jerusalém (vv. 3550 e ss.) e, mais tarde, de Nabuzardano, pela captura do rei judeu (vv. 3689-3696), que retomam, em certa medida, os vv. 885-919 do Tiestes, onde Atreu dá largas ao seu contentamento pela vingança levada a cabo sobre o irmão, a quem fizera comer os próprios filhos, sem o saber.

Além do Tiestes, outras tragédias do cordovês inspiraram o labor poético de Luís da Cruz, como o Édipo e a Medeia. Isto é inequivocamente evidente na cena final da Sedecias, onde se dá ênfase especial a processos de horror típicos do tragediógrafo latino, neste caso aplicados à situação trágica do rei judeu, com base nas tragédias acima referidas. Sedecias surge nesta cena cruelmente dilacerado por uma angústia e sofrimento afins aos de Tiestes e de Édipo nas tragédias homónimas de Séneca, e aos de Jasão, na Medeia. Nabucodonosor, ao invés, assume os aspectos da fúria e da crueldade de Atreu e de Medeia. Evoca Atreu na forma enigmática como vai desvendando gradualmente os seus sinistros propósitos. Saciará o pérfido pai com a morte dos filhos (v. 3697); o rei judeu nem faz ideia a que mãos veio parar (3728); exulta com o desespero deste ao contemplar os corpos mutilados dos dois filhos e, perante apelo igual aos de Jasão a Medeia, para que lhe poupe o segundo filho, não cede e, como Atreu e Medeia, ainda acha pouco ("minora feci" - v. 3930). ${ }^{45}$ Tal como eles, compraz-se em saborear a vingança sem pressas, velando para que o rei judeu recobre a consciência plena, após um desmaio por excesso de sofrimento. ${ }^{46}$

Os pontos de contacto com Rei Édipo, nesta cena final, giram em torno da ideia de castigar um crime pouco usual. Na tragédia de Séneca, é a própria vítima trágica que pondera o castigo que deverá infligir a sí própria, afigurando-se-lhe a morte como castigo insuficiente. ${ }^{47} \mathrm{O}$ mesmo pensa Nabucodonosor, mas em relação a Sedecias, acabando por, em sentença enigmática decalcada de Séneca, aludir ao castigo que lhe infligirá, arrancando-lhe os olhos: "Cai vivo num novo tipo de morte" - vv. 3946-7.48

45 Na tragédia de Séneca, Medeia ainda diz a Jasão que se estivesse grávida dum terceiro filho o mataria com um punhal no próprio ventre (Med., vv. 1009-13).

${ }^{46}$ Cf. Ibid., 1016-7, e Thyest. 900-1.

${ }^{47}$ Cf. Oed. 936-8.

48 Cf. Ibid., vv. 949-51. 


\section{5 - O espectáculo}

Segundo Aristóteles, esta componente da tragédia, sendo embora a mais envolvente e emocionante, não lhe é essencial, pois os seus objectivos podem igualmente atingir-se pela mera leitura. O espectáculo não produz as emoções próprias da tragédia; apenas os intensifica. ${ }^{49}$

Os vários testemunhos que até nós chegaram da representação da Sedecias são, no geral, unânimes quanto ao grande sucesso e à forte impressão que o evento deixou nos espectadores (alunos, familiares destes, quase toda a nobreza do reino e dignitários eclesiásticos que na altura acompanhavam D. Sebastião). O próprio Luís da Cruz se refere ao sucesso que foi a representação, admitindo, com modéstia de autor, que "tal aconteceu mais devido à variedade dos episódios e ao aparato de cena, bem como à elegância dos actores, do que à relativa qualidade do poema e da declamação." 50

Realmente, o tema da tragédia e a variedade de episódios que comporta, a par com uma multiplicidade de personagens, coadunam-se com a qualidade dum espectáculo de gosto barroco, assente numa carga impressiva de variados efeitos sensoriais derivados do cenário, das luzes e sons, e da riqueza de indumentária, esta assente na condição das personagens e da respectiva movimentação em cena. Tal espectáculo, saturado de tantos ingredientes extra-textuais, parece ter ficado bem vivo na memória dos espectadores e ter sido tema de conversa por algum tempo. Será a este espectáculo barroco que se refere Luís da Cruz no prefácio da sua comédia Vita Humana, ao designar esta de "módica ceiazinha", em comparação com o "festim trágico" de dois dias que foi a Sedecias. ${ }^{51}$

Passemos então em revista os principais ingredientes do espectáculo que foi a representação desta tragédia.

- o cenário:

Os Jesuítas não desconheciam certamente as indicações sobre o edifício teatral no De Architectura de Vitrúvio, obra que surgia no rol de leituras recomendadas para os colégios. ${ }^{52}$ Também não desconheceriam os contributos dados à exegese desse texto por humanistas de nomeada como Leo Battista Alberti, Daniel Barbaro, Sebastiano Serlio e Giacomo Vignola, este último o famoso arquitecto da Igreja del Gesù em Roma.

Da representação da tragédia Saul de Miguel Venegas, onze anos antes, temos o seguinte testemunho sobre o palco e o cenário:

49 Cf. Arist., Poet. 1450b, 1453b e 1462a.

50 "Quod euenisse et rerum uarietate, et scenae apparatu, et actorum uenustate concedam potius, quam aliqua carminis et dictionis bonitate. " - BNL, cod.3234, p. 6.

51 "Nam nuper habiti regis in conuiuio, / Tragico bibistis in epulo per biduum: / Hoc cena modica consequetur prandium." (Tragicae comicaeque actiones, cit., p. 226).

52 Num rol de autores necessários ao estudo da eloquência, elaborado pelo jesuíta Pedro Perpinhão para o colégio romano, em 1565, inclui-se também Vitrúvio. Cf. MP II, p. 641. 
"Hizose un cadahalso de madera, muy grande, en medio del patio a donde se representó. A una parte del estavan hechos unos repartimientos a manera de casas de donde salian las figuras en diversos actos"53.

Para a Sedecias, representada igualmente no pátio do colégio onze anos mais tarde, ter-se-á seguido certamente procedimento idêntico no que respeita ao cadafalso, com excepção do cenário, que não podia deixar de ter em conta o enredo específico desta tragédia. Assim, a cidade representada no cenário foi Jerusalém, com seus palácios e casario, muralhas circundantes, munidas de torres e ameias, e as respectivas portas. Nesse conjunto, o templo ocupava posição de destaque. ${ }^{54}$ Para aceder às torres e ameias haveria escadas. Divisar-se-iam montes e bosques e ilusões de fumo subindo dos altares onde se sacrificava a Baal. É de crer que o palco construído teria mais que um nível, suficientemente espaçoso para acomodar grande número de personagens em cena, como sugere o enredo, e permitir a vários actores correr através dele, horrorizados ou em cólera, em vários pontos da peça. ${ }^{5}$

$\mathrm{Na}$ frente da cena constariam as três portas da convencionada cena trágica humanista, inspirada em Vitrúvio, a saber: a porta régia, ou central, a que parece aludir o texto quando fala na grande porta ("portam ingentem" - v. 401) por onde entra o rei com o seu séquito, e as hospitalia, uma de cada lado, por onde se movimentariam outras personagens, designadamente Jeremias e o Moço. Outros locais pressupostos no enredo encontrar-se-iam igualmente sugeridos no cenário, como o santuário donde falava a personagem Oráculo, dando voz à mensagem divina. Esse local apresentar-se-ia à plateia como uma representação da glória, recurso cenográfico muito usado na Idade Média e que consistia numa pequena câmara envolta em nuvens, destinada a assinalar aparições celestiais. Além deste, temos ainda a prisão de Jónatas e a cisterna para onde foi atirado Jeremias e donde viria a ser retirado por cordas. Para enquadrar unitariamente as várias construções do cenário, é de supor que funcionasse o efeito da ilusão criada pela perspectiva, cujas leis na pintura e na arquitectura foram zelosamente estudadas pelos humanistas.

- Efeitos sonoros e visuais:

Para os primeiros, não faltam sugestões na fábula dramática: assustadores trovões anunciando as solenes proclamações do Oráculo; nas cenas militares, sons de trombetas e clarins, gritaria entre soldados de campos opostos, com fanfarras militares,

53 MHSI, LQ vol. 6, p. 362

54 "...flammas in tecta et templum quod erat ad speciem extructum coniecissent" - ARSI, Lus. 59, fl. 33r (trad.: "...lançassem fogo às casas e ao templo, que estava construído bem à vista..."

55 Algumas notas didascálicas relativas ao cenário que acompanham o texto manuscrito duma peça homónima representada em Colónia (Hierosolyma euersa per Nabucodonosorem), para cujo enredo foram "transplantadas" várias cenas da Sedecias, parecem aludir a esse nível superior do palco ("e superiori loco"), donde falariam certas personagens como os "oppidani" e os mensageiros. Cf. Nigel Griffin, "A Portuguese Jesuit Play in Seventeenth-Century Cologne", Folio 12 (June 1980), p. 58. 
onde não faltaria ainda o rufar dos tambores (v. 2284). Estes sons intensificar-se-iam nas cenas finais, em especial no assalto à cidade, com o alvoroço e a algazarra dos militares (vv. 3399-3406), a par com o clamor aflitivo dos populares (v. 3449), por entre o crepitar das chamas (3389) e o fragor das armas.

No tocante aos efeitos visuais, serão de referir as luzes de cena, a maquinaria e o guarda-roupa. Haveria luzes, certamente, na dianteira do palco, dissimuladas por panos, para iluminar a cena em geral. ${ }^{56}$ É possível que o templo e os palácios surgissem iluminados, já que aparecem descritos com adjectivos como "auratus" ("templum auratum" - v. 3583; "tecta aurata" - v. 547), sugerindo um brilho que, além de dado pela pintura, poderia também ser realçado por luzes neles incidentes. Mas neste como noutros casos é bem possível que o texto sugira mais do que o que a cena oferecia. Quanto à maquinaria utilizada, poderá ter-se recorrido a um sistema de roldanas, ou algo equivalente, para içar duas personagens ex-machina: o Anjo do prólogo e o Oráculo. A sua saída de cena, vv. 183-4 e 2896, respectivamente, simula um voo para as alturas. Quanto ao guarda-roupa, e aqui incluímos, além da indumentária, toda a utensilagem utilizada, oferece-se-nos dizer que estamos, porventura, perante a componente do espectáculo que mais brilho lhe deu. Neste caso, testemunhos externos corroboram claramente as fortes sugestões advindas do texto da tragédia. O rei, com suas vestes magníficas, tem a distingui-lo o diadema e o ceptro reais (v. 1285); os nobres destacam-se pela brancura de suas vestes (vv. 554-5); trazem a cabeça ornada com uma mitra (v. 2524) ou uma tiara (v. 2742), tal como os sacerdotes; os chefes militares cingirão naturalmente uma espada.

Cenas há que impuseram à plateia uma impressiva carga visual. Uma delas terá sido a cena 6 do acto II, de incentivo à guerra, onde o rei judeu é revestido de suas armas; outra, com maior colorido e exotismo, é a do regresso de Nabucodonosor a Jerusalém, após ter derrotado o Faraó Necao, na cena 12 do acto IV. Os soldados israelitas sobem em alvoroço às muralhas, de armas na mão, para defender a cidade (v. 2978); passam sinais entre si, com a ajuda de espelhos (v. 3032); vêem as tropas assírias conduzindo uma multidão de prisioneiros e ostentando, espetadas na ponta das suas lanças, cabeças humanas mutiladas (vv. 2990-1); entre os prisioneiros figuram ilustres generais egípcios, que far-se-iam reconhecer, certamente, pelo exotismo da indumentária típica do seu país.

Mas o momento mais espectacular da encenação terá sido, sem dúvida, o da tomada de Jerusalém, com o incêndio que se seguiu, na cena 3 do acto V. Faz-se aí um simulacro de batalha no assalto final à cidade, com soldados a avançarem de todos os lados, os generais caldeus a irromperem com toda a sua infantaria, as muralhas a serem atacadas em muitos pontos e os mesmos soldados a correrem

56 Sobre a valorização da cena e no que concerne ao sistema de iluminação, ATTOLINI, Teatro e spettacolo nel Rinascimento, Roma - Bari, Laterza, 1988, p. 63, enumera resumidamente as sugestões deixadas por Serlio no seu tratado: luzes colocadas sobre o fundo do céu da cena; tochas situadas na zona dianteira do palco, disfarçadas por panos; luzes (de candeias?) filtradas através de bocas de água colorida por detrás das janelas e nos bastidores. 
para a cidade e a incendiarem as moradias e o templo. O cenário terá ardido completamente, com fogo alimentado pelo enxofre colocado no cenário. Luís da Cruz, na biografia que escreveu do coadjutor temporal Domingos João, que muito o ajudou nessa ocasião, evoca esta cena memorável, cuja concretização, diz ele, oferecia riscos que, felizmente, não se concretizaram em nenhum desastre. ${ }^{57}$

Sobre a enorme quantidade de adereços implicados numa cena destas, com inúmeros figurantes trajados a rigor e munidos de diversas armas, harmonizam-se bem os testemunhos quer do próprio Luís da Cruz, no já referido prefácio inédito ao seu teatro, quer o dum tal "frater" Damião Soares, jesuíta que escreveu uma carta para o Geral de Roma, fazendo uma espécie de balanço crítico desta memorável acção cénica. ${ }^{58} \mathrm{O}$ primeiro afirma ter-se reunido utensilagem vinda de muito lado, com destaque para as adagas e punhais fornecidos pelos arsenais do rei, 59 o segundo mostra-se inquieto com as obrigações contraídas em tantos empréstimos. ${ }^{60}$

\section{- O desempenho dos actores}

Já vimos como Luís da Cruz refere a elegância dos actores como uma das principais causas do fascínio exercido sobre o público. O relato que seguiu para Roma sublinhava o decoro observado na representação no que respeita ao domínio de voz e da expressão corporal, ${ }^{61}$ muitas vezes em cenas extremamente animadas por grande número de figurantes, com personagens de grande distinção, envergando indumentária requintada.

\section{- Os coros e a música}

Eis outra componente com importância decisiva na magnificência e no esplendor do espectáculo. Luís da Cruz refere-se com orgulho aos coros das suas peças, como propiciadores de um dos momentos altos do espectáculo:

57 “...et necesse esset ad expugnationem urbis pugnae esse simulacrum. Atque ideo milites hinc et inde erant proferendi, cum duces Chaldaei militariter irrupissent cum toto peditatu et muri multis partibus ab oppugnatoribus peterentur et cum hostes in urbem peruolassent, flammas in tecta, et templum quod erat ad speciem extructum coniecissent. Dante diuino numine hoc beneficium nostris, quod tanta res bene agi potuerit, sine periculo: praesertim cum multis locis in puluerem sulphureum ignes mitterentur." - ARSI, Lus. 59, fl. 33r. (Trad.: "...era necessário, para o assalto à cidade, haver um simulacro de batalha. E por essa razão deveria fazer-se avançar soldados de ambos ao lados, quando os militares Caldeus irrompessem militarmente com toda a infantaria, e as muralhas fossem abordadas em muitos pontos pelos assaltantes, e quando os inimigos se precipitassem em direcção à cidade e lançassem fogo às casas e ao templo, que se encontrava edificado bem à vista. Por graça de Deus é que foi possível aos nossos cumprir devidamente esta importante empresa sem correr riscos, principalmente quando em muitos pontos o fogo era pegado ao enxofre."

58 Ver no anexo 2 a esta "introdução" transcrição de excerto desta carta.

59 "...supellex undique comparata fuit. Et ex regis opulentissimis armariis gladii et pugiones..." - BNL, F.G. 3234, p. 11;

60 "E ainda que não fora por outra cousa, senão que se <honrem> tirar de obrigações que causam emprestemos neste tempo, seria proveitoso apartarmo-nos disso" - ARSI, Lus. 64., fl. 152r. Cf. "Anexo 2" desta "Introdução".

61 "Omnes enim ita partes suas egerunt, ita uoce et gestu, eius personae quam quisque gerebat decorum seruarunt." - ARSI, EPP. NN. 103, fl. 116r. 
"Há coros em todas estas peças, pois sem música o teatro não deleita. E além das flautas que nunca faltaram, sempre na nossa obra é de esperar o canto. Na verdade, por que motivo havia o coro de ser representado atrás do pano, para que se ouvisse mal? De fora do proscénio é conduzido em direcção à cena, o que tem um efeito admirável. Portanto, fizemos desfilar os que cantam com vestes aparatosas e neste género podem porventura os Portugueses ter feito algo de notável". ${ }^{62}$

A música seria a várias vozes, mas até hoje só se identificaram as partituras com o naipe dos sopranos. Quanto ao acompanhamento instrumental, tinha pelo menos o das flautas. O tom da música, segundo relato enviado para Roma, revelava-se adequado quer ao argumento quer à gravidade característica de cada acto. ${ }^{63}$

\section{6 - A intenção do dramaturgo}

A tragédia Sedecias, enquanto artefacto poético, tal como acabamos de a descrever, fala por si das intenções que motivaram o dramaturgo. Luís da Cruz elaborou um drama ao gosto da época, traduzindo ideias que, naqueles tempos pós-tridentinos, eram avançadas, em contexto católico, quanto aos fins da poesia. Mais que imitar o necessário e provável, na esteira de Aristóteles, a poesia deveria, na óptica de Lorenzo Gambara (1496-1586), poeta e jesuíta, ensinar e deleitar imitando a verdade, sendo esta a revelada por Cristo. ${ }^{64}$ António Possevino, igualmente jesuíta, propõe na sua Bibliotheca Selecta, a utilização instrumental da poesia pagã antiga, aproveitando dela tudo o que possa ser integrado na nova poesia, de carácter cristão, como provérbios ou discursos para instrução moral. ${ }^{65}$

Já vimos como Luís da Cruz soube aproveitar Séneca pondo-o ao serviço do didactismo moral que percorre a Sedecias. Esta ênfase dada à moralização traduzse num esforço de persuasão que recorre não apenas à sentença mas também, e sobretudo, a um conjunto de emoções no domínio do espectacular, segundo uma lógica de efeitos impressionantes. Estamos aqui bem longe da poética da Iephthes de Jorge Buchanan, pautada por uma sobriedade de processos cénicos e que, apesar disso, se revela eficaz na obtenção de um forte efeito catártico: reduzido número de personagens em cena e diálogos de grande força interior que espelham bem o drama psicológico e, por si só, comovem a plateia. Em Luís da Cruz, ao invés, temos o palco quase sempre animado de muitas personagens, em episódios variados,

62 Luís da Cruz, op. cit., vol. 2, p. 36-37.

63 "Modi quoque et cantus, quos fecerunt musici, sic ad argumentum accommodati erant, ita in singulis actibus cum ipsius Tragoediae grauitate consentiebant" (ARSI, Epp. NN. 103, fl. 116r.).

${ }^{64}$ Cf. Bernard Weinberg, History of literary criticism in the Italian Renaissance, Chicago, University of Chicago Press, 1961, p. 308-309.

65 Cf. Ibid., 337-8. A Bibliotheca Selecta é uma obra que faz uma monumental recensão a toda a literatura antiga, com o objectivo de evidenciar nela tudo quanto possa aproveitar a uma poética de cunho cristão. Cf. Ibid., pp. 337-8. 
conjugados com efeitos cénicos de vária ordem, a que já nos referimos. ${ }^{66}$ O modelo Séneca inseria-se perfeitamente nesta poética, na medida em que ajudava a tornar o tema cruel e terrível, o que redundaria "no aplauso dos espectadores e em estima granjeada pelo poeta". ${ }^{67}$

Luís da Cruz teve plena consciência, na altura de reformular o texto teatral em ordem à sua edição, de que agira contra as tendências poéticas que então se impunham crescentemente e que defendiam, entre outras coisas, uma unidade de acção com enredos concentrando acontecimentos ocorridos num período aproximado de vinte e quatro horas. Ele defende-se, porém, com uma exegese pessoal de Aristóteles, advogando uma unidade de acção em sentido amplo, ou seja, a que consegue dar expressão à peripécia dos acontecimentos. Contrapõe, além disso, a verdade da Bíblia como a base do enredo, uma verdade que não tolera processos de efabulação, mas apenas uma narração fiel. ${ }^{68} \mathrm{~A}$ esta unidade de acção chama Frèches unidade de interesse. ${ }^{69}$

Fiel à exegese católica, a Sedecias é, ao mesmo tempo, uma peça de tese e um drama histórico. A narração bíblica levada à cena foi servida por um discurso onde assomam, com forte recorrência, os principais pontos duma moralização pretendida, mais do que pelo autor, pelos superiores da Companhia, como já sugerimos. A personagem do rei judeu foi construída de modo a funcionar no enredo como o principal catalisador dessa moralização motivada, pensamos, por um conjunto de circunstâncias ligadas à presença do jovem rei português entre os espectadores. $\mathrm{O}$ que as crónicas do tempo transmitem sobre um rei adolescente sonhador, exaltado por ideais de grandeza e heroísmo, entusiasta dos exercícios militares e com ânsia de combater os Mouros, parece encontrar reflexos no discurso do enredo, designadamente na ênfase especial dada às questões da guerra e do exercício do poder. ${ }^{70}$ Somos assim levados a pensar que o dramaturgo conduziu o seu labor poético privilegiando para o efeito catártico determinados destinatários, a começar pelo rei adolescente, em cuja educação a Companhia já se encontrava comprometida na pessoa do jesuíta Luís Gonçalves da Câmara, seu confessor. A representação da

${ }^{66}$ Luís da Cruz segue o modelo de tragédia defendido em meados do século por Giambattista Giraldi Cinthio, na sua Lettera sulla tragedia (1543): coro móvel contra coro estável à maneira grega; muitas personagens em cena, de acordo com uma acção onde pontificam reis, cujo séquito é numeroso; divisão da acção em actos. Tudo isto emprestava esplendor à representação, dando bem estar à plateia e funcionando como um antídoto contra o enfado dos espectadores. Cf. Ibid., p. 912-918.

67 Era nestes termos que Bartolomeu Ricci (1490-1569) indicava Séneca como modelo para a tragédia. Cf. Ibid., p. 103.

68 Cf. pontos de vista de Luís da Cruz sobre esta e outras questões poéticas do seu teatro em Manuel Barbosa, "Luís da Cruz e a poética teatral dos Jesuítas", cit..

69 Cf. Frèches, op. cit., p. 500.

70 Sobre a vida de D. Sebastião, continua sendo leitura de muita utilidade, apesar de muitos estudos posteriores, o trabalho de J. M. Queiroz Veloso, D. Sebastião, 1554-1578, Lisboa, 1945. Sobre a questão da guerra no enredo da Sedecias cf. Manuel Barbosa, "Ecos de contemporaneidade na tragédia Sedecias: a questão da guerra" in Luís da Cruz, S. J., e o teatro jesuítico nos seus primórdios, cit., pp. 89-101. 
tragédia era uma oportunidade para, por um lado, inculcar no jovem rei um modelo de governante e, por outro, para o fazer reflectir sobre o uso do poder. O destino trágico do rei judeu, posto em cena com requintes de horror, far-lhe-ia sentir ao vivo as consequências terríveis que advêm dum mau governo.

Quaisquer que tenham sido os verdadeiros intuitos de Luís da Cruz ao compor a tragédia, mais ou menos influenciado pelo contexto sócio-político da altura, o certo é que muito do discurso do enredo permite uma leitura alusiva à contemporaneidade, designadamente à questão de Alcácer-Quibir que, neste caso concreto, poderá ter sido conscientemente sugerida pelo próprio Luís da Cruz quando reformulou tardiamente o texto, com acrescentos como o destes versos do coro I:

"Hinc multa auspiciis cepta fauentibus / quae spes uana tulit, mox lacrymabilis / Turpi ludibrio sustulir exitus" - vv. 809-811

[Trad.: "Daí que muitas coisas iniciadas sob os melhores auspícios, movidas por falsas espectativas, em breve terminem tristemente, mercê de infame ludíbrio.”]

Esta leitura profética da tragédia à luz da batalha que ditou a perda da pátria existiu realmente, como o prova o seguinte excerto, em tradução, da Synopsis de António Franco: Ultrapassou as expectativas a tragédia sobre Sedecias, representada em dois dias, da autoria do P. Luís da Cruz. Quem diria então que para o exultante Sebastião a lamentável desgraça de Sedecias equivalia a um funesto vaticínio sobre a sua própria ruína. ${ }^{71}$

\section{O texto da Sedecias}

\section{1 - Colação dos testemunhos e fixação textual}

O texto da tragédia Sedecias chegou até nós com uma variedade razoável de testemunhos manuscritos, indicadores do grande interesse que terá despertado logo após a sua representação em Outubro de 1570. O texto aprontado pelo autor começou desde logo por ser objecto de várias cópias, para os ensaios, tarefa em que se terá envolvido bastante gente. ${ }^{72}$ Mas terá sido após a representação, devido à fama que dela correu (tão patente, como já vimos, na correspondência jesuítica), que surgiu o interesse pelo texto da tragédia, sujeito a partir de então a múltiplas cópias, movidas por objectivos vários. A tipologia de cada códice remete para tais objectivos.

No seu conjunto, os testemunhos manuscritos remetem para duas fases da tradição do texto, claramente distintas: a primitiva e a definitiva. A primitiva é a que surge

71 Cf. A. Franco, Synopsis Annalium Societatis Iesu in Lusitania ab anno 1540 usque ad annum 1725, Augustae Vindelicorum et Gaecii, 1726, p. 91.

72 "Deixemos o tresladar de tantos milhares de versos que tinha a tragédia em que tantos irmãos se ocuparam” (ARSI, Lus. 64, fl. 152v). 
ligada à representação e abrangerá um amplo período de aproximadamente trinta anos. É presumível que, durante esse tempo, o texto circulasse entre os colégios da Companhia, copiado várias vezes. ${ }^{73} \mathrm{~A}$ fase definitiva relaciona-se com a preparação da edição princeps, ocorrida em Lyon, em 1605, na tipografia de Horácio Cardon. Terá sido em finais do século que Luís da Cruz recebeu a incumbência superior de preparar os seus textos teatrais, tendo em vista a sua edição, como se depreende da afirmação inicial do prefácio às Tragicae comicaeque actiones:

"Tinham podido estas peças, que estiveram, algumas delas, escondidas mais de trinta anos, continuarem ainda hoje nas trevas do esquecimento..." ${ }^{74}$

Apresentemos então sumariamente os vários códices que contêm o texto manuscrito da tragédia Sedecias, já com as siglas que os identificarão no aparato crítico:

C: Coimbra, BGUC, cod. 993: "Rerum scholasticarum quae a patribus ac fratribus huius Conimbricensis Collegii scripta sunt. Tomus secundus"

Formato in folio. Numeração primitiva de 1 a 478 fólios. Papel do mesmo tipo, o chamado papel pellegrino, como se deprende da marca de água. Encadernação primitiva em madeira revestida a couro castanho escuro. Heterogeneidade de paginação e de conteúdo, registado por diversas mãos. Múltiplas intervenções, também de diversas mãos, com comentários nas margens, inutilizações a risco, correcções e inserções, tanto marginais como interlineares. Letra humanista da segunda metade do séc. XVI, com excepção dos fólios finais, onde se dá o catálogo dos lentes de Filosofia e Teologia dos Colégios de Coimbra e Évora, em letra presumivelmente da segunda metade do séc. XVII. O texto da tragédia Sedecias ocupa os fólios 55r-102v.

Pelas suas dimensões e pelo material nele incluso, repartido entre peças de oratória e de poética, conclui-se que a feitura do presente códice obedeceu ao propósito de registar os textos alusivos aos momentos mais festivos da vida do colégio. É o segundo tomo duma série de códices de funcionalidade idêntica, de que se conhecem também o tomo I (Lisboa, BN, cod. 3308), o tomo V (Coimbra, BGUC, cod. 994) e o tomo VI (Lisboa, ANTT, cod. 1963). ${ }^{75}$

\section{K: Coimbra, BGUC, cod. 1235 [Dramas bíblicos]}

3+279+3 fólios em papel, 130x85mm, numerados tardiamente em árabe. Papel de diversa origem. Encadernação primitiva em cartão revestido a couro gravado, de

\footnotetext{
73 Poderá eventualmente ter sido objecto de outras cópias fora deste contexto.

${ }^{74}$ P. Luís da Cruz, S. J., O Pródigo..., cit., p. 23. Note-se que a primeira peça do autor, a tragicomédia Prodigus, foi representada em 1568.

75 Este último tomo só recentemente foi identificado. Cf. Sebastião Tavares de Pinho, "Um códice latino da literatura jesú́tica quase desconhecido: o cod. 1963 da Livraria dos manuscritos dos ANTT", Humanitas 57 (2005) 351-382.
} 
cor negra. Paginação regular. Títulos correntes com indicação do título do drama, na página da esquerda, e do respectivo acto, na da direita. Letra humanista, de uma só mão, distribuída com grande regularidade por cada página, sem grandes intervenções para correcções, rasuras ou acrescentos.

Pelo formato mais reduzido e pela identidade de conteúdo (teatro de tema bíblico, com três dramas de Luís da Cruz e um de Miguel Venegas), somos levados a pensar que foi concebido para uso pessoal, e o nome do seu eventual possuidor pode bem ser o que surge indicado no primeiro fólio de guarda: "F. Constantino Pinto".

\section{T: Lisboa, ANTT, Manuscrito da Livraria 2031.}

Título no frontispício: "Tragoedia de excidio urbis Hierosolymae capto rege Sedecia per Nabucodonosorem Assyriorum regem"

[2]+[80]+[2] fólios em papel, de 210x145mm. Encadernado em pergaminho. Sem foliação. Texto disposto com grande regularidade, em páginas devidamente normalizadas e invariavelmente ligadas com reclamos. Identidade de mão, inclusive nas poucas correcções, e de instrumento de escrita. Marcas de uso: no fl. [3r], canto superior direito, pode ler-se "S. Antão". A mesma indicação surge no fl. [80r], igualmente no canto superior direito.

Por esta descrição e pelo facto de o conteúdo do códice se resumir ao texto da tragédia Sedecias, pensamos estar aqui perante uma encomenda do Colégio de Santo Antão, de Lisboa. Por outro lado, atendendo ao desenho da letra, extremamente parecida com a de cartas autógrafas de Luís da Cruz, e à extrema correcção desta versão do texto, pensamos que esta manus docta, que se autocorrige algumas vezes, é a do próprio autor da tragédia. ${ }^{76}$

\section{M: Coimbra, BGUC, M.M. 70 [Livro de música para sopranos]}

1+9+1 fólios de papel, de 132x198mm. Várias marcas de água. Capas modernas de cartão revestido de tecido de cor acastanhada. O conteúdo resume-se a peças de música religiosa e profana, em partituras destinadas apenas aos naipes de vozes brancas. A música religiosa tem a ver com o cerimonial do Mosteiro de Santa Cruz de Coimbra. ${ }^{77} \mathrm{Na}$ música apresentada como profana incluem-se as de coros de alguns dramas escolares jesuíticos, encontrando-se a letra e a música dos cinco coros de Sedecias nos fólios 91v-95v., da autoria de Frei Francisco de Santa Maria que é, de resto, igualmente autor da maioria dos trechos musicais deste códice. ${ }^{78}$

\footnotetext{
76 Sobre a identidade da letra atribuível a Luís da Cruz, cf. Manuel Barbosa, Bíblia e tradição clássica...cit., pp. 287-290 e 337-340.

77 Cf. Owen Rees, Polyphony in Portugal c. 1530 - c. 1620. Sources from the Monastery of Santa Cruz, Coimbra, Garland Publishing, Inc., New York \& London, 1995, pp. 297-305, onde se pode ver uma metódica descrição de conteúdo tão específico como o do presente códice.

${ }^{78}$ Em Ernesto Gonçalves de Pinho, Santa Cruz de Coimbra centro de actividade musical nos séculos XVI e XVII, Lisboa, F. Calouste Gulbenkian, 1981, p. 172, surge citado um passo
} 
$\boldsymbol{E}$ : Évora, BPE, cod. CXIV/1-9: [Teatro de Luís da Cruz]

332 páginas em papel, de 210x155mm. Paginação com irregularidades. Encadernação primitiva em carneira. Títulos correntes em cada página, indicativos da peça e do respectivo acto. Texto a uma só coluna, de espaço bem delimitado, com distribuição muito regular. Escrita homogénea, de uma só mão. Poucas correcções ou rasuras. No plano posterior da capa surge escrito "Collegio de Coimbra".

Este códice distingue-se dos anteriores essencialmente pelo facto de a versão do texto dos dramas de Luís da Cruz aqui testemunhada (ou seja, a tragédia Sedecias e a tragicomedia Iosephus) coincidir praticamente com a versão impressa de Lyon. Este códice, por outro lado, irmana-se, na sua materialidade e no modus scribendi, com outro existente na Biblioteca Nacional de Lisboa, que contém a comédia Vita Humana e a tragicomédia Prodigus, em versões de texto igualmente da fase definitiva. ${ }^{79} \mathrm{O}$ mesmo tipo de letra de ambos os códices faz-nos pensar, como há pouco, na mão de Luís da Cruz. ${ }^{80}$ Parece poder concluir-se, sem grandes riscos de errar, que estamos aqui perante o texto final da tragédia, revisto pelo próprio autor, em ordem à sua edição.

A colação dos textos manuscritos conduz-nos de imediato à conclusão, já explicitada, de nos encontrarmos perante duas fases do texto da tragédia, sendo a definitiva representada pelo texto do códice eborense. Nos vários testemunhos da fase primitiva, parece razoável afirmar que o texto de $T$ remeterá para um momento posterior dessa fase primitiva, com intervenção do próprio autor. Este, trabalhando sobre o texto primitivo, muito antes de pensar ainda na sua edição, teria já excluído porções de texto que surgem igualmente excluídas no texto da versão final. Refirome aos blocos de versos após o v. 34, no prólogo, os v. 272 e 284, no acto I.

O texto que baseia a tradução pretende ser o que melhor exprimirá a última vontade do autor, falecido pouco antes de ver impresso o seu teatro na edição saída da tipografia de Horácio Cardon, em Lyon $(L)$. Entre o texto do manuscrito de Évora e o de Lyon a concordância é muito grande, ou melhor, quase unânime. O desacordo do texto impresso em relação ao manuscrito de Évora assenta o mais das vezes em gralhas tipográficas, algumas evidentes ("sclesti" por "scelesti" - v. 262), outras vezes em eventuais erros de distracção ("ridebunt" por "redibunt" - v. 977) e, finalmente, em variantes estilísticas, muito diminutas ("Hortor" face a "Admoneo" - v. 1054). Preservámos estas últimas, como expressão da vontade do autor já em

do Rol dos Cónegos Regrantes de Santo Agostinho (...) onde se pode ler, nomeadamente: “... compôs muitos choros pêra tragédias, especialmente pêra hua grande que el Rei dom Sebastião veo ver a esta cidade,...". Sobre a música dos coros de Sedecias, cf. Owen Rees, Polyphony in Portugal cit..

79 Trata-se do códice: BNL, cod. 3234.

80 Vide nota 70 . 
último momento. Em todo o caso, nesta delicada tarefa de fixar a versão definitiva do texto, ponderámos uma a uma as variantes entre o texto manuscrito de Évora (E) e o texto impresso de Lyon $(L)$, com o propósito de só contrariar este quando a lição de $E$ se apresentasse com grande consistência, passando pelos testes da métrica e da tradução. Para este discernimento contribuiu também o texto dos testemunhos da fase primitiva. O isolamento de $L$ face à unanimidade dos restantes testemunhos pesou bastante na rejeição da sua lição, da mesma forma que a sua concordância com $T$ conduziu, em princípio, ao respeito da sua lição, em detrimento da partilhada pelos restantes testemunhos. Os seguintes casos, em que a lição adoptada surge à esquerda, ilustram o que acabamos de dizer:

$\begin{array}{ll}\text { v. } 433 \text { audiri } L T & \text { audire } K C E \\ \text { v. } 1852 \text { cadit } K C T E & \text { cedit } L \\ \text { v. } 2001 \text { facti } K C T E & \text { fasti } L \\ \text { v. } 2266 \text { Colligite KCTE } & \text { Collige } L^{81}\end{array}$

Tendo em conta que $E$ e $L$ nos oferecem um texto praticamente coincidente, e que, se, por um lado, as gralhas e as distracções de $L$ surgem corrigidas em $E$ e, por outro, este faz concessões àquele em algumas variantes estilísticas, resulta que o texto aqui fixado apresenta um grau de coincidência praticamente idêntico em relação aos dois testemunhos. Porque se trata da primeira edição crítica do texto da tragédia, optámos por seguir o manuscrito de Évora, ao qual concedemos o estatuto de codex optimus, pelo carácter de autógrafo que aparenta ter. Daí o termos indicado à direita do texto, entre parêntesis rectos, a paginação de $E$.

Embora achássemos que respeitar a pontuação original do texto em $E$ representaria preservar o código de leitura concebido pelo poeta para o seu próprio texto, optámos por aplicar ao texto nova pontuação, de acordo com a nossa leitura pessoal, espelhada na tradução. A razão principal foi a de que ainda não são claros os critérios que norteavam os humanistas num domínio onde não demonstram unanimidade de critérios no uso de cada um dos sinais de pontuação.

\section{2 - Critérios de edição}

No domínio da ortografia interviemos no sentido de normalizar práticas díspares nos diversos testemunhos, sendo de salientar:

- correcções de formas divergentes e erradas de auctor e suas cognatas, como autor e authoritas, bem como da confusão de conditio com condicio, de étimos e significados diferentes;

- normalização, em matéria de vocalismo, dos ditongos ae e oe e da vogal longa $e$, preferindo caecus, caelum, maestus, etc., e respectivos derivados, a coecus, coelum, moestus, etc. ou ceterus, fecundus, femina, etc., a caeterus, foecundus, foemina, etc.; do uso errado de $y$ em vez de $i$, em hybernus, inclytus, lachryma (ou lacryma),

81 O segundo e o quarto caso resolvem-se com o recurso ao teste da métrica. 
ocyus, sydereus, sylua, por bibernus, inclitus, lacrima, ocius, sidereus, silua; ao invés, coryphaeus em vez de coriphaeus;

- normalização do melhor uso da aspirada $h$ em palavras como carus, catena, feretrum, incohatus, istaecne, letum, sepulcrum, tiara, tus e umerus, e suas cognatas, em vez de charus, cathena, pheretrum, inchoatus, isthaecne, lethum, sepulchrum, thiara, thus e humerus;

- em matéria de assimilação de consoantes, uniformização pelas grafias consideradas preferíveis, optando, por exemplo, por umquam, utrimque, quamuis, quicumque, etc., em detrimento de unquam, utrinque, quanuis e quicunque;

- opção pelo uso da oclusiva epentética, preterindo formas como demsi, demtam, peremtam e outras similares em favor de dempsi, demptam, peremptam, etc;

- normalização do uso de geminadas, preferindo litus, litoris, religio, etc., a littus, littoris, relligio e, ao invés, bracchium a brachium;

- correcção do dígrafo -ci- seguido de vogal por -ti-, em palavras como nuncius ou concio, que passaram a nuntius e a contio.

$\mathrm{Na}$ utilização das iniciais maiúsculas adoptámos uma solução de compromisso, seguindo umas vezes $E$, outras vezes $L$. As iniciais dos versos são sempre maiúsculas, como sucede já no texto manuscrito. Seguimos mais $L$ na colocação de maiúscula após ponto final (.), de interrogação (?) e de exclamação (!). O mesmo se fez, com as várias designações de Deus ("Rector", Regnator", "Vindex", etc.), transformando em regra a prática tendencial mais preponderante em $L$. A palavra "rex" surge como nome próprio quando designa Deus ou se refere especialmente ao rei Sedecias, procedimento sistemático adoptado por $L$. O mesmo fizemos com o substantivo "tyrannus", em maiúscula quando se referia a Nabucodonosor ou a Sedecias. "Numen" é utilizado como nome próprio quando se refere à própria divindade e como nome comum quando designa um atributo desta, prática mais seguida por $E$.

As personagens surgem indicadas no início dos versos, a maiúsculas, em negrito, de forma abreviada e unívoca, em ordem a evitar confusões, existentes quer nos manuscritos quer no texto de Lyon, em relação a personagens como Gedelias e Godolias, por um lado, e Nabucodonosor e Nabuzardano, por outro. Nas didascálias de cada cena foram desenvolvidas as formas abreviadas.

Por outro lado, para melhor identificar a estrutura da obra, optámos por assinalar e numerar as cenas em que se divide cada acto, embora elas não venham designadas no texto latino.

O aparato crítico de variantes textuais ${ }^{82}$ que acompanha o texto latino desta edição ocupa, por economia de espaço, não apenas o rodapé da página do latim, à esquerda, mas também o da tradução portuguesa à direita, em que aquele se

82 As intervenções do editor no aparato, mediante abreviaturas e sinais diacríticos, cuja explicação antecede imediatamente o texto editado e a respectiva tradução, basearam-se em J. Bidez e A. B. Drachmann, Emploi dês signes critiques. Disposition de l'apparat dans les éditions savantes de textes grecs et latins. Conseils et recommandations. Bruxelles, Secrétariat de l'Union Académique Internationale - Paris, Les Belles Lettres, 1938. 
prolonga quando necessário. É um aparato de tipo negativo, isto é, a lição do texto é partilhada por aqueles testemunhos cujas siglas não surgem junto das respectivas variantes.

Este aparato crítico permitirá aos filólogos formarem um juízo sobre a maior ou menor justeza das nossas opções. Além disso, este aparato tem a virtude de apresentar a história dum texto nas suas diversas fases até à versão final impressa. Abriu-se assim uma perspectiva nova, em relação à edição de Lyon, resultante do facto de se ter recuperado o processo de elaboração do texto através dos testemunhos que subsistem, como convinha a uma obra em cuja tradição ganham grande realce as variantes de autor.

\section{A tradução}

No tocante à tradução, refira-se desde já que esta não é a primeira tradução da tragédia para uma língua vernácula. A Sedecias encontra-se traduzida pelo menos para alemão, em trabalho recente de Matthias Büttner, no âmbito duma dissertação que o habilitou a professor da Faculdade de Línguas e Literaturas de Otto-Friedrich, da Universidade de Bamberg. A editora Peter Lang publicou esse trabalho, em edição que apresenta a tradução acompanhada do texto latino e antecedida duma introdução bem sustentada por abundante bibliografia. ${ }^{83} \mathrm{O}$ texto latino aí transcrito é o de Lyon, expurgado quer de gralhas tipográficas, facilmente detectáveis, quer de outras leituras erróneas que o esforço de tradução acabou por sugerir a Matthias Büttner, como ridebunt em vez de redibunt (v. 977), por exemplo. Este meritório esforço de aprimoramento do texto de Lyon, porém, ficou, à partida, limitado, pois o autor não contou com a preciosa ajuda que lhe adviria da colação do texto impresso com os testemunhos manuscritos. ${ }^{84}$ Outro aspecto a realçar no trabalho de Büttner situa-se no domínio da imitação e da intertextualidade, com a detecção de inúmeros passos de obras de autores latinos evocados nos versos da Sedecias e indicados em rodapé. Trata-se dum esforço meritório, sem dúvida. Gostaríamos, porém, de ver nesse estudo de intertextualidade um especial relevo devido a Séneca, já que se trata do modelo mais actuante nesta tragédia. Veja-se, só para exemplo, o v. 1824 (R. "Audite ciues. Omnis in ferro est salus"), verso que retoma quase na íntegra, Sen. Herc. Fur, 342 ("sceptra obtinentur; omnis in ferro est salus"), ou o v. 3803 ("R. Quid liberi meruere? NABVC. Quod uiuunt Tui.") que quase decalca Sen. Thyest. 1100 ("TH. Quid liberi meruere? AT. Quod fuerant Tui"). Em ambos os

${ }^{83}$ Ludouicus Crucius, Sedecias: Die lateinische Tragödie von Luís da Cruz S. J.. Eingeleitet, herausgegeben un übersetzt vom Matthias Büttner. Peter Lang, Frankfurt am Main, 2004. (Clássica et Neolatina Studien zur lateinischen Literatur, 3).

${ }^{84}$ Por exemplo: no coro III, Büttner deixou inalterada a lição "mentibus", a meu ver errónea, já que todos os testemunhos manuscritos apresentam "montibus", de acordo, aliás, com o exigido pelo contexto ("rochas que resvalam dos montes..."). 
casos, Matthias Büttner não dá testemunho em rodapé desta intertextualidade tão notória que envolve Séneca na Sedecias.

Na tradução por nós efectuada tentámos, dentro do possível, manter uma correspondência verso a verso. Tratando-se dum texto humanista, procurámos preservar na tradução certas expressões e qualificativos que contribuem para o caracterizar como tal. Mantivemos, por isso, certos termos de cunho pagão a que os humanistas recorriam, sem pejo, para ilustrar conceitos cristãos. Assim, por exemplo, o epíteto "tonante", nos textos clássicos atribuído a Júpiter, mantivemo-lo na tradução, ao serviço da caracterização do Deus do Velho Testamento. Pelo mesmo motivo, traduzimos "Auernus" por "Averno" e não por "Inferno".

À tradução do texto principal, o da fase definitiva, resolvemos acrescentar a tradução de versos inteiros do texto primitivo suprimidos pelo autor aquando da reformulação do texto. A sua versão em português aparece incluída no aparato crítico do rodapé, dentro de parêntesis rectos, logo a seguir ao respectivo texto latino. Em três casos, em que o número de versos suprimidos constituía um bloco com alguma dimensão, tais versos e respectiva tradução, por uma questão prática, surgem em apêndices, colocados no final desta edição.

Embora o texto da Sedecias não se apresente com grande carga de erudição, antes pelo contrário, constituímos algumas notas ao texto traduzido, pensando sobretudo no eventual esclarecimento do leitor de cultura média. Tais notas contemplam essencialmente questões de ordem bíblica (personagens, acontecimentos e lugares), de ordem mitológica (esclarecimento de mitónimos e da funcionalidade do seu uso) e de ordem literária (problemas de imitação, de estilo, etc.). 


\title{
ANEXOS À INTRODUÇ̃̃o
}

\begin{abstract}
Anexo 1
ARSI, Lus. 59, fls. 5-98 [Ludovici Crucii] De uita et moribus Dominici Ioannis libri tres. [Excerto]

(fl. 32r) "...Eodem anno iam peste deuolante, mense octobri Conimbricam uenit rex Sebastianus cum patruo Henrico et principe Emanuelis regis nepote Eduardo. Secuta regem ut par erat bona pars nobilitatis lusitanae. Huc paulo post Dinastae et alii, ut regem salutarent, se contulerunt. Bartholomaeus a Martyribus longe clarissimus antistes Bracarae Conimbricam etiam accessit. Ille ipse est Pontifex eius urbis quem uniuersa Lusitania etsi uiuentem suspiciebat, nunc magis colit mortuum quam uiuum. Et studia in eum declarabat, propter mirabilem uitae sanctitatem. A quo uiuo certum est miranda perpetrata ob quae iam quintus haberi posset bracarensis sedis antistes, numeratus inter illos quattuor, iam olim in numerum coelitum relatos Petrum Ratensem dico, Martinum, Gerardum, Fructuosum. Cardinalis Henricus domi in Collegio propter eximium amorem, quo est societatem complexus, manere uoluit. Nec recusauit tenue hospitium suorum, uno cubiculo fere contentus. Et ipse Bartholomaeus cum hospitem Ioannem Soarium haberet, antistitem Conimbricensem, uirum inter caeteras / (32v) laudes admodum liberalem, nobiscum etiam habitare uoluit. At rex Sebastianus regiam sibi delegit, aula amplissima tectisque capacissimam, ubi superiores scholas rex auus Ioannes Academiae esse uoluit. His diebus octobri mense iam adulto, ad regem adolescentem excipiendum Tragoedia Sedecias de excidio Hierosolymae expugnatae et incensae a Nabuchodonosore tyranno Babylonio adornata erat exhibenda. Non facile dicerim quantum trepidationis apud nos esset. Rex frequens in Collegium eques ueniebat. Patebant fores principibus et nobilitati. Cardinali mensa ornabatur. Aliis in aedibus parabant nostri antistiti Bartholomaeo. Eluxit dies tragoediae dandae. Nocte ante accersiti quaesitique actores. Erant omnia occupata tragico apparatu et hospitibus amplissimis. Et si nihil esset aliud, id satis erat ut res maxime negotiosa redderetur. Hic Dominicus Ioannes suo illo in regno tranquillissimus, nihil perturbationis sentiebat, cum diligentia et inuicta ui uirtutis,
\end{abstract}


facile eum omnem tumultum superaret. At ipse unus omnia tantis hospitibus praeparabat. Et sine Deo bene iuuante talem extitisse per eos dies nemo credat. Nam etsi multum auctoritatis collegio accessit, quod rex tantus ad nos ueniret, quod patruum filium Emanuelis antistitem et Cardinalem, quod Eduardum principem, quod tot secum regulos et nobilitatem regni attulisset, quod biduum tragoediae bipartitae attentissimus spectasset, quod sedendo aut stando beneuole rebus adfuisset, tamen ipsi patres quorum ea res intererat aestuabant. Nec mirandum cum uiderent quietissimam nostrorum sedem, ab omni remotam trepidatione, ea frequentia aulica occupatam / (33r) tumultuari. Caeterum in Dominico Ioanne animaduersum nihil in tragica aulicaque procella quatefactum, egregie illorum dierum tempestatem sustinuisse et illo biduo quo dabatur Sedecias, non solum actoribus coenam parauisse, sed plurimis aliis quorum opera fuit utendum. Maxime cum illud opus sine multis in lucem edi non posset, et necesse esset ad expugnationem urbis pugnae esse simulacrum. Atque ideo milites hinc et inde erant proferendi, cum duces Chaldaei militariter irrupissent cum toto peditatu et muri multis partibus ab oppugnatoribus peterentur et cum hostes in urbem peruolassent, flammas in tecta, et templum quod erat ad speciem extructum coniecissent. Dante diuino numine hoc beneficium nostris, quod tanta res bene agi potuerit sine periculo: praesertim cum multis locis in puluerem sulphureum ignes mitterentur. At haec etsi multum turbulentiae habuere, fuere tamen felici euentu laeta, et spes laetitiae et existimationis antecedentem acerbitatem deuorabat, et dificultates perrumpebat. Secutae deinde publicae calamitates et ea temporis grauis commutatio, quae neminem Lusitanum non afflixit prima ipsa malorum congressione. Nam octauo anno ab eo quo Sebastianum uidimus uiuida florentem adolescentia, paterni et materni aui uirtutes referentem, suscepta ab eodem fuit luctuosa in Africam expeditio, quam dum res erunt Lusitania deplorabit. Amissum in ea pugna infelici, regem lamentabimur animi fortitudinisque ingentis, et captam nobilitatem regni aut occisam, nulla sane dignam uituperatione quam saepe ferunt male pugnatae pugnae. (...)

\section{[TRADUÇÃO:}

A vida e o carácter do Irmão Domingos João

$$
\text { (...) }
$$

Nesse mesmo ano, com a peste já em regressão, veio a Coimbra no mês de Outubro o rei D. Sebastião, acompanhado de seu tio, o Cardeal D. Henrique, e do Príncipe D. Duarte, neto do rei D. Manuel. Seguiu o rei, como convinha, boa parte da nobreza lusitana. Dirigiram-se também para aqui, pouco depois, outros dignitários, para saudarem o rei. Bartolomeu dos Mártires, de longe o mais ilustre dos prelados de Braga, chegou também a Coimbra. É este o famoso arcebispo desta cidade para quem toda a Lusitânia olhava com admiração, ainda em vida, e mais venera agora, depois de morto. E significava-lhe a sua devoção por causa da sua 
admirável santidade de vida. É dado como certo serem admiráveis as acções que empreendeu em vida, pelas quais poderia ser já considerado o quinto prelado da Sé bracarense, contado entre aqueles quatro já outrora incluídos no número dos bemaventurados, a saber, Pedro de Rates, Martinho, Gerardo e Frutuoso. O Cardeal D. Henrique, por causa da especial afeição que o liga à Companhia, quis ficar no Colégio. Nem recusou o modesto alojamento dos seus, tendo-se contentado apenas com um quarto. E o próprio Bartolomeu, embora fosse hóspede de João Soares, prelado conimbricense, varão, entre outros méritos, perfeitamente nobre, quis também ficar connosco. Quanto ao rei D. Sebastião, escolheu para si o maior palácio, com uma sala enorme e mansões, onde o rei D. João, seu avô, quis que fossem as anteriores escolas da Academia. Por esses dias, com o mês de Outubro já adiantado, devia ser representada a tragédia Sedecias, sobre a destruição de Jerusalém, tomada de assalto e incendiada por Nabucodonosor, tirano da Babilónia, preparada para acolher o rei adolescente. Não será fácil dizer todo o alvoroço que havia em nossa casa. O rei vinha frequentemente ao colégio, a cavalo. As portas encontravam-se abertas aos príncipes e à nobreza. Enfeitava-se a mesa para o Cardeal. Nas outras moradias, os nossos estavam às ordens do arcebispo Bartolomeu. Raiou o dia da representação da tragédia. Na noite anterior, os actores foram convocados e instruídos. Tudo estava ocupado com o aparato trágico e os consideradíssimos hóspedes. E se nada mais houvesse, isto era quanto bastava para tornar a tarefa muitíssimo absorvente. Aqui, Domingos João, muito tranquilo naquele seu reino, não sentia qualquer perturbação, vencendo facilmente todo aquele tumulto com o zelo e a força indómita da sua virtude. Mas ele próprio, sozinho, de tudo dava conta para hóspedes tão importantes. E ninguém acreditará que foi sem a boa ajuda de Deus que ele se manifestou como tal naqueles dias. Na verdade, embora tenha trazido muito prestígio ao colégio vir até nós rei tão importante, ter trazido consigo seu tio-avô, filho de D. Manuel, Bispo e Cardeal, o príncipe D. Duarte, tantos principezinhos e a nobreza do reino, o ter assistido com toda a atenção ao espectáculo da tragédia repartido por dois dias, o ter presenciado com benevolência a representação, sentado ou de pé, contudo, até os próprios padres, a quem este acontecimento interessava, estavam agitados. Nem é para admirar, ao verem a morada tão sossegada dos nossos, ao abrigo de qualquer agitação, em alvoroço, ocupada por aquele ajuntamento áulico. De resto, em Domingos João notou-se que, nada abalado no meio da tempestade trágica e áulica, suportou notavelmente a situação daqueles dias e, nos outros dois em que se representava a tragédia, não só preparou a ceia para os actores, mas também para muitíssimos mais, a cuja ajuda se teve de recorrer, sobretudo porque aquele empreendimento não se podia pôr de pé sem muita gente e era necessário, para o assalto à cidade, haver um simulacro de batalha. E por essa razão deveria fazerse avançar soldados de ambos ao lados, quando os militares Caldeus irrompessem militarmente com toda a infantaria, e as muralhas fossem abordadas em muitos pontos pelos assaltantes, e quando os inimigos se precipitassem em direcção à cidade e lançassem fogo às casas e ao templo, que se encontrava edificado bem à vista. Por 
graça de Deus é que foi possível aos nossos cumprir devidamente esta importante empresa sem correr riscos, principalmente quando em muitos pontos o fogo se pegava ao enxofre. Mas embora estas coisas tenham tido muita turbulência, apesar disso resultaram bem e a esperança da alegria e da apreciação anulava o incómodo inicial e vencia as dificuldades. Seguiram-se depois as calamidades públicas e aquela penosa mudança da conjuntura política que não deixou de afligir nenhum português com a primeira reunião de desgraças. Na verdade, oito anos após aquele em que vimos D. Sebastião florescendo numa adolescência vigorosa, exibindo as virtudes dos avós paterno e materno, foi empreendido pelo mesmo a funesta expedição a África, que a Lusitânia sempre lastimará. Lamentaremos o rei perdido nessa infeliz batalha que não é digna, certamente, de qualquer censura que frequentemente se faz às batalhas mal travadas.]

\section{Anexo 2}

ARSI, Lus. 64, fl. 152r-v: [Excerto de carta de Damião Soares, S. I., escrita em Coimbra e enviada para Roma em 8.1.1571

$(\ldots)$

A $3^{\text {a }}$ que podia V[ossa] P[aternidade] cortar pelas representações de Coimbra e dos mais colégios quanto fosse possível, e a perda que por aqui nos viesse vá sobre mim. E que os irmãos se dêem in primis à virtude, e secundariamente à filosofia e teologia, pois estas são as cousas em que se há de fundar a religião. Os demais brincos de representações se haviam de tirar quanto fosse possível, pois de todo não pode ser. Digo isto porque vejo que com semelhantes ocupações perdem os irmãos muito de seu principal estudo. E pondo exemplo nesta tragédia que agora se fez a el-rei, e noutras semelhantes, saiba V. P. que nos dão a mor perturbação aos irmãos, que quase não há em casa quem não gema, em tempo de tragédias ou comédias. Tudo anda envolto, devasso e, o que pior é, não sei se andamos então religiosos com tanto "mata", "mata". E ainda que não fora por outra cousa, senão por se honrarem tirar de obrigações que causam empréstimos neste tempo, seria proveitoso apartarmo-nos disso. E nesta agora, creio ficámos obrigados a meio Portugal com tanto estrondo quanto não sei dizer. E estaremos fora de acontecerem desastres que sempre vi acontecerem aqui em Coimbra nestes ajuntamentos. Na primeira tragédia que aqui vi, ficaram os principais por agasalhar, de que foram agravados. Em outra representação deu um, à porta de casa, com um pau pela cabeça a um estudante bem honrado, e se atribuiu a nós a culpa daquilo. Nesta agora derradeira estiveram para a morte três padres, um clérigo e dois meninos que, ao entrar da porta, perigaram mortalmente. Além disto, ao entrar da porta /152v/, defendendo-a um corregedor por mandado del-Rei, e dando com a vara na cabeça a 
um estudante, que atirou com uma adaga. Pelo qual feito the quisera el-Rei mandar cortar a cabeça por acontecer diante de seus olhos. E foi isto ao entrar del-Rei. E posto que nisto não haja culpa nossa, contudo não se deixa de falar.

Antes de se esta tragédia representar, dous meses, que foram Setembro e Outubro, somente em o tempo dos ensaios sete ou oito irmãos nem livro viram, e estes teólogos, e artistas os mais. Deixemos o tresladar de tantos milhares de versos que tinha a tragédia em que tantos irmãos se ocuparam. E assim com estas quebras e outras semelhantes, creio não sabem os irmãos o que deviam saber.

(...) 
(Página deixada propositadamente em branco) 


\section{SIGLAS, ABREVIATURAS E CONVENÇÕES}

\section{Siglas}

$\boldsymbol{C}=$ Coimbra, BGUC, Cod. 993, fl. 53r-102v: Tragoedia Sedecias acta coram Rege Sebastiano;

$\boldsymbol{E}=$ Évora, BPE, Cod. CXIV/1-9, d, p. 9-154: Tragoedia Sedecias siue de excdio urbis Hierosolymae;

$\boldsymbol{K}=$ Coimbra, BGUC, Cod. 1235, fl. 1r-79v: Tragoedia cui nomen est inditum Sedecias;

$\boldsymbol{L}=$ Tragicae comicaeque actiones a regio Artium Collegio Societatis Iesu datae Conimbricae in publicum theatrum. Auctore Ludouico Crucio. Lugduni, apud Horatium Cardon, 1605, pp. 443-634: Sedecias tragoedia de excidio Hierosolymae per Nabucdonosorem, acta coram Sebastiano Lusitaniae rege, et patruo Henrico ac tota Regni nobilitate;

$\boldsymbol{M}=$ Coimbra, BGUC, M.M70, fls. 98v-105v: [Sedeciae chori quinque];

$\boldsymbol{T}=$ Arquivo Nacional da Torre do Tombo, Ms. da Livraria 2031: Tragoedia de excidio urbis Hierosolymae capto rege Sedecia per Nabuchodonosorem Assyriorum regem.

\section{Abreviaturas}

2.1 - Aparato crítico

add. = addidit

an. $=$ anno

om- = ommisit

cf. $=$ confer

pers. $=$ persona

corr. $=$ correxit

scae. $=$ scaena

eras. $=$ erasit

s. u. = supra uersum

ind. = indicauit

transp. = transposuit

ins. $=$ inseruit

mg. = in margine 


\section{2 - personagens}

ABD. = Abdemelech

AM. = Legatus Ammonitarum

AN. = Ananias;

CH. = Chorus

CL. $=$ Clamor

H. = Hieremias

HI. = Hierias

IVC. = Iucal

ED. = Legatus Edomius

EX. $=$ Exercitus

EXPL. = Exploratores;

FI. MA. = Filius maior

FI. MI. = Filius minor

GED. = Gedelias;

GOD. = Godolias

M. = Miles, Milites;
MOAB.=Legatus Moabitarum;

N. = Nuntius;

NABVC. = Nabucdonosor;

NABVZ. = Nabuzardanus;

NER. = Neregel;

O. = Oraculum;

OP. = Oppidani;

P. = Puer;

PH. = Phassurus;

PR. = Praeco ;

R. = Rex;

SAPH. = Saphatias;

SOPH. = Sophonias;

TY. = Legatus Tyriorum;

V. $=$ Vates .

3. Convenções do aparato crítico

- a barra (/) separa unidades críticas;

- o parêntesis recto (]) separam o lema das variantes;

- o ponto e vírgula (;) une palavras ou expressões ante e post correctionem;

- os expoentes 1 e x indicam respectivamente, a mesma mão ou outras mãos;

- os expoentes 1-2 remetem para a dupla ocorrência do mesmo verso;

- o hífen (-) substitui na palavra-variante a sua parte, inicial ou final, coincidente com o lema;

- os pontos (....) indicam a quantidade de letras ilegíveis por efeito de rasura. 


\section{B I B L I O G RA F I A}

\section{Fontes manuscritas}

\section{Roma:}

Archivum Romanum Societatis Iesu (ARSI), Lus. 52, fl. 89r-90v. (Quadrimestre escrita pelo P. António Rocha).

ARSI, Lus. 59, fl. 5-98 (De uita et moribus Dominici Ioannis libri tres).

ARSI, EPp. NN. 103, fl. 116r (excerto da littera annua referente ao ano de 1570, assinada por Jacobus Fernandes).

ARSI, Lus. 64, fl. 61r-v (Carta do P. Jorge Serrão para o Geral em Roma).

ARSI, Lus. 70 (Cartas do P. Luís da Cruz para o Geral da Companhia).

Coimbra :

BGUC, Cod. 993: Rerum scholasticarum quae a patribus ac fratribus huius conimbricensis Collegii scriptae sunt Tomus secundus.

Évora:

BPE, cod. CXIV/1-9: [Teatro de Luís da Cruz].

Lisboa:

BNL, Cod. 3308: Rerum scholasticarum quae a patribus ac fratribus buius conimbricensis Collegii scriptae sunt Tomus primus.

BNL, Cod. 3234: [Teatro de Luís da Cruz].

ANTT, Ms. da Livraria 2209: Miscellanea.

ANTT, Ms. da Livraria 1963: Thesaurus rerum scholasticarum quae a patribus ac fratribus Collegii conimbricensis scriptae sunt, ab anno Domini 1631 Tomus sextus.

\section{Fontes impressas:}

Bíblia Vulgata

- Bíblia Sacra iuxta Vulgatam Clementinam, noua editio logicis partitionibus aliisque subsidiis ornata a R. P. Alberto Colinga, O. P., Dr. Laurentio Turrado. Tertia editio. Biblioteca de Autores Cristianos, Madrid, 1959. 
Litterae Quadrimestres ex uniuersis praeter Indiam et Brasiliam locis in quibus aliqui de Societate uersabantur Romam missae, MHSI, Madrid-Romam, 1894-1932. 7 vols.

Tragicae comicaeque actiones a Regio Artium Collegio Societatis IESV, datae Conimbricae in publicum theatrum, auctore Ludouico Crucio eiusdem Societatis olisiponensi, nunc primum in lucem editae et sedulo diligenterque recognitae. Cum privilegio. Lugduni, apud Horatium Cardon, 1605.

Franco, A. Synopsis Annalium Societatis Iesu in Lusitania ab anno 1540 usque ad annum 1725, Augustae Vindelicorum et Gaecii, 1726, p. 91.

Leite, Serafim da Silva, ed., Monumenta Brasiliae siue Complementa Azevediana, Roma, Monumenta Histórica Societatis Iesu (MHSI), 1968, vol. V.

Monumenta Paedagogica Societatis Iesu, ed. Ladislau Luckacs, Roma Intitutum Historicum Societatis Iesu, 1974.

Viperano, Giovanni António, Ioannis Antonii Viperani De poética libri três, Antuerpiae, ex. officina Christophori Plantini, M.D.LXXIX.

\section{Traduções:}

Cruz, Luís da, S. I.

- Ludouicus Crucius, Sedecias: Die lateinische Tragödie von Luís da Cruz S. J.. Eingeleitet, herausgegeben un übersetzt vom Matthias Büttner. Peter Lang, Frankfurt am Main, 2004. (Classica et Neolatina Studien zur lateinischen Literatur, 3).

- P. Luís da Cruz, O Pródigo, tragicomédia novilatina. Prefácio, traslado e notas por José Mendes de Castro; introdução e tradução do prólogo por R. M. Rosado Fernandes. Lisboa, INIC - Centro de Estudos Clássicos, 1989. 2 vols (vol. 1: tradução; vol. 2: texto em impressão anastática).

LOYOLA, Inácio de

Constituições da Companhia de Jesus. Trad. e notas de Joaquim Mendes Abranches, S. J., Lisboa, 1975.

\section{Estudos:}

Attollini, G., Teatro e spettacolo nel Rinascimento, Roma - Bari, Laterza, 1988.

Barbosa, Manuel J. S.,

- Bíblia e tradição clássica: a tragédia Sedecias do P. Luís da Cruz, S. I. na convergência duma estética e duma pedagogia. Dissertação de Doutoramento. Lisboa, Fac. de Letras, 1998, Tomo I.

- "Os clássicos e a sua leitura na pedagogia jesuítica. Os Aduersaria de Luís da Cruz, S. I (1543-1604)”, Euphrosyne, 35, 2007, pp. 405-420.

- "Ecos de contemporaneidade na tragédia Sedecias: a questão da guerra" in Luís da Cruz, S. J., e o teatro jesuítico nos seus primórdios. Actas de colóquio comemorativo 
do IV centenário da morte do dramaturgo (1604-2004), Coord. Aires A. Nascimento e Manuel de Sousa Barbosa, Lisboa, Centro de Estudos Clássicos, 2005, pp. 89-101. - "Luís da Cruz e a poética teatral dos Jesuítas: O prefácio que ficou inédito", Euphrosyne 28 (2000), 375-405.

- "Pervivências de Séneca no teatro jesuítico. O caso da tragédia Sedecias de Luís da Cruz" in De Augusto a Adriano. Actas de Colóquio de Literatura Latina (Lisboa, 2000. Novembro 29-30), coord. Aires A. Nascimento, Euphrosyne, Centro de Estudos Clássicos, Lisboa 2002, pp. 221-229.

Bidez, J. e A. B. Drachmann, Emploi des signes critiques. Disposition de l'apparat dans les éditions savantes de textes grecs et latins. Conseils et recommandations. Bruxelles, Secrétariat de l'Union Académique Internationale - Paris, Les Belles Lettres, 1938.

Codima Mir, Gabriel, S. I., Aux sources de la pédagogie des Jésuites. Le "modus parisiensis", Roma, ARSI, 1968.

Companion to Neo-Latin Studies, part I (...), by Jozef Ijsewijn, Lovain, Peeters Press, 1990.

Delumeau, Jean, A Civilização do Renascimento, vol. I, Lisboa, Estampa, 1994, p. 136-138. Cf. Ibid., p. 103.

Franco, António, Ano Santo da Companhia de Jesus em Portugal nas memórias breves e ilustres de muitos homens insignes em virtudes com que Deus a enriqueceu, distribuídas pelos meses e dias de todo o ano, Porto, 1930.

FrÈCHES, Claude-Henri, Le théâtre Neo-latin au Portugal (1550-1745), Paris, Librairie A. G. Nizet - Lisboa, Livraria Bertrand, 1964, p. 241-242.

GRIFFIN, Nigel,

- "Miguel Venegas and the sixteenth-century jesuit school drama", The Modern Language Review, Cambridge 68 (1973), pp. 796-806.

- "A Portuguese Jesuit Play in Seventeenth-Century Cologne", Folio 12 (June 1980), 46-69.

Miranda, Margarida, "Miguel Venegas e Luís da Cruz, S. I.: o mestre e o discípulo" in Luís da Cruz, S. J., o teatro jesuitico nos seus primórdios, cit, pp. 75-88.

PInHo, Ernesto Gonçalves de, Santa Cruz de Coimbra centro de actividade musical nos séculos XVI e XVII, Lisboa, F. Calouste Gulbenkian, 1981.

Pinho, Sebastião Tavares de, "Um códice latino da literatura jesuítica quase desconhecido: o Cod. 1963 da Livraria dos manuscritos dos ANTT", Humanitas 57 (2005) 351-382.

ReEs, Owen, Polyphony in Portugal c. 1530 - c. 1620. Sources from the Monastery of Santa Cruz, Coimbra, Garland Publishing, Inc., New York \& London, 1995. 
Rodrigues, Francisco, S. I., A bistória da Companhia de Jesus na Assistência a Portugal, Porto, 1931-1944, 6 vol.

SpringhetTi, E., S. I., "Un grande umanista Messinese: Giovanni Antonio Viperano. Cenni biografici”, Helicon, I (1961), 94-117.

Veloso, J. M. Queiroz, D. Sebastião, 1554-1578, Lisboa, 1945.

WeInBerg, Bernard, History of literary criticism in the Italian Renaissance, Chicago, University of Chicago Press, 1961.

\section{Dicionários e outras obras de carácter geral}

Biblioteca Lusitana, de Diogo Barbosa Machado, Tomo III, Coimbra, Atlântida Editora, 1966.

Dicionário Enciclopédico da Bíblia, dir. A. Van Den Born, Petrópolis, Ed. Vozes, 1971.

Dicionário de Mitologia Grega e Romana, de Pierre Grimal, trad. de Victor Jabouille, Difel, Lisboa.

Oxford Classical Dictionary, 2a edição, Oxford, University Press, 1970. 
TEXTO E TRADUÇÃO 


\title{
SEDECIAS
}

\section{TRAGOEDIA \\ DE EXCIDIO HIEROSOLYMAE PER NABVCDONOSOREM}

Acta coram Sebastiano Lusitaniae rege et patruo Henrico ac tota Regni nobilitate

Conimbricae

dante Regio Artium Collegio Societatis Iesu

\author{
Auctore \\ LVDOVICO CRVCIO \\ eiusdem Societatis Olisiponensi ${ }^{1}$
}

1 TRAGOEDIA SEDECIAS ACTA coram Rege Sebastiano. Anno 1570, men. Oct. Autore P. ${ }^{\mathrm{e}}$ Ludoico Crucio $\boldsymbol{C}$ Tragoedia cui nomen est inditum Sedecias $\boldsymbol{K}$ TRAGOEDIA SEDECIAS siue de excidio urbis Hierosolymae, capto rege Sedecia, per Nabucodonossorem Assyriorum regem. Acta Conimbricae in Collegio Societatis Iesu coram Sebastiano Luistaniae rege. Spectauit etiam 


\title{
SEDECIAS
}

\section{TRAGÉDIA \\ DA DESTRUIÇÃO DE JERUSALÉM \\ POR NABUCODONOSOR}

Representada diante de D. Sebastião, rei de Portugal, de seu tio D. Henrique e de toda a nobreza do Reino

Em Coimbra

pelo Real Colégio das Artes da Companhia de Jesus

\author{
da autoria de \\ LUÍS DA CRUZ \\ da mesma Companbia, natural de Lisboa
}

$\longleftarrow$ Henriquus Cardinalis regis patruus, et plerique regni principes Antistitesque clarissimi. Autore Ludoico Crucio Societatis Iesu $\boldsymbol{E}$ Tragoedia de excidio Vrbis Hierosolymae capto rege Sedecia per Nabuchodonosorem Assyriorum regem $\boldsymbol{T}$ 


\section{[ACTORVM CATALOGVS]}

ACTORES IN PRINO ACTV

$[p . b]$

- Angelus Solymorum custos, is est prologus. ${ }^{1}$

- Hieremias sacer Dei propheta. ${ }^{2}$

- Puer minister Hieremiae.

- Oraculum diuinum.

- Phassurus militiae princeps Hieremiae inimicus. ${ }^{3}$

- Legatus Ammonitarum ${ }^{4}$

- Legatus Edomius. ${ }^{5}$

- Legatus Moabitarum 6

- Legatus Tyriorum (Hi missi ad Sedeciam arma contra Assyriorum imperatorem mouent $)^{7}$

- Sedecias rex Hierosolymae. ${ }^{8}$

- Ananias (hic aduersus Hieremiam se uatem iactat)

- Iucalus dux ${ }^{9}$ (contra Hieremiam agit)

- Chorus primus

ACTORES IN SECVNDO ACTV

- Hieremias

- Puer Hieremiae

- Ananias

- Oraculum diuinum

- Sedecias rex

- Godolias dux

- Saphatias dux

- Phassurus dux

- Iucalus dux

- Gedelias dux

- Tribunus militum

- Exercitus Sedeciae ${ }^{10}$

- Nuntius qui obiisse Ananiam regi exponit

- Chorus funebris ${ }^{11}$

${ }^{1}$ is - prologus] proloquitur $\boldsymbol{T}^{2}$ Hieremias - propheta] Sanctus Hieremias $\boldsymbol{T}^{3}$ militiae - inimicus] dux Sedeciae $\boldsymbol{T}{ }^{4}$ Amonii Regis legatus $\boldsymbol{T}{ }^{5}$ Edomiae gentis legatus ${ }^{6}$ Moabiti populi legatus ${ }^{7}$ 


\section{[CATÁlOGO DAS PERSONAGENS]}

PERSONAGENS DO PRIMEIRO ACTO:

- Anjo da Guarda de Jerusalém, que faz de prólogo;

- Jeremias, o profeta sagrado de Deus;

- Moço, ajudante de Jeremias;

- Oráculo divino;

- Fassuro, chefe do exército e inimigo de Jeremias;

- Embaixador dos Amonitas;

- Embaixador de Edom;

- Embaixador de Moab;

- Embaixador de Tiro (estes são enviados junto de Sedecias);

- Sedecias, rei de Jerusalém;

- Ananias (este presume de profeta, opondo-se a Jeremias);

- Jucal, comandante (age contra Jeremias);

- Coro primeiro.

Personagens do Segundo aCto:

- Jeremias;

- Moço de Jeremias;

- Ananias;

- Oráculo divino;

- Sedecias, rei;

- Godolias, comandante;

- Safatias, comandante;

- Fassuro, comandante;

- Jucal, comandante;

- Gedelias, comandante;

- Tribuno da milícia;

- Exército de Sedecias;

- Mensageiro que expõe ao rei a morte de Ananias;

- Coro fúnebre.

$\longleftarrow$ Legatus Tyriorum $T{ }^{18}$ Sephonias $\boldsymbol{L}^{19}$ Sapharias $\boldsymbol{C E L}{ }^{20}$ Godolias dux] Phassurus sacerdos add. $\boldsymbol{C}^{21}$ redeuntis] aduentantis $\boldsymbol{K}^{22}$ hostis] Nabucdonossoris $\boldsymbol{K C}{ }^{23}$ imperator] rex $\boldsymbol{K}$ 
ACTORES IN TERTIO ACTV

- Hieremias

- Oraculum diuinum

- Puer Hieremiae.

- Gedelias speculator

- Godolias dux ${ }^{12}$

- Sedecias rex ${ }^{13}$

- Phassurus sacerdos

- Saphatias dux

- Exploratores milites

- Exercitus Sedeciae

- Nabuzardanus militiae Assyriae princeps ${ }^{14}$

- Praeco Nabuzardani

- Oppidani e moenibus ${ }^{15}$

- Nabucdonossor imperator ${ }^{16}$

- Exercitus Assyriorum

- Nuntius.

- Chorus tertius

ACTORES IN QVARTO ACTV

- Puer Hieremiae

- Hieremias

- Custos carceris

- Phassurus sacerdos

- Sedecias rex $^{17}$

- Iucalus dux

- Sophonias ${ }^{18}$ sacerdos

- Oraculum diuinum

- Hierias custos portae Beniamaeae

- Saphatias ${ }^{19}$ sacerdos

- Godolias dux ${ }^{20}$

- Nuntius redeuntis ${ }^{21}$ hostis $^{22}$

- Praeco Sedeciae

- Oppidani ad arma discurrentes

- Nabucdonosor imperator ${ }^{23}$

- Nabuzardanus militiae princeps.

- Chorus quartus

${ }^{12}$ post Godolias dux] add. Comitatus regius $\boldsymbol{K}{ }^{13}$ Sedecias Rex $\boldsymbol{L}{ }^{14}$ Nabuzardanus pers. om. $\boldsymbol{K}{ }^{15}$ e moenibus] e manibus $\boldsymbol{L}$ e muris (muro $\boldsymbol{K}$ ) conclamantes $\boldsymbol{K C}{ }^{16}$ imperator] om. $\boldsymbol{C}$ rex $\boldsymbol{K} \longrightarrow$ 
PERSONAGENS DO TERCEIRO ACTO:

- Jeremias;

- Oráculo divino;

- Moço de Jeremias;

- Gedelias, espião;

- Godolias, comandante;

- Sedecias, rei;

- Fassuro, sacerdote;

- Safatias, comandante;

- Soldados exploradores;

- Exército de Sedecias;

- Nabuzardano, comandante das tropas assírias;

- Arauto de Nabuzardano;

- Cidadãos no alto das muralhas;

- Nabucodonosor, general;

- Exército assírio;

- Mensageiro;

- Coro terceiro.

PERSONAGENS DO QUARTO ACTO:

- Moço de Jeremias;

- Jeremias;

- Carcereiro;

- Fassuro, sacerdote;

- Sedecias, rei;

- Jucal, comandante;

- Sofonias, sacerdote;

- Oráculo divino;

- Jerias, sentinela da porta de Benjamim;

- Safatias, sacerdote;

- Godolias, comandante;

- Mensageiro da chegada do inimigo;

- Arauto de Sedecias;

- Cidadãos acorrendo às armas;

- Nabucodonosor, general;

- Nabuzardano, comandante da tropa;

- Coro quarto.

$\longleftarrow \quad 17$ Rex Sedecias $\boldsymbol{E} 18$ Sephonias $\boldsymbol{L} 19$ Sapharias $\boldsymbol{C E L} 20$ Godolias dux] Phassurus sacerdos add. $\boldsymbol{C} 21$ redeuntis] aduentantis $\boldsymbol{K} 22$ hostis] Nabucdonossoris $\boldsymbol{K C} 23$ imperator] rex $\boldsymbol{K}$ 
ACTORES IN QVINTO ACTV

- Puer Hieremiae

- Hieremias

- Abdemelech Aethiops

- Nuntius Sedeciae ad Hieremiam

- Assyriorum exercitus ${ }^{24}$

- Oppidani ad arma consternati

- Nabuzardanus

- Sedecias fugiens

- Filii duo Sedeciae

- Godolias fugae comes

- Phassurus sacerdos fugiens

- Neregel dux Nabucdonosor

- Rabsaces dux ${ }^{25}$

- Nabucdonosor

- Chorus quintus captiuorum turba

\footnotetext{
${ }^{24}$ Assyriorum exercitus] Chaldaeorum exercitus $\boldsymbol{C}$ Chaldaei $\boldsymbol{K}{ }^{25}$ Nuntius pers. add. $\boldsymbol{K}$
} 
Personagens do Quinto aCto:

- Moço de Jeremias;

- Jeremias;

- Abdemelhec, o etíope;

- Enviado de Sedecias a Jeremias;

- Exército assírio;

- Cidadãos desnorteados, pegando em armas;

- Nabuzardano;

- Sedecias em fuga;

- Dois filhos de Sedecias;

- Godolias, companheiro de fuga;

- Fassuro, sacerdote, em fuga;

- Neregel, comandante de Nabucodonosor;

- Rabsaces, comandante;

- Nabucodonosor;

- Coro quinto, a multidão dos cativos. 


\section{[PERIOCHAE CVNCTORVM ACTVVM]}

PERIOCHA ACTVS PRIMI

Angelus Solymae custos urbem deserit. Isque est prologus. Hieremias cum ministro agit de urbe relinquenda, et scelera exponit. Ex oraculo accipit Hieremias quid sit acturus. /[p.e] Catenas iussus quaerit, quibus captiuitatem praedicit. His Phassurum et legatos externos deterret. Rex Sedecias prauis uatibus obsecundat repulso Hieremia. Ananias est malorum Coriphaeus. Chorus primus.

\section{Periocha Actvs SECVNDi}

Hieremias grauiter conqueritur sequente puero ministro. Ananias inuehitur in Hieremiam. Catenam quam gestabat, abripit, sed monente ex ${ }^{26}$ Oraculo Hieremia se audit moriturum. Sedecias cum proceribus de bello consultat. Duces regem ad arma concitant prohibente Deo per Hieremiam. Regem nuntius turbat, qui exponit Ananiam repente mortuum. Chorus secundus funebris.

\section{PERIOCHA ACTVS TERTII}

Hieremias ex duobus calathis ficorum diuinitus ostensis accipit quid Deus de populo decreuerit. Lagenam luteam iubetur deferre, eamque coram rege frangere. Redit speculator Gedelias: de hoste nuntiat. Tumultuatur rex et proceres, et obstinate arma parant. Hieremias regem conuenit. Cladem imminentem explanat. Sed agitur in uincula, percussus a Phassuro cum lagenam fregit. Milites exploratores certa de hoste aduentante exponunt. Oritur in urbe tumultus. Nabuzardanus primi dux agminis ad muros accedit, deterret obsessos. Postea Nabucdonosor cum mole copiarum propius urbem accedit. Chorus tertius.

\section{PERIOCHA ACTVS QVARTI}

Minister Hieremiae ad carcerem uenit ut uinctum consoletur. Phassurus regis iussu Hieremiam $e^{27}$ carcere mittit. Rex et Proceres laetantur quod soluta obsidione abierit Nabucdonosor contra Aegypti regem Nechaonem. Mittuntur interea ab rege qui consulant Hierem[iam] de summa rerum. Ille praedicit

\footnotetext{
${ }^{26}$ ex ante Hieremia $\boldsymbol{L}^{27}$ a $\boldsymbol{L}$
} 


\section{[RESUMOS DE CADA ACTO]}

\section{RESUMO DO PRIMEIRO ACTO}

O Anjo-da-Guarda de Jerusalém abandona a cidade e faz o prólogo. Jeremias fala com o seu ajudante em abandonar a cidade e expõe os seus crimes. Jeremias fica a saber, pelo Oráculo, o que há-de fazer. Segundo as ordens recebidas, procura umas cadeias com as quais prediz o cativeiro. Por meio delas assusta Fassuro e os embaixadores estrangeiros. O rei Sedecias favorece os maus profetas, rejeitando Jeremias. Ananias é o porta-voz dos ímpios. Coro primeiro.

\section{RESUMO DO SEGUNDO ACTO}

Jeremias solta profundos queixumes, seguido pelo moço ajudante. Ananias lança um ataque contra Jeremias. Arrebata-lhe a cadeia que ele transportava, mas é informado por Jeremias, segundo recomendação do Oráculo, de que vai morrer. Sedecias consulta os nobres sobre a guerra; os generais entusiasmam o rei para a guerra, contra a vontade de Deus revelada por Jeremias. Um mensageiro, ao revelar que Ananias morreu repentinamente, deixa o rei perturbado. Coro segundo: um cortejo fúnebre.

\section{RESUMO DO TERCEIRO ACTO}

Jeremias fica a saber, por dois cestos de figos milagrosamente expostos à vista, o que Deus decidiu sobre o povo. É-lhe ordenado que transporte uma bilha de barro e a quebre diante do rei. O espião Gedelias regressa e dá notícias do inimigo. Alvoroçam-se o rei e os nobres, e preparam afincadamente as armas. Jeremias encontra-se com o rei. Revela-lhe a desgraça iminente, mas é posto na prisão e agredido por Fassuro quando partiu a bilha. Os soldados exploradores dão notícias seguras sobre a chegada do inimigo. Começa a agitação na cidade. Nabuzardano, comandante da linha da frente, aproxima-se das muralhas e assusta os sitiados. De seguida, Nabucodonosor aproxima-se mais da cidade, com o grosso das tropas. Coro terceiro.

\section{RESUMO DO QUARTO ACTO}

O ajudante de Jeremias chega à prisão para consolar o prisioneiro. Fassuro, por ordem do rei, liberta Jeremias da prisão. O rei e os nobres rejubilam por ter sido levantado o cerco e por Nabucodonosor se ter afastado para se defrontar com Necao, rei do Egipto. Entretanto, o rei envia alguns junto de Jeremias, para o consultar 
acie uicto Nechaone, hostem uictorem rediturum. ${ }^{28}$ Hic dum Hieremias in patriam ire pergit, in porta Beniamaea capitur et pro transfuga ${ }^{29}$ habetur. Proceres nequam insontem opprimunt, damnant, uerberant, in carceremque Ionathae trudunt. Redit uictor Nabucdonosor et primum agmen caesorum Aegyptiorum praecisa capita affixa hastis ostentat oppidanis. Chorus quartus.

\section{Periocha Actvs QvinTI}

$[p . f]$

Minister Hieremiae ipsum in tetrum lacum coniectum inuisit. Abdemelech iussu regis inde uatem educit. Nabuzardanus urbem aggreditur. Interim Sedecias rebus iam diffidens fugam cum liberis molitur. Fugit eumque fugientes aliquot consequuntur. Captae urbis nuntio Nabucdonosor approperat. Quaerit quid actum sit de Sedecia. Irascitur ducibus quod euaserit. At ${ }^{30}$ captum cum $^{31}$ ex fuga reductum sciuit, coram datum arguit et liberis iugulatis oculos ipsi effodi iussit. Ita capta urbe et in uinculis habito rege cum captiuis Babylonem abit. Hieremias deflet urbis excidium cui lamentanti chorus captiuorum flebiliter respondet. 
sobre o estado da situação. Ele anuncia-lhes que, uma vez vencido o exército de Necao, o inimigo regressará vitorioso. Nesta altura, ao dirigir-se apressadamente para a sua terra natal, Jeremias é capturado na porta de Benjamim e considerado desertor. Os nobres, malvadamente, oprimem, condenam, vergastam e encerram o inocente no cárcere de Jónatas. Nabucodonosor regressa vitorioso e a vanguarda do seu exército exibe aos cidadãos as cabeças mutiladas dos Egípcios mortos, espetadas nas lanças. Coro quarto.

RESUMO DO QUINTO ACTO

O ajudante de Jeremias visita-o, depois de ele ter sido lançado no lago escuro. Abdemelech, por ordem do rei, retira de lá o profeta. Nabuzardano ataca a cidade. Entretanto Sedecias, não se fiando já da situação, empreende a fuga, na companhia dos filhos. Foge, e com ele vão alguns igualmente em fuga. Com o anúncio da tomada da cidade, Nabucodonosor aproxima-se. Pergunta o que foi feito de Sedecias. Irrita-se com os generais por o terem deixado fugir. Mas quando o soube capturado e trazido de volta, acusou-o diante de toda a gente e ordenou que, degolados os filhos, the fossem arrancados os olhos. Capturada deste modo a cidade e algemado o rei, regressa para Babilónia com os prisioneiros. Jeremias chora a destruição da cidade. Responde aos seus lamentos o coro dos cativos, em pranto. 
Angelvs Solymorvm Cvstos

[p. 1]

\section{Prologvs}

Solymae tuendae maximi imperio dei Custos, minister aliger, tenui diu

Muros superbos urbis, et cladem famis, Belli atque flammae propuli, aeterni furor

5 Dum Regis urbem stare ruituram tulit.

Immensa postquam scelera creuerunt modum

Finesque supra, uindicem sese Deus

Monstrare Solymis statuit, et iniquam solo

Aequare gentem, perfidam, ingratam, suis

Nimis obsequentem sordibus, numquam Deo.

Periere signa, magne Dominator, tua

Et Abrahami posteri silentio

Obliuioso facta mandarunt, tuis

Patrata manibus. Excidit Pharao, excidit

15 Punita flagris impia Aegyptus, rubri

Non in memoriam gurgitis ueniunt aquae,

Hinc inde ituris sicca monstrantes uada.

Non illa nubis umbra caelestis manet

Animis reposita, solis ardentem facem

20 Quae mitigabat. Non per obscurum uagae

Noctis soporem, flammea occurrit pila,

Retinens in ipsa nocte fulgentem diem.

[p. 2]

Non largus unda rupe de dura latex

Extractus, aut diuina uecordem Ceres

25 Commouit animum. Penitus obliti tuae

Diuinitatis, mente de ingrata poli

Eliminarunt fulgura canori ignea,

Cum nube tectus lucida, et toto inclitus

Aethere tonares, cum quadrigarum rotas

$30 \quad$ Auriga ueluti concitares alites.

Aderas Hebraeis, ut Phari inuisae asperum 


\section{Anjo Custódio de Jerusalém}

\section{Prólogo}

Protegendo Jerusalém, às ordens do Deus Supremo, Anjo da sua guarda, ocupei por longo tempo as imponentes muralhas da cidade e dela afastei os flagelos da fome, da guerra e do fogo, enquanto a cólera do Rei Eterno deixou de pé a cidade que se vai desmoronar. Após seus crimes sem conta terem desafiado todos os limites, decidiu Deus castigar Jerusalém, aniquilar esta raça iníqua, pérfida e ingrata, dada em demasia a seus sórdidos crimes, mas nunca a Deus.

Foram-se os sinais da tua presença, Soberano Excelso, e os filhos de Abraão, com seu silêncio, fizeram cair no esquecimento as obras de tuas mãos. Esqueceram o faraó, esqueceram o ímpio Egipto ${ }^{1}$ fustigando-os com o chicote. As águas do Mar Vermelho já não lhes vêm à lembrança, erguendo-se de cada lado dando-lhes passagem.

Já não se lembram da sombra da nuvem celeste mitigando-lhes a fúria do sol ardente.

Já não lhes ocorre a bola de fogo

no sono sobressaltado daquelas noites de errância mantendo, em plena noite, luminosa claridade.

Nem a água jorrando em abundância da rocha dura, nem o pão divino lhes comove a mente delirante.

Esquecidos de todo da tua divindade varreram de sua mente ingrata os fulgurantes relâmpagos do céu sonoro, quando envolto em nuvem, brilhante e solene, soavas em trovões por todo o éter; quando, qual auriga, fazias girar céleres as rodas das quadrigas. Acompanhavas os Hebreus para que estes se furtassem 
Fugerent tyrannum, dura cogentem luto

Opera recocto confici, et uirgis moram

Tergoque luere. Nunc Deo spreto impii

Simulacra facta manibus humanis colunt.

Frondosus ecquis lucus est circum tuos

O Solyma muros, quem peregrinis Deis

Non consecraris? Ara stat montes supra

Vbique multa, uictimae caesae cadunt

40 Et sacra fiunt sculptili, totiens suo

Quod ore fieri uetuit e caelo Deus,

Quem despicata perdite, et frustra fugis.

At te insequetur grauiter ulturus, mouet

Iam iam corusca tela candenti manu,

45 Et arma toto dira iam caelo expedit.

Parere nescis prospera, et amicum Deum

Exosa, falsis applicas mentem Deis.

Scies Baalem, ceteram turbam scies,

Tibi quid uigoris, quidue praesidii ferant.

50 Hostile ferrum, flamma populatrix domos

Agrosque, lata strage uastabit. Ruet

Haec tanta magno Ciuitas casu, neque

Augusta templi maximi penetralia

Hostis furorem barbari auertent. Cadet

55 Hoc peruetustum gentis Hebraeae decus,

Magno dolore ciuium. Templum impiis

Odere factis pace florente, et truci

Demoliente rege clamabunt : "Deus

Sucurre templo, numini est sacrum tuo".

60 O peruicaces, dum stetit pietas, stetit

Templum, et stetisset sancta si pietas procul

Non exulasset. Ite quo ritus sacri

Abiere, pulsi iamdiu facinoribus.

Religio non est patria, et uos ferent

65 Patrii Penates? Ite, qui uestri iugum

Ferre abnuistis principis, saeui modo

Iugum tyranni ferte. Qui sit mitior

33 confici] perfici $C \mathbf{3 4}$ post luere add. 22 uersus KC (vide infra "Appendix I") 38 consecraris] dedicaris $K C T$ / supra] super $K C T \mathbf{3 9}$ cadunt] occidunt $K C T \mathbf{4 1}$ e caelo] aeternus $K C T \mathbf{4 3}$ At] Sed $K C T$ / insequetur] sequetur KCT insequitur L / eras. gla ante grauiter 44 candenti corr. ex -di $\mathbf{4 6}$ prospera] prospere $K C \quad \mathbf{4 8}$ Baalem] Baal ac $C \mathbf{4 9}$ ferant] ferat $K$ 
à cruel tirania do odioso Egipto, que os forçava

ao duro trabalho de cozer o barro e com chicotadas no dorso

castigava-lhes a lentidão. Agora, desprezando o seu Deus

adoram impiamente imagens fabricadas por mãos humanas.

Existirá bosque frondoso ao redor de tuas muralhas, Jerusalém, que a deuses estrangeiros não tenhas consagrado? Sobre os montes, por todo o lado, erguem-se numerosos altares; tombam vítimas imoladas, fazem-se sacrifícios a imagens, coisas proibidas por Deus com sua palavra lá do céu, Deus de quem agora foges, infamemente e em vão, após o desprezares. Mas ele virá no teu encalço para te castigar com dureza.

Ei-lo que já brande, com mão ardente, os dardos cintilantes, e já apresta suas armas terríveis na vastidão do céu.

Não sabes submeter-te a bem e detestando a amizade de Deus viras teu coração para os falsos deuses.

Conhecerás Baal, ${ }^{2}$ conhecerás a restante turba, ficarás sabendo que força e segurança eles te dão.

Armas inimigas, chamas devastadoras assolarão casas e campos, em larga carnificina.

Com enorme estrondo ruirá esta cidade tão grandiosa e nem os sagrados recintos de seu templo-mor afastarão a fúria do bárbaro inimigo. Cairá esta velha glória da nação hebreia, com grande mágoa do povo. Com práticas ímpias detestaram o templo quando a paz florescia, e quando o rei impiedosamente o demolir, clamarão: "Deus, socorre teu templo, consagrado ao teu poder".

Obstinados! Enquanto se manteve a piedade, manteve-se o templo e manter-se-ia, se não tivessem banido para bem longe a santa piedade. Ide para onde foram os ritos sagrados, expulsos há muito pelos vossos crimes.

A religião não é a dos vossos pais e hão-de suportar-vos Os Penates ${ }^{3}$ da vossa pátria? Ide. Não quisestes suportar o jugo do vosso soberano, suportai agora

o jugo dum tirano cruel. Ficai a saber quem é mais brando:

— 53 Augusta] Augusti $K \quad \mathbf{5 4}$ barbari] turbidi KCT $\mathbf{5 6}$ Magno] Summo KCT $\mathbf{5 9}$ Succurre templo] Deus sucurre templo $K \mathbf{6 2}$ ritus] ritu $C \mathbf{6 3}$ crimine et eras. iamdiu s.u.] crimine et $K C T \mathbf{6 4}$ et uos ferent] nec uos patrii $K C T$ et uos patrii $E \mathbf{6 5}$ Patrii] Ferent $E$ ferant $K C T \mathbf{6} \mathbf{6}$ Ferre abnuistis principis] Dei abnuistis ferre $K C T$ / saeui] truculenti $K C T$ 
Deus, an tyrannus, sceptra qui tenet supra

Babylonis arces, discite. Hic fastus graui

70 Vestros retundet dextera, et collo inseret

Victor catenas. Compede includet pedes.

Squalente dabitis carceris nigri situ,

Labore, uirgis, caede stultitiae impiae

Poenam cruentam. Cerno uallari undique

75 Murum corona militum. Circunstrepit

Chaldaeus armis populus. En lucent faces,

Quibus superba tecta Solymorum ruent.

[p. 4]

Iam nuda uibrat arma terribilis manu

Nabucdonosor bellica; tellus sonat

80 Equitum, et equorum millibus pulsa horridis.

O urbis atrox, misera, funesta, at decens

Condicio. Talem uicta uictorem feres,

Qualem furore raptus incenso Deus,

Et prouocatus mole facinorum impia,

85 Armauit in te. Rege sub tali manet,

Quicquid tyrannus uictor in uictos potest.

Et quid timere uictus ex illo potest,

Quem uoluit esse sceleris ultorem Deus?

Vos nunc rebelles principes, duri, asperi,

90 Virtutis hostes, infimae plebi graues

Et innocentum certa pernicies, manus

Armate ferro, fidite iuuentae; arduas

Tenete turres, alta propugnacula

Erigite, muros addite ad muros, caua

95 Munitiones eia fossa cingite.

Cristis superba capita Puniceis fero

Ostendite hosti, pectus ac umerum aeneo

Thorace fortem reddite, et uictoriam

Sperate laeti. Vester in cassum labor

100 Abibit omnis. Patriam belli tegit

Non apparatus. Vna potuisset bene

Seruare pietas, si modo in Solymis foret,

Sub Ezechia fulsit ut quondam, aliger

Quando minister optimi et amici Dei,

68 tyrannus] superbus $K C T$ / supra] super KC $\mathbf{6 9}$ Babylonis Arces] Babylona princeps KCT / discite] dicite $T \mathbf{7 1}$ Victor] ferri $K C T \mathbf{7 2}$ Squalente] Squalenti $K \mathbf{7 5}$ add. en ante circunstrepit KCT $\mathbf{7 7}$ ruent] cadent KCT $\mathbf{7 8}$ terribilis] terribili $K \mathbf{7 9}$ bellica] bellicum $K \mathbf{8 2}$ Condicio] fortuna 
se Deus, se o tirano que detém seu poder

sobre as praças-fortes da Babilónia. Agora, ele quebrará vosso orgulho com sua dextra temível e, vitorioso,

pôr-vos-á cadeias ao pescoço, prender-vos-á os pés com grilhões.

No recanto sombrio dum negro cárcere, castigará sem dó

vossa ímpia insensatez, com trabalhos,

vergastadas e morte violenta. Vejo grupos de soldados

abrindo trincheiras em redor das muralhas. Em redor, o povo caldeu

faz ouvir o estrépito das armas. Já brilham os archotes

que farão ruir os imponentes palácios de Jerusalém.

Com sua mão poderosa, Nabucodonosor já brande, terrível,

sua espada faiscante. A terra ressoa,

batida por multidão assustadora de cavalos e cavaleiros.

Oh! Sorte atroz e miserável a desta cidade! Sorte funesta

mas merecida! O vencedor a que te sujeitarás, depois de vencida,

foi Deus quem o armou contra ti, tomado de cólera violenta

e desafiado pela grandeza sacrílega de teus crimes.

Sob o domínio de tal rei, espera-te aquilo

de que é capaz um tirano festejando vitória sobre os vencidos.

E que poderão os vencidos recear

de quem Deus quis que fosse o vingador dos crimes?

Agora, príncipes rebeldes, cruéis, intratáveis, ${ }^{4}$

inimigos da virtude, severos para com o povo humilde,

flagelo certo dos inocentes, empunhai a espada,

confiai na juventude; ocupai as altas torres,

erguei poderosos baluartes,

duplicai as muralhas, vamos,

cavai em redor trincheiras de fortificação.

Exibi ao feroz inimigo vossas altivas cabeças,

com penachos cor de púrpura, reforçai o peito e os ombros

com couraças de bronze e aguardai, confiantes na vitória.

Todos os vossos esforços serão em vão.

Não é o aparato bélico que protege a pátria.

100

Apenas o poderia ter feito devidamente

a piedade, se ela ainda existisse em Jerusalém,

tal como outrora brilhou, no tempo de Ezequias, ${ }^{5}$

quando o anjo do Deus bom e amigo

$\longleftarrow$ KCT / uicta corr. ex -tam $\mathbf{8 5}$ manet] mane $K \quad \mathbf{8 6}$ tyrannus] cruentus $K C T \quad \mathbf{8 7} \mathrm{mg}$. C / quid] quod $T /$ ex illo] ex eo KCT $\mathbf{8 8}$ sceleris] criminum KCT $\mathbf{8 9}$ Vos] At KCT 92 Armate] Armatae $C$ / ferro] gladiis KCT $\mathbf{9 6}$ superba] decora KCT 99 cassum] casum $C \mathbf{1 0 2}$ in] hic KCT 
105 Sennachyribi copias leto dedit,

Vrbem obsidentes. Rege sub pio et bono

[p. 5]

Defensor urbis praepotens erat Deus.

Sub peruicaci rege Sedecia, et malo,

Portas aperiet urbis, ac hostem afferet

110 Ad auferendos impios ferro et fame.

I nunc et arma scilicet, totis para

Instructa campis, undique uocatas age

In bella turmas, sequere ueloces rotas

Aegyptiorum, quas Deus quondam rubro

115 Te propter hausit aequore. Auxilio tibi

Accerse Iuda, coge finitimos duces,

Et foedera pari iunge consensu: tuas

Spes ludet ultor arce de caeli Arbiter.

Ante Babylonis principem Aegyptus cadet,

120 Socia arma crispans, et Paraetoniis equis

Agens quadrigas, ceu leui uirga caput

Decussa ponunt languidum papauera.

O Rex Hebraei sorte funesta imperi

Sortite culmen! Quem putas hostem tuis

125 Obstare uotis? Credis imperium tibi

Regem inuidere forsitan Babylonium?

Erras: Tonantis obstat irati furor,

Qui regna meritis ut solet uiris dare,

Ita sceleratis demere, et diademate

130 Priuare reprobum regis indigni caput.

Sic sceptra primo regia Sauli dedit,

Sic a nocente rapuit, et regi aemulo

Tribuit Dauidi. Vetera quid repeto? Noua

Sunt quae queramur. Ante Sedeciam duo

135 Male parta regni sceptra tractarunt manu,

[p. 6]

Pater atque natus. Ille Chaldaeo miser

A rege captus, spiritum ferro expuit,

Et insepultus esca uulturibus fuit,

Ac praeda canibus. Vltio secuta impium

140 Non sera tandem est, monita qui uatis sacri

Discerpsit, ac sacrilegus aboleuit rogis.

Sed Ieconias melior infando patre,

$\mathbf{1 0 8}$ peruicaci] peruicace $K \mathbf{1 1 4}$ quas] quos $K C T \mathbf{1 1 7}$ consensu] concensu $K \mathbf{1 3 0}$ Priuare] uiduare $K C T \mathbf{1 3 1}$ regia] rege $K \mathbf{1 3 2}$ regi] rege $K \mathbf{1 3 3}$ quid] cur $K C T$ / repeto] repetis $K$ 
entregou à morte as tropas de Senaquerib

que cercavam a cidade. Sob esse bom e piedoso rei, era Deus omnipotente o defensor da cidade;

sob Sedecias, rei obstinado e perverso,

Ele abrirá as portas da cidade e fará entrar o inimigo

para destruir os ímpios pela guerra e pela fome.

110

Vai, agora, prepara exércitos, claro,

dá-lhes instrução em campos militares, vamos, convoca

batalhões para a guerra, de todo o lado, procura

os carros velozes dos Egípcios afundados outrora por Deus

no Mar Vermelho, em atenção a ti. Em teu auxílio,

chama, Judá, reúne os chefes militares das redondezas;

estabelece alianças por comum acordo:

de tuas expectativas rir-se-á, lá do alto, o Juiz Celeste.

Perante o monarca da Babilónia o Egipto cairá vencido

ao lutar como teu aliado, com cavalos de Paretónio

120

atrelados às quadrigas, tal como, batidas com leve vara, as papoilas deixam cair sua frágil cabeça. ${ }^{6}$

Ó rei do império Hebreu, apanhado por sorte funesta

no esplendor do teu reinado! Que inimigo pensas tu

que se opõe aos teus desejos? Acreditas porventura

125

ser o rei da Babilónia quem inveja o teu poder?

Enganas-te; enfrentas a fúria do Tonante em cólera

que, tal como costuma dar o poder a quem o merece,

igualmente o retira aos ímpios e priva do diadema

a cabeça réproba dum rei indigno.

130

Tal como concedeu inicialmente o ceptro real a Saul, ${ }^{7}$

igualmente o retirou ao rei funesto e o deu

ao seu rival David. Porque vou buscar factos antigos?

Há os recentes para nos lamentarmos. Antes de Sedecias ${ }^{8}$

foram dois a empunhar os ceptros do reino impiamente adquiridos:

135

pai e filho. O primeiro, miseravelmente aprisionado

pelo rei Caldeu, foi morto à espada

e, deixado insepulto, serviu de alimento às aves de rapina

e de presa aos cães. A vingança não tardou a cair

sobre o ímpio que rasgou os oráculos do venerável profeta

140 e sacrilegamente os fez desaparecer nas chamas. ${ }^{9}$

Mas Jeconias, melhor do que o seu nefando pai,

« 134 queramur] conqueramur $K \mathbf{1 3 5}$ tractarunt] gestarunt $K C T \mathbf{1 3 6}$ natus] filius $K C T E$ $139 \mathrm{Ac}]$ Et $K C T \mathbf{1 4 0}$ est] om. KCTE $\mathbf{1 4 2} \mathrm{Sed}]$ At $K C T$ 
Scelere parentis noxius, laetus diu

Non sceptra tenuit. Arma Babylonis tulit

145 Captusque, solio pulsus, abductus domo,

Adhuc profundo carcere inclusus sedet.

Iste Sedecias patruus, euentu pari

Poenas daturus, exitum tandem feret

Acerbiorem. Namque post captam hostico

150 Vrbem labore, dum fuga sibi consulet,

Capietur. Ibit ante uictorem trucem,

Alto sedentem culmine et uictoria

Parta ferocem, liberos cernet suos

Ferro necari. Quam tibi dicam impie

155 Superesse poenam? Liberos postquam tuis

Atrox in oculis carnifex occiderit

Et ora dederit trunca natorum tibi

Spectanda patri, cuspide cruenta eruet

Oculos, ad illam iure seruandos diem

160 Qua, per inimicos patria incensa, necem

Videas tuorum, teque uiduatum tuis

Oculis, triumpho nobili abductum ferat

Victor superbus. Doleo sed casus tuos,

Bone Hieremia, doleo casus. Innocens

165 Ah pro nocente rege, pro gente impia

Quotiens laborem proximum leto feres?

Quotiens malorum principum minacibus

Manibus repulsus, uera non poteris tuis

Denuntiare ciuibus. Quotiens tibi

170 Caedenda pugnis ora? Squalorem lacus

Caliginosi uideo teque sordidum

Horrere caeno. Sic bonos Solymi solent

Habere uates. Crimen est nimium uetus

Maculare sacro sanguine sacrilegas manus.

175 Sed non abibunt perditi aduersus Deum

Impune. Namque feruidae irae iam parat

Laxare frenos. Meque custodem datum

Solymis, abire mandat ad sedem Aetheris.

143 Scelere parentis] Scelereque patris KCT 152 et] s.u. K 155 Liberos] filios KCT 158 patri] gladii $K C T$ / cruenta] cruenti KCT 162 abductum] adductum $L$ / ferat corr. ex -et 164 ante Hieremia $a d d$. o KCT 165 Ah] ah mg. Cx; Ha $C$ / gente impia] plebe impia KCT 
culpado do crime deste, não segurou por muito tempo,

de forma auspiciosa, os ceptros do reino. Suportou as armas de Babilónia.

Aprisionado, deposto do trono, levado de sua casa,

ainda agora permanece detido em escura prisão.

Este Sedecias, seu tio, que sofrerá castigo idêntico, acabará por ter um fim mais amargo:

após as forças inimigas terem tomado a cidade,

será capturado no momento em que tentava a fuga.

150

Será conduzido à presença do cruel vencedor,

sentado em seu elevado trono, de aspecto feroz

pela vitória alcançada, e verá seus filhos

serem passados à espada. Eu te mostrarei, ó ímpio,

o castigo que te espera. Depois de, à tua frente,

o medonho algoz matar teus filhos queridos,

e te entregar à contemplação seus rostos mutilados,

com sua lança ensanguentada arrancar-te-á os olhos,

que deverás conservar até ao dia em que,

incendiada a pátria pelos inimigos, vires o morticínio

160

dos que mais amas, e tu, de órbitas vazadas,

fores conduzido em nobre cortejo triunfal

pelo vencedor orgulhoso. Mas é com tuas desventuras

que eu me aflijo deveras, bom Jeremias. Inocente

perante um rei criminoso, perante um povo sacrílego,

165

quantas vezes enfrentarás perigos de morte?

Quantas vezes, repelido pelas mãos ameaçadoras

dos príncipes perversos, não poderás anunciar

a verdade ao teu povo? Quantas vezes tuas faces

serão açoitadas? Vejo a imundície do tenebroso lago,

vejo-te no meio da lama, coberto de sujidade,

a tremer de frio. Eis como Jerusalém costuma tratar

os seus sagrados profetas. É crime bem antigo o dela,

de manchar suas mãos sacrílegas em sangue sagrado.

Mas não ficarão impunes os que se revoltaram contra Deus,

pois Ele já se apresta a afrouxar os travões de sua cólera fremente.

E a mim, a quem dera a custódia de Jerusalém,

ordena-me que regresse à morada celeste.

$\longleftarrow 166$ proximum leto] morte peiorem $K C T 168$ repulsus] retrusis $C$ retrusus $K T 169$ Denuntiare] Annuntiare $K C T \mathbf{1 7 0}$ ora] membra $K C T \mathbf{1 7 1}$ sordidum] sordido $K C T \mathbf{1 7 6}$ Namque] quoniam $K C T$ / irae iam] iam irae $K C T$ 
O Destituta ciuitas cades, cades.

180 Stat quidquid extat stabile, praesidio Dei.

Qui si recusat ferre praesidium, nihil

Humana possunt arma, nil uires iuuant.

Ego quam reliquit iam Deus, linquo. Volo

Ad alta pennis atria aeterni poli. 
Tu cairás, cidade abandonada, tu cairás.

De pé subsiste tudo quanto se firma na protecção de Deus.

Se Ele recusa seu auxílio, de nada servem

as armas dos homens; serão inúteis os exércitos.

Abandono quem já foi abandonada por Deus. Elevo-me

com minhas asas, voando para as altas moradas do eterno Céu.

$\longleftarrow$ relinquo, quam Deus linquit, uolo $T$ 


\section{ACTVS PRIMVS}

Hieremias. Pver, Minister Hieremiae.

185 H. Regimen senectae, corporis custos mei, Bene fide $a b$ annis primulis gnati loco $O$ educate moribus nostris puer, Alium parentem quaere. Me solum cauas Habitare ualles patere uel saxa asperis Montana siluis. Fugere Solymorum iuuat

Tecta, immo, scelera quae meum inimicant Deum.

P. Auriga miserae gentis ac urbis pater, [p. 8]

Si tu recedis, cui Dei causam tui

Committis homini? Perdite in cladem ruit

195 Si, te monente, Solyma, cum talis uiri

Respectus aberit, uatis alterius minas

Forsan timebit?

H. Spernit ultorem Deum,

Dei ministros audiet? Tuum scio,

Vrbs praua, scelerum mater ingenium scio.

200 Contaminata, foeda, polluta, obruta

Criminibus; alto iura de caelo data

Ipsum et Datorem legis haud pluris facis,

Quam folia uento rapta, quae celeri uolant.

Ego sequar illum profugus inuictum Eliam,

205 Qui Iezabelis fugit insanae minas.

Nam Iezabele ciuitas peior meo

Es facta capiti. Montis inueniam iugum

Alicuius altum, quo Deo tutus fruar,

Vt ille Orebi uertice quieuit senex.

210 Proinde, fili, gradere, genitoris domum

I, quaere propriam. Vita me immemorem tui

Numquam fouebit.

P. Obsecro, mihi es pater.

186 Bene] O KCT 187 O] Bene $K C T 192$ gentis] plebis $K C T$ / pater] iubar $K C T$ 196 aberit] habeat $K C$ abeat $T 194$ Perdite] $m g$. $C 1197$ Forsan] Quasnam $C x T$; Quas non $C$ 


\section{ACTO I}

\section{CENA I: JEREMIAS E O MOÇO SEU CRIADO}

JEREMIAS - Guia da minha velhice, amparo de meu corpo, tão dedicado a mim desde a infância, como um filho. Meu rapaz, por mim educado nos nossos costumes, procura outro pai. Deixa-me sozinho a habitar os vales profundos ou os rochedos das montanhas entre inóspitas florestas. Agrada-me fugir da cidade de Jerusalém, ou antes, dos seus crimes que irritam o meu Deus.

Moço - Ó auriga desta triste nação e pai da cidade, se te afastas, a que homem confias tu a causa do teu Deus? Se, apesar dos teus avisos, Jerusalém se precipita perdidamente na ruína, sem o respeito que lhe inspiras receará ela porventura as ameaças doutro profeta?

Jeremias - Ela despreza o Deus justiceiro.

Ouvirá seus ministros? O teu génio, eu conheço-o bem, cidade depravada, mãe de crimes. Impura, repugnante, suja, mergulhada em infâmias. Às leis emanadas do alto e ao próprio legislador pouca importância dás: não mais do que às folhas que voam movidas rapidamente pelo vento.

Exilando-me, seguirei as pisadas do invencível Elias, ${ }^{10}$ que fugiu às ameaças da insensata Jezabel.

Pior que Jezabel, a cidade tornou-se um perigo

para a minha vida. Encontrarei o cume elevado de um monte

para aí conviver com Deus em segurança,

como o ancião que descansou no cimo do Oreb.

Portanto, meu filho, põe-te a caminho, vai para casa de teu pai, que é a tua. Nunca a vida me sorrirá tendo-me eu esquecido de ti. Moço - Por favor, o meu pai és tu.

$\longleftarrow 205$ minas] impetum KCT 207 iugum] arduum KCT 208 altum] apicem KCT / Deo - fruar] fruar tutus Deo KCT 209 Orebi] $m g$. CX $\mathbf{2 1 2}$ fouebit] fouibit $L /$ mihi] tu add. $K$ 
H. Quid aegra manibus genua complexus tenes Vrgesque lacrimis? Solus ingrediar uiam.

215 Baculo seniles ligneo passus regam.

P. Abire si me praecipis, mori iubes.

H. Sequeris ergo non meos tantum gradus, Sed quae pericla me senem adflictum manent.

P. Deserere cum te morte sit grauius mihi.

220 Perire tecum non grauem poenam puto.

H. O care amori gnate respondes meo.

Agamus at nunc cetera. Huc mentem applica.

P. Ab ore genitor pendeo attentus tuo.

H. Ex quo potentis numen adflauit Dei

225 Hoc pectus aurae flamine supernae igneo,

Vatemque populis esse Iudaeis dedit,

Animum gerendis rebus haud umquam appuli

Quin sciscitarer alma Maiestas polo

E fulguranti quo trahat uatem suum.

230 Ego iussus urbi perfidae, aeterni minas

Iramque cecini Regis. At passim loqui

Mendace dicor ore, nec credunt magis

Ciues monenti pessimi, quam si leuis

Praestigiator nenias agerem foro.

235 Nunc redeo patrio pauca dicturus Deo.

$\mathrm{Me}$, nate, circumsiste, nec hominem sinas

Tumultuantem rumpere inceptas preces.

P. Vigilabo. Precibus et Deo tutus uaca.

\section{HiEREMIAS, ORACVLVM}

Quonam usque populo pergis interitum tuo

240 Afferre, mundi Rector ac rerum Pater?

Stabisne tandem? Iusta cohibebis tuae

Quando arma dextrae? Scelera cum uideo et nouas

Ad uetera culpas crimina effreni adici

Impunitate, dubito quid tecum loquar,

245 Quid pro scelesto rege, pro plebe impia,

Pro facinoroso principum coetu rogem.

$\mathbf{2 1 3}$ aegra - genibus] genua manibus aegra $K C T$ / aegra] $m g$ C $\mathbf{2 1 5}$ ligneo] ut potero KCT $\mathbf{2 1 6}$ si me praecipis] genitor si iubes KCT $\mathbf{2 2 0}$ Tecum perire $K C T \mathbf{2 2 2}$ Agamus - cetera] At (Sed $K$ ) nunc agamus cetera $K C T \quad \mathbf{2 2 8}$ alma] alta $K C T \quad \mathbf{2 3 1}$ at] et $K \mathbf{2 3 3}$ leuis] leues $T$ 
JEREmias - Porque te agarras aos meus débeis joelhos e me incomodas com o teu choro? Seguirei viagem sozinho.

Firmarei meu andar de velho agarrado a um cajado.

Moço - Mandares-me embora é obrigares-me a morrer.

JEREMIAS - Então seguirás não apenas meus passos

mas também os perigos que aguardam este velho angustiado.

Moço - Mais penoso será abandonar-te do que morrer a teu lado.

Não considero grande castigo morrer contigo.

JEREMIAS - Ó meu filho querido, tu respondes à minha afeição.

Mas viremo-nos agora para outras questões. Presta atenção.

Moço - Estou atento às tuas palavras, meu pai.

Jeremias - Desde que a força do poder de Deus

ateou em mim o sopro ardente da brisa suprema

e me destinou como profeta aos povos da Judeia, nunca me preocupei com outra coisa a não ser procurar saber para onde a venerável Majestade, lá do estelífero céu, conduz o seu profeta.

Foi cumprindo ordens que anunciei à pérfida cidade

as ameaças e a cólera do Rei Eterno. Mas em todo o lado

tomam-me por um mentiroso. Não acreditam já em meus conselhos

os depravados cidadãos, como se eu fosse um banal charlatão

recitando fórmulas mágicas na praça pública.

Agora recolho-me para um breve diálogo com o Deus dos nossos pais.

Meu filho, mantém-te por perto e não permitas a ninguém

que interrompa com barulho minhas preces.

Moço - Manter-me-ei vigilante. Entrega-te confiante a Deus e às tuas preces.

\section{CENA II: JEREMias, OrÁCUlo}

Até quando ${ }^{11}$ continuas a trazer a morte ao meu povo,

ó Rei do mundo e Pai do universo?

Pararás algum dia? As justas armas da tua dextra

quando as imobilizarás? Quando vejo crimes

e novas faltas somando-se às antigas,

em total impunidade, não sei que dizer-te;

não sei que pedir por um celerado rei, por uma ímpia plebe,

por uma multidão criminosa de nobres.

— 237 inceptas] ineptas C $\mathbf{2 3 8}$ et - uaca] et uaca tutus Deo KCT 239 Quonam usque] Quocumque $K \mathbf{2 4 0}$ Pater] parens $K \mathbf{2 4 1}$ Stabisne] Sistesne $K C T \mathbf{2 4 3}$ effreni] effrena $K$ 
Omnes in una noxii culpa, tuum

Violare certant numen, et tamquam trucem

Atrox in hostem est facta conspiratio.

250 Discessit animis ille respectus tui,

Quo te priores lege seruata Deum

[p. 10]

Timuere. Praui mente diuersa inquinant

Se se nepotes et, tui obliti, nefas

In omne proni, gentium discunt sacra

255 Et spectra manibus condita artificum colunt.

Mactatur impia impio ritu hostia

Et ture monstris lucus accenso calet.

Oculis qui ista proferat siccis mala?

Aut quis loquendo narret et flendo explicet?

260 Te te repulso patre clemente et Deo

O orbis olim conditi aeternum iubar,

Reges scelesti, poplite incuruo, o Pudor!

Ad arte facta marmora tulerunt preces.

Et inde lapsis rebus auxilium petunt,

265 Veluti careret populus Abrahami Deo.

Quo persequentem uidit in rubro freto

Perire regem, copias haustas aquis

Et deuoratas curribus fractis rotas.

Haec exciderunt facta, sed tantum uiget

270 Cura una sceleris. Hanc auus mandat patri,

Pater nepoti. Nempe ne regi malo

Succedat alter moribus prauis minor.

Non falsa memoro. Vera deploro, meis

Oculis sat hausi. Quanta pernicies scio

275 Reges sequatur impios. Unus modo

Ioachimus alios ante Sedeciam duces

Silere faciet, quem meo numquam Deus

Inflexit ore. Sustulit uates sacros,

Audace mactans dextera, et caedem mihi

280 Impius eadem carnifex struxit uia.

Sed tu micantis Rector Olympi, caput

Pro te cruentae saepe deuotum neci

[p. 11]

Excipere ferrum regis insani horridum

Neque maculari sanguine es passus meo.

248 tamquam] quasi $K C T$ / trucem] improbum $K C T \mathbf{2 5 2}$ inquinant] $m g$. Cx $\mathbf{2 5 7}$ accenso] accensus $K \mathbf{2 5 9}$ explicet] expiet KCT expiet] $m g$. Cx $\mathbf{2 6 0}$ clemente] clementi $K C T \mathbf{2 6 2}$ scelesti] sclesti $L$ / o Pudor] rudes eras, rudes KCT 266 Quo] Qui $K \quad \mathbf{2 7 1}$ nepoti] nepotis $K$ 
Todos igualmente culpados, rivalizam entre si em ultrajar teu poder e, como se tivessem pela frente inimigo feroz, armaram contra ti conspiração implacável.

Varreu-se-lhes da mente aquele respeito por $\mathrm{Ti}$

que fazia os antigos reverenciarem-Te como Deus, cumprindo a Lei.

Corrompidos por nova mentalidade, aviltam-se

os seus descendentes e, esquecidos de Ti,

propensos a toda a impiedade, aprendem cultos pagãos

e adoram imagens feitas por mãos humanas.

Sacrificam-se vítimas sacrílegas em sacrílegas cerimónias

e, queimando incenso, inflamam os bosques com actos monstruosos.

Quem poderá nomear tais desgraças sem chorar?

Quem encontrará palavras para narrar e lágrimas para explicar?

Após te rejeitarem como pai e deus clemente,

ó eterna estrela d'alva do universo outrora criado,

os sacrílegos reis, ajoelhando-se (que vergonha!),

ergueram preces a artefactos de mármore.

E pedem-lhes depois auxílio para as suas aflições,

como se o povo não pudesse contar com o Deus de Abraão.

Foi graças a Este que ele viu morrer no Mar Vermelho

o faraó que o perseguia, seus exércitos engolidos pelas ondas,

as rodas atolando-se, os carros partindo-se. ${ }^{12}$

Mas estes factos ficaram esquecidos e só reina

a obsessão pelo crime. Transmite-a o avô ao pai,

o pai ao neto. Para que a um rei mau, claro, não suceda outro de costumes menos dissolutos.

Não estou a inventar histórias. Deploro verdades

que meus olhos estão cansados de ver. Eu sei de toda a ruína

que reis ímpios podem deixar atrás de si. Apenas um,

275

Joaquim, antes de Sedecias, deixará em silêncio

os outros chefes, ele que nunca se submeteu a Deus,

pelas minhas palavras. Ele fez desaparecer os sagrados profetas,

ousando ordenar que os matassem, e, como carrasco sem escrúpulos,

perpetrou minha morte pelo mesmo processo. ${ }^{13}$

Mas Tu, Soberano do cristalino Olimpo,

Que a minha vida, tantas vezes exposta à morte por causa de Ti,

fosse ceifada pela medonha espada do insensato rei, ou ficasse manchada do meu sangue, isso não o consentiste.

« 272 Succedat] Succendat $C$ / post versum 272 add. 8 uersus KC (vide "Appendix II") $\mathbf{2 8 1}$ Rector] conditor KCT $\mathbf{2 8 2}$ cruentae] s. u. C / saepe] sepe $L \mathbf{2 8 3}$ Excipere] Sentire KCT / regis] Aegis L $\mathbf{2 8 4}$ post hunc uersum add. 10 uersus KC (vide infra "Appendix III") 
285 At nunc iubebis clade Solymorum premi

Aetate fractum, carcere exhaustum senem?

Foris necandum forte, neglectum domi?

Cur pertinace durat haec adhuc gradu

Viuax senectus? Exitum inueniat suum.

290 Sed eamus, anime, quo iubet potens Deus.

Cumque Sedecia sit ferox bellum tibi,

Vt cum scelesto fratre Ioachimo fuit.

Labente curru solis orietur dies,

Quo punietur, ore sic rerum Arbiter

295 Dominusque uitae iussit ut canerem meo.

En intus ignem sentio et motu tumet

Pectus agitatum. Caelitus ferri puto

Imperia magni Regis. En flecto genu.

\section{OraCVlvM Divinvm. HIEREMIAS}

O. Huc ades, interpres diuinae uocis, in urbem

300 Nuntius infidam mitteris et aspera Regi

Inuito mandata feres, qui cogitat amens

Arma inferre Deo gladiisque resistere caelo.

H. Ab arce famulus ardua caeli uocor.

En magne Domitor o superborum, tibi

305 Adsum minister. Quod placet uati impera.

O. Rex Solymae ingratae stultus socia arma rogauit

Finitimos speratque meis ita ludere ceptis.

Armatae contemnit opes Babylonis opimas,

Quas ego iam bellum patefactis ducere portis

310 Efficiam et Solymae se circum effundere muros.

[p. 12]

H. Insanientis Regis est factum, tuam

Qui sperat iram fugere, qui fidit sibi

Suisque turmis, contra ab aetherea domo

Cum detonare dextera ardenti uelis.

315 Si te serenum haberet et amicum Deum

Plebs et Senatus principum ueri inscius,

Rex arma penitus nulla quaesisset foris.

Tu sustineres bella, tu uictoriam

$\mathbf{2 8 5}$ At nunc] Rursus $m g$. $C x$ Rursus $K \mathbf{2 8 8}$ pertinace] pertinaci $K C T \mathbf{2 8 9}$ inueniat] inueniet KC 290 sed] om. K 292 fratre] patre $L \mathbf{2 9 4}$ Quo] Qua $T \mathbf{2 9 6}$ tumet] tument $K C T 297$ Pectus agitatum] Agitata pectora KCT 298 magni] summi $K C T$ / flecto] pono CT prono $K$ 
Obrigarás agora a afligir-se com a destruição de Jerusalém

um velho quebrado pela idade e enfraquecido pelo cárcere, a quem talvez matem fora da pátria, depois de nela o desprezarem? Porque se mantém esta minha velhice com passos bem firmes, ainda tão cheia de vida? Que ela conheça seu fim.

Mas vamos, minha alma, para onde nos manda o Deus poderoso.

Sedecias representará sempre para ti um feroz combate, como aconteceu com o seu sacrílego irmão Joaquim.

Com o deslizar do carro do sol, chegará o dia

em que ele será punido. Eis o que o Juiz do universo

e Senhor da vida determinou que minha boca profetizasse.

Já sinto um fogo por dentro e anima-se de movimento meu peito em agitação. Julgo que me fazem chegar do céu as ordens do grande Rei. Ponho-me de joelhos.

\section{CENA III: ORÁCULO DIVINO E JEREMIAS ${ }^{14}$}

OrÁculo - Aproxima-te, profeta de Deus. À cidade infiel enviar-te-ão como mensageiro e ao rei contrariado duros conselhos darás, a ele que pensa, insensato, pegar em armas contra Deus e desafiar o céu com suas espadas. JEREMIAS - Convocam-me como servidor da excelsa morada celeste. Ó grande Domador dos soberbos, eis-me perante Ti para Te servir. Ordena ao teu profeta o que Te aprouver.

ORÁCUlo - O insensato rei da ingrata Jerusalém solicitou ajuda militar aos povos vizinhos, e espera assim iludir meus planos.

Menospreza as forças militares de Babilónia, muito numerosas.

Farei com que elas levem já a guerra às portas escancaradas da cidade, e se espalhem em redor das muralhas de Jerusalém.

JEREMIAS - O que sucede é obra dum rei louco,

Que espera escapar à tua cólera, confiante em si

e em seus esquadrões militares, quando, ao contrário,

Tu queres fulminá-lo lá da etérea morada com tua dextra fremente.

Se fosses considerado um Deus pacífico e amigo

pela plebe e pela assembleia dos nobres, ignorante da verdade, não teria o rei ido procurar fora quaisquer reforços militares.

Serias Tu a sustentar os combates; serias Tu a dar ao povo 
Sine clade populo lugubri ingentem dares.

320 O. Ergo animis ultro quando fallacibus errant.

Vincula dura tibi et duras molire catenas.

Has collo inicito regique haec munera sunto

Edomio et uafri qui possidet arma Moabi.

Vincula suscipiat simul haec Ammonius, agros

325 Quique Tyri, qui Sidonias dat iura per urbes.

Iam totidem legati aderunt qui nuntia portent, In patriam Solymi redituri ex urbe tyranni.

H. Meo catenas inseram collo, ut iubes.

Sed quae regressis dicta legatis dabo?

330 O. Accipe, nil animo, nil uultu territus aude.

Haec Deus aethereis qui praesidet inclitus astris

Et gentis Deus Isaciae dat iussa: paratis

Vos haurite animis memoresque oracula ferte.

H. Effabor animo fortis excelso, tuum

335 Sed robur adde supplici, o rerum Sator.

O. Nunc age foedifragos homines hoc omine terre.

Haec ait aeternis orbem qui frenat habenis.

Fundamenta potens terrarum ingentia quondam

Ipse manu posui. Per me genus omne ferarum

340 Montibus, at cultis homo uictitat accola terris.

[p. 13]

Fas mihi regna dare et solio deponere reges.

Per me finitimas ergo Babylonius oras

Rex premet imperio et late dominabitur. Illum

Nam famulum dico rerumque in culmine pono.

345 Insuper et uastis habitant quae septa cauernis

Per iuga densa meo flectent animantia iussu

Assyrio collum, uenientque ad iura coacti

Omnigenae populi. Tanti fastigia regni

Transferet in natum uenturi ad saecla nepotis

350 Donec ab Assyrio rerum molimina tollam.

Interea uariae capiant Babylonica gentes

Imperia et magni subdant capita ardua reges.

Si regnum, si plebs aliqua de gente rebellem

Ceruicem extulerit nec dura parauerit acri

355 Colla iugo, super arma fames, et morbida tactu

Eripiet pestis, donec grauis omnia uastem

323 arma] arua KCTE 328 Meo] Ergo KCT 333 haurite] eras. audite et $m g$. haurite Cx audite $K \quad 334$ Effabor - fortis] Erectus animo fabor KCT 336 omine] carmine KCT 337 orbem qui] qui mundum KCT 342 ergo] igitur KCT 346 meo] meos $L /$ animantia] animalia $K$ 
uma vitória gloriosa, evitando a humilhante derrota.

Oráculo - Portanto, uma vez que se enganam a si próprios com ilusões, 320 prepara para ti algemas resistentes e cadeias igualmente resistentes.

Põe-nas ao pescoço e sejam esses os presentes para o rei de Edom $^{15}$ e para o astuto Moab, ${ }^{16}$ dono de exércitos.

Que receba simultaneamente tais algemas o filho de Amon ${ }^{17}$ e o que administra a justiça nos campos de Tiro e nas cidades de Sídon.

Estarão presentes outros tantos embaixadores, portadores de mensagens quando deixarem a cidade do tirano de Jerusalém, de regresso à sua pátria. JEREMias - Porei as algemas ao pescoço, como ordenas, mas que palavras destinarei aos embaixadores no seu regresso? OrÁculo - Ouve, coragem! Que nada te perturbe o espírito e o rosto. Estas são as ordens dadas pelo Deus que preside célebre sobre os astros do céu, o Deus da nação de Isaac: permanecei vigilantes e anunciai os oráculos de Deus sem nada omitir. ${ }^{18}$ JEREMIAS - Falarei com coragem e nobreza de espírito, mas dá força ao teu suplicante, ó Criador do universo. OrÁculo - Agora, vai e atemoriza com este presságio os violadores de alianças. Eis as palavras d'Aquele que com rédeas eternas regula o universo: Eu, com meu poder, firmei outrora a terra sobre grandes fundamentos; é por meu intermédio que toda a espécie de animais selvagens vive nos montes, enquanto o homem se alimenta do cultivo das terras. É-me permitido conceder reinos e depor reis do seu trono. Será, pois, através de mim que o rei da Babilónia exercerá seu poder sobre as regiões limítrofes e dominará sobre um vasto território. De facto, eu chamo-lhe meu servidor e concedo-lhe o domínio do universo. Além disso, até os animais que habitam em amplas cavernas nos cumes arborizados a uma ordem minha dobrarão seu pescoço perante o Assírio, e ver-se-ão forçados a prestar-lhe juramento povos de todo o lado. O esplendor de reino tão poderoso ele o transmitirá a seu filho, até ao tempo de seu futuro neto, ${ }^{19}$ altura em que retirarei ao Assírio o domínio sobre toda a terra. Entretanto, sujeitem-se ao poder de Babilónia vários povos e reis poderosos curvem suas altivas cabeças.

Se algum reino, se o povo de alguma nação orgulhosamente erguer a cabeça e não submeter seu pescoço rebelde à dureza do jugo, dizimá-lo-ão, além da guerra, a fome 355 e uma peste contagiosa, até que eu tudo destrua sem contemplações,

« 351 capiant] capient KC 352 ardua] effera KCT 355 Colla - tactu] Colla iugo - Hunc bellum, tristisque fames, hunc morbida tactu $T 356$ Eripiet] Erip Hunc eras. $E$; Eripiet $E 1$ rapiet $E$ Hunc rapiet $K C$ 
Et gladio Assyrii rubeant late arua Tyranni.

H. Accipio iussa, magne Dominator, tua

Irae tumentis plena. Non uanas minas

360 Agitas, furori nam pares uires habes.

Quantumque poenae iustus exposcit furor,

Tantum seuera cum uoles reddes manu.

Tibi Sedecia tantus extruitur rogus

Qui celsa regni culmina incendet tui

365 Nam contumaci pectore repelles, scio,

Imperia, magnus quae dedit Rector mihi

Ad te ferenda. Durus haud subdes iugo

Fera colla. Namque tu repugnabis manu

Audace, credens posse Babylonis ducem

370 Muris repelli. Teque defensum putas

Iri, receptum regis Aegypti in fidem.

Non nationem seruat Aegyptus tuam.

Quam cum supremus liberam uoluit Deus

A seruitute reddere, inuexit super

375 Aegyptiorum capita tot plagas, fero

Cum rege donec aequore Aegyptum obruit.

O qui sceleribus perditi tentant Deum

Male prouocare. Quem lacessitum suo

Mox imminentem uertici ultorem ferent.

380 Stultitia quanta est generis humani! Mouet

Bellum Tonanti pessimum nec feruidas

Horret sagittas, ille quas certa polo

Morte comitatas fundit et magna opprimit

Quos uult ruina. Perfide, ingrate, impie!

385 Age, Sedecia, terga uerberibus para.

\section{Hierem[ias]. Pver}

H. Pergo, officinam iam catenarum peto.

Ducente puero, publica incedam uia

Ferens catenas aeneas ceruicibus.

Ludens uocabit uulgus insanum senem.

390 Sed quid iocantis sibilus uulgi nocet

359 Irae tumentis] Ira tumenti $C T$ Ira trementi $K 363$ ante extruitur eras. ... $C 366$ magnus] summus KCT 368 Fera - Namque] Tua colla, merito KCT 369 credens] crescens $K$ 377-384 om. $T$; transp. post $362 \mathrm{KC} /$ tentant] te audent $K C \mathbf{3 7 8}$ quem] cum $K C \mathbf{3 7 9}$ Mox] 
e a espada do tirano Assírio tinja de vermelho campos extensos.

JEREMIAs - Ó soberano excelso, acato tuas ordens

possuídas de cólera incontida. Ameaças sérias

proferes, pois teu poder iguala a tua indignação.

E toda a vingança que tua justa cólera reclama, exercê-la-ás quando quiseres, com mão severa.

Ergue-se contra ti, Sedecias, fogueira enorme

que incendiará os pontos mais altos de teu reino,

pois rejeitarás, eu sei, de forma obstinada,

as ordens que o Grande Soberano me incumbiu

de te transmitir. Duro como és, não submeterás ao seu jugo

a tua feroz cerviz. A verdade é que te oporás

com ousadia, pensando ser possível afastar de tuas muralhas

o comandante de Babilónia. E julgas que serás defendido

por te teres aliado ao faraó do Egipto.

Não é o Egipto que salva a tua pátria.

Quando Deus Omnipotente pretendeu

libertá-la da escravidão, lançou

sobre as vidas dos Egípcios grande número de flagelos, ${ }^{20}$

até fazer perecer nas águas o Egipto e o seu cruel faraó.

Ai dos infelizes que com seus crimes ousam impiamente

desafiar a Deus. Bem depressa atrairão sobre si

a vingança daquele a quem desafiaram.

Grande é a insensatez da raça humana!

Move guerra funesta contra o Tonante

e não receia suas setas ardentes, desferidas lá do alto,

mortalmente certeiras, e portadoras de forte ruína

a quem Ele quer. Pérfido, ingrato, sacrílego!

Vamos, Sedecias, prepara as costas para a vergasta.

385

\section{CENA IV: JEREMIAS E O MOÇO}

Jeremias - Dirigir-me-ei de imediato à oficina das cadeias, conduzido pelo rapaz. Meter-me-ei à via pública carregando ao pescoço cadeias de bronze.

O povo, na chacota, apontar-me-á como um velho louco.

Mas que mal fazem vaias e gracejos do povo

$\longleftarrow$ Sint $K C$ / ultorem ferent?] habituri Deum KC $\mathbf{3 8 2}$ polo] e polo L $\mathbf{3 8 5}$ om. KCT 386 Pergo] Hinc $K C T$ / peto] petam KC 388 om. KCT 389 Ludens - senem] Et iam uocabor serio insanus senex $K C \mathbf{3 9 0}$ sibilus] sibulus $K$ 
Facere uolenti iussa mandantis Dei?

Huc fide gressum concita celerem puer.

Habeo catenas, quas meo in collo iubet

Deus ut reponam. Non mihi est ingens onus.

395 Graue Sedeciae et ceteris populis erit.

Age, properemus; nuntia feramus Dei

[p. 15]

Modo quae rebelles, perfidi, insani horreant.

P. Sta, genitor; aures perculit strepitus meas.

Comitatus ingens ad fores urbis sonat.

400 Rex aut superbi Principes ueniunt foras.

Phassurus ante ceteros gressum mouet

Mediusque portam solus ingentem tenet.

H. Inimicus hic est et deo, et legi, et mihi.

P. Ignota facies, habitus aliorum meos

405 Ignotus oculos turbat. Aspectas, pater?

H. Agnosco. Gressum fige. Legatos dedit

Deus alloquendos. Forsitan laeti domum

Rebus secunde et prospere gestis eunt.

Doleant, repugnent. Maesta pro laetis ferent.

410 P. Adeo feroces aggredi est animus tibi?

H. Adesset utinam rex. Dei audisset prior

Mandata et illum uoce non trepida reum

Agerem. Docerem cuius inuisum Deo,

Mille facinoribus esse conuictum caput

415 Ideoque poena legis aeternae graui

Fore puniendum.

P. Sta. Loqui inter se parant.

H. Abeamus istis ut catenas afferam.

\section{Phassvrvs Princeps. Legati RegVm Externorvm}

Ammonivs, Edomivs, Moabvs, Tyrivs.

PH. Mandata regum prospera egistis uia,

Socii fideles. Omnia ex animo domum

420 Vobis referre libere et tuto datur.

Rex arma sequitur uestra Sedecias. Parat

Pugnace contra stare Babylonem manu

$393 \mathrm{in]} \mathrm{om.} \mathrm{KC} \mathrm{393-417} \mathrm{om.} \mathrm{T} 394$ reponam] reportem $K C 395$ et] om. KC / erit] graue $K C \quad 397$ Modo quae] Quae iam $K C \mathbf{3 9 8}$ perculit] impulit $K C \mathbf{4 0 2}$ tenet] occupat $K C$ $\mathbf{4 0 5}$ aspectas] en cernis $K C \mathbf{4 0 6}$ Gressum fige] fili, siste $K C \mathbf{4 0 7}$ Forsitan] forte iam $K C$ 409 Doleant] Quamquam $K C \quad \mathbf{4 1 0}$ feroces] superbos $K C \quad \mathbf{4 1 1}$ audisset] uoces $K C \quad \mathbf{4 1 2}$ Mandata] 
a quem pretende cumprir os preceitos de Deus?

Dirige para aqui, confiante, teus passos ligeiros, meu rapaz.

Tenho as cadeias que Deus ordena que ponha

de novo ao pescoço. Para mim não é carga demasiada.

Pesadas serão para Sedecias e para as restantes nações.

Vamos, apressemo-nos; anunciemos as ordens de Deus

que em breve farão tremer os rebeldes, os loucos, os insensatos.

Moço - Pára, meu pai; chegou-me aos ouvidos som de vozes.

Uma enorme comitiva faz-se ouvir às portas da cidade.

O rei ou os arrogantes nobres estão saindo.

À frente de todos marcha Fassuro

e está sozinho no meio da grande porta.

Jeremias - Esse é inimigo tanto de Deus como da lei e de mim.

Moço - O rosto desconhecido e a estranha vestimenta dos outros

confundem meus olhos. Estás a ver, meu pai?

Jeremias - Percebo. Detém teus passos. Deu-me Deus a oportunidade

de falar aos embaixadores. Dirigem-se a suas casas, certamente,

satisfeitos com o curso favorável dos acontecimentos. Pois que sofram, oponham resistência e em vez de alegrias amarguem tristezas.

Moço - Pensas abeirar-te de gente tão agressiva?

JEREMIAS - Quem dera estivesse presente o rei; seria ele o primeiro a escutar as ordens de Deus. Com voz firme, tratá-lo-ia como um criminoso.

Far-lhe-ia ver que se tornou odiosa a Deus

sua vida manchada por inúmeros crimes,

e que, por isso, deverá ser punido com o severo castigo

da lei eterna.

Moço - Pára. Eles preparam-se para conferenciar entre si.

JEREMiAs - Vamo-nos, para que lhes apresente as cadeias.

\section{CENA V: Príncipe Fassuro E os embaixadores dos ReIS ESTRANGeiros de Amon, Edom, Moab, e Tiro.}

FAssuro - Cumpristes com êxito todas as determinações dos vossos reis, fiéis aliados. É-vos concedido sinceramente, que regresseis a vossas casas em liberdade e segurança.

O rei Sedecias segue os vossos exércitos.

Ele prepara-se para enfrentar Babilónia em duro combate,

— Audiret $K C$ / et] om. L $\mathbf{4 1 3}$ post Agerem] et docerem iudici aeterno suum $K C \mathbf{4 1 5}$ graui] aspera KC $\mathbf{4 1 6}$ PVER pers. om. KC / Sta] Sed KC $\mathbf{4 1 7}$ Abeamus istis ut catenas afferam] eras. Taciti audiamus, quid boni, aut mali ferant et s.u. E Taciti audiamus, quid boni, aut mali ferant KC 420 Vobis referre] Referre vobis $K C T \mathbf{4 2 2}$ Pugnace] Pugnace $C x$; Pugna... $C$ 
Et seruitutis pellere indignae iugum.

Nabucdonosor impotens, quamquam ferox,

425 Viribus et armis poterit armorum graue

Tolerare pondus? Arma tot regum inclita

An franget unus? Tota iam nobis fauet

Aegyptus. Illas axe falcato rotas

Nilum bibentes mittet et equorum greges

430 Velociores Africo et Borea alite.

MOAB. Quid gens Moabi regis optabit magis

Ad bella semper nata quam signum dari

Et classicorum murmur audiri horridum,

Babylona contra barbaram et nostrae inuidam

435 Felicitatis? Arma iam credo rapi

Et magna campis lustra frugiferis agi.

TY. Antiqua longam non trahet moram Tyros, Tyriique proceres. Copiae armatae undique

Propere uolabunt. Odia nam Tyriis nouo

440 Vetusta crescent foedere.

AM. Nec Ammon suos

Populus sub umbra milites tuta sinet Languere. Promptas afferet bello manus.

ED. Sua castra castris ualida coniunget cito Belliger Idumes qui iuuentutem regit.

445 PH. Hac spe superbae iura Babylonis meus

Dura Sedecias spernit et bello adstruit

Regnum tueri liberum, nec singulis

Vectigal annis pendere. O magnum probrum!

Hostemne nostrae mortis et uitae arbitrum

450 Feremus homines liberi? Capiti trucem

Nudabit ensem semper obiecto? Artubus

Tergoque nudo ferreas uirgas dabit?

Mancipia forsan empta Babyloni sumus?

[p. 17]

Quicquid deorum terra uel caelum tenet

455 Ego testor, unus auctor armorum ruam

In bella, quamquam oppetere sit certum mihi.

H. O magne caeli Rector, impietas malo

Ex ore quaenam prodiit! Terrae Deos

Caelique uecors nominat. Montes feram

$\mathbf{4 2 3}$ indignae] infamis $C T$ nefandum $K \mathbf{4 2 6}$ tot] uel $K C T \mathbf{4 2 7}$ An] Tot $K C T /$ iam nobis] nobis iam $K \mathbf{4 3 2}$ semper] penitus $K C T \mathbf{4 3 3}$ audiri] audire $K C E \mathbf{4 3 4}$ barbaram] perfidam $K C T$ 435 rapi] abripi $C x$; abripit $C$ abripi $K T \quad 439$ uolabunt] aduolabunt $K C T$ / hodie $K$ 
e afastar o jugo duma servidão aviltante.

O exaltado Nabucodonosor, ainda que feroz,

conseguirá, com suas tropas e suas armas, suster o ímpeto poderoso

dos nossos exércitos? Os gloriosos exércitos de tantos reis

serão derrotados por um só? Contamos já com o apoio

de todo o Egipto; das margens do Nilo ser-nos-ão enviados

carros de eixos em foice e manadas de cavalos

mais velozes do que o Áfrico e o Bóreas alado. ${ }^{21}$

MOAB - Que mais poderá desejar a nação do rei de Moab, desde sempre dada à guerra, a não ser que seja dado o sinal

e se ouça o terrível som dos clarins

contra a bárbara Babilónia, inimiga da nossa felicidade?

Eu já vejo as armas a serem empunhadas

e grandes sacrifícios expiatórios nos campos de cultivo.

Tiro - A velha cidade de Tiro ${ }^{22}$ não se fará esperar,

nem seus chefes; suas tropas numerosas acorrerão

rapidamente de todo o lado. Esta nova aliança fará renascer

ódios antigos contra os habitantes de Tiro.

Amon - Nem o povo de Amon

permitirá que seus soldados amoleçam sob uma sombra protectora.

Fará avançar para a guerra suas tropas bem treinadas.

EDOM - Juntará sem demora seus poderosos exércitos aos outros

O combativo Idumeu, que comanda a juventude.

FASsURo - É nesta esperança que as duras leis da soberba Babilónia

são desprezadas por Sedecias, meu rei, que assegura, com a guerra,

a manutenção da liberdade do reino e o não pagamento

do imposto anual. ${ }^{23}$ Grande ultraje, este,

ter o inimigo como árbitro da nossa morte e da nossa vida!

Nós, homens livres, toleraremos isto? Ele há-de desembainhar

a cruel espada pondo nossa vida sempre em risco?

Vergastar-nos-á impiedosamente os membros e as costas desnudas?

Somos porventura pertença da Babilónia?

Por tudo o que de divino há no céu e na terra,

juro: eu, o responsável mor dos exércitos,

lançar-me-ei na guerra, ainda que tenha como certo morrer.

JEREMIAS - Ó Soberano excelso do firmamento, que impiedade

saiu desta boca perversa! Os deuses da terra e do céu

são por ele invocados, o insensato! Que montanhas

— 440 crescent] crescunt $K C T \mathbf{4 4 4}$ Idumes] Edomiam KCT $\mathbf{4 5 1}$ obiecto] abiecto KCT/ Artubus] arbutus $K \quad \mathbf{4 5 6}$ bella] arma $K C T /$ oppetere] opetere $C x$; oportere $C \mathbf{4 5 7}$ magne] magnae $L$ 458 quaenam] qualis $K C T$ / Terrae] terret $K C$ 
460 Quinam dederunt tam uenenatam meis

Oculis uidendam?

PH. Sed quis a tergo obstrepit?

H. Turbare mentes, eia, tam fatuas iuuat

Et imminentem corde praesago omnibus

Aperire cladem. Vosne consilia male

465 Male auspicati bella moliri impio

Audetis animo? Classico et uestro undique

Ad arma populos cogere malorum rudes,

Et calamitatis inscios, quae uos trahet,

Vno atque eodem patriam et regna impetu?

470 PH. Haec ominator tristia quis audet loqui?

H. Ego uerus audeo obloqui interpres Dei.

PH. Tune es putandus uerus interpres Dei

An somniorum existimandus artifex?

H. Phassure, nulla somnia, ut iactas, cano;

476 Sed uera caelo monita de supero fero.

PH. Mihi te molestum non pudet factum obuium,

Qui garrientem sat recognoui senem?

H. Est crimen in te iam uetus fidos Dei

Tractare famulos impie, et lingua et manu.

480 PH. O dura, praua, turbida senectus. Fera,

Virum canino quem petis morsu? Meam

Lacessis iram? Iuro frondosis sacra

Celebrata lucis, quos Solyma sacros habet,

Nisi detinerent dexteram externi duces,

485 Iustas daturum caede te poenas mihi.

H. Praeclara uirtus hominis! En capulo tenet

Gladium ac inermem fortis occidet senem.

PH. Praestigiator lucis et uitae bono

Indigne, terrae concauos specus adis,

490 Vt Tartarorum concites umbras truces,

Nigrantis Orci de uaporanti lacu,

Ac deinde caelo dicis e claro tuum

Ipsum Tonantem petere congressum. Ferae

Notate uultus belluae. Tecum Deus

461 Sed quis] Quis meo KCT 462 eia] ergo KCT 464 male] mala $K \quad \mathbf{4 6 5}$ Male] Mala $L$ 466 et $s, u$. 468 quae uos trahet] uosque obruet $K C T \mathbf{4 6 9}$ patriam] patriae $K \quad \mathbf{4 7 0}$ Haec loqui] Quis ominator audet hic praue obloqui? $K C T \mathbf{4 7 1}$ obloqui] loqui $C L \mathbf{4 7 2}$ om. KCT $\mathbf{4 7 3}$ An] O KCT / existimandus] uere falsorum KCT $\mathbf{4 7 6}$ molestum] scelestum KCT $\mathbf{4 7 7}$ sat] te KCT $\mathbf{4 7 9}$ impie - manu] et manu et lingua impie KCT $\mathbf{4 8 0}$ O dura, praua] O praua, dura KCT $\mathbf{4 8 1}$ Virum - Meam] Morsu canino cui aperis hos rictus? KCT $\mathbf{4 8 3}$ quos - habet] urbe 
deram à contemplação de meus olhos 460 fera tão venenosa?

FASSURO - Mas... quem resmunga nas minhas costas?

JEREMias - Vamos! Agrada-me perturbar mentes tão insensatas

e revelar a todos, com espírito profético,

a desgraça iminente. Desorientados por maus conselhos, ousais promover impiamente a guerra?

Ousais, ao som do clarim, alistar à força no exército

povos vindos de todo o lado,

sem noção das desgraças, sem ideia da calamidade

que, num só ímpeto, vos arrastará a vós, à pátria e aos vossos reinos?

FASSURO - Que ave agoirenta ousa falar de tais desgraças?

JEREmias - Ouso eu, o verdadeiro profeta de Deus.

FAssuro - Deveremos julgar-te um verdadeiro profeta de Deus

ou tomar-te por um inventor de fantasias?

JEREMIAS - Não anuncio meras fantasias, como apregoas, Fassuro.

Trago-te, sim, recomendações verdadeiras, enviadas do alto.

FASSURO - Não te envergonhas de me molestares, diante de mim, que te conheço bem como um velho tagarela?

JEREMIAS - É já pecado velho em ti tratares de forma sacrílega os fiéis servidores de Deus, quer por palavras quer por actos violentos.

FASSURO - Ó dura, depravada e transtornada velhice!

Fera! Quem procuras tu atingir com tuas dentadas caninas?

Provocas a minha ira? Juro pelos rituais celebrados

nos frondosos bosques, que Jerusalém considera sagrados:

não fossem os chefes estrangeiros a refrearem a minha dextra

e serias por mim justamente punido com a morte.

485

JEREMIAS - Ilustre coragem a deste homem! Ei-lo a empunhar a espada

para matar corajosamente um velho sem forças.

FAssuro - Charlatão indigno do bem da luz e da vida,

tu encaminhas-te para as profundas cavernas da terra

para agitares as cruéis sombras do Tártaro,

a partir do lago escaldante do negro Orco, ${ }^{24}$

e afirmas depois que é o próprio Tonante, vindo do céu cristalino,

que pretende encontrar-se contigo?

Olhai as feições da feroz alimária. Mistura Deus

Solymorum inclita KCT $\mathbf{4 8 4}$ detinerent] hanc tenerent $K C T \mathbf{4 8 5}$ Iustas - mihi] Poenas daturum morte (mortis $K$ ) te iustas mihi KCT $\mathbf{4 8 7}$ ac inermem fortis] cruentus, languidum $K C T$ 489 concauos] concauae $K C T \mathbf{4 9 0} \mathrm{Vt}]$ Et $K C T$ / concites] concitas KCT $\mathbf{4 9 1}$....ci eras. et Orci s. u. C $\mathbf{4 9 2}$ claro] supero KCT 493 eras. Petere ante Ipsum /Ipsum - Ferae] Petere Tonantem saepe congressum? Ferae (horridae T) KCT $\mathbf{4 9 4}$ eras. consilia miscet post Deus $C$ 
495 Consilia miscet? Si facit, agendi nimis

Est imperitus.

H. Clara rutilantis poli

Septemplici astra quae pererratis face;

Et tu curules flammifer toto rotas

Qui ducis orbe, sol ferens mundo diem;

500 Terraeque lata margine patentes, scelus

Horrete: noster luditur ab isto Deus.

PH. I, querere caeco Tartaro, cuius soles

Simulacra magico deuocare carmine.

H. Quocumque uideor nomine uocandus tibi,

505 Phassure, peior gentibus, quae nesciunt

Huiusce terrae Numen et auitum Deum.

Male sane populi certa decepti lues

Regisque praui. Non tuas timeo minas.

At tu uereri Iudicem aeternum cito

510 Disces coactus.

PH. Morere.

ED. Praecipitem tene

Animum parumper. Neglege insanum senem.

Ne nostra fuso sanguine notetur uia.

PH. Mordacis animam dono non dandam senis.

H. Abitis? At uos alloquor, state, ocius.

515 Age, has catenas regibus uestris damus.

Mea dicta pariter ferte, ne mente excidant.

Ego sum futuros quem docet casus Deus,

Qui uiguit unus semper ac idem uiget,

Oracla cuius ore non falso cano.

520 Vt ille uerus, ore sic uero loquor.

Quicumque bello principem Assyrium petit,

Aut arma contra ferre tentarit, lue,

Gladio, futuram speret aut mortem fame.

PH. Auditis?

AM. Ille similis amenti furit.

525 H. Citius uidebor sanus, illa ferrea

Cum nempe uestras uincula artarint manus.

495 consilia miscet $m g$ C / agendi] prorsus KCT 496 imperitus] otiosus KCT 499 orbe $C x$; orbes C $\mathbf{5 0 1}$ Horrete - Deus] Audite tantum luditur uester Deus KCT $\mathbf{5 0 2}$ querere] sequere $K 503$ deuocare carmine] carmine ciere infera KCT $\mathbf{5 0 7}$ Male] Mala $L$ / decepti] seducti $K C T$ 511 Neglige insanum] mitte delirum $K C T \quad \mathbf{5 1 2}$ Ne] Nec $K \mathbf{5 1 3}$ Mordacis - senis] Vobis ego animam dono mordacis senis KCT $\mathbf{5 1 4}$ At] en $K C T \mathbf{5 1 5}$ Age] En $K C T \mathbf{5 1 9}$ cano] indico KCT 
seus desígnios contigo? Se o faz, é bem ingénuo

em sua acção.

JEREMiAs - Astros cristalinos

do cintilante firmamento que errais com séptupla luz,

e tu, portador da chama, que fazes girar o carro, ${ }^{25}$

dum extremo ao outro do céu trazendo a luz ao mundo;

ó terras que vos estendeis entre extensas fronteiras,

horrorizai-vos com o crime: este homem ridiculariza o nosso Deus.

FAssuro - Vá! Queixa-te ao tenebroso Tártaro, cujos fantasmas

costumas atrair com tuas fórmulas mágicas.

JEREMIAS - Seja qual for o nome por que entendes dever nomear-me,

Fassuro, mais duramente do que as gentes que desconhecem

a divindade desta terra e o Deus dos nossos pais,

tu expiarás, podes crer, os crimes constantes deste povo iludido

e do seu depravado rei. Não receio tuas ameaças.

Mas bem depressa aprenderás à força a recear

o Eterno Juiz.

FASSURO - Morre!

EDOM - Domina por momentos

teu espírito exaltado. Não faças caso dum velho louco.

Que nosso caminho não fique assinalado com derramamento de sangue.

FASSURO - Poupo a vida de um velho mordaz, quando não a deveria poupar.

JEREMIAS - Retirais-vos? Esperai. O que tenho a dizer-vos é breve.

Vá! Oferecemos aos vossos reis estas cadeias.

Levai-lhes igualmente as minhas palavras. Fixai-as bem.

Sou eu quem vos informo do que vai acontecer, o vosso Deus,

que sempre foi e sempre será poderoso.

Não anuncio seus oráculos de forma mentirosa.

Tal como Ele é verdadeiro, também minha boca fala a verdade.

Quem mover guerra ao príncipe Assírio,

ou contra ele se levantar em armas,

espere a morte pela peste, pela guerra ou pela fome. ${ }^{26}$

FASSURO - Ouvis?

AMON - Ele delira como um louco.

JEREMIAS - Bem depressa vereis que tenho juízo quando grilhões de ferro 525 comprimirem fortemente vossas mãos.

« / eras. loquor ante indico $K \mathbf{5 2 0}$ Vt - loquor] Sed ut ille uerus, carmine ita loquar KCT $\mathbf{5 2 1}$ petit] aggredi $K C T \mathbf{5 2 2}$ eras. contra ante tentarit et ins. Contra $m g$. ante ferre $C x \mathbf{5 2 3}$ futuram] cruentam KCT $\mathbf{5 2 4}$ Auditis - similes] Auditis hominem? AM. similis KCT $\mathbf{5 2 5}$ sanus - ferrea] sobrius cum ferrea $K C T \mathbf{5 2 6}$ Cum nempe] illa illa $K C T$ 
TY. Et quis furore saeuiet tanto Deus?

H. Qui te tuosque perdere, ut uolet, potest.

MOAB. Meis litatum credo. Pacati Dei

530 Suis nocere nesciunt cultoribus.

H. Tua non nocebunt spectra, nam lapides colis;

Nisi lapsa forsan te loco e celso premant.

ED. Hic mente captus ille uulgatur senex

Qui terret urbem?

PH. Fabulis pauidum mouet

535 Agitque uulgus. Sed quid hic lento gradu Moramur adeo? Stimulet hunc solum furor.

H. Ite, ite, cladis praescium uestrae senem

Ridete miseri. Quid querar? Nemo ad tuas

Conuertit animum, magne Regnator, minas.

540 Culpa exterorum sed tyrannorum est minor.

Grauiore doleo scelere Sedeciam reum.

Prohibente bellum triste molitur Deo.

Mea dicta flocci pendit, et uoces meas

Sine mente fusas ipse mendax proferet.

545 Agnoscet ille uana sit quantum mihi

[p. 20]

Mens et futuri conscia, ubi Babylon ferox

Aurata circum tecta Solymorum graui

Belli apparatu fixerit tentoria.

Sed quis uirorum prodit e porta globus?

550 PH. Comitatus instat regius. Regem puto

Adesse. Sacras infulas, capitis decus,

Aspicio. Regis sunt sacerdotes. Adest

Rex ipse maiestate regali inclitus.

H. O coetus ille ueste qui niuea albicat

555 Cultumque nitida carbaso corpus tegit

Et nullus animo candor obscuro micat.

Quae uitia pendens infula abscondat, scio.

En contumaces iussa qui spernunt Dei.

Regemque fallunt mollibus dictis suum.

560 Praesente quid me facere Sedecia iubes

Molitor orbis? Teneo, quae mandas, loquar.

Sed rex quid agitet tacitus attendam prius.

527 Ecquis] Et quis CT 529 Meis E1; Meos E / Meis - Dei] Meos litatos habeo placati Dei KCT 533 ille] esse KCT / uulgatur] dictatur K $\mathbf{5 3 5}$ Agitque] Vbique KCT $\mathbf{5 3 9}$ magne] summe

$K C T \mathbf{5 4 0}$ exterorum] ceterorum $L \mathbf{5 4 4}$ Sine - proferet] Sine mente dictas ore sacrilego astruet $K C T \mathbf{5 4 6}$ et] aut $C T$ haud $K /$ ubi] ut $K C T \mathbf{5 4 7}$ graui] asperi $K C T \mathbf{5 4 9}$ prodit] exit $K$ 
Tiro - Mas que deus se irritará com tanta fúria?

JEREMIAS - O que te pode destruir, a ti e aos teus, quando Lhe aprouver.

MoAB - Eu julgo estar em paz com os deuses. Deuses aplacados

não podem fazer mal aos seus adoradores.

JEREMiAs - As tuas imagens não te farão mal, pois adoras pedras,

a não ser que te esmaguem, caindo sobre ti.

EDOM - É este o velho mentecapto de que falam,

que aterroriza a cidade?

FAssuro - Ele impressiona e alvoroça o povo,

que se assusta com suas histórias. Mas porque nos demoramos tanto 535

retardando aqui nossos passos? Que a loucura o atormente só a ele.

Jeremias - Ide! Ide! Ride-vos deste velho que prediz a vossa desgraça.

Miseráveis! Queixar-me de quê? Às tuas ameaças,

ninguém presta atenção, Divino Rei?

Mas a culpa dos tiranos estrangeiros é menor.

Aflijo-me com Sedecias, culpado de crime mais grave.

Contra a vontade de Deus, empreende uma guerra funesta,

pouco caso faz do que digo, e de minhas palavras

dirá, mentindo, serem fruto de desatino.

Ele reconhecerá quão consciente está do futuro

a minha fútil mente quando a feroz Babilónia, com grande aparato bélico, em redor de Jerusalém

e de seus dourados palácios fixar suas tendas.

Mas que multidão de gente é esta que transpõe a porta?

FAssuro - Aproxima-se a comitiva real. Penso ser o rei.

Vêem-se as sagradas ínfulas, ${ }^{27}$ enfeitando as cabeças.

São os sacerdotes do rei. Vem o rei igualmente,

notável em toda a sua real majestade.

JEREMIAS - Oh! Que ajuntamento aquele que alveja de brancos

vestidos, e cobre seus elegantes corpos de branco linho,

quando nenhuma alvura cintila em seus tenebrosos espíritos.

Eu sei dos vícios que se escondem sob a ínfula pendente.

Eis os que obstinadamente desprezam a vontade de Deus

e com doces palavras enganam seu rei.

Que ordenas que faça na presença de Sedecias,

Arquitecto do universo? Estou decidido: direi o que me ordenas.

Mas antes escutarei em silêncio as deliberações do rei.

« 551 capitis] capiti KCT $\mathbf{5 5 3}$ eras. regali ante maiestate $C \mathbf{5 5 5}$ Cultumque] Comptumque $C T$ Quantumque $K /$ nitida] nitido $K T \mathbf{5 5 6}$ micat] emicat $K C T \quad \mathbf{5 5 7}$ pendens] tenuis $K C T$ $\mathbf{5 6 1}$ quae] quod $K C T \mathbf{5 6 2}$ tacitus attendam] audiam attente KCET 


\section{Rex Sedecias. Vates Mendaces. Hieremias}

R. In turbulento proximi belli metu

Subitoque motu, quod bonum et faustum reor

565 Habeo paratum. Scilicet reges mei

Comites laboris integra mecum fide

Ad arma uenient, copias certo ferent

Numero coactas. Vna nunc animo sedet

Infixa cura: ne bona spe et uiribus

570 Concepta retro agatur hinc uictoria

Inque Babylonis castra barbaricae migret.

Valet equitatu, pedite robusto ualet

Nabucdonosor; nostra non torpet manus

Et gnara belli est. Fortia ad Martem mea

575 Pectora iuuentus monstrat ac iam congredi

Hostemque poscit barbarum uotis dari.

Me seruitute liberum reddam graui,

Parere domino desinam Assyrio. Caput

Hoc sustinere pudeat alienum iugum.

580 Habebor urbis huius et regni potens

Dominator ampli. Seruus et supplex emam

Auro quotannis improbam pacem meo?

Audace tandem mihi rebellandum est manu.

Ferrum tenente uera pax emitur manu,

585 Non seruiendo barbaris. Rex sum. Meum

Est imperare munus et leges dare,

At non iugum seruile captiuum pati.

Pelle Sedecia turpe si rex es iugum,

Quamquam resistat senior interpres Dei,

590 Qui forte capitis somnia exponit sui.

H. Patientia mea uincitur. Regi impio

Male sapienti trepidus occurram senex.

Ades o auitum Numen. En partes tui

Defendo iuris. Vanus hic patrii Dei

595 Et inepta mendax nuntiat uates tibi?

Quis ergo uera? Forsitan scurrae tui

Quibus sepulta et spreta religio iacet?

568 animo] animi $C$ animis $K T 569$ Infixa - uiribus] Infixa cura; uincere est nostrum, retro $K C T \mathbf{5 7 0}$ Concepta - uictoria] agatur $m g E 1$; pellatur $E$ Sublata ne feratur hinc uictoria $K C T 571$ Inque - migret] castra s. $u$. E1; signa $E$ / Atque Babylonis agmina profanae petat KCT $\mathbf{5 7 6}$ poscit barbarum] totis postulat KCT $\mathbf{5 8 0}$ urbis huius] huius urbis KCT $\mathbf{5 8 3}$ est] om . KCT $\mathbf{5 8 4}$ Ferrum tenente] Statuo, cruenta KCT $\mathbf{5 8 5}$ Non - Meum] Non seruiendo regibus 


\section{CENA VI: Rei Sedecias, Falsos Profetas e Jeremias 28}

REI - Entre inquietações e receios e o súbito alvoroço

advindos da iminência da guerra, preparei o que julgo

ser bom e oportuno. Certamente que os reis,

meus aliados nesta empresa, me acompanharão na guerra

com inteira fidelidade e trarão consigo

um certo número de tropas. Agora, em meu espírito

reside apenas uma preocupação: que a vitória planeada

com tanta confiança e empenho nos fuja

570

e transite para os acampamentos da bárbara Babilónia.

Nabucodonosor possui forte cavalaria e infantaria;

nossas tropas não se encontram destreinadas

e têm experiência da guerra. Meus mancebos

estão bem treinados para a guerra e com ânsia de combater

e de ver o bárbaro inimigo cair-lhes nas mãos.

Ver-me-ei livre de penosa servidão

e deixarei de obedecer ao monarca Assírio.

Que minha vida se envergonhe de suportar um jugo alheio.

Considerar-me-ão o poderoso soberano desta cidade

e deste extenso reino. Como escravo e suplicante,

hei-de comprar cada ano, com o meu ouro, uma paz precária? ${ }^{29}$

É forçoso que acabe por revoltar-me corajosamente.

A paz autêntica obtém-se de espada em punho

e não sujeitando-nos aos bárbaros. Sou rei.

585

Minha função é governar e dar leis;

não suportar passivamente um jugo servil.

Se és rei, Sedecias, afasta o hediondo jugo,

ainda que a isso se oponha o velho profeta

que, possivelmente, solta fantasias de sua cabeça.

JEREMIAs - Esgota-se-me a paciência. Abordarei o rei ímpio

na figura dum velho trémulo e pouco sensato.

Assiste-me, ó Deus dos meus antepassados. São os teus direitos

que eu defendo. Este profeta do Deus de nossos pais,

falso e impostor, anuncia-te tontices?

595

Quem te anunciará a verdade? Porventura os teus histriões,

para quem a religião jaz sepulta e abandonada?

Babyloniis KCT $\mathbf{5 8 6}$ Est - dare] Excutere saeuum regis impetum placet $K C T \mathbf{5 8 7}$ om. KCT $\mathbf{5 8 8}$ om. $K C T \mathbf{5 8 9}$ senior] patrii $K C T \mathbf{5 9 0}$ forte] falsa $K C T \mathbf{5 9 2}$ occurram] occurrens $C$ $\mathbf{5 9 4}$ Defendo] deffendo $L$ / Vanus - Dei] falsus a patrio Deo KCT $\mathbf{5 9 5}$ nuntiat - tibi] iussa tibi canet senex KCT $\mathbf{5 9 6}$ Quis - tui] Quis ergo dicet uera? Tu, an uates tui? KCT 
Monstrata rite sacra qui priscis auis

Male sustulistis quique marmoreis Deis,

600 Per urbis huius compita, sacrastis nemus.

Cur abstulistis patriam a regno fidem

Regemque blandiendo fecistis reum?

Seu uera, siue falsa reputentur, tamen

Constante fabor ore, quae fatur Deus.

605 R. Quis te tulisset talia loquentem, nisi

Iste Sedecias esset? Et grauissimum

Permitto cur te uiuere, et talem sino

Animam tueri lucis et solis iubar?

Dic saeua regni Furia, quae altaria,

610 Quos ex lapidibus exprobras nobis deos?

H. En urbis illos aspice comantes tuae

Lucos et aras. Dic quibus diuis litat

Deuota plebs? Statua stat cur aureo

Sacrata uitulo? Cur Baalino rogus

615 Cum ture lectas uictimas pingui cremat?

R. Iussune populus hostias caedit meo

Vitulo aut Baali? Falsa cur regi obicis?

Arasne iussu populus aedificat meo

Aut illa celsa montium scandit iuga?

620 H. A rege uulgus fragile quod fieri uidet, Id credit esse regis imperium sibi.

R. Auditis? Ego rex audio et patiens fero.

Peccata regi plebis insonti dabis?

H. Cum uulgus audax publice admittit scelus,

625 Neque coercetur regis et poenae metu,

Rex peccat ipse, qui potest et non uetat.

Tacendo foeda crimina licere asserit.

Quo maior oris regii et sceptri est nitor,

Maiorque fulgor, cura eo uigilantior

630 Desideratur, ne relegata integri

Seueritate iuris ad scelera impia

Patefiat aditus. Poena quae edicto tuo

Pronuntiata tradidit iustae neci

Sacrilega capita, quae profanarum sacra

[p. 23]

601-602 Cur - reum?] Regem ne tantum gentis Isaciae decet (decus $K$ ) - Maculare famam crimine aeterno suam KCT $\mathbf{6 0 3} \mathrm{Seu}$ - tamen] Seu falsa, siue uera credantur KCT $\mathbf{6 0 4}$ Constante] Audace KCT $\mathbf{6 0 6}$ Iste - grauissimum] Tam mitis esset, ut ego, qui grauissimum KCT $\mathbf{6 0 7}$ cur te] monstrum KCT $\mathbf{6 0 8}$ post bunc uersum $\mathrm{O}$ inquietum, turbidum, insanum caput, add. KCT 609 Dic] Et KCT 610 Quos - deos] Quos expolito marmore effinxi (effinxit C) Deos $K C T$ 
Vós que sacrilegamente acabastes com os sagrados rituais prescritos aos nossos patriarcas e que, pelas encruzilhadas desta cidade, consagrastes o bosque a deuses de mármore, porque fizestes desaparecer do reino a religião de vossos pais e, mediante lisonjas, transformastes o rei num criminoso? Considerem-nas verdadeiras ou falsas, proclamarei sem cessar as verdades que Deus proclama. REI - Quem mais toleraria que afirmasses tais coisas 605 a não ser este teu rei Sedecias? E sendo-me tu tão molesto porque te deixo viver, e consinto que uma vida como a tua contemple o esplendor da luz do sol? Diz, ó cruel Fúria do reino, que altares, que deuses de pedra nos censuras?

JEREMIAS - Olha! Repara nos bosques frondosos e nos altares da tua cidade. Diz-me: a que deuses sacrifica a piedosa plebe? Porque se erguem estátuas consagradas a um bezerro de ouro? Por que razão são queimadas na pira, com incenso e gordura, vítimas escolhidas em honra de Baal? REI - É porventura às minhas ordens que o povo imola vítimas em honra do bezerro ${ }^{30}$ ou de Baal? Porque lanças falsidades contra o teu rei? É a meu mando que o povo edifica altares ou sobe aos cumes elevados dos montes? Jeremias - O que o povo ignorante vê ser feito pelo rei 620 Acredita estar autorizado pelo mesmo rei a fazê-lo.

REI - Ouvis? Eu, que sou rei, ouço e suporto com paciência.

Atreves-te a atribuir a um rei inocente os crimes da plebe?

JEREmias - Quando o povo se atreve a cometer crimes em público e não o inibe o receio de que o rei os castigue,

é o próprio rei quem peca, pois tendo poder para reprimir não o faz.

Ao ficar calado, dá cobertura a crimes hediondos.

Quanto maior é o brilho do rosto e do ceptro reais,

Quanto maior o fulgor, maior é o empenhamento e vigilância

exigidos, a fim de que, por abrandamento do rigor

duma justiça isenta, não se abra caminho

a crimes sacrílegos. Que castigo ditado

por decreto teu entregou merecidamente à morte

vidas sacrílegas que, um pouco por todo o lado,

$\mathbf{6 1 2}$ diuis litat] litat Deis $K C T \mathbf{6 1 3}$ stat cur] cur mittat $C$ cur micat $K T \mathbf{6 1 6}$ caedit] mactat $K C T$ $\mathbf{6 1 9}$ scandit] scandet $K \mathbf{6 2 2}$ Ego - fero] Et ego qui audio quietus fero? KCT625 cohibeturK1; coercetur $K$ / et poenae] aut legum KCT $\mathbf{6 2 6}$ et] si KCT $\mathbf{6 2 7}$ Tacendo] Impune KCT $\mathbf{6 3 2}$ edicto] iussu KCT $\mathbf{6 3 3}$ tradidit] dedidit KCT / iustae] meritae KCT 
635 Abominanda gentium passim audiunt?

Age, ueritati cedis an turbat furor?

R. O Furia nostri pestilens aeui, meas

Cur tundis aures? Perge detestabilis,

Auerte uultum, recipe te quo gentium

640 Numquam memoria uenit et saxis tuum

Os praebe et ipsis trade metuendum feris.

H. Satis inter aspera montium uersor iuga

Rupesque duras. Mollior cautes fuit,

Tangente uirga, quando Mosaea dedit

645 Laticem fluentem. Tu, tui, occlusas Deo

Habetis aures perfidi, ingrati, impii.

R. Iam debuisset tale ab Isacidum caput

Abesse terra. Mucro cur cessat meus?

IVC. Te reprime, ductor inclite Isaciae domus,

650 Ignosce uati. Sanguine imbelli manum

Temerabis?

R. Irae da locum semel meae.

H. O grande facinus, ense truncabis uirum,

Cui leuius est perire, quam leges pati

Iacere patrias, quam suum sperni Deum.

655 R. Qui spernit, o maledice, dic tandem Deum, Praestigiator?

H. Nomen hoc potius decet

Vates ineptos regis eludunt sui

Qui fraude mentem fabulis et somniis.

O rex, parumper redde te quaeso tibi,

660 Et uera blandis auribus tandem feras.

R. Vt uera blandis auribus tandem feram?

Praestabat immo non tibi uitam dare.

Sed utrumque miti natus ingenio dabo

Modo reuereri regium aspectum scias.

665 Adeste, famuli, regiam sellam date.

H. Ab arce nitidi Rector astrifera poli

Haec infit: Audi, fide Hieremia, mone

Cum rege populum. Colla Babylonis iugo

635 Abominanda] Exterminanda $K C T$ / passim] quotidie $K C T \mathbf{6 3 6}$ Age - furor] Ecquid pudore uinceris, an ira tumes? KCT $\mathbf{6 3 8}$ detestabilis] detestabilem $K C T \mathbf{6 4 0}$ tuum] tuas KCT 641 Os - feris] Rabidisque rugas trade metuendas feris KCT $\mathbf{6 4 2}$ Satis] Sat KCT / inter aspera] aspera inter $L \mathbf{6 4 4}$ Mosaea] Mosea $K C \mathbf{6 4 5} \mathrm{Tu}$, tui] tu et tui $K /$ occlusas] obstrusas CT / obtrusas K $\mathbf{6 4 7}$ Isacidum] Isacia KCT $\mathbf{6 4 8}$ eras. Ab... ante Abesse / cur] ne KCT $\mathbf{6 4 9}$ inclite Isaciae] magne regalis KCT $\mathbf{6 5 0}$ Ignosce uati] Et parce uatis $K C T$ / manum] manus $K C T$ 
dão ouvidos aos abomináveis deuses dos pagãos?

Vá, conformas-te com a verdade ou deixas-te levar pela ira?

REI - Ó Fúria pestilenta do nosso tempo,

porque atordoas meus ouvidos? Vai-te, ser detestável; ${ }^{31}$

desvia de mim esse rosto; some-te para onde

nunca houve memória de gente; oferece teu rosto

640

às pedras e mostra-o às próprias feras para elas o recearem.

JEREMIAs - Habituei-me a viver nos cumes bem ásperos das montanhas

e em duros penhascos. A rocha foi mais sensível

quando, tocada pela vara de Moisés,

fez jorrar água. ${ }^{32} \mathrm{Tu}$, a tua gente, vós tendes

os ouvidos fechados a Deus, pérfidos, ingratos, sacrílegos.

REI - Uma pessoa destas já deveria ter sido exilada

da terra dos filhos de Isaac. Porque descansa a minha espada?

JucAL - Domina-te, ilustre chefe da casa de Isaac.

Perdoa ao profeta. Sujarás tuas mãos em sangue

de fraca qualidade?

REI - Dá lugar à minha cólera, duma vez por todas.

JEREMiAs - Grande feito! Matarás à espada um homem

a quem custa menos morrer do que tolerar ver espezinhadas

as leis do seu país e o seu Deus desprezado.

REI - Quem despreza Deus, diz duma vez,

655

Ó charlatão maldizente?

JEREMIAS - Essa designação ajusta-se melhor

aos inoportunos profetas que iludem a mente de seu rei

com mentiras, fábulas e bagatelas.

Ó rei, cai em ti, por momentos, peço-te,

e dá finalmente ouvidos à verdade.

660

REI - Eu dar finalmente ouvidos à verdade?

Melhor seria não te conceder a vida.

Mas, tolerante por natureza, ambas as coisas te concederei,

desde que saibas guardar respeito à presença do rei.

Aproximai-vos, serviçais.Trazei-me o trono real.

665

JEREMIAS - De sua divina cidadela, o Soberano dos céus

declara o seguinte: escuta, fiel Jeremias, adverte o povo

e também o rei. Ao jugo de Babilónia

— 651 Temerabis - meae] Temerare R. furiis da locum semel meis KCT $\mathbf{6 5 2}$ ense - uirum] ense truncare (truncato $K$ ) effero KCT $\mathbf{6 5 4}$ quam - Deum] numen et sperni Dei. KCT $\mathbf{6 5 7}$ post ineptos] fabulis et somniis KCT $\mathbf{6 5 8}$ Qui - somniis] Qui nescientem regis eludunt sui $K C$ 659 O Rex] Animum KCT 662 Praestabat] Praestabit $K /$ non] nec KCT $\mathbf{6 6 4}$ post Modo add. tu $K C T$ / reuereri] uereri $K \mathbf{6 6 6} \mathrm{Ab}$ - poli] Ab arce nitida rector immensi poli $K C T$ $\mathbf{6 6 7} \mathrm{Haec}$ - audi] Sic fatus, inquit $K C T$ / mone] admone KCT 
Blanda patienter subdite, et populo hostium

670 Populus timendo uester obsequium ferat.

Hac lege dabitur uita. Sin minus fames

Et uirulenta pestis occidet domi,

Inimicus autem gladius euertet foris.

En haec catena quae meum collum asperis

675 Reuoluta nodis cingit: a caelo est data

Vt seruitutis indicem causam tuae.

Totidem catenas ipse legatis dedi

Sociis ferendas regibus, quorum nihil

Defensus armis arma Babyloni moues.

680 Regem oro supplex, cur tibi et populo exitum

Male obsequenti quaeris horrendum? Caue.

Cauere poteris. Si peris tuo peris

Abusus animo. Respice tenentem manu

Gladium Tonantem, non semel strictum, sine

685 Quamplurimorum caede uaginae inseret.

R. Fortassis animum dicta flexissent tua

Pariter tonante missa si caelo forent

Nossemque te Tonantis imperio loqui.

H. Deus auctor harum uerus est rerum mihi

R. Ostendat aliis. Pluribus habebo fidem.

H. Ex te require nuntios plures Deus

An destinare debeat? Multos tuas

Tu rex in urbes mittere ministros soles

Commissa an uni iussa sat credis uiro?

695 Tibi licet uno nuntio regni oppida

Agitare et urbes, et modum statuis Deo,

Numerumque signas? Viuet ad nutum Deus

Hominis, an ipse uiuet ad nutum Dei?

R. Recusat ecquis uiuere ad nutum Dei?

700 H. Obtemperare qui Dei iussis fugit.

R. Quae iussa narras?

H. Rursus ut narrem iubes?

Narrare citius facere quam malis queo.

Iustitia nulla, nulla religio tua

In urbe Solyma est. Principes uulgo pares

669 Blanda] Vestra $K C T \mathbf{6 7 0}$ timendo] tremendo $K C T$ timendum $L \mathbf{6 7 4}$ meum - asperis] meo collo est data $K \mathbf{6 7 5}$ om. K $\mathbf{6 7 6}$ indicem] indicet $K C T \mathbf{6 8 0}$ supplex] famulus $K C T$ $\mathbf{6 8 1}$ quaeris] quaeres $K \mathbf{6 8 4}$ sine] graui $K C T \mathbf{6 8 5}$ Quamplurimorum] Sine plurimorum $K C T$ $\mathbf{6 8 7}$ Pariter - forent] Si fulguranti missa de caelo forent KCT $\mathbf{6 8 8}$ Nossemque - loqui] Si te Tonantis noscerem imperio loqui KCT $\mathbf{6 9 1}$ require] requiret $K \mathbf{6 9 2}$ destinare] instituere $K C T$ 
submetei pacientemente vossas vidas;

respeite vossa nação a temível nação dos inimigos.

Nestas condições, ser-vos-á poupada a vida. De contrário,

vossa terra conhecerá a fome e a peste virulenta,

e as espadas do inimigo expulsar-vos-ão de vossas casas.

Repara nesta algema que me envolve o pescoço

com ásperos nós. Foi-me enviada do céu,

para te revelar a causa da tua servidão.

Eu mesmo dei outras tantas algemas aos embaixadores

para que as apresentem aos reis aliados com cujos exércitos,

que em nada te protegem, tu moves guerra contra Babilónia.

Ó rei, imploro-te vivamente: por que razão procuras um fim horrível,

680

para ti e para teu povo, não te submetendo? Tem cuidado.

Poderás precaver-te. Se morreres, morres

por mau uso da razão. Repara no Tonante

segurando o gládio, nem uma só vez desembainhado.

Ele inseri-lo-á na bainha, evitando a chacina de muitos.

685

REI - Talvez tuas palavras alterassem minhas ideias,

Se elas te fossem igualmente enviadas do céu pelo Tonante

e eu soubesse que falavas às ordens d'Ele.

JEREMIAS - É Deus o verdadeiro autor destas minhas palavras.

REI - Que o mostre a outros. Em muitos eu acreditarei.

690

Jeremias - Interroga-te: deverá Deus nomear

muitos mensageiros. Costumas tu, enquanto rei,

enviar às cidades numerosos serviçais

ou acreditas que bastam ordens confiadas a um só homem?

Tu podes ocupar-te, com um só delegado, das fortalezas

695

e cidades do reino, e para Deus estabeleces o procedimento

e indicas o número? Viverá Deus às ordens do homem, ou será este que deve viver às ordens de Deus?

REI - Quem recusa viver sob as ordens de Deus?

JEREMIAS - Aquele que evita conformar-se com os decretos divinos. 700

REI - Que decretos referes tu?

JEREMIAS - Obrigas-me a repetir tudo de novo?

Posso fazê-lo mais rapidamente do que tu o preferirias.

Não há qualquer justiça, qualquer temor de Deus

na tua cidade de Jerusalém. Os chefes são iguais ao povo,

$693 \mathrm{Tu}$ - soles] Forsitan ad urbes mittere ministros soles KCT 694 Commissa - uiro ?] An potius uni iussa committis uiro? KCT $\mathbf{6 9 6}$ Agitare - Deo] Agitare uaria, statuis et normam deo KCT 697 signas] ponis KCT $\mathbf{6 9 9}$ Recusat ecquis] Et quis recusat KCT $\mathbf{7 0 0}$ Dei iussis fugit] fugit monitis Dei $K C T \mathbf{7 0 1}$ iussa] monita $K C T /$ iubes] petis $K C \mathbf{7 0 2}$ malis] uelis $K C T \mathbf{7 0 4}$ In - est] Hac est in urbe $K C T$ 
705 Principibus est par uulgus in facinoribus.

Certamen est in scelere quis pessimo

Victor triumphet nobilis. Fraudes, doli

Stupra et rapinae, feruidae libidines

Ecquam relinquunt publica intactam domum

710 Contagione? Frater in fratrem scelus

Molitur animo perfido. Natos patres

Male procreatos peius in morum malo

Docuere ludo. Sacra diuina omnibus

Polluta non iam lacrimor. Longe obruta

715 Obliuionis scelere pestifero iacent.

E silice, truncis, auro, et argento Deum

Simulacra fiunt. Feminae, uiri, senes

Curuata genua duplicant, tollunt manus,

Vt ante lapidum fragmina effundant preces

720 Rege haec uidente uel iuuante crimina,

Deique terret nullus ultoris timor?

Timete poenam, moneo; non abest procul.

R. Audire uatum soleo legionem et mali

Nihil futurum mente praesaga canunt,

725 Sed laeta referunt patrii ex adytis Dei.

$\mathrm{Tu}$ tam timendum solus excidium uides?

H. Quia solus almi Numinis nomen colo.

R. Quid ergo uates ceteri denuntiant?

H. Quae somniarunt.

R. Magne Dominator, tua

730 Consilia tantum prodis inualido seni?

Quis credet uni?

H. Credidit fidus Dauid

Vni Nathano.

R. Cur mihi uates ferunt

Responsa multi uaria? Si credo tibi, Istos repellam? Dicite, o uates Deum,

735 Si nostis, ecquid magnus in nostram Deus

Molitur urbem laeuus an dexter suum

Potius fauorem rebus in duris dabit?

$\mathbf{7 0 9}$ publica] infera $K C T \mathbf{7 1 1}$ perfido] feruido $L \mathbf{7 1 2}$ malo] schola $K C T \mathbf{7 1 3}$ ludo] turpi KCT $\mathbf{7 1 4}$ lacrimo KCT / post lacrimor add. KCT $\mathbf{7 1 6}$ et] om. K $\mathbf{7 1 8} \mathrm{Vt}$ ] et $K C T \mathbf{7 2 1}$ Deique - timor] Et nulla ueri poena speratur Dei? KCT $\mathbf{7 2 2}$ Timete - procul] Sperate poenam moneo, praedico, assero $K C T \mathbf{7 2 4}$ futurum] futuri $K C \mathbf{7 2 6}$ tam] iam $K$ / timendum] tremendum $K C T$ 
e este igual aos chefes, na prática do crime.

Há rivalidade sobre quem triunfará no crime mais sórdido

como glorioso vencedor. A fraude, o engano,

o estupro, o roubo, a licenciosidade desenfreada,

deixarão alguma casa ao abrigo do contágio público?

O irmão maquina crimes contra o irmão,

de ânimo exaltado. Os filhos impiamente gerados

foram educados ainda pior pelos pais,

em escola de maus costumes. Pelo culto sagrado,

por todos profanado, já nem me lastimo. Há muito o desprezam

em doentio e criminoso esquecimento.

Em pedras, em madeira, em ouro e prata, modelam-se

imagens de deuses. Mulheres, homens adultos, anciãos,

ajoelham-se, erguem os braços ao alto

para derramarem súplicas perante pedaços de pedra.

O rei assiste, apoia mesmo tais crimes,

e não o inibe qualquer receio da justiça divina?

Temei o castigo, aviso-vos; ele não está longe.

REI - É meu hábito escutar grande número de profetas

e nenhum mal eles me pressagiam;

pelo contrário, trazem-me boas novas do santuário do Deus de nossos pais. ${ }^{33} 725$

Só tu é que vês tão temível catástrofe?

Jeremias - Porque só eu venero o nome do Deus Criador.

REI - Que anunciam então os outros profetas?

JEREMIAS - Fantasias.

REI - Ó Soberano excelso, teus desígnios

apenas os revelas a um velho sem forças?

Quem acreditará apenas numa pessoa?

JEREMias - O fiel David

acreditou apenas em Natan. ${ }^{34}$

REI - Por que razão então tantos profetas

me trazem respostas diferentes? Para acreditar em ti

vou rejeitar estes? Dizei, profetas, se conheceis Deus:

será que o Deus poderoso tem em preparação

algo contra a nossa cidade? Está por nós ou contra nós?

Dar-nos-á, na adversidade, seu favor de preferência?

« / excidium] exitium $K \mathbf{7 2 7}$ Numinis nomen] iudicis numen $K C T \mathbf{7 2 9}$ Quae] Quod KC 730 prodis] detegis $K C T$ / inualido] inualido $E 1$; infirmo eras. $E$ egeno $K C T$ in ualido $L$ $\mathbf{7 3 1}$ fidus] sanctus $K C T \mathbf{7 3 4}$ Istos] Cur hos KCT $\mathbf{7 3 5}$ ecquid magnus] aliquis magnus $C$ aliquid magnum KT $\mathbf{7 3 7}$ Potius] Nobis KCT 


\section{VATVM MALORVM TVRBA}

Solymae timenda sceptra qui gestas manu, Exue timorem, uera fatidico damus

740 Tibi corde. Numquam miles Assyrius tuam

Vallabit urbem. Scilicet curas alit

Nabucdonosor asperi belli modo.

Nil ille uoluit pectore infenso minus,

Quam militares aggregat nunc copias

745 In bellicosas gentis Hebraeae tribus.

H. O qui malorum dicta fulgenti uides

De sede regni fulgidi aetherea Arbiter,

Cur serus ultor fulmina et radios tenes

Manuque et ore tandiu mutus siles?

750 Mendace uates infit augurio Dei

Consulta reddo et creditur. Verus fidem

Regi relictam facere seducto nequit.

At non tacebo, uel repugnantem tibi

Regem monebo. Verba falsidici ferunt

755 Inimica uates, fabulas narrant meras.

Nihil ore moniti Regis aeterni canunt.

V. O imperitum, lubricum, et uanum caput!

Fallax, superbum, digna et indigna obloquens.

Tu nempe Moses alter, aethereum Deum

760 Agnoscis, et nos praescio stulti nihil

Animo uidemus? Scilicet solus tenet

$\mathrm{Ab}$ ore uates iste suspensum Deum?

H. O atra Furia, pestis, exitium, lues

Huiusce regni, Regis auersi, et tui

765 Fatale damnum capitis, insane impios

Affers tumultus. Poena mors instat tua.

R. Has serere uerbis quando uos pugnas iuuat.

Rerum potentem qui uidetis arbitrum

Facilemque habetis, quo lubet uultu, Deum

770 Malo moderari quam eripi mentem mihi.

Festinus abeo; pacis et belli meas

Tractabo habenas ducibus et tradam meis.

$\mathbf{7 4 2}$ asperi - modo] feruidi belli asperas KCT $\mathbf{7 4 3}$ infenso] infesto KCT $\mathbf{7 4 4}$ nunc s.u. E / aggregat - copias] copias regni undique KCT $\mathbf{7 4 5}$ In - tribus] Armare contra gentis Isaciae tribus $K C T$ / contra $C 1$; copias $C \mathbf{7 4 6}$ dicta] dictu $L$ / fulgenti] fulgente $T \mathbf{6 4 8}$ fulmina et rádios] arduum caelum KCT $\mathbf{7 5 0}$ infit] inquit KCT $\mathbf{7 5 5}$ Inimica] Inepta KCT / meras] suas KCT 


\section{Turba dos Falsos Profetas}

Tu, que com mão temível empunhas o ceptro sobre Jerusalém, afasta o receio. Apresentamos-te a verdade, ao falarmos-te do futuro. Jamais soldados assírios cercarão com trincheiras tua cidade. Inquietas-te com Nabucodonosor, receoso das proporções que tomará uma guerra cruel?

Cego de ódio, cheio de irritação, ele apenas quis reunir neste momento efectivos militares contra as aguerridas tribos do povo hebreu.

Jeremias - Tu que, como juíz, observas os ditos dos ímpios da cintilante morada celeste do luminoso reino, porque tardas em vingar-te segurando os relâmpagos e os raios e permaneces imóvel e silencioso tanto tempo? O profeta começa a falar mentindo; respondo eu com oráculos de Deus e é nele que acreditam. Quem fala verdade não consegue inspirar ao rei corrupto um mínimo de confiança. Mas não me calarei. Mesmo opondo-se a ti, admoestarei o rei. Os falsos profetas proferem palavras malfazejas, narram meras fábulas.

Nada do que dizem é recomendado pelo Rei eterno.

Profeta - Ó cabeça ignorante, volúvel e mentirosa!

Matreiro, arrogante, interrompendo-nos com palavras dignas e indignas!

Será que, como outro Moisés, conheces o Deus supremo, sendo nós apenas uns insensatos, que nada vemos

com espírito profético? Será que apenas este profeta

traz Deus suspenso de sua boca?

Jeremias - Ó Fúria negra, peste, flagelo, epidemia, deste reino, do rei transviado e de ti próprio ruína fatal, insensato, tu provocas ímpios tumultos.

A morte espreita-te como castigo.

REI - Uma vez que vos agrada alimentar tais discussões, a vós que vedes o poderoso juiz do universo e o tendes como um Deus condescendente, conforme vos apraz, eu prefiro moderar meu espírito a deixá-lo arrebatar-se.

Retiro-me sem mais demora; tomarei as rédeas da paz e da guerra e entregá-las-ei aos meus generais.

756 Nihil] Non $K C T$ / moniti] monita $K$ / aeterni] excelsi $K C T \mathbf{7 6 5}$ insane] insani $K$ $\mathbf{7 6 6}$ Affers] Renouas $K C T$ / instat] fiet $K C T \mathbf{7 6 7 - 7 6 8}$ Has - Deum] Has immodeste serere uos pugnas decet - $\mathrm{O}$ qui loquentem et facilem habetis iudicem - Caeli micantis, ipse regalem domum KCT $\mathbf{7 7 0}$ om. KCT $\mathbf{7 7 2}$ Tractabo - meis] Mihi sumo curas, ducibus et tradam meis. KCT 
Quis hic Tonantem credat e caelo loqui?

Hic ominatur tristia, hic autem bona.

775 Incerta potius uela fortunae dabo.

Euentus illa prosper, ut spero, reget.

H. Ito, ito, sancta respue hortantem senem.

Non sera ueniet languido passu dies

Doctura cunctos uera quis ueri Dei

780 Mandata tulerit. Ite diuini nigro

Orco aptiores. Me reliquerunt foris,

O summe rerum Conditor. Praeceps agam

Quo me dolentem? Clamo ceu praeco in foro

Et in urbe tota, sibilus uulgi excipit

785 Stultaeque risus plebis. Heu magnum scelus!

Rex ipse, falsis credulus, durus tibi est.

Quo me ergo fractum, debilem et spretum trahis?

O me grauatum tot malis, uitam iube

Finire tristem, et pace canos perdita

790 Inferre tumulo. Restat hoc unum: mori.

At cur querelas semino? Ingrediar forum

Audace lingua proferam cladem, tuus

Quam destinauit animus. Attentas semel

Fortassis aures saepe conclusas dabunt.

\section{ChORvs Primvs}

\section{Asclepiadeum Carmen}

795 Reges qui populis iura timentibus

Formidanda datis, discite credulam

Aurem falsidicis non dare uatibus.

Luctum namque grauem saepius afferunt,

Auditi quotiens somnia nuntiant

800 Insani capitis quae male contegunt

Mendaces superi nomine Numinis.

Culpa decipiunt nec sine principum.

Nam quaecumque suis sensibus appetunt,

773 e caelo] immensum KCT $\mathbf{7 7 4}$ autem] uates KCT $\mathbf{7 7 6}$ Euentus - reget] Vbi tanta uates occupat contentio KCT $\mathbf{7 7 9}$ eras. Quae ante Doctura / Doctura cunctos] Quae te docebit KCT / quis] qui $K \mathbf{7 8 1}$ Me - foris] Solus en maneo foris $K C T \mathbf{7 8 4}$ tota] media KCT $\mathbf{7 8 5}$ Stultaeque 
Quem acreditará aqui que o Tonante falou lá do céu?

Um pressagia acontecimentos funestos; outro, auspiciosos.

Prefiro navegar na incerteza da fortuna.

Ela conduzirá os acontecimentos a bom termo, assim espero.

Jeremias - Seja! Seja! Despreza um ancião que te exorta santamente.

Virá, não tarda, com passos vagarosos, o dia que a todos mostrará

quem anunciou as verdadeiras recomendações

do Deus verdadeiro. Ide-vos, adivinhos,

tão simpáticos ao negro Orco. Marginalizaram-me,

Supremo Criador do universo. Para onde me virarei

na minha aflição? Clamo em voz alta no foro

e na cidade inteira, chovem sobre mim os apupos da populaça

e os risos da insensata plebe. Oh! Que crime monstruoso!

O próprio rei, fiado em falsidades, é cruel para contigo.

Para onde me arrastas então, enfraquecido, débil e desprezado?

Pobre de mim, atormentado por tantos males! Ordena

que se acabe esta minha triste vida e, perdida a paz,

dá sepultura a estes cabelos brancos. Só me resta morrer.

790

Mas porque solto queixumes? Entrarei no foro

e anunciarei corajosamente as desgraças

por Ti destinadas. Talvez ouvidos tantas vezes fechados

prestem por uma vez atenção.

\section{CORO I}

\section{Canto Asclepiadeu}

Ó reis, que a povos que vos temem, 795 impondes leis temíveis, aprendei

a não acreditardes facilmente nos falsos profetas.

A verdade é que revelam em geral profunda mágoa

quando os escutam anunciando fantasias

de seu espírito insensato, impiamente dissimuladas

com fingidas invocações do Deus altíssimo.

Nem enganam sem a conivência dos nobres,

pois tudo o que se aproxima de suas ideias

« risus] Risusque stultae $K C T \mathbf{7 8 7}$ fractum, debilem] miserum, supplicem $K C T \mathbf{7 9 1}$ cur] quid KCT $\mathbf{7 9 3}$ destinauit] distinauit $K \mathbf{7 9 8 - 8 1 6}$ om. MKC 
Fatis illa uolunt esse canentibus.

805 Nec desunt homines se temerario

Ausu qui simulant flatibus Aetheris

Adflari; et cupidis regibus indicant,

Aeternum tacitus quae Deus occulit.

Hinc multa auspiciis cepta fauentibus,

810 Quae spes uana tulit, mox lacrimabilis

Turpi ludibrio sustulit exitus.

[p. 29]

Subiectas ideo qui moderamini

Gentes imperio, uaticinantibus

Aurem ne facilem pandite creduli,

815 Claro constiterit ni prius Aethere Ipsos teste loqui, quae Deus imperat.

Quin arcete procul qui sibi gratiam

Captant obsequiis, quique bibentibus

Risu blandiloqui pocula condiunt.

820 Vobis ora linunt melle, sed intimos

Correptura sinus toxica porrigunt.

Vestra pace (licet si modo) prodimus,

$O$ reges studiis uera fidelibus.

Illorum uariat uos fauor arbiter,

825 Vt quaeuis agitant flamina populum,

Aut ut sessor equo mollibus annuit

Parenti stimulis, quem iubet ingredi

Nunc pompae similem, nunc Aquilonibus

Qui uerrunt celeres cursibus aerem.

830 Regem sola decet quae colit integram

incorrupta fidem libera ueritas.

Nemo regna sibi credita uindicet

Vt tractet genii sceptra libidine.

Si regnare licet, non licet improbe

835 Aulam flagitiis reddere nobilem.

O Rex o Solymae cur tibi displicet

Vates ille sacer? Vera quod auribus

Iniucunda canit? Debuit aurei

Idcirco solii uiuere particeps,

840 Si pacata duos sceptra capesserent.

$\mathbf{8 1 7}$ Quin arcete] Ablegate $M K C T \mathbf{8 1 8}$ bibentibus] nocentia MKCT $\mathbf{8 1 9}$ Vobis mg. eras. / Risu eras. / blandic $m g$. eras. / Risu s. u. et $m g$. / blandiloqui] et blanditiis $M K C T$ 820-829 om. MKCT $\mathbf{8 2 1}$ eras. pocula ante Toxica $\mathbf{8 3 4}$ improbe] impiis $M K C T \mathbf{8 3 6}$ cur] qua $M K C T \longrightarrow$ 
pretendem eles que faz parte do destino.

Nem falta quem, com temerária ousadia,

finja ser bafejado pela inspiração do céu

e revele aos reis, ávidos de saber,

o que o silêncio de Deus eternamente oculta.

Daí que muitos projectos auspiciosamente iniciados,

movidos por falsas expectativas, terminem em breve,

de forma inglória, mercê de infame ludíbrio.

Por isso vós, que tendes povos

sob o vosso domínio, não acrediteis facilmente

nos que lançam vaticínios

sem antes ficar claro que tal gente,

ao invocar o céu, anuncia os preceitos de Deus.

Mais: guardai distância daqueles que com favores

captam para si simpatias, e dos aduladores

que, com sorrisos, enchem o copo a quem bebe.

Untam-vos a boca com mel, mas por dentro

820

ministram-vos venenos que aprisionarão o vosso coração.

Com a vossa permissão, ó reis, se nos é lícito,

mostramos a verdade com empenho sincero.

Os favores de tal gente, como um juiz, fazem-vos oscilar,

da mesma forma que quaisquer ventos agitam os choupos,

ou um cavaleiro, com leves estímulos,

domina o dócil cavalo, fazendo com que avance,

ora a passo de procissão, ora como os ventos Aquilões

que varrem o céu soprando velozes. ${ }^{35}$

A um rei apenas convém a verdade cultivada

830

de forma isenta e livre, com toda a boa-fé.

Que ninguém se sirva do poder que lhe foi dado

para governar a seu bel-prazer.

Se é lícito reinar, não é lícito entregar à depravação,

de forma indigna, a nobre corte.

Ó rei de Jerusalém, porque te desagrada

o santo profeta? Por te anunciar

verdades incómodas? Deveria ele,

por isso mesmo, viver partilhando o trono real,

se o poder fosse partilhado em paz por duas pessoas.

840

$\longleftarrow \mathbf{8 3 7}$ ille] parte $M K C T /$ quod $s$. u. et $m g$. 837-838 Vera quod auribus - iniucunda canit $o m$. $M K C T \mathbf{8 3 8}$ aurei] aureo $M K C T \mathbf{8 3 9}$ Idcirco solii] In regni solio $M K C T \mathbf{8 4 0}$ duos] duo $M K C T$ $\mathbf{8 4 1}$ aequa] uera $M K C T \mathbf{8 5 0}$ Tot] Iam $M K C T$ 
Odisti monitis aequa salubribus

Hortantem; obsequeris falsa canentibus.

At te poena manet. Nam Deus expedit

Iam casura polis arma tonantibus.

845 O mater scelerum, tu quoque, Ciuitas

Olim sancta, cades. Ludis amoribus

Vanis acta; Deum prodis adultera

Dilectique nouas cornua buculi.

Bello, peste, fame diruta criminum

850 Tot portenta lues. Non sacer horrida

Vates illa ioco uincula concutit. 
Odeias quem, com salutares conselhos, exorta à justiça; vais atrás dos que profetizam falsidades.

Mas espera-te o castigo; Deus já prepara

armas que cairão do céu trovejante.

Ó mãe de crimes, também tu,

outrora cidade santa, cairás. Divertes-te,

seduzida por amores ilusórios; atraiçoas Deus como adúltera

e renovas os cornos do teu dilecto bezerro. ${ }^{36}$

Destruída pela guerra, pela peste e pela fome,

expiarás a monstruosidade de tantos crimes. Não, não brinca

850

o santo profeta ao sacudir as terríveis algemas. 


\section{ACTVS SECVNDVS}

\section{Hieremias. Pver Hieremiae.}

H. Immane Iudae facinus et dirum scelus

Est exaratum ferreo stylo, super

solidi adamantis laminam durissimam.

855 Neque Samuelis Mosis aut magni preces

Cohibere poterunt iure stomachantem Deum.

O dura populi corda uesani, bonis

Ingrata, ueri nescia, ad falsos cito

Cultus deorum prona, cur bellum impium

860 Infertis? hostem scelere cur facitis Deum?

Ardore belli Solyma fatali strepit;

Rex arma caeco corde delusus parat;

Paranda clamant Principes: unus senex,

Quamquam uetantis iussa proponat Dei,

865 Ad sanitatem flectere errantes nequit.

Aliqua cauernis Furia Tartareis tenet

Egressa mentes et, uaporantem facem

Pectoribus adhibens, ad facinus omnes trahit:

Regem, senatum, principes, uulgus. Quid hoc?

870 P. O dura vati sacrosancto tempora!

H. Exclamat ecquis? An puer uenit meus?

P. Vbique fluctus inuenit, casus adit

Vbique uarios. Vndique malorum agmina

In innocentis uatis assurgunt caput.

875 H. Noua quae procella, fare, uentorum tuum

Perflauit animum?

P. Quaero sollicitus patrem.

H. Turbata pauidis ora luminibus geris.

852 Facinus Hebraeae gentis et iniquum scelus KCT $\mathbf{8 5 3}$ ferreo corr. et $m g . \quad \mathbf{8 5 4}$ Solidi adamantis] Adamantis unguem et KCT $\mathbf{8 5 5}$ magni] sancti $K C T \mathbf{8 5 7}$ corda uesani] pectora insani $K C T \mathbf{8 5 9}$ eras. .... ante Cultus C $\mathbf{8 6 1}$ strepit] obstrepit KCT $\mathbf{8 6 2}$ caeco] prono KCT 


\section{ACTO II}

\section{CENA I: JEREMIAS E O MOÇO}

Jeremias - O monstruoso acto de Judá e seu funesto crime ficaram gravados com estilete de ferro sobre lâmina duríssima de sólido diamante. ${ }^{37}$

Nem as preces de Samuel ou do grande Moisés ${ }^{38}$

poderão impedir a justa indignação de Deus.

Ó povo insensato, de coração empedernido, ingrato

a quem faz bem, ignorante da verdade, facilmente atreito

a adoração de falsos deuses, porque provocas uma guerra criminosa? Porque atrais com teus crimes a inimizade de Deus?

Jerusalém agita-se num funesto entusiasmo pela guerra;

o rei iludido, de espírito cego, apronta os exércitos.

Os generais divulgam os necessários preparativos.

Um ancião, embora propondo as ordens contrárias de Deus,

não consegue chamar ao bom senso os transviados.

Uma Fúria qualquer, vinda das profundezas infernais, ${ }^{39}$

ocupa-lhes o espírito e, desencadeando nos corações

paixões loucas, a todos arrasta para o crime:

o rei, o senado, os nobres, o povo. Porquê tudo isto?

Moço - Oh! Como vão difíceis os tempos para o santo profeta!

Jeremias - Quem está a falar? Será que o meu moço está a chegar?

Moço - Por todo o lado ele encontra agitação, por todo o lado

desgraças variadas. De todo o lado grupos de malfeitores

insurgem-se contra a vida do inocente profeta.

JEREMIAS - Que nova tempestade assola com ventos

teu espírito? Fala.

Moço - Procuro-te aflito, meu pai.

JEREMIAS - Denotas preocupação e medo em teu olhar assustado.

$\longleftarrow \mathbf{8 6 4}$ uetantis] Tonantis KCT $\mathbf{8 6 9}$ om. KC $\mathbf{8 7 0}$ O dura uatis tempora, et saeua optimi! KCT $\mathbf{8 7 1}$ ecquis] aliquis $K C T /$ an] num $K C T \mathbf{8 7 4}$ uatis assurgunt] euolant senis caput $K C T$ $\mathbf{8 7 6}$ sollicitus] te meum $K C T \mathbf{8 7 8} \mathrm{Sic}]$ Ita $K C T$ / fatebor] fateor $K$ 
P. Sic est. Fatebor pectoris tristem metum.

H. Audire cupio. Corde sedato explica.

880 P. Postquam dedisti te catenatum foro

Et plebis animos ore turbasti tuo,

Sparsus per urbem rumor exciuit suis

Turbam frementem laribus. Ingenti forum

Plenum corona stabat et uoces tui

885 Repetebat oris. Ecce se uasto gradu

Infert superbus et, loco celso eminens,

Cepit Ananias ore bacchanti loqui.

Quaecumque magni dixeras iussu Dei,

Haec ille miris sustulit clamoribus,

890 Plaudente uulgo. Teque nunc quaerit ferox

Et tumidus ira.

H. Quaerat. Audaces sumus

Ad perferenda probra. Non nouum est mihi

Rabidos ferarum talium dentes pati.

P. En subsequentum turba non longe fremit.

H. Congressus asper restat et bellum mihi.

Ananias. Pver Hieremiae. Hieremias

AN. Vbi ille senior, prodigus uitae suae

Populique nostri pestis, et dirus timor?

P. Audis minantem?

H. Mitte bacchantem, sile.

AN. Quo stultus ore fatur et carmen canit

[p. 32]

900 Fatale? Verba cuius accepit Dei?

P. Peiora medio uomuit insanus foro.

AN. Quosnam timores augur infando inuehit

Et uulgat ausu? Forsan audiuit Deum?

An arte magica potius intexens dolos,

905 Pallentis atros consulit Auerni accolas?

Nam nos futuri consciam mentem satis

Habemus etiam. Nos coruscanti uocat

$\mathrm{Ab}$ arce caeli magnus astrigeri Deus,

$\mathbf{8 8 1}$ ore] uoce $K C T$ / tuo] Dei $K C T \mathbf{8 8 4}$ Plenum corona] Septum caterua $K C T \quad \mathbf{8 9 4} \mathbf{P}$. pers. om. $L /$ subsequentem $K \mathbf{8 9 5}$ asper] igitur $K C T \mathbf{8 9 6}$ senior] uates $K C T \mathbf{8 9 7}$ dirus] 
Moço - É verdade. Confessar-te-ei o grande receio que me invade.

JEREmias - Estou ansioso por te ouvir. Explica-te com calma.

Moço - Depois que te apresentaste algemado no foro

e perturbaste, com tuas palavras, os ânimos da populaça,

espalharam-se pela cidade rumores difusos

que fizeram sair de suas casas pessoas em alvoroço.

O foro estava apinhado de gente e repetia

tuas palavras. Foi então que, com passadas largas,

885

entrou Ananias, ${ }^{40}$ com ar arrogante e, ocupando posição de destaque,

começou a falar, num discurso inflamado.

Tudo quanto disseras por ordem do Deus poderoso,

tudo isso ele rebateu, vibrantemente aclamado

pela populaça. E neste momento procura-te,

890

feroz e inflado de cólera.

JEREmias - Que me procure. Tenho coragem

para enfrentar os ultrajes. Não é a primeira vez

que suporto os dentes raivosos de tais feras.

Eis o bando dos seus seguidores que, pelo ruído, não está longe.

Espera-me um desagradável encontro e a guerra.

895

\section{CENA II: Ananias, Moço E Jeremias ${ }^{41}$}

Ananias - Onde está o ancião que pouco se importa de sua vida e que para o nosso povo é uma peste e um sinistro receio?

Moço - Ouve-lo fazendo ameaças?

JEREmias - Deixa, não ligues a loucos. Silêncio.

ANANias - Que palavras usa esse tonto em seus oráculos funestos?

De que Deus recebe ele mensagens?

900

Moço - Disse coisas piores em pleno foro, com o espírito transtornado.

ANANIAS - Que temores transporta e espalha esse adivinho

com seu abominável atrevimento? Será que escutou Deus

ou, com artimanhas, com recurso a artes mágicas,

faz consultas aos cruéis habitantes do pálido Averno?

$\mathrm{Na}$ verdade, sobre o futuro também nós temos

ideias bem claras. Chama-nos, da sua luzente cidadela,

o Deus poderoso do céu estrelado, e chamou-nos agora

« grauis KCT 900 acceoit] accipit $L \mathbf{9 0 2}$ infando] infausto KCT 903 ausu] ore KCT / Forsan] numquid $K C T \mathbf{9 0 4}$ An (Aut $K$ ) arte magicos infera ferens dolos KCT 905 atros] atrox $L$ 
Et nunc uocauit prospera locutus, nihil

910 Se se minari dixit in plebem suam,

Turbator unus ut frequens clamat senex.

Quem nunc ob oculos quis mihi optanti daret?

H. En me. Volebas ipse praesentem dari?

AN. Quibus e cauernis prodit instantis mali

915 Hic ominator?

H. Vnde tu uates Dei

Age prodiisti?

AN. Spiritu adflatam gero

Mentem superno. Forsan adstrictum tibi

Caeleste Numen mente uecordi putas?

H. Vtinam caleret pectus incensum face

920 Tibi ueritatis, socius in causa fores

Ferresque mecum damna, quae a uobis fero.

AN. Sero sapientem te geres hominem, scio.

Tamen Tonantis dicta memorabo. Cape.

H. Diuina si sunt mente tranquilla audiam.

925 AN. Ego a Tonante missus aeterno loquar, Qui dura casu bella quo mauult regit.

H. Si sunt Tonantis audio.

AN. Carmen nota.

Bis duodena suo cum circumuoluerit astra

Flammifer in curru Titan, ego uasa referri

930 Praecipiam, Babylon quae capto barbara templo

Diripuit, uictorque suam rex duxit in urbem.

Huc etiam captae remeabunt millia gentis, Iussa per Assyrium patriam migrare Tyrannum.

Et cum rege lares captiuo intrare paternos

935 Non sero incipient. Nam dura ergastula fregi, Omnipotens ait, et collo iuga ferrea dempsi.

H. Euentus utinam dicta non fallat tua.

Sed uera Numen faxit ut uerus canas.

Reducat etiam liberum durissima

940 E seruitute patrium regem, sacro

Vetusta templo uasa restituat cito.

Captiua repetant agmina paternos lares.

911 ut - clamat] clamat ut passim KCT 913 Volebas ipse] uolebas quando KCT 917 Forsan] Forsitan $K \mathbf{9 1 9}$ face] tibi $K C T \mathbf{9 2 0}$ Tibi] Face $K C T 921$ quae] quos $L 922$ geres] geris $K$ / hominem] senem KCT $\mathbf{9 2 3}$ Tamen] Tibi sed KCT / Cape] accipe KCT $\mathbf{9 2 4}$ tranquilla] sedata KCT 927 om. KCT 930 capto - templo] templo barbara capto KCT 931 uictorque - 
anunciando-nos acontecimentos auspiciosos.

Não formulou quaisquer ameaças contra seu povo,

como proclama repetidamente apenas este velho agitador.

Quem me dera tê-lo agora à minha frente.

JEREMias - Aqui estou. Não me querias ver na tua presença?

AnANias - De que cavernas acaba de sair este agoureiro

de desgraças iminentes?

Jeremias - Donde saíste tu feito profeta de Deus,

diz-me?

ANANias - Trago minha mente inspirada

pelo sopro divino. Julgas porventura que o poder de Deus

anda associado a essa tua mente insensata?

JEREMIAS - Quem dera teu peito se inflamasse, animado

com a luz da verdade, que fosses meu aliado nesta causa

920

e comigo suportasses os agravos que de vós tenho recebido.

ANANIAS - Comportas-te como alguém que tarda em ser sensato, eu sei; mas referir-te-ei as palavras do Tonante. Escuta.

Jeremias - Se elas vêm de Deus, escutá-las-ei calmamente.

ANANiAs - Falarei como enviado do eterno Tonante

que dá às cruéis guerras o desfecho que lhe apraz

JEREmias - Se são de Deus, escuto.

ANANias - Toma nota do oráculo.

Quando o Titã portador da chama rodear por duas vezes

com seu carro os doze signos, ordenarei que tragam de volta

os vasos ${ }^{42}$ de que a bárbara Babilónia se apoderou ao saquear o templo,

930

e que o rei transportou vitoriosamente para a sua cidade.

Para aqui regressarão também os milhares de cativos

forçados pelo tirano assírio a abandonar sua pátria.

E não tardarão a entrar nos lares paternos, em companhia do rei cativo.

$\mathrm{Na}$ verdade, eu quebrei as duras cadeias, diz o Omnipotente,

e retirei-lhes do pescoço os jugos de ferro.

JEREMIAs - Oxalá a realidade não desmentisse tuas palavras,

mas as confirmasse como verdadeiras o poder de Deus;

sim, que Ele fizesse regressar o rei da nossa pátria,

liberto da terrível servidão, e sem demora restituísse

940

ao templo sagrado seus velhos vasos.

Que a multidão dos cativos regressasse aos lares paternos.

$\longleftarrow$ duxit] uexitque suam rex uictor KCT 935 dura] dira KCT 936 Omnipotens ait] Ait Omnipotens $K \mathbf{9 3 8}$ Sed uera faxit, ut canas, potens Deus $K C T$ 939-942 om. KT 940 E] $m g$. Cx 941 uasa] s.u. $C 1942$ paternos] $m g$. Cx ; patrios $C$ 
Animo parumper collige haec leni tamen:

Tu te Tonantis ore contendis loqui;

945 Carminis eundem testor auctorem mei.

At fonte ab uno, nempe ueridico Deo,

Manare falsum nec simul uerum potest.

AN. Cordata loqueris. Perge. Pro sano mihi

Homine es habendus uera si credis mea,

950 Tua fabulosa.

H. Quantus in uate est pudor!

Repete ante nostrum saeculum uates, prior

Quos uidit aetas. Si recordaris, scies

Cecinisse quosdam laeta, quosdam tempora

Funesta bello, peste, diluuio, fame.

955 Quosdam probauit exitus ueros Dei

Fuisse uates. Dicta quorundam tamen

Figmenta docuit finis. En curru uolat

Cessante numquam Lucifer. Tempus cito

Illud orietur quod tuis dictis fidem,

960 Si nulla narras somnia, aut faciet meis.

AN. O dura ceruix! Rigide flecti non potes?

Quando Tonanti credulum pectus dabis?

H. Quando ipse mentem Dominus adflarit meam

Vatesque uerus uera dictarit mihi.

965 AN. Ex ore loquitur Conditor Olympi meo.

H. Non ille cuius numen et leges colo.

Frustra haec catena non meo in collo riget.

Minatur urbi lugubre excidium, iugum

Seruile regi.

AN. Reprime terrificum, senex,

970 Animi furorem. Spiritum saeuum doma.

Da, da catenam. Refugis? Arripio. Vide

Nolens uolensque quo uoles animo uide.

Ceu frango haec ualido pendentia uincula nexu,

Sic Deus ille potens, flammae iaculator ab alto

975 Dura manu rumpet iuga quae Babylonius olim

Imposuit populis, et colla tyrannide pulsa

Libera barbarica, natalis in arua redibunt

943 Parumper animo collige haec leni precor $K C T \mathbf{9 4 4}$ contendis] contendi $C \mathbf{9 4 5}$ testor] fateor $K C T \mathbf{9 4 6}$ At fonte] Auctore $K C T /$ ueridico] uiridico $L \mathbf{9 4 7}$ Responsa nequeunt accipi contraria KCT 949 credis] credas KCT 951 Repete] Quot KCT 952 Quos uidit] Generauit KCT 953 eras. quod ante quosdam 954 diluuio] diluuiis KCT 956 tamen] exitus KCT 
Mas detém-te um pouco a examinar, serenamente, o seguinte:

tu pretendes falar pela boca do Tonante;

eu sustento ser Ele igualmente o autor do meu oráculo.

Mas duma mesma fonte, precisamente o Deus da verdade,

não pode simultaneamente manar o falso e o verdadeiro.

Ananias - Falas com sensatez. Prossegue. Deverei considerar-te

homem ajuizado se acreditares que minhas palavras

são as verdadeiras e falsas as tuas.

JEREMIAS - Que descaramento o do profeta!

950

Relembra os profetas do tempo passado,

do tempo de nossos pais. Se te recordares, verás:

uns profetizaram tempos risonhos, outros tempos funestos

com guerras, pestes, inundações e fome.

Os factos vieram provar que uns tinham sido

verdadeiros profetas de Deus; mas quanto aos ditos dos outros,

viu-se depois que eram invenções. Repara! Lúcifer ${ }^{43}$ desliza;

o carro nunca pára. Depressa virá o tempo

em que se confirmarão ou as tuas palavras

(se o que narras não são sonhos), ou as minhas.

960

ANANiAs - Ó dura cerviz! Insensível, és incapaz de fazer cedências?

Quando te apresentarás confiante no Tonante?

JEREMIAS - Quando for ele a inspirar minha mente

e, como um verdadeiro profeta, me anunciar a verdade.

ANANias - É pela minha boca que fala o Senhor do Olimpo.

JEREMias - Não Aquele cujo poder e leis eu venero.

Não é em vão que estas cadeias me ferem o pescoço.

A cidade está ameaçada por penosa destruição e o rei

por um jugo servil.

ANANiAs - Domina esse delírio aterrorizador

de tua mente, ó velho; domina esse espírito cruel.

970

Entrega as cadeias, vá. Recuas? Eu agarro-te. Vê!

Contrariado ou não, vê com que disposição de espírito hás-de querer.

Da mesma forma que eu quebro estas cadeias suspensas de vigoroso nó,

igualmente o Deus todo poderoso, que do alto despede o fogo,

romperá com mão forte o pesado jugo que o Babilónio no passado

impôs aos povos e, afastada a bárbara tirania,

os prisioneiros regressarão em liberdade aos campos amados

$\longleftarrow 957$ tandem ante docuit KCT / finis om. KCT 960 faciet] faciat KT 969 terrificum] te mendax $K C T \mathbf{9 7 0}$ Animum furentem et spiritum insanum doma $K C T \mathbf{9 7 1}$ Arripio] abripiam $K$ $\mathbf{9 7 4}$ potens] poli et $K C T \mathbf{9 7 7}$ redibunt] ridebunt $L$ 
Cara soli. Vix stellifero se Lucifer axe

Ardentem per signa feret bis lucida, quando

980 Vndique migrantis uideas examina uulgi

Antiquam patriae dulcis repetentia sedem.

H. Quae non uidebis ipse nec quisquam canis.

AN. O pertinacis pectus insanum uiri!

Impos recede mentis. O fallacium

985 Fraudum tenacem! Spero propiorem Deum

Ac mitiorem. Libera Solymam metu,

Abi exulatum, conde te terrae in sinu.

Ad nota uerto tecta properantem gradum.

\section{Hieremias ET ORACVLVM}

H. Heu quis dolori finis aut poenae modus

990 Mihi afferetur! Pereo, dispereo, tuis

Proficio monitis, Conditor Olympi, nihil.

[p. 35]

Fortasse plebem flectere indocilem meo

Labore possem, regis auersi asperum

Mollire quissem pectus iniecto metu,

995 Si qui iuuare mutua cura senem

Hunc debuissent, arma crudeli impetu

Non intulissent. Ecce mendaci uocor

A uate mendax. Ille caelestem domum

Sibi consulenti praedicat apertam, mihi

1000 Magicos Auerni tribuit obscuri dolos.

Animum calore sentio incendi; aestuo.

Propius Dei timenda maiestas adest.

O. Sacrilega o magnis pro gente exercite curis

Inualidas ultra uires sortemque senectae,

1005 Te Deus omnipotens accersit ab Aetheris aula.

H. En me paratum. Languidum et fractum senem

At tu leuare morte, si iubeas, potes

Diu expetita. Non quod imperiis graue

Parere fuerit magne Dominator tuis,

1010 Sed quia repulsam, missus a caelo, fero.

978 eras. qua ante Lucifer / se s.u. 979 lucida] liuida $L \mathbf{9 8 1}$ Antiquam] Antiquae $C$ Antiquas $K T$ / sedem] sedes $K C$ / eras. terras ante sedes $K \mathbf{9 8 2}$ om. KCT 984 Recede uacue mentis, et mendacibus $K C T$ / fallacium E1; fallacibus E $\mathbf{9 8 5}$ Cumulate penitus fabulis, dabit Deus KCT 986 Promissa nostram libera gentem metu KCT 987 om. KCT 988 uerto] uero $K$ 
de sua terra natal. Bastará o luminoso Lúcifer percorrer duas vezes as pálidas constelações do céu estrelado e de todo o lado verás multidões de gente a regressar, 980 dirigindo-se à sua antiga morada na pátria amada. JEREMIAS - Não verás o que anuncias, nem tu nem qualquer outro. ANANIAS - Ó espírito insensato de pessoa obstinada! Afasta-te, estás fora de ti, sempre habituado a fraudes e artimanhas; eu tenho esperança num Deus mais próximo 985 e mais indulgente. Liberta Jerusalém do medo, afasta-te do país, esconde-te nas entranhas da terra. Dirijo apressadamente meus passos para tectos conhecidos.

\section{CENA III: JEREMIAS E O ORÁCULO ${ }^{44}$}

JeREMIAS - Ai! Onde acabará minha dor? Até onde irá o castigo que me infligirão? Estou perdido! Eu morro! 990 Não recolho fruto algum de teus conselhos, Criador do Olimpo. Talvez pudesse convencer o povo rebelde, com meus esforços; talvez conseguisse amolecer o coração empedernido do rei, incutindo-lhe medo, se os que deviam, com mútuos cuidados, prestar ajuda 995 a este velho não lhe tivessem feito guerra, com atitudes cruéis. Agora o falso profeta apelida-me de mentiroso. Apregoa que a morada celeste abriu-se às suas consultas e a mim atribui-me mágicos embustes do sinistro Averno.

Sinto o meu espírito a inflamar-se; estou em agitação. Aproxima-se, mais e mais, a temível majestade de Deus. Oráculo - Tu que te consomes em cuidados por um povo sacrílego, indo além de tuas débeis forças e da condição da tua velhice, Deus omnipotente chama-te de sua etérea morada.

JEREMIAS - Eis-me às tuas ordens. Mas a um velho doente e alquebrado podes, assim o ordenes, consolá-lo com uma morte há muito ansiada. Não por ser penoso obedecer às tuas ordens, excelso Soberano, mas porque, apesar de enviado pelo céu, sofro a rejeição

$\longleftarrow$ / gradum] gradu $K \mathbf{9 8 9}$ poenae $m g C x$; p.... $C \mathbf{9 9 0}$ Mihi] Vmquam $K C T 994$ Mollire quissem] Lenire possem KCT 995 mutua] sedula KCT 997 intulissent] contulissent $K \mathbf{1 0 0 7}$ At] Quem $K C T \mathbf{1 0 1 0}$ a] e $K C T$ 
In meque populus te ferox ludit Deum.

O. Tu tibi de solido fac uincla rigentia ferro.

Vade age falsidico fer dicta minacia uati.

Vincula materiae fregisti lignea mollis.

1015 Haec Deus infit habet qui ius in bella, secundis

Vt pugnata, malis aut casibus aspera cedant.

Terrarum quaecumque habitant confinia gentes,

Vmbrosos quaecumque tenent animalia lucos

Flectent Assyrio luctantia colla Tyranno.

1020 Namque iugum ferri Dominus ceruicibus addet.

Tuque sacris male conceptis, tu, perfide Vates,

Hoc anno moriere. Scies quid fallere plebem,

Quid sit ab iniussis oracula promere linguis.

H. Discedo. Veniam nuntius cladis tibi,

1025 Insane uates, ore qui fingis tuo

Stellante falso monita de caelo dari.

Ades o meorum prouide laborum comes,

Opera fideli cognite in rebus puer

Periculosis. Rursus in pugnam Deus

1030 Et in catenas supplicem mittit suum.

Affer catenam ferream. Quocum sibi

Certamen esse uoluit imprudens sciet

Ille, ille uates.

P. Non erit iussis mora.

H. Ad te reuertor alme Regnator poli.

1035 Ne quas profundo respue iratus preces.

Sine more fateor ire Solymorum in scelus

Cum rege Proceres. Deuouet poenae caput

Rex sponte, pereat. Vulgus alieno est nocens

Errore miserum. Plebe pro misera rogo.

1040 Tribuenda non est culpa pallanti gregi,

Si continere neglegit pastor gregem.

Quid posco? Regem plebe cum tota impium

Sceleribus operam uideo nauantem. Haud scio

Populone placeat regis exemplo scelus,

1045 An habere regem populus hic talem uelit.

P. Habes catenam pondere immanem, pater.

$\mathbf{1 0 1 5}$ infit] inquit $K C T$ / qui ius] quisuis $K \mathbf{1 0 1 8}$ animalia] animantia $K T \mathbf{1 0 2 0}$ Dominus] durum $K \mathbf{1 0 2 3}$ iniussis] inuisis $K \mathbf{1 0 2 4}$ Discedo. Veniam] Ibo, ibo meritae $K C T$ / cladis tibi] cadis tuae $K \mathbf{1 0 2 5}$ qui] quid $L$ / tuo] tuae $K \mathbf{1 0 2 6}$ Stellante] Stellanti $K T$ / falso] falsa $K C T$ 
e o povo, em fúria comigo, zomba de Ti, que és Deus.

OrÁculo - Faz para ti duras cadeias de ferro maciço.

Vai em frente, fala ao falso profeta em termos ameaçadores:

"Tu quebraste as frágeis cadeias de madeira.

Eis o que proclama o Deus que decide a sorte das guerras

travadas duramente, resultando em vitórias ou derrotas.

Todas as nações que habitam os confins da terra,

todos os animais que povoam os bosques sombrios,

dobrarão seus pescoços rebeldes perante o tirano assírio.

É que o Senhor pôr-lhes-á ao pescoço um jugo de ferro.

1020

E tu, que profanaste os rituais, tu, ó pérfido profeta,

morrerás este ano. Saberás o que é enganar o povo,

o que é proclamar oráculos sem autorização". 45

Jeremias - Afasto-me. Chegarei como mensageiro da tua desgraça, profeta insensato, que pretendes insinuar que da tua boca mentirosa saem oráculos vindos do céu estrelado.

Vem cá, meu rapaz, companheiro fiel de meus trabalhos,

cuja extrema dedicação eu bem conheço

no meio da adversidade. De novo envia Deus

para a luta e para a prisão o seu suplicante.

1030

Traz-me a algema de ferro. Com quem

quis combate ficá-lo-á a saber esse profeta,

esse profeta insensato.

Moço - Farei sem demora o que me pedes.

Jeremias - Volto a Ti, venerável soberano dos céus.

Não rejeites, na tua ira, as minhas preces.

1035

Reconheço que os maiorais de Jerusalém se dão ao crime sem freio, e com eles o rei. Que o rei aceite voluntariamente o castigo.

Que morra. O povo é culpado dum erro alheio.

Pobre dele! Peço pela miserável plebe.

Não se devem atribuir culpas ao rebanho tresmalhado,

se o pastor se desleixa de o manter agrupado.

Que peço eu? Vejo o ímpio rei e com ele toda a plebe

empenhados activamente no crime. Já não sei

se o crime agrada ao povo devido ao exemplo do rei,

ou se é este povo que quer ter um rei destes.

Moço - Meu pai, tens uma algema demasiado pesada.

« $\mathbf{1 0 2 9}$ pugnam] bellum $K C T$ 1030-1046 om. $T \mathbf{1 0 3 1}$ catenam ferream] catenas ferreas $K C$ / Quocum] quorum $K \mathbf{1 0 3 7}$ poenae] poena $K C \quad \mathbf{1 0 3 8}$ Rex - pereat] Meritum paratae $K C \quad \mathbf{1 0 4 5}$ eras. po ante regem 1046 Habes] accipe $K C$ 
Vt fluctus urget in procelloso mari

Fluctum priorem, pluuia ceu caelo cadens

Tellure pluuiam de uaporanti leuat,

1050 Nubesque madida nube de nigra coit,

Ita te labore durus exhausto labor

Et saeua magnas cura post curas premit.

Numquamne dabitur pax senectuti tuae?

H. Sine, puer. Hortor, his querelis abstine.

$1055 \mathrm{Ab}$ orbe nemo condito uitae integer

Scelerisque purus egit immunem grauis

Vitam laboris. Artifex aurum probat

Velut in caminis igne rubefactis, suos

Ita per labores magnus explorat Deus.

1060 Da, da senilem tanta ceruicem premat, Namque illa collum grauior alienum premet.

P. Vtinam secundet quicquid inceptas Deus.

\section{Pver. Hieremias. Ananias}

P. En ante templi limen ille obambulat Vates superbus.

H. Commode fit obuius.

1065 Saluere iubeo prouidum uatem. Doce

An forsan hodie fabulas uanas ago?

AN. Quis me superbe prouocat euntem? Quis es?

H. Responsa uati laeta qui portat bono.

AN. Senex Abramidis noxium nobis genus,

1070 Nondum relinquis urbis offensae lares?

Abi, ominator stragis et belli. Exula.

H. Male proba fundis liuida. Haud seruas modum.

Voca carentem pectore et sensu feram,

At non Abrami noxium populo genus.

1075 Haec te decerent potius et mores tuos,

Qui fraude gentem perdis Isacidum impia.

[p. 38]

Habes corusci iudicem regem Aetheris,

Cui non malo minore quam capite lues.

1054 Hortor] Admoneo KCTE / eras. quel ante querelis $\mathbf{1 0 6 0 - 1 0 6 2 ~ o m . ~} T \mathbf{1 0 6 1}$ Namque] Tamen $K C$ / grauior] grauius KC $\mathbf{1 0 6 3}$ ille obambulat] aerii ambulat KCT $\mathbf{1 0 6 4}$ fit obuius] cerno obuium KCT 1066 Si ante Forsan KCT 1067 Quis me superba uoce pergentem uocat? 
Tal como as ondas no mar revolto empurram

sucessivamente as outras, tal como a chuva vinda do céu

faz levantar mais chuva da terra sob a forma de vapor

e a uma nuvem sombria outra se associa saturada, ${ }^{46}$

1050

assim te oprimem trabalhos penosos, uns após outros,

e grandes cuidados antes de outros mais cruéis.

Nunca mais darão paz à tua velhice?

Jeremias - Deixa-me rapaz. Abstém-te desses queixumes, vá.

Desde que o mundo é mundo, ninguém de vida íntegra,

sem mancha de crime, levou vida isenta de penoso sofrimento.

Da mesma forma que o artífice põe à prova o ouro

em fornos incandescentes, também o Deus Poderoso

experimenta os seus pelo sofrimento. ${ }^{47}$

Sim, sim, que esta pesada algema oprima um velho pescoço.

1060

A verdade é que sobre outro pescoço ela pesará mais.

Moço - Que Deus favoreça tudo quanto empreendes.

\section{CENA IV: Moço, Jeremias e ANanias}

Moço - Ei-lo passeando-se à entrada do templo, o arrogante profeta.

JEREMias - Torna-se fácil a abordagem.

As minhas saudações, sábio profeta. Mostra-me

se eu espalho neste dia histórias sem fundamento?

ANANIAS - Quem provoca arrogantemente os meus passos? Quem és tu?

JEREMIAS - Aquele que traz respostas agradáveis ao bom profeta.

ANANIAS - Ó velho descendente de Abraão que nos és nocivo,

não abandonas ainda os lares da cidade que ofendeste?

Vai-te, agoureiro de destruições e de guerras. Sai do país.

JEREMIAS - Soltas palavras indignas e cheias de inveja; perdes a compostura.

Chama-me animal selvagem, sem coração nem sentimentos,

mas não um descendente de Abraão que envenena o povo.

Isto adequar-se-ia melhor a ti e ao teu carácter,

tu que com sacrílegos embustes deitas a perder o povo de Isaac.

Tens como juiz o rei do céu resplandecente,

por quem serás castigado com a tua vida.

$\longleftarrow$ KCT 1069 Abramidis] hebraeo KCT / nobis] populo KCT $\mathbf{1 0 7 0}$ offensae lares] aerias domos KCT $1071 \mathrm{Abi}$ O KCT 1072 liuida] liuide KCTE $\mathbf{1 0 7 4}$ Abrami] hebraeo KCT 1075 potius] melius KCT 1076 Isacidum] Isaciam KC $\mathbf{1 0 7 8}$ Cui minori (minore K) clade quam uita KCT 
Vaticinio fallace correptum metu

1080 Cur liberasti uulgus et mentem tuis

Fecisti habere credulam mendaciis?

Ergo haec habeto: uiuus haud anno amplius

Caelo frueris. Antequam pulcher suum

Conficiat orbem Lucifer, ciues tui

1085 Feretro locatum te sepulcrali efferent.

AN. Quis credet adeo Caelites in Aethere

Esse otiosos, ut seni narrent meae

Causas futurae mortis, et uitae exitum?

H. Quis credet? Ipse credulam mentem dabis

1090 Pharetrata quando spiculum neruo applicans

Adducta in unum capita mors arcus aget

Telumque mittens ilia alto uulnere

Penetrabit, oculis solis et lucem auferet.

AN. Capiti minaces talia reseruent tuo

1095 Superi; quid horres asperis saetis fera?

Abi una discors Furia Furiarum comes.

H. Iam saeua dicor Furia? Succedunt minae.

Praesentit animus conscius, poenam timet.

AN. Ecquid superba clamitas?

\section{H. Contra impios}

1100 Clamare iubeor.

AN. Cuius imperio?

H. Dei.

AN. Imperia nempe fingere est moris tui.

H. Si te magistrum forte sortitus forem,

Exempla dederas.

AN. Furia, quid agam?

H. Audi Deum.

AN. Hominem molestum fugio. Nam reddi senem

1105 Loquaciorem teneo si rixas alo.

Si dicta dictis arguo, uitae bono

[p. 39]

Securiore laetus ex eo fruar

Quod comminaris. Cetera ut mendax canis

Mihi fabulosum ita exitum denuntias.

1110 H. Infide quando non habes ueris fidem,

$\mathbf{1 0 7 9}$ fallace] fallaci $K \mathbf{1 0 8 1}$ Fecistis $C \mathbf{1 0 8 7}$ meae narrent seni $K C T$ 1088 Causas uel atrae mortis, aut uitae exitum KCT 1091 Coire summa eras. Adducta in unum s.u. / Coire summa eras. Adducta in unum capita etc. $m g$ C1 / Coire summa KT $\mathbf{1 0 9 2}$ mittens] soluens $K C T 1093$ Penetrabit] Penetret KCT / et] hanc KCT 1094 Capiti] Superi $K C T 1095$ Superi] 
Por que razão, recorrendo a falsas profecias,

libertaste o povo do medo que o tolhia

1080

e o fizeste acreditar cegamente nas tuas mentiras?

Fixa então o seguinte: não desfrutarás da vida

além de um ano. Antes que o brilhante Lúcifer

complete seu curso, teus concidadãos levar-te-ão

dentro dum ataúde, a caminho do sepulcro.

1085

ANANias - Quem acreditará que os deuses no céu

estejam tão desocupados que narrem a um velho

as causas de minha morte futura e o fim de minha vida?

JEREMIAS - Quem acreditará? Tu mesmo acreditarás,

quando, munida de aljava, ajustando a flecha à corda,

1090

Morte fizer boa pontaria com seu arco

e, desferindo o dardo, ferir profundamente teus flancos

e privar teus olhos da luz do sol.

ANANIAs - Que os deuses guardem tais ameaças para a tua vida.

Porque te eriças com ásperas cerdas, ó fera?

1095

Afasta-te, companheiro desavindo, Fúria das Fúrias.

JEREMias - Já me chamam Fúria cruel? As ameaças sucedem-se.

A consciência culpada pressente e receia o castigo.

ANANIAS - Porque gritas insolências?

JEREMIAS - Porque me ordenam

clamar contra os ímpios.

ANANias - Quem te ordena?

JEREMIAS - Deus.

1100

ANANias - Inventar tais ordens é hábito teu, não há dúvida.

JEREMIAS - Se por obra do destino tivesses sido meu mestre

ter-me-ias dado exemplos.

ANANias - Que farei, Fúria?

JEREMIAS - Escuta Deus.

ANANiAs - Afasto-me deste homem pernicioso. Estou vendo:

mais palrador se torna o velho se alimento a discussão,

se aos seus oráculos respondo com outros. Desfrutarei,

satisfeito do bem mais seguro da vida,

a partir das tuas ameaças. E sendo falso o que profetizas

também fantasiosa é a morte que me anuncias.

JEREMIAS - Infiel! Já que não acreditas na verdade,

$\longleftarrow$ Capiti KCT 1096 Abi una] Vna una KCT 1104 H. Audi deum eras. C/Hominem] Ego te KCT $\mathbf{1 1 0 6}$ arguo] improbo KCT $\mathbf{1 1 0 8}$ mendax canis] falsum indicas KCT $\mathbf{1 1 0 9}$ Mihi] Ita fabulosum nuntias uitae exitum $K C T$ 
Habere rebus in malis disces tuis.

Non tarda lento poena quae uenit gradu

Errat nocentem. Namque sceleratum rapit

Licet antecedat. Sceleris abscessit pater

1115 Sui pericli monitus, at nihil memor

Vltricis irae, qua Dei numen tumet.

Abibo plenus maximis curis senex,

Quo me uoluntas tulerit, aut quo me dolor

Conceptus urbis clade uentura egerit.

1120 Redibo quando me redire iusserit

Qui de corusca sede despectat solum

Oculisque facta cuncta populorum notat.

Praesaga sentit mens rebellantem Deo

Instare regem. Nempe conuentus aget

1125 Procerumque dictis arma damnosa induet.

Coetum malorum tempus ut uitem monet.

Rex Sedecias. Procervm et Sacerdotvm Ordo. De bello consultatur.

Duces Godolias, Saphatias, Ivcalvs, Phassvrvs, Gedelias.

\section{REX, e solio}

R. Adeste Proceres nobiles regni uiri

Et uos, sacrorum rite conscripti patres.

Regale dubiis munus in rebus iubet

1130 Priuata fugere, tuta conuentu sequi

Consilia patrum publico. Sedilia

[p. 40]

Ex more prisco uestra maiorum damus.

Rex insidebo regio inter uos toro.

IVC. Sacri et profani iuris, ut mos est, patres,

1135 Sedete. Praesens ipse Rex Solymae iubet.

R. Olim tyrannos gentis Isaciae timor

Late occupabat, perque finitimas erat

Respectus oras nominis nostri grauis.

Nunc praeda regi barbaro et atroci sumus;

1140 Pacem coacti singulis annis dato

1113 rapit] capit KCT $\mathbf{1 1 1 5}$ at] et KCT $\mathbf{1 1 1 6}$ Dei - tumet] tumet potens Deus KCT 1120 eras. iusserit ante me / Redibo quando iusserit ab alto arbiter KCT 1127 Sc. non ind. $C$ / eras. patres ante uiri / uiri] mei KCT 1132 En uestra prisco more maiorum (maiore $K$ ) 
aprenderás a acreditar nas tuas desgraças.

Não demorará o castigo que tarda mas não deixará

o culpado sem castigo. A verdade é que ele atinge o criminoso,

ainda que este lhe fuja. Afastou-se o pai do crime,

avisado do perigo, mas de todo esquecido

da ira com que se inflama a majestade divina.

Irei como um velho consumido pelos maiores cuidados,

para onde me levar a vontade ou me impelir a dor

provocada pela desgraça que se abaterá sobre a cidade.

Regressarei quando me mandar regressar

1120

Aquele que da sua luzente morada contempla a terra

e com seu olhar regista tudo o que os povos fazem.

Os presságios do meu espírito avisam-me de que se aproxima

o rei rebelde a Deus. Certamente promoverá reuniões

e, a conselho dos notáveis, envolver-se-á em guerras danosas.

A ocasião recomenda-me que evite este encontro de gente perversa.

CENA V: Rei SEDeCias, Nobreza E Clero deliberam sobre a guerra. Comandantes militares: Godolias, SAfatias, Jucal, Fassuro e Gedelias.

\section{O ReI, do seu trono}

REI - Aproximai-vos, nobres dignatários do reino

e vós, senadores, de acordo com os rituais.

Exige o múnus real, em momentos de crise,

pôr de lado assuntos pessoais e seguir os prudentes conselhos

dos anciãos em assembleia pública. Ocupai os vossos lugares, ordeno-vo-lo, segundo o velho costume dos antepassados.

Estarei no meio de vós como rei, sentado no trono real.

JUCAL - Sentai-vos, como de costume, senadores do direito sagrado e profano. É o rei de Jerusalém quem o ordena.

REI - Outrora, o receio em relação ao povo de Isaac

estava muito presente nos tiranos, e nos territórios vizinhos

profundo era o respeito pelo nosso nome.

Agora, somos presa dum rei bárbaro e cruel,

obrigados cada ano a implorar a paz

1140

« patent $K C T \mathbf{1 1 3 3}$ inter uos] excelsus $K C T$ / toro] loco KCTE $\mathbf{1 1 3 4 - 1 1 3 5 ~ o m . ~ K C T ~}$ $\mathbf{1 1 3 8}$ oras] urbes $K C T$ / nostri] hebraei KCT $\mathbf{1 1 3 9}$ truci ante sumus $K C T$ 
Auro impetrare. Quid queror pacem? Leue est.

Pretio est emenda uita. Spoliati bonis

Vix arma nudi nota tractamus manu.

Nabucdonosor efferus circunsonat

1145 Vrbemque terret, grauior ob nostrum metum.

Si sustinemus regis immanis iugum,

Perpetua nostrum seruitus regnum premet.

Animis et ausu si repellendum, manus

Armate ciues. Vtra sors uobis placet?

1150 GOD. Inuicte Solymae Rector excelsae, manu

Qui sceptra regni clara belligeri tenes,

Te contuere. Quoque te solio Deus

Regem locarit cerne. Regalis domus

Columen haberis. Arcis est instar suis

1155 Validique muri rex, laborantem inclito

Cum celsus animo patriam seruat sibi.

Rex non tyrannus edita regni sedet

Speculator arce, non timet uisam trucis

Belli procellam, non suae quaerit fugae

1160 Latebras opacas, non trucidanda obicit

Hosti efferato terrefactus agmina.

In fronte prima primus audacem gerit

Ducem, uicesque proelii ingenio regit.

Muti ac inulti gentis inimicae iugum

1165 Toleramus adeo leuiter, ut nostri pati

Videamur aliquem sanguinis, non asperam

Immanitatem barbarae tyrannidis.

Nec arma quisquam iusta belligero rapit

Commotus animo? Nunc uelut noctem fugat

1170 Caliginosam stella quae mundo diem

Radiosque adesse nuntiat solis prope,

Ita lux sepultae patriae es natus noua.

Fulgore nubem discute horrentem tuo

Aboleque tandem seruitutis dedecus.

1175 Nitido coruscus ense terrentem doce

Hostem timendam regiae plagam manus

1141 eras. Quaero p ante Quid / queror $C x$; quaero $C$ quaeror $K \mathbf{1 1 4 3}$ nota tractamus] nuda gestamus KCT $\mathbf{1 1 4 7}$ regnum premet] premet genus KCT $\mathbf{1 1 4 8}$ Animis et ausu] Ausu est potente $K C T$ / si] se $K \mathbf{1 1 4 9}$ uobis] magis $K C T \mathbf{1 1 5 2}$ Te contuere] Tete intuere $K C T$ 1154 Columen haberis] Tu columen extas $K C T$ / est] es $L \mathbf{1 1 5 6}$ seruat sibi] cladi eripit $C T$ clade eripit $K \mathbf{1 1 5 8}$ trucis] asperi $K C T \mathbf{1 1 6 1}$ terrefactus] patriae taetrae $K C T \mathbf{1 1 6 2}$ gerit] Ducem KCT 1163 Ducem] Gerit KCT / uicesque] atque casus KCT $\mathbf{1 1 6 4}$ ac] atque $K$ / inulti - inimicae] 
em troca da oferta de ouro. ${ }^{48}$ Porque me queixo da paz? É fácil.

A vida tem de se comprar por um preço. Despojados de riqueza, dificilmente manejamos as conhecidas armas.

Nabucodonosor faz ouvir em redor a sua cólera

e, face ao nosso medo, aterroriza ainda mais a cidade.

Se aceitamos o jugo dum rei cruel,

servidão perpétua pesará sobre o nosso reino.

Se é de repeli-lo com nosso querer e ousadia,

armai-vos, cidadãos. Destas hipóteses qual vos agrada mais?

Godolias - Ó invicto soberano da excelsa Jerusalém

que empunhas os ceptros resplandecentes deste reino aguerrido,

presta atenção a ti: vê em que trono

Deus te colocou como rei. És considerado o sustentáculo

da casa real. Para seus súbditos, o rei é como uma cidadela

e uma forte muralha quando, com nobre coragem,

protege com orgulho a pátria que para ele trabalha.

Edificada a cidadela, é um rei, não um tirano, a sentar-se nela, como vigilante do reino, não receando enfrentar as tempestades da guerra cruel, não buscando subterfúgios pouco claros

para fugir, não expondo, assustado, suas tropas

à ferocidade inimiga, para serem trucidadas.

À frente do exército, é o primeiro a mostrar-se um chefe corajoso

e a controlar com seu talento, o desenrolar dos combates.

Mudos e passivos, toleramos o jugo duma nação estrangeira,

tão resignadamente que parecemos suportar

alguém do nosso sangue, não a cruel

selvajaria duma tirania bárbara.

E não há quem, animado de coragem bélica,

se lance numa guerra justa? Tal como agora afugenta

a noite escura a estrela que anuncia ao mundo

a chegada iminente do dia e dos raios do sol,

também tu nasceste como luz nova para a pátria sepulta.

Dissipa com teu fulgor a nuvem medonha

e acaba de vez com a ignomínia da servidão.

Reluzindo com tua cintilante espada, mostra ao medonho inimigo

que são temíveis os golpes desferidos pela mão do rei

$\longleftarrow$ multi regnis eras. inulti regis s. u. $C$ inulti regis inimici $K C T \mathbf{1 1 6 5}$ leuiter] lauter $K /$ nostri pati] regem dare KCT 1166 Patrium putemus iura non tyrannidis KCT $\mathbf{1 1 6 7}$ Immanitate barbarae hoc regnum premi KCT 1168 quisquam] quiquam $L /$ iusta] ualida $K C T \mathbf{1 1 7 1}$ solis] claros KCT $\mathbf{1 1 7 2}$ natus es patriae noua $C T$ natus es patriae $K /$ noua] om. $K \mathbf{1 1 7 3}$ Discute nigrantem a patria nubem tua KCT $\mathbf{1 1 7 4}$ Et seruitutem (-tis KT) ablue haerentem notam KCT $\mathbf{1 1 7 6}$ eras. uulnus ante plagam 
Hastaeque uulnus esse letiferum tuae.

Age, te uolentem bella magnanimi duces

Sequentur ultro. Qui rebellandi impiger

1180 Auctor fuisti, perge. Telorum satis

Animique nobis robur inuictum scias,

Certis tueri patriam aut tecum mori.

R. Grata elocutum uideo. Sed timeo exitum.

Principia namque laeta non semper ferunt

1185 Extrema laeta.

SAPH. Regia est uirtus nihil

Trepidare, quamuis aspiciat ipsos metus.

R. At ante cladem sapere prudentis scio.

SAPH. O peruetustae magne frenator domus,

Quem clara Solymae moenia appellant ducem;

1190 Quem mixta uulgo tota nobilitas patrem.

Tantum tueri nomen audendo potes.

R. Etiam perire leuiter audendo potest.

GED. Sceptrum nisi hostis e manu atroci rapis,

Regnas tyranno barbaro, haud regnas tibi.

1195 Exue timorem, quodque concedit Deus

Capesse fortis regiae sortis decus.

R. Idem minatur ergo cur cladem Deus?

SAPH. Quis est minarum nuntius?

R. Vates meum

Qui turbat animum.

GOD. Parce sunt fatui minae.

1200 R. Sed nempe fatuum metuo, si iussu Dei Praesagit urbi flebile exitium meae.

SAPH. Meliora Numen agitat.

GOD. Exclude hunc metum.

R. Simulare uultu spem mihi est facillimum,

At palpitante pectore timorem premam,

1205 Adigente mentem saepe conscientia.

PH. Adeone uatis dicta lymphati times?

GOD. Ego puniendum, non timendum dicerem.

R. Existimassem pariter insanum senem,

Occulta sed uis impedit. Nec sat scio

1177 uulnus] morsus $K C T$ / letiferum] trepidandos $K C T \mathbf{1 1 7 8}$ Age] En $K C T$ / magnanimi] delecti KCT 1179 Sequentur ultro] Sequimur ouantes, KCT / Qui] ut KCT 1180 perge] sic age $K C T$ / telorum] armorum KCT $\mathbf{1 1 8 4}$ namque] quoniam KCT $\mathbf{1 1 8 6}$ aspiciat - metus] unde quod timeat sciat $K C T \mathbf{1 1 8 7}$ At] Et $C T$ En $K \mathbf{1 1 8 8}$ G. pers. $K$ / magne] magnae $L$ $\mathbf{1 1 9 1}$ potes] potest $K \mathbf{1 1 9 3}$ hostis - rapis] hosti demis audaci manu KCT $\mathbf{1 1 9 6}$ Fortis capesse 
e mortais as feridas abertas pela tua lança.

Em frente. Se quiseres a guerra, os magnânimos generais

seguir-te-ão voluntariamente. Diligente autor da sublevação,

vai em frente. Avança. Conhece a força invencível

1180

das armas e da coragem que há em nós,

prontos a defender a pátria ou a morrer contigo.

REI - Agradaram-me essas palavras, mas temo pelo resultado.

A verdade é que nem sempre começos auspiciosos

conduzem a um feliz.

1185

SAFATias - É virtude régia

não revelar fraqueza, mesmo consciente dos próprios receios.

REI - Eu sei, mas quem é prudente usa de sensatez face à desgraça.

SAFATIAs - Ó chefe de tão vetusta e grandiosa casa,

a quem as ilustres muralhas de Jerusalém chamam seu comandante,

a quem toda a nobreza e o povo chamam pai,

1190

apenas com tua ousadia podes defender o teu nome.

REI - Também se pode morrer sendo-se levianamente ousado.

GEDELIAS - Se não arrebatares o ceptro das mãos cruéis do inimigo,

reinas para o bárbaro tirano, não para ti.

Sacode o temor e, com coragem, procura alcançar

1195

o esplendor da condição régia que Deus te concede.

REI - Porque me ameaça então o mesmo Deus com a destruição?

SAFATIAS - Quem agita tais ameaças?

REI - O profeta,

que me perturba o espírito.

Godolias - Não ligues a ameaças de idiotas.

REI - Mas eu receio um idiota se for por ordem de Deus

1200

que ele pressagia um fim funesto para a minha cidade.

SAFATIAS - A divindade pensa em coisas melhores.

Godolias - Põe de lado esse temor.

REI - É-me facílimo simular esperança no rosto,

mas hei-de abafar o temor, o sobressalto de meu coração

e a consciência a constranger-me tantas vezes o espírito?

FAssuro - Receias assim tanto os oráculos desse profeta delirante?

Godolias - Eu diria que em vez de o temerem, deveriam puni-lo.

REI - Também eu julgaria o velho um insensato,

mas impede-mo força oculta. Nem eu sei bem

« KCT 1197 ergo - cladem] arce de summa KCT 1199 fatui] fatuae $K \mathbf{1 2 0 0}$ nempe] om. $K$ $\mathbf{1 2 0 1}$ exitium] excidium $K C T \mathbf{1 2 0 2}$ agitat] statuit $K C T \mathbf{1 2 0 3}$ om. KCT $\mathbf{1 2 0 4}$ Negabo fateor ore, sed animo dabo, KCT 1206 SAPH. pers. KCT 1207 Punire leges non timere illum iubent KCT 1208 Existimassem] Putare uellem KCT 
1210 Quid me retardet.

SAPH. Libere dicam: timor.

PH. Tibi si timorem dira religio incutit, Ostenta laeuum si qua portendunt Deum,

Per hos require legis augustae patres,

Sacri et profani conscios. Tardum ob senem

1215 Trepidare, regi non leuis tanto est nota.

Ignotus et plebeius, obscuri oppidi

Colonus, urbem nuper ab aratro inclitam

Ingressus, istas publice turbas dabit?

R. Si pacis almae tempora ac belli horridi

1220 Momenta nostri penitus arbitrii forent,

Neque superorum de uoluntate anxius

Penderet animus, facile consilio regi

Pax blanda nostro posset aut bellum capi.

Verum superna rebus humanis praeest

1225 Caeli potestas. Res agit mortalium

Aliquando laeuus, dexter aliquando Deus.

Infirma saepe robore tuetur suo,

Vasto et ruinae concutit firma impetu.

Nisi durus esse laeuus ac asper uelit,

1230 Prouisa belli commode est ratio mihi.

Vos ergo, patres, quos Sacerdotum grauis

Commendat ordo, dicite ex adytis refert

Si quid secundum summa maiestas Dei.

V. Dum rex ab alto culmine inuictus ducum

1235 Verba audiebat, integra quorum fide

Tractantur arma, deditos sacris uiros

Silere merito cognitus fecit pudor.

At nunc rogatus fabor et quicquid tua

Ex dignitate duxero ingenue loquar.

1240 Non ut fauoris aulici assidui aucupes,

Qui blandiendo gratiam captant sibi.

Depone uates moneo degenerem metum.

Agnosco superos. Nuper ardentem poli

Regione clari currere aspexi facem.

1245 Interque nimbum lucis effusae aureum,

1210 ut ante dicam KCT 1211 G. pers. K God. Pers. T 1214 ob] om. KCT 1223 capi] instrui KCT 1225 Caelo potestas, de coruscanti imminet KCT 1228-1227 transp. KCT 1228 et] om. KCT 1229 Ni laeuus esse durus, $K C T$ / ac] atque $K \mathbf{1 2 3 5}$ Verba audiebat] Verbis 
o que me inibe.

SAFATIAS - Dir-to-ei, sem rodeios: é o temor.

FAssuro - Se é um profundo escrúpulo que te faz recear, se alguns presságios prognosticam um Deus desfavorável, informa-te junto destes anciãos da lei venerável, peritos do sagrado e do profano. Assustar-se com um débil velho num rei tão poderoso não é coisa sem importância

Um desconhecido e vulgar habitante dum humilde lugarejo,

Acabado de chegar a uma ilustre cidade, vindo do campo, ${ }^{49}$

há-de provocar tais desordens em público?

REI - Se os tempos da reconfortante paz e os momentos da horrível guerra se encontrassem sob o nosso arbítrio,

e o nosso espírito não dependesse ansiosamente

da vontade dos deuses, bem poderia o rei,

na nossa assembleia, optar pela doce paz ou pela guerra.

Mas quem preside aos negócios humanos

é o supremo poder do Céu. Deus os conduz,

umas vezes de forma adversa, outras vezes de feição.

Protege muitas vezes com sua força o que é frágil

e sacode com violência até à ruína o que é sólido.

A não ser que Ele queira ser duro, desfavorável e cruel,

a razão de ser da guerra é bem encarada por mim.

Portanto, senadores, a quem a respeitável classe sacerdotal

recomenda, dizei se, de seus santuários,

a suprema majestade de Deus refere algo de favorável.

Profeta - Enquanto o invicto rei, de seu elevado trono,

escutava as palavras dos generais que, com total fidelidade,

comandam seus exércitos, o habitual respeito fez, com razão,

que se mantivessem calados os que se ocupam dos sagrados rituais.

Mas agora, a teu pedido, falarei e direi

com franqueza, tudo o que a tua dignidade me sugerir.

Não como os áugures da corte, sempre à espreita de favores,

que com lisonjas tentam atrair simpatias.

Recomendo-te, como profeta, que abandones esse medo ignóbil.

Eu conheço os deuses celestes. Contemplei há pouco

o astro flamejante, cumprindo seu trajecto pelo céu cristalino.

E no meio duma nuvem dourada espargindo luz,

« uacabat $K C T \mathbf{1 2 3 6}$ deditos] debitos $L \mathbf{1 2 3 7}$ pudor] timor $K \mathbf{1 2 4 1}$ blandiendo] mentiendo KCT $\mathbf{1 2 4 2}$..... eras. et uates $s . u$. C $\mathbf{1 2 4 3}$ poli] facem $K C T \mathbf{1 2 4 4}$ Regione puri crepere conspexi aetheris KCT $\mathbf{1 2 4 5}$ aureum] igneum KCT 
Vox haec per auras tonuit et uasto sono

Vtramque nitidi solis impleuit domum,

Et quae cadentem quaeque nascentem uidet.

R. Superi secundent uisa. Quid tandem? Refer.

[p. 44]

V. Fauete linguis carmen auditum cano.

\section{VATICINIVM FALSVM}

Huc sacra, inquit, o Sacerdos infula splendens ueni.

Lugubrem fugabis unus ore tristitiam meo.

Nam tibi en iucunda plebi nuntia ferenda affero.

Ibis ad superba Solymae tecta dilectae. Deus,

1255 Inquies, statuit quietem mitior tutam dare.

Non nouos belli tumultus ferrei aut cladem nouam

Horrida molitur ira feruidus. Franget iugum

Barbarae Babylonis. Exul natio in proprios lares

Patriae redibit. Ite, frugiferos agros

1260 Falcibus demetite. Quisque faenore exultet suo

Accubet uirente sub fico et nouam uitem premat.

SAPH. O certa uatis optimi praesagia,

Felicitatis nuntium optatae! Excita

Regale pectus. Scande laxatis equum

1265 Frenis uolantem, casside rubentem nitens

Vomente flammam profer in lucem caput.

$\mathrm{Ab}$ arce belli rauca det signum tuba

Classicaque resonent, concute tuorum tua

Virtute mentes: ridet e caelo tibi

1270 Victoria. Albis illa iam pennis uolans

Bellare contra barbaros hostes iubet.

R. Humana bello nobili ut pugnem monent.

Diuina laetum proferunt oracula.

Arma meliore nemo consilio induit.

1275 PH. Aethere fauentem uideo tranquillo Deum.

Natale ualidum militem praebet solum.

Vicina lectis millibus tellus iuuat.

His si timemus copiis, nostris iugum

[p. 45]

1246 Haec uox K 1249 Superi secundent, omen auditum refer KCT 1250 carmen - cano] omen effabor Dei $C T$ omen effabor $K \mathbf{1 2 5 3}$ en] om. KCT 1255 eras. tumultus ante belli 1261 Accubet] Accumbet $K$ / premat] premet $K 1263$ nuntium] nuntia $K C 1265$ rubentem] 
ouviu-se nos céus esta voz que, com seu poderoso som, alcançou as duas moradas do sol brilhante, a que o vê no seu ocaso e a que o vê nascer com a Aurora. ${ }^{50}$

REI - Que os deuses favoreçam tais visões. Mas diz o que tens a dizer.

Profeta - Fazei silêncio. Vou proclamar o oráculo que escutei.

1250

\section{FALSO OrÁCUlo}

Aproxima-te, sacerdote, que resplandeces com a sagrada ínfula.

Só tu, com minhas palavras, afugentarás a lúgubre tristeza.

Trago de facto notícias agradáveis para anunciares ao povo.

Irás até às soberbas moradias da amada Jerusalém e dirás:

Deus, em sua indulgência, decidiu conceder-nos uma paz tranquila.

1255

Novos tumultos de guerras cruéis, ou novas desgraças

Ele não prepara, ardendo em sombria cólera. Quebrará o jugo

da bárbara Babilónia. A nação exilada regressará

aos lares de sua pátria. Ide. Aos campos carregados de frutos

lançai as foices; alegre-se cada um com seus lucros;

1260

deite-se à sombra da figueira verdejante e esprema o mosto novo. ${ }^{51}$

SAFATIAs - Ó oráculos verdadeiros dum excelente profeta,

anúncio da ansiada felicidade! Anima-te,

coração real. Monta num cavalo galopando

à rédea solta, um elmo de vermelho vivo como chama

reluza em tua cabeça à luz do dia.

Do alto da cidadela a rouca trombeta dê o toque de guerra,

e os clarins ressoem: sacode a mente de teus homens

com tua coragem. Vitória sorri-te do céu.

Ei-la já voando com suas asas brancas,

ordenando que combatas os bárbaros inimigos.

REI - Os oráculos dos homens exortam-me ao combate em guerra

nobre; os divinos falam-me em tom optimista.

Ninguém dota a guerra de melhor conselho.

FAssuro - Vejo Deus tranquilo no céu, apoiando-te.

O solo pátrio fornece-te robustos soldados.

As regiões vizinhas auxiliam-te com sua tropa de elite.

Se com tais efectivos temos receio, somos nós a colocar

« rubenti $K T \mathbf{1 2 7 1}$ barbaros hostes] barbaram gentem $K C T$ / iubet] iube $K \mathbf{1 2 7 3}$ Diuina finem oracla felicem canunt KCT $\mathbf{1 2 7 5}$ pers. om. KCT / tranquillo] de celso KCT tranquillum $L$ 
Graue seruitutis ponimus ceruicibus;

1280 Non insolente ponit Assyrius manu.

R. Animo repositum penitus intrepido sedet

Pugnare; uota fida sociorum sequar.

GOD. Nunc regna terrae parta fecundae tibi

Rex esse fateor; nunc tuo aptari potest

1285 Diadema iuste uertici, et sceptro manus

Clara decorari, quando non precario

Velut ante regnas, iure sed regnas tuo.

En miles arma corporis custos quatit;

En tela crispat; ore iam truci fremit.

1290 EX. Arma, arma, dentur arma. Babylonem graues

Sentire fas est ignis et ferri uices.

R. Maiore flamma rapior in bellum, alacri

Voce ut duellum poscere aspicio meos.

\section{Tribvnvs Militvm (ad regem)}

Fer citus arma, tuas emitte in proelia turmas

1295 Rex Solymae generose, cadant quicumque micantem

Te contra gladium nudarint. Signaque laeto

Auspicio mediis regni penetralibus effer.

Si bellare paras, stricto si hostilia ferro

Moenia concutere et campos exurere flammis,

1300 Incipe terribilem lituis accendere Martem

Isaciamque tubis in proelia mittere gentem.

Inclita si patriae defendere limina curas

Et rabidum nostris arcere penatibus hostem,

Turrigeras facile est murorum scandere pinnas

1305 Ac hostem iaculis in castra repellere uictum.

Iusseris at quotiens in pugnam exire, ruentes

Ibimus, audendo uolucri super ardua saltu

Castra, necem manibus ferroque ignique feremus.

Et spoliata dabunt raptam tentoria praedam.

1310 Effundat Babylon campis se diues apertis,

Arma armis cumulet: non ipsi auertere talem

1280 insolente] insolenti $K C T \mathbf{1 2 8 5}$ iuste] merito $K C T \mathbf{1 2 8 8}$ miles] mitis $K \mathbf{1 2 9 1}$ eras. cladis et belli ante ignis / ignis et ferri] cladis et belli KCT $\mathbf{1 2 9 3}$ Voce - duellum] Cum uoce bellum KCT 1294 proelia turmas] bella cohortes KCT 1295 cadant] cadat $L \mathbf{1 2 9 6}$ nudarint] nudarit $L \mathbf{1 2 9 8}$ si stricto $K C T$ / hostilia] astilia $K \mathbf{1 3 0 1}$ Isacidamque $K$ / tubis] tuis $K C$ 
sobre nosso pescoço o pesado jugo da servidão, não o Assírio, com suas mãos insolentes.

REI - Estou inteiramente decidido a combater com denodo;

darei seguimento aos desejos sinceros de meus aliados.

Godolias - Os reinos da terra fecunda foram criados para ti, agora o reconheço, ó rei; agora é possível, merecidamente, ajustar-se à tua cabeça o diadema e enfeitarem-se com o ceptro

tuas mãos ilustres, pois reinas, não a título precário

como antes, mas de pleno direito.

Vede, a sentinela agita as armas do seu corpo;

brande os dardos; já saem rugidos de sua boca feroz.

Exército - Armas! Armas! Dêem-nos armas. É justo que Babilónia

1290

sinta a dura provação do fogo e das armas.

REI - Sinto-me arrebatado por um entusiasmo maior

ao ver meus súbditos apelar ao combate com voz ardorosa.

\section{CENA VI: TRIBUNO DA MILÍCIA (dirigindo-se ao Rei)}

Pega rapidamente em armas, ${ }^{52}$ envia teus esquadrões a combater, nobre rei de Jerusalém. Morram todos os que contra ti desembainharem a reluzente espada. Os estandartes do reino retira-os do interior do santuário, com bom augúrio.

Se te dispões a combater, se, de espada em punho, pensas aterrorizar, as muralhas inimigas e reduzir a cinzas seus campos, começa por despertar o terrível ardor guerreiro ao som dos clarins 1300 e enviar para o combate ao som de trombetas a nação dos filhos de Isaac. Se te preocupas em defender os ilustres palácios de tua pátria e em manter longe de nossas casas o furioso inimigo, é fácil escalar as torres das muralhas providas de ameias e, com dardos, empurrar para os seus arraiais o inimigo vencido.

Mas sempre que ordenares que se avance para a luta, avançaremos de rompante e com ousadia sobre os fortes acampamentos.

Em acção repentina, levaremos a morte, pela espada e pelo fogo, e as tendas despojadas darão azo a abundante pilhagem.

Apresente-se em campo aberto a rica Babilónia, com exércitos e mais exércitos: os Assírios não conseguirão,

— 1302 limina] pergama KCT 1305 repellere] remittere KCT 1306 Iusseris et quotiens foribus pugnare reclusis KCT $\mathbf{1 3 0 8}$ Hostis castra, necem ferro, clademque feremus $C$ Elati monimenta necem, clademque feremus $K T \mathbf{1 3 0 9}$ raptas tentoria praedas $K C T \mathbf{1 3 1 0}$ campis] portis $K C T$ 1311 auertere] excindere $K C T$ 
Assyrii, aut bello poterunt mollire iuuentam.

Infremite, et magnis deposcite uocibus hostem.

EX. In Babylona tui bellum te poscimus omnes.

1315 SAPH. Age militaris tympani ad uastum sonum

Praebete lustrum bellicum, rauco strepant

Inflata cantu cornua et lituis canor

Permixtus aures feriat horrificae tubae.

R. Duces, praeite. Hic agmen extremus sequar.

1320 Praeibo in acie. Videat armatum meus

Me miles. Ite, regiis tectis date

Suspensa nobis arma.

GOD. Belligeris meum est

Aptare membris arma Regis incliti.

SAPH. Deferre nostrum. Magne regnator, uide.

1325 His tectus hostem uince truculentum, tuis

Post bella figes postibus, quae nobili

Splendida trophaeo praedicent uictoriam.

R. Pondera micantis solida thoracis meis

Aptentur umeris. Ocreae suras tegant.

1330 Ornata cristis galea Puniceis caput

Sed aperta, miles cernat ut uultum, premat.

Ensis sinistrum muniat fulgens latus.

Hastam polita fraxino ingentem date.

O hasta iactum bracchii numquam mei

1335 Frustrata, totiens sanguine rubente efferis

Madefacta pugnis, media nunc regis manu

Comprensa quateris. Martis in dubium ruo

Discrimen atri. Pugna cum toto arserit

Violenta campo, dira cum ferri seges

1340 Volitarit aura mobili, si congredi

Fortuna dederit rege cum Babylonio,

Contorta nisu prospero et cursu uola.

Letale uulnus affer in praecordia

Illapsa. Auernum uisere tyrannum iube.

1345 EX. Age rex auorum similis.

PH. O clarum indole

Proaui Dauidis! Ille ceu funda caput

1316 strepant] crepent KCT 1317 Inflata] Pulsata $K C T$ / cornua] classica KCT / eras. castra ante classica $K \mathbf{1 3 1 9}$ Properate uos, hic agmine extremo sequar $K C T \mathbf{1 3 2 1}$ teicts $L$ 1324 Magne Reganator] Summe rector KCT 1325 tuis] arduis KCT 1330 puniceis] purpureis 
em combate, repelir ou levar de vencida uma juventude como esta.

Gritem ameaças; desafiem o inimigo a altas vozes.

ExÉrcito - Todos nós, teus súbditos, queremos guerra contra Babilónia.

SAFATIAS - Vamos, ao som cavo do tambor de guerra

anunciai o recenseamento militar; ressoem ruidosamente

as cornetas e que o som da terrível trombeta,

misturado ao dos clarins, fira os ouvidos.

REI - Generais, ide à frente. Eu irei na retaguarda do exército.

Em combate, tomarei a dianteira. Que meus soldados

me vejam armado. Vá. Trazei-me as armas que estão dependuradas

nos aposentos reais.

Godolias - Compete-me a mim ajustar

as armas aos ombros guerreiros do nobre rei.

- E a nós ir buscá-las. Excelso soberano, repara:

revestido com elas, vence o feroz inimigo.

Após o combate, afixá-las-ás às portas de teu palácio

para que, anunciem reluzentes a vitória, como um glorioso troféu.

REI - Ponham-me sobre os ombros o peso compacto

da brilhante couraça; protejam-me as pernas com as grevas;

que o elmo, engalanado com penachos cor de púrpura,

mas aberto, para que os soldados me vejam, me cubra a cabeça;

que a espada cintilante me proteja o flanco esquerdo;

passai-me uma lança comprida, feita de freixo polido.

Ó lança, que nunca frustraste o arremesso do meu braço,

que tantas vezes te tingiste de sangue escarlate,

em cruéis combates; segurando-te pelo meio, brande-te agora

a mão do rei. Precipito-me para onde o combate se trava

de forma mais renhida. Quando a violência da refrega incendiar

todo o campo de batalha, quando a ceifa cruel da espada

esvoaçar na leve brisa, se a fortuna me proporcionar

o encontro com o rei da Babilónia, voa,

arremessada com impulso e direcção certa.

Abre ferida mortal nas entranhas que trespassares.

Obriga o tirano a visitar o Averno. ${ }^{53}$

ExÉRcito - Em frente, ó rei igual a teus avós.

FASSURo - Imagem notável de teu avô David.

Tal como ele, atingindo-lhe a cabeça com a funda, ${ }^{54}$

$\longleftarrow$ KCT 1331 Sed aperta fortem militem ut cernam, premat KCT / fortem s. u. C 1333 e polita $K C T 1335$ rubente] rubenti $K C T \mathbf{1 3 4 0}$ aura] arua $K C \mathbf{1 3 4 4}$ Dillapsa uisere protinus Auernum iube $K C \mathbf{1 3 4 5}$ PH. pers. om. KCT / O clarum] et magni $K C T \mathbf{1 3 4 6}$ Proaui] Genite $K C T$ 
Diuerberante strauit immanem feram,

Visu tremendum corpore gigantem, arduis

Excelsiorem nubibus, regem trucem

1350 Ita iugulatum dextera sternes tua.

R. Coniecta sors est. Pace neglecta furit

Ardor duelli. Bella qui poscit gerat

Animo superbo. Spiritus sume inclitus

O rex auitos. Sed quis intrepidum timor

1355 Pepulit repente? Forsan incepti piget?

Reuocare turpe est. Flectat in portu ratem

Qui rostra cano prima monstrauit mari.

Vento reflante nauta non undas arat.

At rex secundis uadit ut uentis, fretum

1360 Animosus idem per procellosum ruit.

Non arma ponit capta regnator semel.

Cessare tantum uictor aut uictus solet.

[p. 48]

\section{Hieremias. SEDEcias}

H. Praeclara ratio! Talia quis hominum probet

Aut improbare certet? Errasti semel,

1365 Reuocare gressum pudeat? O furor, furor

Vecordis animi. Non fuit sceptro diu

Natus gerendo, cuius hanc sententiam

Cerebrum tuetur. Est tibi erratum semel;

Redire retro pigeat?

R. An uoces tuas

1370 Totiens repulsas audiam? Arcete hunc procul.

H. Vtinam parumper oris audisses mei

O Rex, querelas. Despicis amantem tui

Et dicta apertis uana falsorum auribus

Admittis hominum.

R. Falsa me quorum arguis

1375 Audire dicta?

H. Mille se coram Deum

Nouisse iactant, quos Deus numquam suo

1349 trucem] ferum KCT 1350 sterne dextera $K \mathbf{1 3 5 2}$ Ardor] Amor KCT 1353 inclitos KCT $\mathbf{1 3 5 4}$ auitos] Sedecia KC/Sedecc.. eras. et Sedecia s. u. Cx $\mathbf{1 3 5 5}$ Forsan] Numquid $K C T 1356$ Flectat] flectere $K C T$ / in] om. KC 1357 Qui] Quae $K C T$ 1358-1360 Testantur omnes esse naucleri probrum substit. KCT 1361 Non] Et KCT / ponit] ponet KCT / semel.] 
lançou por terra a monstruosa fera, um corpulento gigante de aspecto impressionante, mais alto que as altas nuvens, também tu derrubarás o rei feroz, degolado pela tua dextra.

REI - As sortes estão lançadas. ${ }^{55}$ Posta de lado a ideia da paz, domina-me a paixão da guerra. Quem reclama a guerra

que a dirija com orgulho. Assume os sentimentos de teus antepassados, ilustre rei. Mas que receio repentino abalou a tua intrepidez? Retrais-te perante o que iniciaste?

É vergonhoso recuar. Que volte o barco no porto quem mostrou ao mar argênteo os primeiros esporões dos navios.

Com ventos contrários o marinheiro não navega.

Mas um rei, tal como avança sob ventos favoráveis, lança-se igualmente com coragem por mares agitados. 1360 Um chefe não depõe uma só vez as armas que empunha; tem por hábito deter-se apenas como vencedor ou vencido.

\section{CENA VII: JeREmias e SEDecias}

JEREMIAS - Brilhante raciocínio! Quem aprovará tais coisas?

Quem se esforçará por reprová-las? Erraste uma vez; envergonhas-te de voltar atrás? Ó louca cegueira, a dum espírito insensato! Não nasceu para reinar muito tempo aquele cujo espírito alimenta esta maneira de ver. Erraste uma vez; custar-te-á voltar atrás? REI - Hei-de escutar tantas vezes tuas odiosas palavras? Afastai-o para longe daqui.

JEREMIAs - Oxalá tivesses escutado por momentos, ó rei, os queixumes de minha boca. Desprezas quem te quer bem e dás ouvidos a palavras enganadoras de homens mentirosos.

REI - Acusas-me de ouvir palavras enganadoras de quem? 1375

JEREmias - Gabam-se perante ti de conhecer Deus muitos a quem Deus nunca julgou

« semel? KCT 1362 om. 1363 probet] neget KCT 1366 Vecordis] Excordis CT / fuit] om. K 1367 post hanc] cerebrum probat KCT 1368 Sententiam; peccare si semel obtigit KCT $\mathbf{1 3 7 0}$ audiam] audio K $\mathbf{1 3 7 2}$ eras. Surdus ante Despicis / post querelas] Surdus es famulo tuo KCT $\mathbf{1 3 7 4}$ arguis] increpas KCT $\mathbf{1 3 7 5}$ coram] uates KCT 
Dignatus ore est. Turbidi, ingenio feri,

Narrare proni fabulas, oracula

Diuina fingunt. Supplicem, o audi tuum

1380 Me me loquentem patrii imperio Dei.

R. Iam dicta dices.

H. Fateor. Aegroto placet

Praebere rursus pharmacum, quamquam semel

Fastidiosa non recepit cruditas.

R. Figmenta capitis lubrici non audio.

1385 H. Solymae cremandae sceptrifer gressum tene

Magnumque tandem disce reuereri Deum.

Sine uoce sensus penetrat ac audit pios

Et ubique facta cernit. At quamquam malos

Tardus sequatur ultor, ultricem suo

1390 Effundet iram tempore. Auerso gradum

Vultu reflectis? Firma stat sententia.

Inimica ueri Solyma cum toto cadet

Ambusta populo. Tuque natorum uidens

Truncata capita, caecus, et mortem expetens

1395 Captiua subdes colla barbarico iugo.

R. Quid me alta cogis rumpere o fallax mali

Saepe ominator exitus silentia

Vulnusque totiens ore conceptum tuo

Nudare uerbis? Tune regali obstrepes

1400 Decori molestus? Sacra maiestas tibi

Non est timori? Non times regis caput,

Olei quod unxit purus infusi liquor?

Quas deinde iactas nenias? Tecum Deus

Consilia solo miscet et sancta alterum

1405 In urbe uatem nescit? Hanc laudem tibi

Cur occupabis solus? Age, alios ubi

Relinquis aut quo tot patres ponis loco?

H. Consiste Solymae Rector o miserae parum,

Vno querelas tollo dum uerbo tuas.

1410 Honore non te regio sperno inclitum.

Tua colenti est sacra maiestas mihi.

Sed cum Tonanti seruiam atque illum colam,

1377 Dignatus - est] Adflauit igne $K C T$ / turbido $K \mathbf{1 3 8 0}$ Me me] Certo $K C T$ 1381-1395 om. T 1383 Fastidiosa cruditas egit foras KC $\mathbf{1 3 8 4}$ om. KC $\mathbf{1 3 8 6}$ Summumque melius disce uereri $K C \mathbf{1 3 8 8}$ malos] impios $K C \mathbf{1 3 9 0}$ Auersum gradu $K \mathbf{1 3 9 1}$ Vultum KE 1392 toto] tota $L 1398$ Vulnusque] Verbisque KCT 1399 uerbis] uulnus KCT 1400 Decori molestus] Insane 
dignos de sua palavra: violentos, de mau carácter,

dados à narração de fábulas, forjam oráculos divinos.

Mas ouve o teu suplicante, ouve-me a mim.

Falo-te por ordem do Deus dos nossos pais.

1380

REI - Já dirás as tuas profecias.

Jeremias - Agrada-me, confesso, apresentar

de novo o remédio ao doente, embora da primeira vez

uma fastidiosa indigestão o tenha recusado.

REI - Não ligo a invenções de mentes delirantes.

JEREMIAS - Soberano de Jerusalém, pasto futuro das chamas,

1385

pára e aprende, finalmente, a reverenciar o Deus Poderoso.

Ele penetra e escuta os pensamentos mais secretos

e vê o que acontece em todo o lado. ${ }^{56}$ Mas embora demore

a consumar sua vingança sobre os ímpios, a seu tempo

derramará sua ira vingadora. Recuas

1390

voltando o rosto? A sentença está dada:

Jerusalém, inimiga da verdade, desmoronar-se-á, ela e seu povo, pasto das chamas. E ao veres as cabeças decepadas

de teus filhos, cego e ansiando ardentemente morrer,

submeterás ao jugo bárbaro teu pescoço de prisioneiro.

REI - Porque me forças a quebrar meu profundo silêncio,

ó mentiroso, pressagiando sempre catástrofes,

e a avivar repetidamente com palavras a ferida

aberta pela tua boca? Hás-de importunar causando mal-estar

a dignidade real? Não te infunde temor

1400

a sagrada majestade? Não receias a pessoa do rei

que foi ungido com uma infusão de puro óleo?

E que lamentações são essas que propalas? É só contigo

que Deus partilha seus desígnios, ignorando

a existência de outro profeta na cidade santa? Por que razão,

apenas tu, usurpas tal distinção? Vamos, onde deixas os outros?

em que posição colocas tantos anciãos?

Jeremias - Acalma-te um pouco, Soberano da mísera Jerusalém, enquanto anulo as tuas queixas com uma só palavra.

Não és tu, célebre pela tua realeza, quem eu desprezo.

Considero sagrada e venero a tua majestade.

Mas encontrando-me ao serviço do Tonante e adorando Aquele

« decori $K C T \mathbf{1 4 0 1}$ ante times] nec $K C T \mathbf{1 4 0 4}$ sancta] tanta $K C \mathbf{1 4 0 6}$ Vis occupare solus, et reliquos ubi $K C T \mathbf{1 4 0 7}$ pones $K C T \mathbf{1 4 0 8}$ Consiste] O siste $K C \mathbf{1 4 1 1}$ pudori eras. colenti $s$. $u$. / colenti est] nec pudori est KCT $\mathbf{1 4 1 2}$ Sed cum supremo seruiam regi aetheris KCT 
$\mathrm{Ab}$ arce fraudes qui coruscanti uidet

Et scelera gentis perditae, quondam suae,

1415 Amore Domini tractus et causa, ardeo

Pugnoque contra perfidos, qui crimina

Audace patrant mente nec regem meum,

Iramque subita mole ruituram timent.

R. Qui mente uiolant perfida aeternum Deum?

[p. 50]

1420 H. Qui iussa frangunt pacta.

R. Qui frangunt?

H. Tui

Qui muta cultu saxa diuino colunt.

R. Errantis ideo facinus hoc uulgi est meum?

H. Quod non prohibeas hoc scelus uulgi, est tuum.

R. Nos res profanas, arma nos reges manu

1425 Tractamus; agitent haec sacerdotes sacra.

H. Erat erat olim rex auus Dauid tuus

Idemque cultor Numinis. Qui cum scelus

Factum audiebat, regia in sella tremens

Pallebat. Eius sanguis hanc urbem tenes,

1430 Sed es in auitum corde dissimili Deum.

R. Quid uis agam?

H. Quod saepe dictum: barbaros

Expelle ritus, legibus plebem rege,

Arce furores, igne frondosos pio

Incende lucos, ense districto neca

1435 Qui tura ponunt ante peregrinos Deos.

Babylonis etiam subde ceruicem iugo.

R. O astra, tellus, arua latiuagi maris,

O quos precari Caelites fas est mihi!

Post tot labores ut iugum capiam iubes?

1440 Pietatis haec est gratia? O nimium breuis

Angusta, parca Numinis tanti manus!

H. Etiam potens, terribilis et flammae capax

Aduersus hostes.

R. Puniat. Nam cur suas

Armis Tyranni persequitur iniurias?

1445 H. Mancipia Dominus haud sua plectit manu,

$1413 \mathrm{Ab}$ arce] A sede KCT 1415 eras. tr... ante tractus 1418 ruituram] uenturam $K C T$ 1421 muta] multa $K$ / diuino] pro Deo $K C T 1422$ Quid ergo poenae facinus hoc (ob $K T$ ) uulgi est mihi? KCT $\mathbf{1 4 2 3}$ post prohibeas] R. Arma sunt regis manu KCT $\mathbf{1 4 2 4}$ Tractanda. Tractent at sacerdotes sacra KCT $\mathbf{1 4 2 5}$ om. KC 1426 rex - olim] cara religio nimis KCT 1427 -que E1; qui $E /$ om. KC 1428 om. KCT 1429 Pallebat - sanguis] Regi Dauidi, cuius 
que de sua luzente cidadela vê as fraudes

e os crimes do que foi outrora seu povo e agora se transviou, levado pelo amor e pela causa do Senhor, ardo de indignação

e luto contra os malvados que ousadamente perpetram crimes

e não receiam o meu Rei nem a sua cólera

que, num repente, se abaterá com todo o seu peso.

REI - Quem são os que perfidamente ultrajam o Deus Eterno?

JEREMIAS - Os que violam acordos firmados.

REI - E quem são eles?

JEREMIAs - Teus súbditos,

que prestam culto divino a pedras que não falam.

REI - E por isso ser-me-á imputado este crime do povo transviado?

JEREMIAS - Ao não proibires este crime do povo, participas dele.

REI - Nós, os reis, tratamos das questões civis e militares;

de questões religiosas como estas que se ocupem os sacerdotes.

JEREMIAS - Viveu outrora o rei David, teu antepassado.

Ele respeitava a divina majestade. Quando tomava conhecimento

da prática de crimes, agitando-se em seu trono real,

empalidecia. 57 Governas esta cidade como seu descendente,

mas em relação ao Deus de teus pais tens comportamento diferente.

1430

REI - Que queres que faça?

JEREMIAS - O que muitas vezes foi dito:

expulsa os ritos bárbaros; governa o povo com leis;

reprime os desvarios; ilumina os frondosos bosques

com o fogo sagrado; passa ao fio da espada

os que queimam incenso a deuses estrangeiros.

1435

Submete-te ainda ao jugo da Babilónia.

REI - Ó astros, terra, praias do mar imenso,

ó deuses celestes que me é lícito invocar!

Após tanto sofrimento, ordenas que me submeta?

É esta a paga da piedade? Ó mão demasiado curta,

limitada e fraca, de Deus tão majestoso.

JEREMias - E também poderosa, terrível e capaz de lançar fogo

contra os inimigos.

REI - Que castigue. Na verdade, porque procura

vingar com as armas do Tirano as injustiças de que é vítima?

JEREMIAS - O Senhor não castiga os seus com as suas mãos,

$\longleftarrow$ KCT 1430 Sed - auitum] At in potentem KCT 1432 legibus - rege] plebis insanae doma KCT 1433 Arce] Orci $K C \mathbf{1 4 3 6}$ Deinde Babylonis subde KCT 1439 ut - iubes] paream Assyrio iubes? KCT $\mathbf{1 4 4 1}$ manu $L \mathbf{1 4 4 3}$ Puniat - suas] Ergo cur manu suas KCT $\mathbf{1 4 4 4}$ Armis] Duri KCT 1445 haud - manu] non sua ut caedit manu KCT 
Sed fuste duro pulsat aut loro ferit.

Molitor orbis quaerit Assyrias tibi

Tuisque uirgas. Ecquid agnoscis Deum?

Cur per tyrannum cruciet haec ratio est mihi.

1450 R. O circulator, magne uanarum pater

Praestigiarum, cur mihi perdis diem

Et ira parcit?

H. Si tibi perdo diem

Inueniet ille, cuius est nox et dies.

R. Regni procul discede, turbator, mei.

1455 H. Discedo.

SAPH. Viuus ibit? Occisus cadat.

Mactare liceat ense montanam feram.

R. Omitte, uiuat. Liberet patriam fuga.

SAPH. Clementia, ubi requiritur seueritas,

Damnosa tantum regibus magnis nocet,

1460 Seueritas quantum ubi opus est clementia.

Venia redibit saeuior data haec fera.

R. O regna regi grauia, si tot temporum

Non modo procellis fluctuant, domesticae

Dissensionis sed repentinos habent

1465 Etiam tumultus. Non sinit regem feri

Suspicio belli uiuere, et uecors senex

Perturbat animum somniis, qui lucida

De sede regni fingit aetherii sibi

Mandata, contra nobile imperium mea

1470 Quod dextra fecit liberum. Impietas Deum

Si nostra magnum ritibus falsis mouet,

Ignem micantis arce siderea poli

Habet. Coruscet, fulminet, dirum tonet

Interque densas aliqua uox nubes sonet.

1475 Leges colemus rite neglectas Dei.

Sed iam uetustos patriae ritus meae,

Populo receptos mille sacrorum modos,

Vnius hominis ore mutandos putem?

1446 Sed fune torto uerberat, ita praepotens $K C T \mathbf{1 4 4 9}$ ratio] causa $K C T \mathbf{1 4 5 2}$ Et] Cur KCT 1453 Inueniat $K$ / nox et dies] nolis, uelis KCT 1454 Regni - discede] Discede regni iubeo KCT 1455 SA. Cur uiuus ibit? pestilens furia cadat KCT 1457 uiuat] sola KCT 
mas bate com um duro bastão ou fere com correias.

O Criador do universo procura vergastas assírias para ti

e para os teus. Será que reconheces Deus?

Eis para mim a razão de Ele se servir do Tirano para te flagelar.

REI - Ó charlatão, grande inventor de falsas artimanhas,

Porque me estragas o dia e és poupado

pela minha ira?

Jeremias - Se te estrago o dia

descobri-lo-á o Senhor dos dias e das noites.

REI - Afasta-te para longe do meu reino, agitador.

JEREMIAS - Afasto-me.

SAfatias - Há-de ir com vida? Matem-no.

Seja permitido passar ao fio da espada esta fera da montanha.

REI - Deixem-no viver. A sua fuga libertará a pátria.

SAFATIAS - Quando se requer severidade,

tão danosa para os grandes reis é a clemência

quanto o é a severidade quando faz falta a clemência.

Concedido o perdão, mais furiosa regressará esta fera.

REI - Oh! Que fardo, o poder real, se o agitam

em tantas ocasiões não apenas tempestades

mas enfrenta ainda tumultos inesperados

de discórdias civis. A suspeita de guerras cruéis

não deixa o rei viver e um velho insensato

perturba-lhe o espírito com alucinações; ele que

supõe receber da luzente morada do reino celestial

instruções contra o nobre império

que minha dextra libertou. Se nossa impiedade

indigna o Deus omnipotente por causa dos falsos ritos,

Ele possui o fogo na cidadela divina do luzente firmamento;

brilhem relâmpagos, caiam raios, soem medonhos trovões

e, por entre as densas nuvens, faça-se ouvir alguma voz:

cumpriremos religiosamente as leis de Deus desprezadas.

Mas acharei agora que os velhos usos religiosos de minha pátria, herdados pelo povo, os seus múltiplos rituais,

têm de ser alterados pelas palavras de uma só pessoa?

— 1463 fluctuat $L \mathbf{1 4 6 5}$ Motus, quietum non sinit (sit $K$ ) regem feri KCT 1471 magnum - falsis] falsis ritibus summum $K C T \mathbf{1 4 7 2}$ sidera $L \mathbf{1 4 7 6}$ uetustuos $K \mathbf{1 4 7 9}$ regi] regni $T$ 


\section{NvNTIVs, de Morte Ananiae Vatis}

N. O triste regi funus! O casum grauem!

[p. 52]

1480 R. Quis huc dolorem portat et funus gemit?

N. Populi leuamen unicum nostri occidit.

R. Adesto. Quid uis? Ecquid apportas mali?

N. Funesta maeret Solyma.

R. Quid causae est?

N. Tuus

Amicus obiit.

R. Quis?

N. Dei interpres, tibi

1485 Gratus Ananias.

R. Obiit?

N. Haud pridem, modo.

Efflauit animam

R. Morte qua?

N. Mortis genus

Non est apertum.

R. Periit aut morbo, aut manu?

N. Auctore nullo periit; extinctum scio, Sed non peremptum ui manuque. Frigidum

1490 Horret cadauer.

R. Poculo nocentia

Aconita diro forsan incautus bibit.

N. Nullo ueneni corpus indicio iacet.

R. Deflenda narras.

N. Fama trepidantis uolat

Per ora uulgi sparsa cuiusdam minis

1495 Cecidisse uatis.

R. Plura ne dicas. Sat est.

Illa illa regni Furia ui magica meum In fata uatem pepulit. O fraudem senis! Ita mihi carum morte surripuit caput? Ego nunc parabo funeris honorem tibi,

1500 Tibi o meorum magne fatorum pater.

Animi sed atrox ille delusor mei

Impune facinus haud diu tantum feret.

1481 nostri] maesti KCT 1482 Quid uis?] iuuenis KCT 1483 Quid - est?] Quae clades? KCT 1484 Obiit amicus nempe factorum (fatorum K) comes KCT $\mathbf{1 4 8 5}$ Gratus] Fidus KCT 1486 Efflauit] Adflauit $K \mathbf{1 4 8 7}$ Periit - manu] Perge, dic cuius manu. $K C T$ / aut] an $L$ 
CENA VIII: Mensageiro, com a notícia da morte do profeta Ananias ${ }^{58}$

Mensageiro - Triste morte para o rei! Ai! Que grande desgraça!

REI - Quem traz a dor para aqui, lamentando uma morte?

Mensageiro - Morreu a única consolação do nosso povo.

REI - Aproxima-te. Que queres dizer? Que más notícias me trazes?

MENSAGEIRo - Jerusalém chora tristezas.

REI - Qual o motivo?

Mensageiro - Teu

amigo morreu.

REI - Quem?

Mensageiro - O profeta de Deus,

o teu querido Ananias.

1485

REI - Morto?

Mensageiro - Não há muito

exalou o último suspiro.

REI - Como morreu?

Mensageiro - O tipo de morte

não é claro.

REI - Morreu de doença ou à mão armada?

Mensageiro - Ninguém o matou; sei que está morto

mas sem que o tenham assassinado violentamente. Já frio,

o cadáver dá um aspecto horrível.

1490

REI - Porventura bebeu,

de alguma sinistra taça,sem saber, um veneno poderoso?

Mensageiro - O corpo não apresenta quaisquer indícios de veneno.

REI - É lastimável o que me narras.

Mensageiro - Voa a fama nas vozes do povo

em alvoroço de que terá morrido devido às ameaças

de certo profeta.

REI - Não digas mais; já basta.

Foi aquela Fúria do reino, com seus mágicos poderes,

que atirou para a morte o meu profeta. Velho traiçoeiro!

Arrebatou-me assim pela morte alguém que me era tão caro?

Preparar-te-ei agora honras fúnebres dignas de ti,

ó grande protector dos meus oráculos.

1500

Mas aquele atroz ilusionista do meu espírito

não ficará muito tempo sem pagar crime tão grande.

$\longleftarrow \mathbf{1 4 8 9}$ Scio nec peremptum fraude nec ferro, integrum $K C T \mathbf{1 4 9 0}$ Cadauer alget. R. Poculi nocentia KCT 1491 diri KCT 1492 Nullam ueneni corpus ostendit notam KCT 1494 cuiusdam] fatidici $K C T \mathbf{1 5 0 0}$ magne E1; maxime $E$ / magne fatorum] maxime sacrorum $K C T$ 


\section{ChORVS IN FVnere \\ (Efertur cadauer Ananiae)}

Triste cupresso tibi luctuosa

Funus inducit chorus, o sacerdos.

1505 Te genis unda saliente plangit.

[p. 53]

Mortuis uiui dare iusta possunt

Et pio corpus sepelire ritu.

Haec habe. Fama memori uigere

Sola dat numquam tumulanda uirtus.

1510 Foeda quem labes animi peremit,

Criminum dira nece funeratum,

Non sepulturae decus expiabit.

Fama corruptae putrefacta mentis

Semper exhalat, licet inuolutum

1515 Balsamo spiret bene olente corpus.

Longa uoluetur rota saeculorum,

At tuum numquam scelus obsolescet.

Quo facis regem sceleratiorem,

Nec Dei iussis magis annuentem,

1520 Quam flagellatas mouet unda cautes,

Africo plangens adigente litus.

Vnde iam belli propiore flamma

Ciuitas ardet, Babylonque nudo

Imminet ferro, Solymam datura

1525 Ignibus urbem.

I, uale extrema cape uoce longum.

Teque non sero miseri sequemur.

Heu dolor. Ciues aliena flemus

Damna lamentis. Vbi nostra? Nobis

1530 Personent aurae, quibus est luendum.

Quicquid insano furit aula motu.

Barbaro peccant animo tyranni.

Nos trucidamur iuguloque caeso

Tingimus enses. 


\section{Coro Fúnebre \\ (Transporte do cadáver de Ananias)}

Com os ciprestes em luto por ti, ó sacerdote, o coro faz avançar triste cortejo fúnebre.

Com os rostos banhados em lágrimas, ele chora por ti.

1505

Os vivos podem prestar homenagem aos mortos

e dar-lhes sepultura com piedosos rituais.

Atenta nisto: que se viva com fama duradoura

apenas o permite a virtude que ninguém pode jamais sepultar.

Quem sucumbiu a vergonhosa desonra do espírito

1510

cruelmente vitimado por seus crimes

não será compensado pela beleza do seu jazigo.

A fama putrefacta de sua mente corrupta

espalha-se sempre ainda que exale aromas

o corpo envolto em bálsamo perfumado.

1515

Passará o tempo na longa roda dos séculos

mas da memória jamais se apagará teu crime

que faz o rei tornar-se mais criminoso

e menos dócil às ordens de Deus

do que as impassíveis rochas flageladas pelas ondas,

1520

do que os litorais queixando-se fustigados pelo Áfrico. ${ }^{59}$

Por isso, em chamas iminentes de guerra

arde já a cidade e Babilónia ergue-se

de espada nua para lançar no fogo

a cidade de Jerusalém.

Vá! solta em derradeiro grito um longo adeus

e nós te seguiremos, não tarda.

Ai, quanta dor! Nós, cidadãos, choramos

com lamentos castigos alheios. Quando choraremos os nossos?

Traz-nos o vento todo o desvario que alvoroça a corte

1530

e pelo qual seremos castigados.

Os tiranos desonram-se com atitudes bárbaras.

Somos trucidados e tingimos as espadas

com o sangue de nossas gargantas. 


\section{ACTVS TERTIVS}

\section{Hieremias. OracVlvm}

1535 H. Quo plus laboro uiribus fractis senex, In hoc monendo rege, cui Furiae obruunt Mentem tenebricosa inferum caligine, Eo, o corusci Conditor Olympi, magis Aduersa iussis pectora inuenio tuis.

1540 Iudaea gens o peior ignaris Dei

Populis auiti! Colere quae nescit suum Gens rite Numen, pro Deo truncos licet Et saxa uariis uncta pigmentis colat. Tu Solyma nescis, perfida, ingrata, impia, 1545 Tu sola nescis colere quem debes Deum, Deus ille ueterum more uenerandus fuit, Qui rubra secuit inuii ponti uada Auosque Pharia gente demersa, dedit Habitare pinguem fertilis glebam soli, 1550 Vbi lacte niuei plurimo riui fluunt Et mella cautes flaua rimosae liquant. Quae dira repens pestis in praecordia Patrii timendum numen aboleuit Dei? Quo me gementem conferam? Bellum domi,

1555 Forisque bellum personat. Vatem mori Deus alme fas sit. Patriae satis dedi Vitae et laboris prodigus. Quid imperas, Aeterne Genitor? Quo hanc senectutem trahis?

O. Huc oculos attolle, uago quid in aere cernis?

1560 H. Pendere calathos uideo ficorum duos. Calathusque ficos dexter ostendit bonas, Malas sinister. Propius apparent, patet

1535 scae. non ind. C 1537 mente $K \mathbf{1 5 3 8}$ eras. plu post eo C $\mathbf{1 5 4 0}$ Iudaea gens o] O gens hebraea KCT 1542 licet] litet $K \mathbf{1 5 4 3}$ colat $K \mathbf{1 5 4 5}$ debes] spernis KCT 1547 post. secuit] in uias pelagi KCT 1550 plurimo] candido KCT 1551 rimosae] montanae KCT / linquent 


\section{ACTO III}

\section{CENA I: JEREMIAS E ORÁCULO 60}

JEREmias - Quanto mais me empenho, eu, um velho combalido, em advertir este rei, cuja mente as Fúrias bloqueiam com uma tenebrosa nuvem dos Infernos, mais encontro, ó Criador do Olimpo repleto de estrelas, pessoas opondo-se às tuas ordens.

Ó gente de Judá, pior que os povos que ignoram

o Deus de nossos pais! As nações que não sabem adorar devidamente a divindade, que em vez de Deus adorem troncos e venerem pedras pintadas de várias cores. Tu, Jerusalém, pérfida, ingrata e sacrílega, só tu não sabes adorar o Deus a quem deves adoração,

o Deus que deverias adorar à maneira dos antepassados, Ele que abriu passagem pelos ínvios fundos do Mar Vermelho e, fazendo desaparecer nas águas a gente do faraó, concedeu aos nossos pais que habitassem uma terra de solo fértil onde correm cristalinos rios de abundante leite e das fendas das rochas escorre mel dourado. ${ }^{61}$ Que veneno infiltrado em tuas cruéis entranhas te levou a esquecer o temível poder do Deus de nossos pais? Para onde lançarei meus gemidos? Na minha pátria, é a guerra; fora dela é a guerra que ressoa, ó Deus propício.

Deixa que teu profeta morra. Eu dei à pátria muita vida e sofrimento. Que me ordenas, Eterno Criador? Para onde arrastas esta velhice?

OrÁculo - Ergue teus olhos para aqui. Que vês tu pairando no ar?

JEREMIAS - Vejo suspensos dois cestos de figos, e o cesto da direita apresenta figos bons; o da esquerda, maus. Surgem mais perto

— K 1553 tremendum nomen $K C T \mathbf{1 5 5 6}$ fas sit] sinito $K C T \mathbf{1 5 5 7}$ Quid] Queis $K \mathbf{1 5 5 9}$ uago] tuos KCT 1560 Pendere] Hinc ipse KCT 1561 bonos $T$ 
Discrimen ingens. Dexteri calathi optimae

Calathi sinistri pessimae haud mandi queunt.

[p. 55]

1565 O. Haec igitur canit aeternis qui legibus orbem

Temperat et quotiens uoluit tremefecit Olympum.

Sicut habet calathus felici ex arbore ficos

Dexter et in mensas gratissima poma ministrat,

Sic ego praeterita quos obsidione coegi

1570 Imperium et regis Babylonia uincula ferre,

Hos sorte in patriam citius meliore reducam.

Quin etiam me nosse dabo, quo gens mihi sancta

Viuat, et illa Deum me praedicet esse colendum.

Verum infelices fatuo de germine ficos,

1575 Ora uelut tristi renuunt inimica sapori,

Sic procul est animus Solymorum auertere regem.

Occumbant etiam Phariae quibus oppida terrae

Tuta uidebuntur. Diuersa ergastula mundi

Captiui implebunt. Lacerent hic uerbera tergum;

1580 Illic sint dominis ludibria longa superbis.

Hos gladii hostiles, hos letifer auferat annus,

Donec ab antiquae discedant finibus orae,

Quam genus ingratum et praui tenuere nepotes.

H. O dura, grauia, saeua, perpessu aspera,

1585 Quae cogitasti gentis in cladem tuae!

Quis illa compos mentis accipiet suae?

Quis non fatiscet? Opprimit memet dolor,

Et ossa neruis quassat infractis timor.

Nec corpus animum fragile labentem tenet,

1590 Nec animus aegrum uiribus corpus regit.

Sedens tremensque lugeo et lugens tremo.

O. Longa tuli patiens durae fastidia gentis,

Iam scelerum eluuio, iam nausea prouocat iram.

Vindictaeque locum dare pergo. Sume lagenam

[p. 56]

1595 Ergo tibi luteam et procerum uulgique coacto

Concilio intrepida lingua mea dicta loqueris.

H. Graue est redire rursus ac totiens uadum

Tentare numquam pedibus inuentum meis

Sunt duriores silice litorea mihi

1564 mandi] edi KCT 1568 mensa $K \mathbf{1 5 7 2}$ nosce $L \mathbf{1 5 7 4}$ Verum] Ast $K C T$ / fatuoque e germine $K C T \mathbf{1 5 7 6}$ regem] gentem $K \mathbf{1 5 7 8}$ uidebantur $K$ / mundi] terrae $K \mathbf{1 5 8 6}$ compos - suae] mentis impos attonitae audiat KCT 1587 Qui C / fatiscat KCT / memet] mentem 
e nota-se grande diferença. Os do cesto da direita são óptimos; os do cesto da esquerda péssimos, incomestíveis. OrÁculo - Eis então o que anuncia Aquele que regula o universo com leis eternas e fez tremer o Olimpo as vezes que quis:

da mesma forma que o cesto da direita ostenta figos de árvore fecunda e fornece agradáveis frutos para as mesas, também aqueles a quem eu obriguei, no anterior cativeiro, a suportar a autoridade e as algemas do rei da Babilónia, eu os reconduzirei bem cedo à sua pátria com melhor sorte. E mais ainda: dar-me-ei a conhecer para que esse povo viva consagrado a mim e me proclame como o Deus digno de adoração. Mas quanto aos figos mirrados vindos de insípidos rebentos, da mesma forma que as bocas os rejeitam, por seu péssimo sabor, assim é intenção minha afastar para longe o rei de Jerusalém.

Sucumbam ainda as cidades fortificadas do Egipto

para quem as considerar seguras. As várias masmorras do mundo encher-se-ão de cativos. Num lado, dilacerem-lhes as costas azorragues; noutro, sejam motivo de forte zombaria para seus orgulhosos senhores. Façam-nos desaparecer, a uns a espada inimiga, a outros um ano mortífero, até que abandonem as fronteiras de seu velho país habitado por raça ingrata e por descendentes depravados. JEREMIAS - Que acontecimentos duros, penosos, cruéis, difíceis de suportar os que tu pensaste para a ruína de teu povo!

Quem os aceitará sem perder a serenidade de espírito?

Quem não desfalecerá? Aflige-me a dor

e o medo sacode-me os ossos, pondo-me os nervos em franja.

Nem o corpo enfraquecido me segura a mente oscilante,

nem a mente dirige o corpo falho de forças.

Sentado e a tremer choro, e a chorar tremo.

OrÁCUlo - Tolerei pacientemente o longo desprezo dum povo insensível.

A quantidade imensa de crimes, a náusea que sinto, atraem já minha cólera

e apresso-me a dar lugar à vingança. Pega na tua bilha de barro

e anuncia intrepidamente as minhas palavras

ao povo e aos nobres reunidos em assembleia.

JEREMIAS - É-me penoso regressar de novo e tocar tantas vezes

em terreno nunca pisado pelos meus pés.

Para mim são mais duros do que as rochas dos litorais ${ }^{62}$

— KCT 1588 infractis] effractis CT 1592 fastigia $K \mathbf{1 5 9 3}$ irae KCT 1594 Vindictaeque] Iustitiaeque KCT 1595 tibi s. u. C $\mathbf{1 5 9 7}$ ac] et KCT $\mathbf{1 5 9 9}$ Sunt et mg. $C$ 
1600 Huiusce Sodomae barbarae inuisi incolae.

Sed quis recuset ire si mandat Deus?

O. Vade age, dic sacris quoniam deuota nefandis

Vrbs operata, meas contempsit adultera leges,

Propterea ecce dies ueniunt, Deus inquit, et omnem

1605 Hanc terrae faciem mutabo et nomina demam.

Qua uallis depressa iacet (mora temporis arta est)

Strata cateruatim ducentur corpora uulgo,

Et breuiter summos aequabunt funera montes.

Tunc ea uallis erit morientum clara sepulcris

1610 Sumet et aeternum stagnante a sanguine nomen

H. Ne plura, Vindex magne, percussae horrido

Instar tubarum tinniunt aures sono.

Labascit animus cladis auditae memor.

O. His non arcet adhuc feruentem terminus iram;

1615 Consilium, uires, atque arma imbellia reddam.

Hostili sub Marte cadent nec honore sepulcri

Condentur. Mediis inhumata cadauera campis

Vulturiis fuerint nemorumque leonibus esca.

H. Horresco; mentem reddit attonitam pauor.

1620 O. Hoc quicumque solo stratam conspexerit urbem,

Reliquiasque breues flammae, miratus abibit

Sibilaque explodet labiis stridentibus ora.

H. Vt recta sequitur facta praeclarum decus,

Ita praua damnat acta diuturnus pudor.

1625 O misera Solyma, post grauem cladem exteri

Spernente ludent sibilo te dirutam.

O. Quin ubi munito cingentur moenia uallo

Intendentque leues castrensia uela rudentes,

Dira fames adeo grassabitur, ut pater artus

1630 Scindat quos genuit uerubusque trementia figens

Viscera tosta uoret, domet ut ieiunia uentris.

Oblitusque olim sociae commercia uitae

Carnibus erepti se pascet amicus amici.

H. O esca in ipsis execranda belluis!

1635 Huc scelera tendunt? Filium mandet pater

Suaque uorabit uiscera? O dirum nefas!

1600 Huius KCT 1601 recuset - mandat] retractet iussa, si iubet KCT 1602 quoniam sacris $K C T \mathbf{1 6 0 4}$ Deus s. $u . K \quad \mathbf{1 6 1 0}$ stagnanti $K C T /$ a] e $K \quad \mathbf{1 6 1 1}$ Ne et $m g$. C $\mathbf{1 6 1 4}$ His - adhuc] Non is adhuc claudit KCT 1615 atque] ac $K T \mathbf{1 6 1 6}$ Marte] morte $L 1618$ Vultureis 
os odiosos habitantes desta bárbara Sodoma. ${ }^{63}$

Mas se Deus o ordena, quem se recusará a avançar?

OrÁculo - Vai, coragem, fala, uma vez que a cidade, toda entregue a rituais abomináveis, despreza minhas leis como uma prostituta.

Por isso, diz Deus, dias virão em que mudarei totalmente

esta face da terra e lhe retirarei os nomes.

1605

Onde um vale se afundar (e já pouco falta)

estender-se-ão por todo o lado montões de corpos

e em pouco tempo os cadáveres nivelarão os cimos dos montes.

Nessa altura, este vale ficará famoso pelas sepulturas de seus mortos e assumirá para sempre um nome derivado do sangue que o inunda. ${ }^{64}$

JEREMIAS - Não digas mais, grande juiz; atingidos por som horrível, como o de trombetas, meus ouvidos zumbem.

Desfalece-me o espírito ao evocar a destruição anunciada.

ORÁculo - Minha cólera ardente ainda não se afastou deles;

tornarei ineficazes seus planos, suas tropas e suas armas.

1615

Eles morrerão sob os golpes do inimigo e nem com sepultura

serão honrados. Serão cadáveres abandonados no meio dos campos,

alimento para os abutres e para os leões das florestas. ${ }^{65}$

JEREMIAS - Estremeço de horror; o medo deixa-me atónito.

OrÁCUlo - Quantos contemplarem a cidade arrasada

1620

afastar-se-ão, impressionados com os resíduos deixadas pelas chamas,

e farão sair de seus lábios sons de assobios. ${ }^{66}$

JEREMiAs - Tal como boas acções deixam uma memória enobrecida, também acções indignas ficam condenadas a longa infâmia.

Ó infeliz Jerusalém, após tua grande desgraça,

os povos estrangeiros zombarão de tua ruína com assobios de desprezo.

ORÁCUlO - Mais: quando rodearem as muralhas com fortes trincheiras

e leves cabos prenderem os barcos de guerra,

grassará fome tão cruel que os pais dilacerarão

os membros de seus filhos e, assando no espeto vísceras palpitantes,

1630

devorá-las-ão para saciar a fome do seu estômago.

$\mathrm{E}$ os amigos, esquecendo relações de amizade,

alimentar-se-ão da carne dos amigos capturados. ${ }^{67}$

JEREMIAS - Ó alimento execrável entre as próprias feras.

Os crimes chegam tão longe? Os pais comerão os filhos, devorando-lhes as próprias entranhas? Sacrilégio horrível!

$\longleftarrow K$ / fuerint] aderunt KCT $1620 \mathrm{Hoc}]$ Sic KCT 1623 praeclarum] perpetuum KCT $\mathbf{1 6 2 4}$ damnat] sequitur KCT 1625 cladem] poenam KCT 1627 moenia] pergama KCT 1631 tosta] costa $L$ 1633 erepti] exempti $K$ 
Cui ne superstes maneat hic rerum decor.

Inuolue mundum sub tenebroso chao.

O. Vade, age, quam dixi populo spectante lagenam

1640 Frange. Deo, clama, manet alta mente repostum,

Sic urbem durumque genus confringere, testa

Fracta uelut nulla figuli renouabitur arte.

H. Quam dira porto! quam grauem molem fero!

Non sol coruscum luce qui prona diem

1645 Colligit in undas aequoris Hiberi ruens

Se penitus umbra noctis occidua teget,

Quam me superbis Ducibus et Regi offeram,

Acerbiora iussa dicturus Dei

Quam credat aliquis. Ita triumphantem sinam

1650 De me Deoque perditum regem? Male

Male cogitatis principes; nefario

Erratis animo. Vestra pernicies domet

Vos insolentes, quando nec potest salus

Nec ipse mentem flectere malorum timor.

[p. 58]

\section{Hieremias. PVER}

1655 H. Age, rege gressus o puer ad urbem meos.

P. Vulgi furorem regis insidias time.

H. Nescit homines timere qui paret Deo.

P. Nil profuturum uadis in periculum.

H. Satis est tremendam canere uindictam Dei.

1660 P. Vindicta surdis respuetur auribus.

H. Suo audietur tempore.

P. At differ suo.

Monere non est rege Sedecia locus.

H. Erit, erit. Illum respice in celso arbitrum

Solio sedentem. Qualis Armeniae leo

1665 In nemore denso impastus ad praedam ruit

Praedaeque rictus sanguine uoraces lauat,

Non aliter ille conditor Olympi aurei,

Ob scelera nostrae gentis, irarum calet

1637 supestes $T \mathbf{1 6 3 9}$ spectante] aspiciente $K C T \mathbf{1 6 4 1}$ dirumque $K$ / constringere $L$ 1647 offeram] feram $K \quad \mathbf{1 6 5 3}$ nec] non KCT 1654 Nec ipse rectam flectere in mentem Deus KC 1655 gressus] passus KCT 1657 paret] colit KCT 1659 tremendi $K C T 1661$ Et $K C T$ 
Que não lhes sobreviva esta beleza do mundo por Ti criado.

Sepulta o mundo em tenebroso caos.

Oráculo - Vamos, quebra perante o povo a bilha de que falei.

Grita bem alto: É firme intenção de Deus

aniquilar assim a cidade e sua ímpia gente, tal como esta bilha:

uma vez quebrada, jamais poderá repará-la a arte de qualquer oleiro.

JEREMIAS - De que terríveis notícias sou portador! Que peso enorme transporto!

O Sol, que nos traz o dia derramando sua luz,

descendo de encontro às ondas do Mar Ibérico,

não se ocultará de todo na sombra da noite a ocidente,

sem que me apresente diante dos ilustres generais e do rei

para lhes dar a conhecer ordens de Deus mais terríveis

do que alguém poderá supor. Um rei descontrolado

triunfando assim de mim e de Deus, hei-de tolerá-lo?

1650

Estais muito enganados, príncipes. Persistis na vossa maldade.

Que a vossa ruína esmague a vossa insolência,

já que nem o bem-estar, nem mesmo o medo das desgraças

consegue alterar a disposição de vosso espírito.

\section{CENA II: JEREMIAS, MoçO}

JEREMias - Vamos, rapaz, conduz meus passos para a cidade.

Moço - Teme a fúria da multidão e as insídias do rei.

JEREMIAS - Quem se encontra às ordens de Deus não sabe recear os homens.

Moço - Vais ao encontro de perigos que nenhum proveito te trarão.

JEREmias - Basta-me anunciar a terrível vingança de Deus.

Moço - Os ouvidos surdos não farão caso dessa vingança.

JEREMias - A seu tempo escutarão.

Moço - Adia para essa altura.

Enquanto Sedecias for rei não é altura de fazer advertências.

Jeremias - Há-de ser, há-de ser. Repara no Juiz sentado

em seu trono excelso. Tal como um leão da Arménia

se precipita, esfomeado, sobre a presa na densa floresta,

e lava no sangue desta suas goelas vorazes,

do mesmo modo o Criador do brilhante Olimpo,

face aos crimes de nosso povo, agita-se

« 1662 Monere] Monendi $L$ / rege Sedecial rege sub tali $K C T \mathbf{1 6 6 3}$ celso] caelo $K$ 1664 sedentem] micantem $K C T \mathbf{1 6 6 5}$ In] E $K C T$ / ruit] furit $K C T \mathbf{1 6 6 8}$ iratum $K C$ / calet] aestuat KCT 1669 Flammatus aestu] Vasto in camino KCT / celsa] rutila KCT 
Flammatus aestu. Sede de celsa caput

1670 Regale praeceps aspero casu dabit

Pedibusque gentis exterae uilissimis

Submittet. Illis ardui pinnis lares,

Illaeque turres, illa propugnacula

Ambusta flammis concident uoracibus.

GEDELIAS, speculator ad hostem missus, redit ad Regem.

HiEREMIAS. PVER

1675 H. Quis implet aures bucinae raucae canor?

P. Inflat recuruam bucinam uasto grauis

Ore Gedelias, missus in terram hosticam

Speculator.

H. Audi quid boni aut mali ferat.

GED. Via peracta redeo, non laetum tamen

1680 Regi daturus nuntium. Quicquid potest

Babylon in armis, uertici id nostro imminet.

H. En iam propinqua fumat ira Numinis.

GED. Nabucdonosor castra quam latissima

Ductor mouebat acer. Innumeros equos

1685 Frenabat. Aequat aequoris arenam pedes.

H. Iam uera fiunt capitis huius somnia.

GED. Eo apparatu nos ferox unos petit.

Maiore numquam uisus inimicae plagas

Gentis adiisse. Vereor ut Solymi cadant,

1690 Peiusque uicti seruiant tyrannidi,

Quam nunc rebellant. Aleam iecit semel

Rex noster, omnem sortis euentum ferat.

Proinde quando iam rebellauit, meum est

Regem monere fortis ut bellum gerat.

1695 H. Id si monebis, se quoque ut iugulet mone.

GED. Per iniqua et aequa gloriae constat uia.

Audere regem fortia inuictum decet,

Non seruitutem gentis alienae pati.

Ad magna dominos trahere generosos licet.

1674 post Ambusta] flamma penitus urenti cadent KCT 1675 scae. non ind. C implet] turbat KCT $\mathbf{1 6 7 6}$ bucinae $L \mathbf{1 6 8 2}$ En iam Tonantis ira calefacta aestuat KCT 1683 quam] iam KCT $\mathbf{1 6 8 4}$ monebat $E \mathbf{1 6 8 7}$ Eo s. $u$. $K$ / ferox unos] graui (graue KT) ad bellum KCT 1688 Maiora $L$ / plagas] oppida KCT 1691 ante Aleam] Qui KCT 1692 Rex noster] Patienter 
no calor da sua cólera. ${ }^{69}$ De sua excelsa morada,

Ele trará à existência do rei pesada ruína, 1670

sujeitando-a à mail vil escravidão, sob nação estrangeira.

Aquelas altas moradias e suas ameias,

aquelas torres, aquelas elevadas fortalezas

ruirão lambidas por chamas vorazes.

CENA III: GEDELIAS (enviado a espiar o inimigo, volta para junto do Rei) JEREMIAS, MOÇO.

JEREMIAS - Que som estridente de trombeta me chega aos ouvidos? 1675 Moço - Quem sopra a plenos pulmões em sua recurva trombeta é Gedelias, o espião enviado ao território inimigo.

JEREmias - Escuta o que de bom ou mau ele anuncia.

GEDELIAS - Feita a viagem, regresso, mas não para comunicar boas notícias ao rei. Todo o poderio militar da Babilónia 1680 pesa sobre nós como uma ameaça.

JEREMIAS - Eis que já fumega bem perto a cólera da divindade.

GEDELIAS - Nabucodonosor comandava energicamente extensíssimos arraiais; segurava inúmeros cavalos em seus freios.

A infantaria é tão numerosa como a areia do mar. ${ }^{70}$

JEREMIAS - Já se tornam reais as fantasias desta cabeça.

GEDELIAS - Com este aparato procura-nos, só a nós, ardendo em fúria.

Não tendo visto nunca nada maior a dirigir-se para território de nações inimigas, receio que os habitantes de Jerusalém sucumbam e que, uma vez vencidos, fiquem sujeitos a pior tirania 1690 do que aquela contra a qual se revoltam agora. Lançou já os dados ${ }^{71}$ o nosso rei. Aceite o desfecho da sorte, qualquer que seja.

Uma vez que já se revoltou, compete-me exortá-lo a que faça a guerra com coragem.

JEREMIAS - Se o fizeres, recomenda-lhe também que corte o pescoço. GEDELIAs - O caminho da glória tem momentos atribulados e serenos. Fica bem a um rei invicto aventurar-se a feitos corajosos, não aceitando servidões impostas por nações estrangeiras. É lícito atrair para grandes feitos os nobres soberanos.

« KCT 1693 iam - est] est iam rebellatum semel KCT 1694 monere] monebo KCT / gerat] ferat KCT 1698 gentis alienae] Regis alieni KCT 1699 dominos - generosos] Regem trahere generosum $K C T$ 
1700 Id arbitrabor esse uirtutis meae.

H. Quaenam illa uirtus impudens in qua scelus

Spectatur? Istum quid moror? Magnum petam

Regum magistrum.

GED. Cuius os uides senis?

H. Sedatus animo adesto, si nosti meum.

1705 Quando arbitraris esse uirtutis tuae

Ad magna dominos trahere generosos, rogo

Ad scelera credis esse probitatis tuae

Impellere animum regis? Ab Olympo Deus

Bellare prohibet, arma tu contra Deum

1710 Tractare clarum et regium factum putas?

Bone Gedelia, si tui instantem uident

Oculi ruinam patriae et castris ferae

Babylonis aciem dicis instructam; potens

Nabucdonosor arma si quatit luem

1715 Paritura certam cur ab insano trahis

Consilia cepto? Rege cum misero, domos

Solymaeque populum sponte praecipitem dabis?

Praedico moneo Numinis iussu mei,

Quod sceptra regni clara stellantis tenet:

1720 Peristis omnes, arma corripitis manu

Si paenitenda. Ponite, hoc mandat Deus.

GED. Mandasse quisnam testis?

H. Is qui praeuidet

Vates futura scilicet, testis tibi est.

GED. Feremus ergo gentis Assyriae iugum?

1725 H. Ne duriora nempe cogamur pati.

GED. Quod seruitute maius infami malum?

H. Miserum cadentis patriae excidium tuae.

GED. Cadente patria dulce credamus mori.

H. Extare uobis illa seruatis potest.

1730 GED. Non est salus seruire, sed longa diem

In morte miserum trahere.

H. Respiciet Deus.

Meliora forsan Genitor adflictis dabit

1702 Notatur $K C T$ / Istum] Ictum $L$ / quid - petam] nempe iam regum petam $K C T$ 1703 Regum] Magnum KCT / God. pers. L G. pers. KCE / Cuius intueor gradus KCT $\mathbf{1 7 0 4}$ ante Sedatus] eras. Gradus C / Sedato K / meum] meos KCT $\mathbf{1 7 0 6}$ dominos] regem KCT / generosos] generosum $K C T \mathbf{1 7 1 6}$ domum $K C T \mathbf{1 7 1 7}$ populum sponte] plebem ruere $K C T \mathbf{1 7 1 8}$ Niminis iussu] regis imperio $K C T \mathbf{1 7 1 9}$ Quod] Qui $K C T$ / stellantis] syderei $K C T \mathbf{1 7 2 0}$ Periistis $K$ 1721 hoc] id KCT 1722 G. pers. KCTE Godolias pers $L$ / testis] retulit $K C T$ / Is qui praeuidet] 
Tomarei isso como sendo virtude minha.

JEREMIAS - Desavergonhado, que virtude tem em vista o crime?

Porque me demoro com ele? Irei ao encontro do grande mestre dos reis.

Gedelias - De quem é esta cara de velho que estás vendo?

JEREmias - Mantém-te calmo, se reconheceste meu rosto.

Uma vez que é precisamente virtude tua

arrastares os nobres soberanos para grandes feitos, pergunto-te:

acreditas que é honrado, da tua parte, levar à prática de crimes

o espírito do rei? Deus, lá do Olimpo, proíbe a guerra;

mas tu consideras que erguer armas contra Deus

é um feito notável e digno dum rei.

1710

Bom Gedelias, se teus olhos vêem como iminente

uma desgraça abatendo-se sobre a pátria, e nos arraiais,

como dizes, o exército da feroz Babilónia está pronto para a guerra;

se o poderoso Nabucodonosor brande armas

que trarão desgraça certa, porque retiras ensinamentos

de desígnios insensatos? Juntamente com o miserável rei, vais

precipitar conscientemente na desgraça os lares e o povo de Jerusalém?

Eu prego, admoesto por ordem do meu Deus

que detém os ceptros reluzentes do reino das estrelas:

estais todos perdidos se recorrerdes às deploráveis armas.

Ponde isso de lado. É Deus quem o ordena.

GEDELIAS - Que garantias há disso?

JEREMIAS - Este profeta, sem dúvida,

consciente do futuro; é ele quem te dá garantias.

GEDELIAS - Suportaremos então o jugo da nação assíria?

JEREMIAS - Precisamente, para não termos de suportar coisas bem piores. 1725

GEDELIAS - Existe desgraça pior do que uma servidão infame?

JEREMIAS - A triste destruição de tua pátria moribunda.

GEDELIAS - Confiemos que será agradável morrer com a pátria moribunda.

JEREMIAS - Ela poderá permanecer se vós vos conservardes.

GEDELIAS - Servir não é vida, mas, em morte lenta,

arrastar miseravelmente seus dias.

JEREMiAs - Deus estará atento.

O Criador dará, certamente, melhor sorte aos aflitos.

« Aetheream dedit KCT $\mathbf{1 7 2 3}$ Cui praeuidendi, qui potest mentem dare KCT $\mathbf{1 7 2 4}$ G. pers. CE Ge. pers. $K T$ Godolias $L /$ gentis Assyriae] Regis Assyrii $K C T \mathbf{1 7 2 5}$ nempe cogamur] damna possitis $K C T \mathbf{1 7 2 6}$ G. pers. $C E$ Ge. $K$ Gedelias $L /$ seruituti $C L /$ infami] infami est $K C T$ $\mathbf{1 7 2 7}$ Miserum] Mors et $K C T \mathbf{1 7 2 8}$ G. pers. $C E$ Ge. $K T$ Gedelias $L /$ credemus $K C T$ 1730 G. pers. CE Ge. KT Gedelias $L 1731$ respicit $T \mathbf{1 7 3 2}$ forsan] post haec KCT 
GED. Nunc sit misericors et mala auertat pius.

H. Estis inimici.

GED. Fecerit amicos.

H. Bene.

1735 Facinora fugite. Scelera uobis id negant

Obstatque pietas pulsa de patrio solo.

Reuocate, ueniat: ipse se lenem dabit

Genitor amicum. Cum puduit olim sui

Nostros parentes sceleris, ipse ultro Deus

1740 Infensa ualida castra deleuit manu

Cadaueribus ipsa obruens tentoria.

Vna peremit nocte quis tot millia

Senachiribi regis ex exercitu?

Id fecit Ales unus imperio Dei.

1745 Auferte scelera; mente sincera ad fidem

Redite priscam. Bella pro uobis gerent

Deo imperante militum caelestium

Agmina, citatis illa quae pennis uolant.

GED. Excors senecta corde furiato, sile

1750 Et fabulosis parce me miraculis

Obruere. Regem bella tractantem sine.

Tua mens caduca sola sit curae tibi.

H. Miracula illa fabulas uocaueris?

Ita res auorum prauus exornas nepos?

1755 Age te relinquo. Vade. Si quantum mea

Sapit senectus, regii tantum duces,

Rexque ipse saperet, mente coleretis Deum

Propensiore. Tunc domi pax floresceret.

Aut si quis hostis rueret et bellum ferox

1760 Inferret, illum protinus contunderent

Celeres ministri iussa qui peragunt Dei.

GED. Fuge! Fuge! tecum tristia exporta omina.

Nec pax in ore nec salus ulla est tuo.

H. Ne te fatiga; fugio dicturus tamen

1765 Acerbiora. Linquo quos liquit Deus.

GED. O dura patriae fata! Cur semper feros

1733 G. pers. $C E$ Ge. $K T$ Gedelias $L \quad \mathbf{1 7 3 4}$ G. pers. KCE Ge pers. $T$ GED. pers. $L /$ fecerit] Ergo faciet $K C T$ / Bene] uolet $K C T \mathbf{1 7 3 5}$ Si scelera fugitis, sceleris hanc uobis negat $K C T$ 1736 Dira pietatem noxa (culpa $K T$ ), cum puduit sui $K C T$ 1737-1738 om. KCT $\mathbf{1 7 3 9}$ Olim parentes criminis, Deus hostium KCT $\mathbf{1 7 4 0}$ Infensa castra caede funesta obruit KCT $\mathbf{1 7 4 1} \mathrm{om}$. KCT $\mathbf{1 7 4 3}$ ex exercitu] aetherei alites KCT $\mathbf{1 7 4 4}$ om. KCT/ império] Aethereo E $\mathbf{1 7 4 5}$ post. scelera] bella pro nobis gerent $K C T \mathbf{1 7 4 6 - 8}$ om. KCT 1749 G. pers. CE Ge. pers. K Gedelias 
GEDELIAS - Seja misericordioso agora e afaste as desgraças com pena de nós.

JEREMIAS - Sois inimigos.

GEDELIAS - Ele considerar-nos-á amigos.

JEREMIAS - Bem,

evitai as más acções. Os vossos crimes contradizem-no

e a piedade banida do solo pátrio é um obstáculo.

Chamai-O de novo; que Ele venha. O Criador mostrar-se-á

um amigo indulgente. Quando nossos pais outrora

sentiram vergonha de seus crimes, foi Deus quem, espontaneamente,

destruiu com sua mão poderosa os acampamentos inimigos.

1740

Juncando de cadáveres as próprias tendas.

Quem, numa só noite, fez perecer soldados,

aos milhares, do exército do rei Senaqueribe? ${ }^{72}$

Fê-lo um só Anjo, às ordens de Deus.

Desviai-vos do crime; abraçai, de forma sincera,

a fé antiga. Combaterão a vosso favor,

sob as ordens de Deus, esquadrões de milícias celestes, voando com suas asas rápidas.

GEDELIAS - Cala-te, velho insensato, de espírito exaltado,

e poupa-me aos teus prodígios imaginários.

1750

Deixa o rei ocupar-se da guerra.

Tua mente senil apenas a ti cause cuidados.

JEREMias - Classificarás de fantasias tais prodígios?

É assim que, como mau neto, ilustras os feitos de teus avós?

Pois bem, deixo-te. Vai. Se tivésseis a sensatez da minha velhice

vós, generais do rei, e o próprio rei,

adorarieis Deus de forma mais sincera.

Floresceria então a paz na nossa pátria.

E se algum inimigo vos atacasse e vos movesse

Feroz guerra, sem demora o esmagariam

os velozes serviçais que cumprem as ordens de Deus.

Gedelias - Foge, foge daqui! Leva contigo teus funestos presságios.

Em tuas palavras não há paz nem salvação alguma.

JEREMIAS - Não te apoquentes: afasto-me, mas pensando dizer-te verdades mais amargas. Abandono quem já Deus abandonou.

Gedelias - Cruel destino o da pátria! Porque hás-de ter sempre

$\longleftarrow L$ / eras. Co.. ante corde $\mathbf{1 7 5 0}$ eras. iam ante me / me] iam $K$ / miraculis] fallaciis KCT 1753-4 om. KCT 1755 Age] Ego KCT / meae KC 1757 mente - Deum] arma posuissent manu KCT 1758 eras. Si........ ante Propensiore 1758-61 om. KCT 1762 G. pers. CE Ge. pers. KT Gedelias $L /$ omina] omnia $K \mathbf{1 7 6 3}$ Salus in ore laeta, nec pax est tuo $K C T \mathbf{1 7 6 4}$ dicturus tamen] quam primum Dei KCT $\mathbf{1 7 6 5}$ Saeueriora iussa dicturus tibi / Age, puer, linquo (eia add. T) quem linquit Deus add. KCT 1766 G. pers. CE Ge. pers. KT Gedelias $L$ 
Vates habebis corda qui pulsent metu?

Cur semper alto dira de caelo canent?

Quod Numen hoc est? Ecquid in uatem caput

1770 Ipse ominosum deligit? Semper truci

Duroque uultu faece de uulgi creat.

Ex rege natum si uirum saltem daret,

Aut stirpe clara nobilem adflaret senem,

Cum plebe tota crederent regni duces.

1775 Sed ante muros patriae lentus moror.

Signum canora bucina notum dabo.

Vigilantis aures regis accipient sonum.

\section{SAPHATIAS, muri Custos.}

REX. GOdolias, comitatus regius militaris

SAPH. Cuius sonorum bucinae murmur strepit

Hic ante muros? Noster an quisquam extera

1780 De gente cecinit? Cerno Gedeliam. Fores

Aperito, custos. Vnice o nostri comes

Laboris, ut te capio redeuntem libens.

Accede. Regem cerne uenientem foras.

Faustam peractae redde rationem uiae.

1785 Rex magne Solymae fidus en rediit tuus

Ille Gedelias.

GED. Genua curuata ad pedes

Dimitto, Solymae magne frenator, tuos.

Sacram reposco famulus hanc dextram, osculo

Libaret liceat.

R. Nota sed uirtus monet

1790 Vt liberalis praebeam amplexum tibi.

Quid agitat hostis? Arma num ferox parat

An se quieti tradit ac belli metu

Nos esse tutos lentus et deses sinit?

GED. Peragrata uelox cuncta lustraui loca,

1795 Quibus ipsa Babylon regnat ac urbem mihi

1768 Cur] Et KCT / canant KCT 1769 post est?] uatis ad munus caput KCT $\mathbf{1 7 7 0}$ Ipse deligit] Quid (Cur T) uile tetrici deligit KCT 1771 faece de uulgi] rusticam turbam $K C T$ 1772 uirum saltem] sacrum uatem KCT 1773 stirpe clara] genere claro $K C T$ / senem] uirum KCT $\mathbf{1 7 7 4}$ post. plebe] solyma CT solymi $K /$ regni] primi $K C T \mathbf{1 7 7 5}$ lentus moror] moror diu KCT $1777 \mathrm{Vt}$ regis aures incliti promptae audiant KCT $\mathbf{1 7 7 8}$ GOD. pers. KCT 1780 cecinit] 
profetas cruéis que põem os corações em sobressalto?

Porque anunciarão sempre novas terríveis vindas do céu?

Que divindade é esta? Escolherá ela para profetas

cabeças agoirentas? Fá-los sempre surgir

da ralé do povo, ameaçadores e severos.

Se apresentasse um varão, filho de reis,

ou inspirasse um nobre ancião, de estirpe ilustre,

os generais do reino e toda a plebe acreditariam nele.

Mas demoro-me em demasia diante das muralhas de minha pátria.

Vou dar o habitual sinal com a sonora trombeta.

O som chegará aos ouvidos atentos do rei.

\section{CENA IV: SAFATIAS, guarda das muralhas,} REI, Godolias e o séquito militar do rei

SAFATIAS - Que trombeta fere os ares com som tão estridente?

Foi algum dos nossos ou alguém de fora que fez soar a trombeta

diante das muralhas? Avisto Gedelias. Guarda,

abre as portas. Ó excelente companheiro de armas,

com que alegria te recebo de volta!

Aproxima-te, olha o rei que vem saindo.

Transmite-lhe o auspicioso relatório da tua viagem.

Excelso rei de Jerusalém, eis de volta o teu fiel servidor,

Gedelias.

Gedelias - Ajoelho-me a teus pés,

excelso soberano de Jerusalém.

Concede, peço-te, a este teu servidor, beijar

tua sagrada dextra.

REI - Mas a tua conhecida coragem

recomenda que te dê um caloroso abraço.

1790

Que planeia o inimigo? Prepara-se afincadamente para a guerra

ou dá-se ao descanso e, indiferente e desocupado,

permite-nos ficar tranquilos, sem receios duma guerra?

GEDElias - Percorrendo-os com rapidez examinei todos os locais

por onde se estende o domínio de Babilónia

« uenit KCT $\mathbf{1 7 8 1}$ eras. O comes ante Vnice / Vnice - comes] O comes nostri unice KCT $\mathbf{1 7 8 3}$ uenientem] gradientem $K C T \mathbf{1 7 8 5}$ en $m g$. CX $\mathbf{1 7 8 6}$ Ille] Ecce $K C T /$ GOD. pers. $L / \mathrm{ad}$ pedes] ad tuos $K \mathbf{1 7 8 7}$ tuos] pedes $K \mathbf{1 7 8 9}$ Nota sed] Clara tua $K C T \mathbf{1 7 9 0}$ liberalem $K C T$ $1792 \mathrm{ac}$ ] et $\mathbf{1 7 9 4}$ G. pers. E GOD. pers. L/ uelox] celeri KCTE / lustraui] sunt gressu KCT percurri $E \mathbf{1 7 9 5}$ ipsa] atra KCT / ac urbem] et nullum KCT 
Chaldaea nullam clausit adeunti plaga.

Nunc uisa fabor. Maius augendo nihil

Aut eleuando facere contendam minus.

Nabucdonossor asper ut bellum audiit

1800 Placere Solymis, percitus flamma sui

Rapida furoris, summa tectorum petens,

Iussit sonorem concauo cornu dari,

Turbata Babylon tota quo cantu fuit.

Venere mixti principes turbae uiri,

1805 Et, conglobati regis imperium sui

Accipere prompti, regiae impluuium domus

Amplum tenebant. Ipse marmorea ferox

Tandem e fenestra cepit aspectu loqui

Truculentiore. Dixit Isacidum genus

1810 Abolere penitus esse decretum sibi.

R. Prohibete, Superi, hoc reddite Tyranno malum.

GED. Arma imperauit rapta celerarent duces.

R. At ipsa Babylon, pace quae floret diu,

Bellum parare iussa, quo uultu tulit?

1815 GED. Vt fama uastam didita per urbem uago

Rumore plebem mouit, et gliscens magis

Magisque uario pectora impleuit metu,

Motuque belli intonuit armorum fragor,

Passimque mixta tympano horrebat tuba.

1820 Virente lauri ut fronde compositae pyrae

Vbi faculis arsere subiectis, crepant

Flammaque strident personantes, haud secus

Vrbs ampla trepidabat tumultu bellico.

R. Audite, ciues: omnis in ferro est salus.

1825 GED. Iam legio passim lecta frenatis equis

Coibat, omni se cateruatim die

Addebat equitibus eques, et galea nitens

Hastamque uibrans castra cumulabat pedes.

Quin ipse belli cupidus ardentem ducem

1830 Nabucdonossor inter armatos gerit.

R. En flamma ciues asperi belli micat,

[p. 64]

Vt tecta Solymae clara comburat meae.

1796 nullam] regio $K C T$ / plaga] oppidum KCT 1797 uisa] uera KCT 1798 Aut] Neque KCT 1799 asper] om. K $\mathbf{1 8 0 0}$ Placere Solymis] Renuntiari CT Renuntiantem K / sui] graui KCT 1801 Rapida] Irae et KCT 1803 om. KCT 1806 regiae - domus] regio stabant foro KCT / eras. staba ante regio $K \mathbf{1 8 0 7}$ om. KCT 1808 Tandem fenestra toruus ex alta loqui KCT / Incepit ore flammeo, et crebra micans $a d d$. KCT 1809 Trux in fauilla gentis hebraeae genus 
e não deixei de entrar em nenhuma cidade do litoral caldeu.

Falar-vos-ei agora do que vi. Tentarei

nada ampliar com exageros, nem diminuir com omissões.

Quando o severo Nabucodonosor ouviu dizer que a guerra

era do agrado de Jerusalém, em súbito acesso de cólera

1800

dirigiu-se à parte mais elevada do palácio

e ordenou que fizessem ressoar as côncavas trombetas,

com um som que fez estremecer Babilónia inteira.

Acorreram as mais ilustres personalidades, de mistura com o povo,

e todos juntos, prontos a acolher as ordens de seu rei,

1805

ocuparam o vasto pátio do palácio real.

De semblante muito tenso,

falou finalmente da sua janela de mármore:

disse estar decidido a exterminar, duma vez por todas,

a descendência dos filhos de Isaac.

REI - Deuses do alto, não consintais e fazei recair tal desgraça sobre o tirano.

GEDELIAS - Ordenou aos generais que se apressassem a pegar em armas

REI - Mas a própria Babilónia, que tanto tempo prosperou na paz, obrigada a preparar-se para a guerra, de que forma encarou isso?

GEDELIAS - Mal a fama posta a correr pela vasta cidade ${ }^{73}$

agitou o povo com vagos rumores e, insinuando-se mais e mais, sobressaltou os espíritos com medos vários,

com as movimentações bélicas, ressoou o fragor das armas e por

todo o lado se fez ouvir o som medonho de trombetas e tambores.

Tal como as piras erguidas com folhas verdes de loureiro,

1820

Depois de ateadas por tochas, crepitam

e, enquanto ardem, emitem sons estridentes,

assim fervilhava a grande cidade em agitação bélica. ${ }^{74}$

REI - Escutai, cidadãos, toda a salvação está nas armas. ${ }^{75}$

GEDELIAS - Já em todo o lado se reuniam tropas de elite,

com cavalos aparelhados; todos os dias, em grupos,

a cavalaria juntava-se e, de capacete reluzente,

a infantaria, brandindo lanças, enchia os acampamentos.

Mais: sedento de guerra, o próprio Nabucodonosor

surge fardado de general, rodeado de soldados, cheio de entusiasmo.

1830

REI - Já cintila a chama da cruel guerra, cidadãos,

para queimar os nobres palácios da minha Jerusalém.

$\longleftarrow$ KCT 1810 penitus] dixit $K C T \mathbf{1 8 1 1}$ hoc] id $K C T \quad \mathbf{1 8 1 3 - 1 4}$ om. $K C T \quad \mathbf{1 8 1 5}$ dedita $K L$ 1819 tympano] classico $K C T \mathbf{1 8 2 0}$ om. ut $K \mathbf{1 8 2 1}$ eras. fa....s ante arsere / faculis $m g$. / Vbi conflagrantes igne subiecto aestuant KCT $\mathbf{1 8 2 2}$ Flamma sonante concrepant, haud secus $K C T \mathbf{1 8 2 4}$ Omnis] Igitur $K C T \mathbf{1 8 2 5}$ legio] turma $C T$ turba $K \mathbf{1 8 2 8}$ cumulabat] complebat $K C T$ comulabat $L \mathbf{1 8 3 0}$ gerit] agit KCT $\mathbf{1 8 3 1}$ emicat KCT 1832 post clara] prosternat solo KCT 
Timere nolo. Reputo uiolentam tamen

Fortunam et hostem. Namque si firma occidunt,

1835 Inualida quonam tuta reddentur modo

Potentiorum quassa praesertim manu?

GOD. Timor aliorum forte tolerari potest.

In rege crimen turpe. Nam quantum supra

Reliquos in altum regium surgit decus,

1840 Virtute tantum debet insigni suis

Praeire ducibus. Esto Babylonem scias

Exercitu uenire quam lectissimo.

Ideone manibus arma de nostris cadent,

Prius relicta quam quid in pugnam ferat

1845 Hostis probemus? Ergo non hostis modo

Sed fama nostrum rapiet in cladem genus?

R. Si solus animi posset indomiti uigor

Arcere longe finibus inimicum meis

Aut sustinere pondus armorum graue,

1850 Haec dextra regnum sola defensum daret.

SAPH. Virtus iniquam saepe fortunam regit.

Et saepe uirtus uicta fortunae cadit.

Raro sinistro pugnat euentu inclita

Quem fortitudo munit.

R. Hoc rarum tamen

1855 Ne casus in me uereor infelix probet.

GED. Meliora sperans cogita. Sortem Deo

Belli annuente prosperam laetus cape.

Non arma desunt. Ducibus inuictum tuis

Est robur animi. Cerne pro patria et focis,

1860 Pro liberis, coniugibus et Deum sacris,

Ex urbis huius moenibus pulcherrimae

Tibi proeliandum. Copiae hostiles loco

Iniquiore duriora perferent.

Calore solis feruido urentur die,

1865 Nocte patientur algidi roris gelu.

Hostemque multo grauior urgebit fames

Nos obsidendo Marte quam saeuo premet.

1833 nolo] possum KCT / uiolentae impetum KCT $\mathbf{1 8 3 4}$ Fortunae KCT $\mathbf{1 8 3 6}$ Potentiore KCT 1839 regium surgit] regis assurgit KCT $\mathbf{1 8 4 0}$ post debet ] heroa $C T$ heroas $K$ 1841 scias] audias $K C T \mathbf{1 8 4 2}$ Exercitum $K$ / selectissimo $C T$ selectissimum $K$ / eras. ideone post selectissimo C $\mathbf{1 8 4 3}$ de nostris] faemineis KCT $\mathbf{1 8 4 4}$ relicta] remissa $K C T \mathbf{1 8 4 6}$ fama] flamma $K \mathbf{1 8 4 7}$ indomiti] inuicti $K C T \mathbf{1 8 4 8}$ om. $K C T \mathbf{1 8 4 9}$ Aut] Bene $K C T \mathbf{1 8 5 0}$ Haec - sola] Haec sola regnum dextra KCT 1851 saepe] clara KCT 1852 uicta ] clara KCT / cedit 
Não quero ter medo. Contudo, considero cruéis

a fortuna e o inimigo. Porque se o que está firme se desmorona, de que modo se tornará seguro o que é débil, 1835 sobretudo se for abalado pela força dos mais poderosos?

Godolias - Nos outros poderá, eventualmente, tolerar-se o receio, mas num rei é crime vergonhoso. Na mesma medida

em que o prestígio dum rei se eleva acima dos demais, nessa mesma medida deverá ele, com insigne coragem, 1840 ir na frente de seus generais. Fica sabendo então:

Babilónia aproxima-se com o seu melhor exército.

Havemos, por isso, de deixar cair as armas de nossas mãos

sem antes verificarmos o que traz para a batalha

o inimigo? Será então não apenas o inimigo

1845

mas também a fama a precipitar na ruína o nosso povo?

REI - Se apenas com o vigor de minha indómita vontade

me fosse possível manter o inimigo afastado do meu território, ou suster a forte pressão dos seus exércitos,

a minha dextra, só ela, garantiria a defesa do reino.

1850

SAFATIAs - A coragem, muitas vezes, domina a fortuna adversa.

REI - E outras vezes é a coragem que cede, vencida, perante a fortuna.

Godolias - Raramente é mal sucedido em combate quem está possuído de nobre coragem.

REI - Mas receio que, por infeliz acaso, me aconteça a mim o que é raro acontecer.

Godolias - Pensa confiante em melhores coisas. Com Deus do teu lado, agarra confiante a sorte favorável da guerra.

Armas não faltam; teus generais são pessoas

de indomável resistência. Olha, é pela pátria e seus lares,

pelos seus filhos, pelos seus cônjuges e pelos sagrados rituais,

1860

que, do alto das muralhas desta esplendorosa cidade,

deverás combater. As forças inimigas,

em posição mais desvantajosa, atravessarão transes bem duros.

De dia, serão abrasadas por tórrido calor do sol,

de noite suportarão o frio intenso da gélida geada.

1865

A fome atormentará mais duramente o inimigo

durante o cerco do que ele nos oprimirá a nós, com a cruel guerra.

$\longleftarrow$ L $\mathbf{1 8 5 4}$ rarum] rerum $K C T /$ tamen] probet $K C T \mathbf{1 8 5 5}$ post me] saluus infausto tremo KCT 1856 Godolias pers. $L /$ sperans] princeps $K C T \mathbf{1 8 5 7}$ laetus] haud tristis KCT 1859 et ] om. $K C$ ac $T \mathbf{1 8 6 1}$ Ex] Et $K /$ huius] altae $K C T /$ pulcherrimis $K C T \mathbf{1 8 6 3}$ Iniquiore proelii casum ferent KCT 1864 solis feruido] tepidi solis KCT $\mathbf{1 8 6 5}$ algidi E1; algida E / algida KCT 1866 Hostemque multo] Noctemque mulco $L /$ Quin grauius hostem dura lacerabit fames KCT 1867 Nos] Non $K$ 
Namque unde tantis copiis cibos petent?

Quae fama nostrae gentis et laudis tuae

1870 Peragrabit orbem, si repugnando retro

Aciem redire barbaram coegeris?

Auxilia quae sint nostra tu primus uides.

Finitima ualidis regna nos armis iuuant.

Opem quadrigas frenat in nostram Pharus.

1875 Regione currus mille de Nilotica

Sociale bellum gente pro nostra fremunt.

Quis haec habeat et trepidet? Imbellem puto.

R. Verum fatebor. Vna religio mihi

Suspecta reddit arma. Nam uates atrox

1880 Numquam recedit a memoria. Instat die,

Agitatque maestae noctis in silentio,

Et larua tamquam dira terrorem incutit.

Narrare uisus semper aduersi Dei

Supplicia grauia meque deberi hostico

1885 Pecudem macello, patrium flammis solum.

GOD. Mea si probasses consilia quae olim dedi,

Iam larua mentem nulla terreret tuam.

R. Et quae relicta quereris?

GOD. Audacter loquar.

Erat, erat ille caede mactandus senex.

1890 Ita lingua mendax auguris coercita

Falsos tibi uulgare cessasset metus.

R. A caede abhorret animus at tali meus.

GOD. Pietas inepta saepe fit crudelitas.

R. Cui nempe?

GOD. Regi, qui nimis parcit suis.

1895 GED. Quod ille regem cruciet, hoc habet piae

Sinceritatis praemium. Tandem cadat

Magicae peritus artis et fato suo

Te, nos, auitam liberet terram metu.

R. Eius peremptae quis rogos Furiae feret?

1900 PH. Ego. His ademptus, si iubes, manibus cadat.

In auferendo noxio et laeuo augure,

$\mathbf{1 8 6 8}$ cibum $K C T$ / petet $K T \mathbf{1 8 6 9}$ gentes $L$ / Quae laus hebraeae gentis et famae tuae $K C T$ $\mathbf{1 8 7 0}$ si] sic $K$ / retro] feram $K C T \mathbf{1 8 7 1}$ Pepuleris aciem barbari Assyrii retro $K C T \mathbf{1 8 7 2}$ uide $K C T \mathbf{1 8 7 6}$ premunt $L \quad \mathbf{1 8 7 7}$ imbellem] ignauum $K C T \mathbf{1 8 7 9}$ atrox] ferox $K C T \mathbf{1 8 8 1}$ Agitatque moestae] Instatque tristi $K C T \mathbf{1 8 8 2}$ larua - dira] dira ueluti larua $K C T \mathbf{1 8 8 3}$ semper uisus $K C T$ / aduersi] aeterni $K C T \mathbf{1 8 8 4}$ grauia] graui $K \mathbf{1 8 8 5}$ Clamat macello bruta ceu pecus forem $K C T$ 1886 consilia] dicta $K /$ quae - dedi] princeps semel $K C T \mathbf{1 8 8 7}$ Iam - nulla] Iam nulla mentem 
Onde irão eles procurar mantimentos para tantos soldados?

Que fama da nossa nação e de teus méritos

percorrerá o mundo se tu, oferecendo resistência,

forçares o exército inimigo a bater em retirada?

És tu o primeiro a ver os apoios com que contamos.

Os reinos limítrofes ajudam-nos com fortes exércitos;

o Egipto apresta as suas quadrigas para vir em nosso auxílio.

Inúmeros carros vindos das zonas do Nilo

1875

clamam ruidosamente por guerra em aliança com o nosso povo.

Quem, na posse de tudo isto, ainda vacilará? Só um cobarde, a meu ver.

REI - Confessarei a verdade. Apenas uma questão de escrúpulo

me põe renitente em relação à guerra. As ameaças do profeta

não me saem da lembrança. Perseguem-me durante o dia,

e não me deixam sossegar, em noites de silêncio e aflição.

Ele aterroriza-me como se fosse um fantasma cruel,

surgindo-me sempre a narrar castigos terríveis de Deus

que nos é hostil, dizendo-me destinado a ser entregue ao inimigo,

como gado para o matadouro, e que o solo pátrio será pasto das chamas.

1885

Godolias - Tivesses seguido os conselhos que em tempos te dei,

e já nenhum fantasma aterrorizaria tua mente.

REI - E de que te queixas mais?

Godolias - Di-lo-ei corajosamente.

Devias ter punido esse velho com a morte.

Aquela língua mentirosa de adivinho, silenciada dessa forma,

1890

teria deixado de te incutir falsos receios.

REI - Mas mortes violentas como essa repugnam ao meu espírito.

GoDolias - Compaixões inoportunas redundam muitas vezes em crueldade.

REI - Contra quem?

Godolias - Contra o rei, demasiado indulgente com os seus.

GEDELIAS - Por atormentar o rei, recebe por recompensa

uma lealdade sincera. Que morra, duma vez por todas,

esse perito em artes mágicas, e que com sua morte te livre do medo

a ti, a nós e à terra de nossos antepassados.

REI - Quem suportará as tochas da morte desta Fúria?

FAsSURO - Eu. Basta ordenares e ele cairá morto às minhas mãos.

1900

Se for crime matar um nocivo e funesto adivinho,

$\longleftarrow$ larua $K C T \mathbf{1 8 8 8}$ eras.

ante quereris / GED. pers. CT / loquar] querar KCT $\mathbf{1 8 8 9}$ caede $m g$. C 1890 Ita auguris coercita loquacissimi $K C T \mathbf{1 8 9 1}$ Vulgare falsos lingua cessasset metus $K C T 1892$ A caede prorsus animus abhorret meus KCT 1894 PH. pers. KC / parcet $E$ 1895 Go. pers. $K /$ Ille, ille quod te cruciat, hoc habes piae $K C T \mathbf{1 8 9 6}$ tandem] semel $K C T$ 1898 auitam] penates $K C T$ / terram] tanto KCT 1899 feret furiae rogos? KCT $\mathbf{1 9 0 0}$ ademptus] perempta $K C T$ 
Si culpa fuerit, poena me quaerat reum.

R. Cur tempus armis utile parandis tero?

Parcite senectae languidae unius uiri.

1905 Si dura belli flamma iam muros prope

Fulgore lato incendium spargens micat,

Restinguere properate quam celerrimi.

Ego primus inter grauia discurram comes

Pericla uester. Nec trucem uatem moror.

1910 Pectus alio repente conuertit Deus.

PH. Ductoris ageris spiritu magni inclito.

Sic est eundum. Regium edictum placet.

Fauete, ciues. Auguris uani minas

Contempsit altae sceptrifer Solymae. Bene

1915 Bene ominemur; nostra sit uictoria.

R. Celeste testor Numen et auorum sacra,

Quibus ara fumans igne turicremo calet:

Amore patriae bella seruandae gero.

Si fausta fuerint, inde libertas meis

1920 Bene parta regnis prospere Isacidas alet.

Si laeua, capitis poena sit solum mei

Alioque Solyma uiuat incolumis duce.

GOD. Rex, uiue. Vultu laeta promittis tuo.

Quod instat, hoc est utile. Excubiae petant

1925 Inimica celeres castra. Sociorum uoca

Auxilia, Pharii regis accerse alites

Currus et equites; coge peditatum cito.

R. Agantur ista, fide Godolia. Duos

Mihi trade prompto milites animo. Volent

1930 In castra, lustrent omnia, et certa afferant.

GOD. Adeste bini quos mihi notos scio

Virtute belli. Rex uocat. Promptus habes.

Hi certa ab ipsis hostium castris ferent.

R. Ad Martis opera dura truculenti sati

1935 Generosa uirtus ore se prodit. Sat est.

Occulti abite, petite uenientem agmine

Rapto Tyrannum. Quas ferat gentes, quibus

In bella ueniat copiis, addiscite.

1902 reum] Deum $K \mathbf{1 9 0 7}$ celerrime $K C T \mathbf{1 9 1 1}$ Ductoris ageris] Inuicte regis $K C T \mathbf{1 9 1 2}$ Ageris ab ore regium dictum excidit KCT 1913 uani] stulti KCT 1914 eras. Soly ante Sceptrifer / sceptriger KCT 1916 sacra] Deos KCT 1919 fuerint] dederint KCT 1921 Si laeua, cineres patriae inuoluant meos KCT 1922 Ipsaque regni mole pereuntis tegar KCT 1923 G. pers. E 
que o castigo me atinja a mim, que sou o culpado.

REI - Porque gasto tempo precioso para a preparação de meus exércitos? Poupai a debilitada velhice dum simples homem.

Se a chama cruel da guerra já cintila junto às muralhas,

fazendo alastrar incêndios de grandes labaredas,

apressai-vos sem demora a apagá-los.

Serei o primeiro a enfrentar os maiores perigos,

a vosso lado, e nem vou perder mais tempo com o irascível profeta.

Deus alterou repentinamente a minha disposição de espírito.

FAssuro - Transportam-te nobres sentimentos, próprios dum grande chefe.

É assim que se deverá avançar. A decisão do rei é do nosso agrado.

Aplaudi, cidadãos. Desprezou as ameaças do falso adivinho

aquele que empunha o ceptro sobre a gloriosa Jerusalém.

Pronunciemos palavras de bom augúrio. A vitória será nossa.

1915

REI - Invoco por testemunhas o Deus do céu e a religião de meus avós, em honra de quem ardem altares que fumegam com incenso queimado: é por amor à Pátria, confiada à minha guarda, que faço a guerra.

Se esta nos for favorável, a liberdade daí advinda

para os meus reinos trará prosperidade aos filhos de Isaac.

1920

Se nos for desfavorável, seja só eu a receber o castigo

e Jerusalém subsista incólume com outro chefe.

Godolias - Vive, ó rei. O teu aspecto promete façanhas auspiciosas.

É importante o que está prestes a acontecer. Enviem rapidamente

sentinelas aos acampamentos inimigos. Convoca

os reforços aliados do rei do Egipto. Faz chegar os carros

e os velozes cavaleiros. Reúne de imediato a infantaria.

REI - Façam isso. Fiel Godolias, faz-me chegar

dois soldados corajosos, que vão rapidamente aos acampamentos, para tudo examinarem e voltarem depois com notícias seguras.

1930

Godolias - Vinde cá, vós dois, que eu bem conheço

pela vossa coragem na guerra. O rei chama-vos. Ei-los prontos.

Eles trazer-te-ão informações seguras dos acampamentos inimigos.

REI - Para os duros trabalhos de Marte, ${ }^{76}$ a nobre coragem

Mostra-se com rosto de filho truculento. Basta-me.

Saí disfarçados, ide até junto do tirano que se dirige para cá

à frente de seus exércitos. Que povos traz ele consigo?

Com que efectivos vem para a guerra? Investigai.

« Gedelias pers. $L$ / Rex uiue] Euge, euge KCT 1924 utile] maximum KCT 1925 celeres] tacitae KCT 1927 coge - cito] coeat accitus pedes KCT 1928 ista] omnia KCTE 1929 euolent KCT 1932 Promptus habes] promptos cape KCT 1933 ab hoste nuntia inspecto ferent $K C T$ $\mathbf{1 9 3 5}$ ore - est] ore se uestro indicat KCT 
M. Ibimus ad ipsa castra festino gradu.

1940 Qualis sagitta stridulo praeteruolat

Emissa neruo, qualis aut caelo micans

Breuem corusco stella describit uiam.

Hieremias. Miles Explorator. Pver Hieremiae. Rex. Dvces

H. Breuius quid hostis acer in castris agat,

Docere possum. Sistite emissi gradum.

1945 Abite retro. Discite audaces Deo

Parere. Si quis extat in uobis pius

Sese cohibeat. Si impius, uadat uiam.

M. Annose, te quis ore terrentem feret?

Solymae colendae sceptrifer uates adest.

1950 P. Cernis tumere regium uultum pater?

H. Age, puer, annis disce sub primis mea

Auctoritate spernere superbos. Cole

Deum colentes. Sperne spernentes Deum.

R. Meumne uecors ante conspectum redis?

1955 Abire iussus unde non possem tui

Videre rictus oris. O crudelior

Tigre et leone, cuius e latebris fera

Montana siluae dentibus mordax uenis?

Aestu calente uipera minacior,

1960 Letale uirus euomet nocentior.

Arcete, mando, Regis a uultu procul.

GOD. Temerarie senex siste furialem gradum.

Sine te quieti blanda pax regni uiget.

Per te, procella uasta de caelo ruit

1965 Abigitque diro turbine serenum diem.

H. Tua criminando scelera ne facias mea.

A bello et armis quis recedendum monet?

Quis arma clamat esse capienda? Hic taces?

Effare? Pacem ego oro, tu bellum cupis.

1970 Cur me quietae pacis inimicum uocas?

1936 Occulti abite] abite taciti KCT 1937 Rapto tyrannum] Hostem citato $K C T \mathbf{1 9 3 8}$ In] Ad $K C T 1939$ ipsa] hostis $K C T \mathbf{1 9 4 1}$ Emissa] Excussa $K C T \mathbf{1 9 4 3}$ scae. non ind. KC / acer hostis KCT 1944 emissi] superbi KCT 1945 Abite retro] Redite propere KCT $\mathbf{1 9 4 7}$ uadat uiam] caepta exigat KCT 1948 Annosa quis te furia clamantem feret KCT 1949 O magne Solymae rector hunc tandem aspicis KCT 1950 regium uultum] regiam faciem KCT / Iram aestuantis principis obortam caue add. KC [trad. "Tem cuidado com a cólera que sai dum príncipe exaltado"] 
Soldados - Dirigir-nos-emos a esses acampamentos sem perda

de tempo, como setas velozes que se escapam despedidas

1940

pela corda estridente do arco, ou como estrelas cadentes

que riscam o céu estrelado em seu breve curso. ${ }^{77}$

CEnA V: Jeremias, Soldados Exploradores, Moço, Rei, Comandantes. ${ }^{78}$

JEREMIAS - Sobre o que faz o feroz inimigo em seus acampamentos

posso informar-te em pouco tempo. Detende-vos, emissários;

voltai para trás. Aprendei a obedecer corajosamente a Deus

1945

Se existe entre vós alguém com sentimentos piedosos,

que se contenha; se for ímpio, que saia.

SOLDADO - Quem te suportará, velhote, com esse ar aterrador?

Ó venerável soberano de Jerusalém, o profeta encontra-se aqui.

Moço - Meu pai, vês o semblante do rei tomado de cólera?

1950

Jeremias - Vamos, rapaz, aprende desde pequeno,

com o meu exemplo, a desprezar os soberbos.

Honra os que honram Deus e despreza os que O desprezam.

REI - Insensato! Voltas de novo à minha presença?

Para onde me hei-de retirar a fim de não ver

1955

os esgares de teu rosto? Hás-de ser mais cruel

que um tigre ou um leão? ${ }^{79}$ De que antros da floresta

acabas de sair, fera das montanhas, de dentes afiados?

Mais ameaçador do que uma víbora incendiada pelo calor,

ele vomitará perigosamente sua mortífera peçonha.

1960

Ordeno-vos que o afasteis para longe da vista do rei.

Godolias - Suspende teus passos tresloucados, velho insensato.

Sem ti, o reino goza tranquilamente duma paz benéfica;

contigo, desabam do céu terríveis tempestades

e os dias serenos desaparecem no meio de ventos ciclónicos.

1965

JEREMIAS - Não me atribuas teus crimes, incriminando-me.

Quem recomenda o afastamento da guerra e das armas?

Quem proclama que se deve pegar em armas? Calas-te agora?

Fala. Eu prego a paz, enquanto tu desejas a guerra.

Porque me chamas então inimigo do sossego e da paz?

1970

« 1955 possem] possum $T \mathbf{1 9 5 7}$ Tigre et] Tigride $K /$ e] a $K C T \mathbf{1 9 5 8}$ dentibus mordax] tabido morsu KCT 1959 Aestu calente uipera] Solitoque lingua uiperae $K C T \mathbf{1 9 6 0}$ Fit proppior, ut nocentior tabem uomat KCT 1961 mando] famuli $K C T \mathbf{1 9 6 2}$ G. pers. $K$ / gradum] impetum KCT 1964 de caelo] bellorum KCT 1965 diem] otium KCT 1966 ne] cur $C T$ quid $K /$ facis KCT 1967 A bello et] Penitus ab KCT 1969 pacem - oro] pacem cupio KCT 1970 Cur] Et eras. Cur s. $u$. Et $K C T$ 
Turbator unus patriam in cladem trahis.

Per me procellas iam represisset Deus,

Nisi tu uolenti prorsus obstares Deo.

GOD. Loquax senecta, talia quis audit neque

1975 Te?

R. Quando pones pectoris rabiem tui

Sanoque mentem corde tranquillam geres?

Totiensne furiis blandus ardentem feram

Suaque canentem somnia? A caelo nouos

Affers tumultus scilicet? Quid ais? Age.

1980 H. Dum frena laxas pronus iracundiae

Animumque nimbo pateris irarum rapi,

Nec tu salutis respicis scopum tuae

Nec ipse iussa interpres expono Dei.

Pacatus audi, pectoris compos tui:

1985 Ego iussa peragam Numinis, compos mei.

GED. Audire uatis dicta simulati fuge.

Sub fraudulenta mille canitie latent

Artes nocendi.

H. Nempe ne pateant tuae,

Et uera cernat audiens regem uetas.

1990 GED. Quae uera?

H. Verus quae mihi ostendit Deus.

R. O astra noctis lumina sereni et poli,

O terra questus patria quo uertam meos?

H. Omitte terram et astra, militiam poli.

Animo relinque crimen antiquum. Dei

1995 Testare sanctum Numen et nomen time.

R. Quonam usque tandem?

PH. Lenta si tibi est manus

Laruam in furentem, lingua si tardo stupet

Retenta freno, uel supercilio annue:

Vmero ab utroque demetam ferro caput.

2000 H. Age, fortis esto; caede languentem senem.

Facti trophaeum tolle magnificum tibi.

PH. Sine moriatur.

P. Ne meum occidas patrem.

1973 prorsus] occurrere KCT 1974 G. pers. E $\mathbf{1 9 7 5}$ tui] efferi KCT $\mathbf{1 9 7 7}$ blandus] rursus KCT $\mathbf{1 9 7 8}$ Suaque canentem] Vana repetentem KCT $\mathbf{1 9 7 9}$ Motus potentis forsan asportas Dei KCT 1980 laxas pronus] laxa soluis KCT 1983 iussa interpres expono] monitis fungor aeterni $K C T \mathbf{1 9 8 4}$ pectoris] lenis et KCT $\mathbf{1 9 8 5}$ peragam Numinis] domini proferam $C T$ domini conferam $K \mathbf{1 9 8 6}$ Go. $K$ / uatis] magici $K C T \mathbf{1 9 8 9}$ Et] Ne $K C T$ / audiens] simplicem $K C T$ 
O único agitador és tu, que arrastas a pátria para a ruína;

por meu intermédio, já Deus teria feito recuar as tempestades

se não te opusesses intransigente à vontade divina.

Godolias - Velhice palradora, quem, senão tu,

ouve tais coisas?

1975

REI - Quando abandonarás essa fúria do teu coração,

e te comportarás serenamente, com razoabilidade?

Hei-de suportar-te com paciência tantas vezes ardendo em fúria

e proclamando as tuas fantasias? Que novos tumultos

anuncias, então, vindos do alto. Que tens a dizer? Vá!

JEREMIAs - Enquanto te deixas levar pela ira

1980

e permites que teu espírito se arrebate em torvelinhos de cólera,

nem tu consegues manter o teu equilíbrio,

nem eu, como profeta de Deus, exponho as suas ordens.

Ouve com calma, em teu juízo, o que eu,

em meu juízo, anunciarei como ordens de Deus.

1985

GEDELIAs - Evita escutar as palavras desse falso profeta.

Sob essas cãs enganadoras ocultam-se mil

artimanhas perigosas.

JEREMIAS - Só para que tuas artimanhas não fiquem a descoberto,

e ele, ao escutar-me, descubra a verdade, impedes o rei de me ouvir.

GeDElias - Que verdade?

JEREmias - A que o verdadeiro Deus me revela.

1990

REI - Ó astros, luzeiros da noite e do céu sereno,

ó terra pátria, para onde virarei meus lamentos?

JEREMias - Deixa em paz a terra e os astros, milícia do céu.

Desiste de teus crimes antigos.

Proclama o sagrado poder de Deus e teme o seu nome.

1995

REI - Mas com que fim, afinal?

Moço - Se tua mão se mostra frouxa

com este fantasma delirante, se tua língua fica paralisada,

presa num bloqueio persistente, faz-me sinal com o sobrolho, e eu,

com minha espada, arrancar-lhe-ei a cabeça de cima dos ombros.

JEREMias - Vá, sê corajoso; mata um velho inválido.

Ergue o magnífico troféu do teu feito.

Moço - Deixa que o matemos.

Moço - Não mates o meu pai.

1990 Go. pers. KCT / Verus] Caelo KCT 1991 noctis] nostis $K$ / et om. K 1992 eras. patria ante questus K 1995 Testare] Precare KCT/ et nomen] hoc solum KCT 1998 uel] da KCT/ annue] notam KCT 1999 demetam ferro] uile eiiciam KCT $\mathbf{2 0 0 1}$ Facti] Fasti $L$ / tibi] incliti $K C T$ 
R. Siste. Miseresco, cuius est odio mihi Acerba lingua, uita non est tam grauis.

2005 GOD. O saeua misericordia! Inimico seni

Poenam remittis?

R. Tempore occumbet suo.

H. Haec uita minimi fit mihi. Vanas minas

Et hos furores neglego. Sperno uiros

Adeo profanos. Gloriae et laudis meae

2010 Pars magna fuerit talium dextra ultimum

Clausisse uitae tam fatigatae diem.

His gloriosum manibus est mortem pati.

Necat innocentem nemo, si non est nocens.

R. Tua quod furenti uita displiceat tibi

2015 Mortique dedas te uelut mutum pecus,

Onerare debes principes coram probris?

Cur me audiente ducibus insultas meis?

Regisne terere uerticem quaeris pede?

Adeste, ciues, colla flectamus; premet

2020 Pedibus sacratis magnus interpres Dei.

H. O sceptra regni lubrica! Vt pauci sedent

In arce regni qui Dei iussis uelint

Obtemperare?

R. Non tibi, at uolo Deo.

H. Simulata dicis. Mentis abstrusa intimae

2025 Secreta uideo; nec mihi, nec uis Deo

Parere. Viuit contumax proteruia

Inclusa pectoribus sacrilegis. Restitas

Animosque supra sortis humanae uicem

Regnique tollis. Tollere at cito desines,

2030 Te deprimente, premere qui elatos potest.

R. Abscede iubeo. Vade, ne Solymam redi.

H. Discedo, iussa pauca sed fabor Dei.

Praeter sacrilegia, stupra uulgato omnium

Pudore regnant; uxor incestat uiri

2035 Polluta lectum; uir datam frangit fidem

Miserae maritae; pellicis amatae in domo

Contaminata noctis et diei accola,

$\mathbf{2 0 0 4}$ non est tam] cur fiat C cur fiet KT $\mathbf{2 0 0 5}$ inimico] indigno KCT $\mathbf{2 0 0 7}$ Haec] Mea KCT $\mathbf{2 0 0 8}$ Et hos furores sperno neque metuo uiros KCT 2009 Adeo profanos] Ego tam scelestos $K C T 2011$ Clausisse secli tam procellosi diem KCT 2012 Ab his nequit nisi innocens mortem pati KCT 2013 om. KCT $\mathbf{2 0 1 4}$ displiceat] sordescat KCT $\mathbf{2 0 1 5}$ te] ne KC $\mathbf{2 0 1 6}$ Lacerare debes 
REI - Sossega. Tenho compaixão de quem me é odioso pela ousadia de sua língua, mas sua vida não me é tão desagradável.

Godolias - Oh! Cruel misericórdia! Um velho que te é hostil

e desistes de o castigar?

REI - A seu tempo ele morrerá.

JEREMIAs - Esta vida pouco conta para mim, e a ameaças vãs

e a fúrias destas não ligo: tal é o meu desprezo

por homens ímpios. Grande glória e louvor

seria para mim acabar o último dia

2010

duma vida tão atribulada às mãos de tal gente.

É glorioso sofrer a morte sob tais mãos.

Ninguém mata um inocente se este não é nocivo.

REI - É por andares irritado e descontente com a vida

e te expores à morte como um animal mudo

2015

que deves humilhar os príncipes, injuriando-os em público?

Porque insultas os meus generais à minha frente?

Queres esmagar a cabeça do rei com os teus pés?

Vinde cá, cidadãos, dobremos os nossos pescoços;

o grande profeta de Deus pisá-los-á com seus sagrados pés.

2020

JEREMIAs - Ó ceptros enganadores do poder! Como são poucos

os que se instalam no auge do poder dispostos a conformar-se com os preceitos de Deus.

REI - Não é a ti, mas a Deus que quero obedecer.

JEREMias - Falas simuladamente. Secretos desígnios ocultam-se

em teus pensamentos. Estou vendo. Nem a mim nem a Deus

2025

queres obedecer. Obstinada petulância vive encerrada

nesse peito sacrílego. Resistes e estendes tua audácia

para além do que é tolerável pela sorte da condição humana

e do poder. Mas bem depressa deixarás que te levante o ânimo,

quando te sentires em baixo, Aquele que pode oprimir os orgulhosos.

2030

REI - Afasta-te daqui. Vai, e não regresses a Jerusalém.

JEREMIAS - Retiro-me, mas direi o pouco que Deus me ordena que diga.

Além de sacrilégios, reinam atentados ao pudor, sendo pública

a desonra de toda a gente. A esposa conspurcada

avilta o leito do marido. O marido quebra a fidelidade

2035

devida à infeliz esposa. Passa dias e noites

frequentando antros de prostitutas.

« regiam famam probris KCT 2019 premet] teret KCT $\mathbf{2 0 2 0}$ magnus] diuus KCT 2021 pers. REX $L \quad 2022$ Regali in arce, qui uelint iussis Dei $K C \mathbf{2 0 2 3}$ At] om. KCT 2026 proteruial superbia KCT 2031 post. iubeo] pestilens regni lues KCT 2032 Abscedo, quaedam iussa sed peragam Dei KCT / eras. sed ante quaedam $K \mathbf{2 0 3 7}$ diei accola] die incola $K C T$ 
Peregrinus autem et liberis hospes suis.

Soceri libido uitiat oppressam nurum.

2040 Frater sororem, flagitat fratrem soror.

Exhorruistis? Ista pars scelerum minor.

Caedem patrantes quo magistratu luunt?

Sicarii qua lege dant poenas? Viae

Passim cruore publicae effuso rubent.

2045 Pretio necare crimen est hominem leue.

Quid quaestuosae persequar pecuniae

Vbique mensas? Absque sacrilega lucri

Spe, flagitanti nemo nec egenti dabit.

Cui non rapaces ungue furaci manus

2050 Ad furta prosunt? Inopis et uiduae cadit

Neglecta causa. Vincit insigni nota

Infamiaque iudicum potentior.

Haec facinora cumulata sacrilegiis feret

Deus ultor impunita perpetrarier?

2055 Altis arabit terga sulcis uerberum.

Iam namque acerbus ille uirgas colligit.

Mea dicta mente figite in memori semel.

Non una clades uos manet, triplex manet:

Ferrum, fames, et pestis. Hinc cadauera

2060 Gladio iacebunt, inde truculenta fame

Spargentur, urbem dira populabit lues

Multoque totas funere implebit domos.

Non urbs sepulcris tanta praebebit locum.

Depressa ab imo uallis ad laterum iuga,

2065 Defuncta capiet corpora. Lagenam puer

Da. Sicut ista frangitur testa, Arbiter

Ita Deus huius franget urbis incolas.

R. O execrabile caput attoniti senis!

O me impotentem, o nescium regno frui

2070 Et iure regis! Viuo, nec uiuo Aethere

[p. 72]

Et luce dignus quando me terret ferox

Hominis senectus huius et patiens diu

Nemine manum tenente terrentem fero.

2038 et $s . u$. / et om. KCT 2041 Exhorruistis? Pergo non dixi omnia KCT 2042 Caedes patratas KCT / post 2042 eras. $2044 \mathrm{C} \mathbf{2 0 4 4} \mathrm{mg}$. C $\mathbf{2 0 4 5}$ Hominemque pretio perimere est crimen leue KCT $\mathbf{2 0 4 9}$ ungue] unguine $K \mathbf{2 0 5 4}$ Sine clade uestra durus in iniquos Deus? KCT 2055-2056 om. KCT 2057 in memori] immemori KC $\mathbf{2 0 5 9}$ Ferrum] Hostis KCT 2060 populanti eras. truculenta s. u. et $\mathrm{mg}$. / truculenta] populanti KCT $\mathbf{2 0 6 1}$ populabit] complebit $K C T$ 
Para seus filhos, é um estrangeiro e um hóspede.

A lascívia do sogro corrompe a nora, que vive constrangida.

O irmão tenta seduzir a irmã, e esta o irmão.

Estais arrepiados? ${ }^{80}$ Esta ainda é a parte menor dos crimes.

Que magistrado pune os culpados de homicídio?

Com que lei se castigam os desordeiros? Por todo o lado

a via pública tinge-se com derramamento de sangue.

É crime sem importância matar alguém por dinheiro.

2045

Porque hei-de andar por todo o lado atrás das mesas

de jogo a dinheiro? A não ser com a sacrílega mira do lucro

ninguém dará esmola a um pobre pedinte.

As mãos providas de unhas para roubar

A quem não aproveitam? A causa do pobre e da viúva cai

2050

Esquecida. Vence, por sua ilustre notoriedade

e pela infâmia, o mais influente dos juizes.

Tais crimes acumulados com sacrilégios tolerará

o Deus justiceiro que se cometam impunemente?

Ele fustigar-lhes-á as costas, abrindo-lhes sulcos com o chicote.

2055

A verdade é que Ele já ata as vergônteas, de semblante carregado.

Fixai bem, de uma vez por todas, minhas palavras:

não vos espera apenas uma desgraça, mas três:

a guerra, a fome e a peste. Num lado, estender-se-ão cadáveres

mortos à espada; noutro, uma fome cruel

2060

dispersá-los-á, uma terrível epidemia grassará na cidade

e não haverá casa que não se encha de luto pesado.

A cidade, tão espaçosa, não conterá todas as sepulturas;

um vale profundo encher-se-á de cadáveres amontoados

até ao cume. Passa-me a bilha de barro, meu rapaz.

2065

Tal como esta bilha se estilhaça, da mesma forma Deus, como juiz, aniquilará os habitantes desta cidade. ${ }^{81}$

REI - Existência abominável a deste velho delirante!

Sinto-me impotente, sem saber tirar partido

do poder e da autoridade real! Vivo, mas não vivo

2070

digno do ar e da luz do dia, pois me aterroriza

a velhice feroz deste homem e eu, com infinita paciência,

ninguém me obrigando, suporto sua acção aterrorizadora.

« 2062 Domosque crebro funere sepulcris locum KCT 2063 eras. ub ante urbs / Vrbs tanta praedae mortuis (prae demortuis T) habet breuem KCT 2064 Depressae KCT 2065 capiet] crescent KCT $\mathbf{2 0 6 7}$ frangit $L$ / Ita Deus urbis franget Isaciae incolas KCT $\mathbf{2 0 6 8}$ attoniti] inuisi $K C T \mathbf{2 0 6 9}$ O me potenti nescium (nesciunt $K$ ) regno frui $K C T$ 2070 Raethere $L \quad \mathbf{2 0 7 1}$ Et] Nec KCT $\mathbf{2 0 7 2}$ Homunculus, et ego fero terrentem diu KCT $\mathbf{2 0 7 3}$ om. KC 
PH. Permittis? Eia debitam poenam exigo.

2075 GOD. Cape.

GED. Immo pereat.

PH. Das locum?

R. Ferro abstine.

H. Cur abstinebit? Cur pia est crudelitas?

Occide. Iugulum facile resecandum patet.

R. Age, rape, durum spiritum carcer domet.

PH. Mallem perimere.

\section{H. Caedis?}

PH. Interitum darem.

2080 P. Miser occidi! dimittite inualidum senem.

PH. Fuge, puer.

P. At pro languido hae ualeant preces.

PH. Adeste, fidi milites, loris magum

Vincite ualidis.

H. Carceris ad umbram innocens

Caliginosi more latronum trahor?

2085 PH. Latrone peior, quantulum poenae est tibi?

H. Haec Vltor alto magnus ab Olympo uidet.

PH. Caeco has querelas uinctus effundes loco.

P. Meumne patrem uiuus includi feram?

O terra, tantum muta cur spectas scelus?

2090 Regem mouebo forsitan luctu meo.

Ad genua lacrimis uoluor effusis puer.

Miseresce. Nato da patrem raptum mihi.

Illum perire morte si tristi iubes,

Aetate puerum me iube tenerum mori.

2095 Fas est parentem filio in poenas sequi.

R. Remouete.

P. Ciues parcite exorabiles.

Mollire sinite fletibus regem meis.

R. Abigite, ne clamando me offendat puer.

P. Limen tenebo carceris opacum, miser

$\mathbf{2 0 7 4}$ Permitte, ferro debitam poenam exigam KCT $\mathbf{2 0 7 5}$ Cape] luat KCT $\mathbf{2 0 8 0}$ eras. inf ante inualidum] innocuum KCT $\mathbf{2 0 8 1}$ Fuge] Euge $L$ / post languido] sene deprecor KCT $\mathbf{2 0 8 2}$ Irruite fidi milites, nexu magum KCT $\mathbf{2 0 8 3}$ Vincite ualidis] Tenete ualido $K C T$ $\mathbf{2 0 8 4}$ Caliginosam KCT $\mathbf{2 0 8 5}$ ante poenae] hoc KCT $\mathbf{2 0 8 6}$ Videbit alto summus (ab add. CT) Olympo arbiter KCT $\mathbf{2 0 8 7}$ Querere in opaco uinctus ut meres loco KCT $\mathbf{2 0 8 9}$ post tantum] facere quae potuit nefas KCT $\mathbf{2 0 9 0}$ mouebunt KCT / luctu meo] planctus mei KCT 2091 post genua] uoluor effuso planctu puer $C$ /planctu $m g . K \mathbf{2 0 9 2}$ Miserere $K T$ / nato] princeps $K C T$ 
Fassuro - Permites? Vamos, eu dou-lhe o castigo que merece.

Godolias - Prende-o.

GEDELIAS - Mais: morra.

FAssuro - Dás ordem?

REI - Não uses de violência.

Jeremias - Porque não? Por que razão a crueldade é piedosa?

Mata. A garganta está à vista para facilmente ser cortada.

Rei - Vamos, pega nele. O cárcere domará esse espírito rebelde.

FASSURO - Preferia matá-lo.

JEREMIAS - Tu matares-me?

FASSURO - Dar-te-ia a matar.

Moço - Pobre de mim, estou perdido! Deixai em paz um velho sem forças. 2080

FAssuro - Foge, rapaz.

Moço - Mas atendam às minhas preces por um desvalido.

FAssuro - Vinde cá, soldados leais! Amarrai esse bruxo

com fortes correias.

Jeremias - Sou inocente. Arrastam-me como um ladrão

para a sombra dum cárcere tenebroso?

FASSURO - És pior que um salteador. É bem pequeno castigo que te espera?

2085

JEREMias - O juiz supremo contempla tudo isto do elevado Olimpo.

FAssuro - Soltarás esses queixumes algemado em local escuro.

Moço - Suportarei com vida que levem preso o meu pai?

Ó terra, porque contemplas em silêncio tamanho crime?

Talvez comova o rei com meu choro.

2090

Lanço-me aos teus joelhos chorando como uma criança.

Tem piedade dum filho; restitui-me o pai que me roubaram.

Se ordenares que seu fim seja a triste morte,

deixa que morra também esta criança de tenra idade.

É justo para um filho acompanhar o pai nos castigos.

2095

REI - Afastai-o.

Moço - Poupai-me, cidadãos; sede sensíveis.

Deixai-me enternecer o rei com minhas lágrimas.

REI - Levem-no. Que o rapaz não me indisponha com seus gritos.

Moço - Colocar-me-ei à entrada da sombria prisão. Pobre de mim!

$\longleftarrow 2093$ ante morte] Aut cadere senem (uatem T) KCT 2094 om. KCT 2095 Viuere potuimus ambo possimus mori $K C$ / Orbatus illo uiuo (certa $K$ ) si mors hunc (me $K$ ) manet add. KCT / Eadem sequatur mortis efficiar (leuior effectus $K$ ) comes add. KCT [Trad. "Pudemos viver; possamos ambos morrer, / já que privado dele é a morte certa que me espera. / Que siga o mesmo destino o companheiro que se tornou muito pouco importante"] $\mathbf{2 0 9 6}$ exorabilem KCT 2097 Regis animum mollite pro me perdito KCT 2098 Abigite, cur clamore me laedit puer KCT 2099 Limen tenebo] Limine sedebo $K C T$ / opaco $C T$ opaci $K$ 
2100 Noctem diemque semper in lacrimis teram.

Haec cernis, alme Conditor Olympi, et taces?

Nec rupta flammis nubila coruscis tonant?

Tempora sacrilega quae uident tantum nefas!

PH. Arcete pugnis, agite clamantem foras.

\section{MiLites EXPLORATORES}

2105 EXPL. Quid ante muros agitur hac lenta mora?

Properate, ciues; hostis a tergo ruit.

Audite fremitum. Bellicae clangunt tubae

Curuique litui. Iam quadrupedantum ungulae

Plaudunt citatae.

R. Tempus o nimium breue!

2110 Eia, mora nulla, scandite, et totis uiri

Micate pinnis. Hostis aduentat. Date

Date tela propere; bucinae aeratae crepent.

Vastam per urbem classici murmur sonet.

GOD. Age resonet perculsa tellus classico.

2115 Ad signa miles rapta conueniat ruens.

Clamate "ad arma".

\section{EXERCitvs SOLYMAE}

\section{EX. Arma, arma.}

GOD. Robustas fores

Tenete. Vos excelsa adite moenia.

EX. Conglomerati omnes ciues ad signa coite.

Ferte citi ferrum, date tela, scandite muros.

2120 Vicino iam Marte ferus fremit arma Tyrannus.

\section{NABVZARDANVS, primi dux agminis}

Solymae superbae, perfidae, inuisae arduos

Aspicio muros; conflagraturam rogis

Vrbem coruscis cerno, quam ualidis potens

2100 Noctemque lacrimis cum die effusis (effusus K) teram KCT 2101 post Haec] aspicis micantis KT $\mathbf{2 1 0 3}$ O tempora sacrilega, sceleris et atrocis reos KCT $\mathbf{2 1 0 4}$ Retrahite clamantem, excludite (abigite CT) actutum foras KCT $\mathbf{2 1 0 5}$ Quae segnis ista patriae seruandae (seruanda T) est mora? KCT $\mathbf{2 1 0 7}$ post Audite] murmur agminum KCT $\mathbf{2 1 0 8}$ Curuique litui] Propius 
Passarei dias e noites continuamente em lágrimas.

Ó venerável Criador do Olimpo, vês tais coisas e ficas calado?

As nuvens não trovejam, rasgadas por relâmpagos?

Tempos sacrílegos estes, que contemplam tal impiedade!

FASSURO - Afastai-o a murro. Fora com esse choramingas.

\section{SOLDADOS EXPLORADORES}

EXPLORADOREs - Por que razão tanta demora diante das muralhas?

Apressai-vos, cidadãos, o inimigo precipita-se atrás de nós.

Escutai o alarido. Ressoam as trombetas de guerra

e os recurvos clarins. Já se ouve o ruído dos cavalos

com seus cascos velozes. ${ }^{82}$

REI - O tempo é demasiado curto!

Vamos! Nada de demoras! Subi, ocupai todas as ameias,

soldados. O inimigo vem aí. Vamos, fazei chover sobre ele

dardos velozes. Ressoem as trombetas de bronze.

Que o som do clarim se espalhe pela vasta cidade.

Godolias - Que a terra ressoe, ferida pelo som do clarim.

Reúnam-se os soldados sem demora junto aos estandartes erguidos.

Gritai «às armas!»

\section{EXÉRCITO DE JERUSALÉM}

EXÉrCito DE JERUSALÉM - «Às armas! Às armas!»

Godolias - Defendei

as sólidas portas; dirigi-vos às elevadas muralhas.

EXPLORADORES - Agrupai-vos todos, à sombra dos estandartes, cidadãos. Manejai a espada com agilidade. Arremessai dardos. Escalai as muralhas.

Na iminência dos combates, o Tirano faz ressoar ferozmente as armas.

CENA VI: NABUZARDANO, comandante da linha da frente.

NABUZARDANO - Contemplo as elevadas muralhas da arrogante, da pérfida, da odiosa Jerusalém. Vejo a cidade que vai ser abrasada por violento incêndio, a cidade que o Deus poderoso fará devastar

— canorae. KCT $\mathbf{2 1 1 0}$ eras. nulla ante mora $K /$ totis] latis $K C T \mathbf{2 1 1 3}$ Vbique uasti classici murmur tonet KCT $\mathbf{2 1 1 4}$ perculsa] compulsa KCT $\mathbf{2 1 1 5}$ arma eras. signa s. u. et mg. / Ad arma miles subita conueniens ruat KCT $\mathbf{2 1 1 6}$ GED. pers. $C \mathbf{2 1 1 7}$ eras. Ex post moenia $C$ 2118 Exercitus pers. KCT $\mathbf{2 1 2 0}$ post Marte] fremunt dira arma Tyranni $K C T$ 
Vastabit armis gentis Assyriae Deus.

2125 Cui genua populi curua demissi locant

Tellure in ima, supplice et uultu omnium

Vnum fatentur esse terrarum iubar.

Adeste, plenis oribus qui concauis

Inflare soliti canitis horrendum tubis

2130 Terrete Solymae noxium infidae solum

Ipsoque cantu tecta Solymorum tremant.

\section{Praeco missus ante muros}

Qui regit imperio terras Babylonius heros,

Par Superis, Solymae plenis legionibus instat

Perfidiam ulturus fideique abrupta refixae

2135 Foedera. Ni portas et moenia panditis, ille

Per Superos Numenque suum, per maxima iurat

Sceptra manu quae solus habet, se cuncta ruendo

Fracturum, et flammis templumque et tecta daturum.

\section{OPPIDANI ex muro}

Non tua dicta ferox Solymorum pectora terrent.

2140 Dic animis accedat atrox qui territat hostem

Vaniloqua lingua et lituorum uoce canora.

Ferte citi ferrum murosque ascendite, ciues.

Hostis adest pictisque inuadit moenia signis.

\section{NABVCDONOSOR IMPERATOR}

Armis coacta gens bis imperium pati

2145 Diuina sceptri iussa detrectat mei?

Huiusque molem spernit ingentem manus?

Caeline claris inditum stellis caput,

Audet inimicum ferre, nec nostri timet

Furoris aestum? Cerno conclusas fores.

2150 Munita propugnaculis uideo nouis

Moenia. Sed altum non uident murum sibi

$\mathbf{2 1 2 5}$ demissa $L \mathbf{2 1 2 8}$ concaui $K \quad \mathbf{2 1 3 0}$ solum] genus $K C T \quad \mathbf{2 1 3 1}$ Mixtaque tubarum classica sonori increpent KCT $\mathbf{2 1 3 5}$ ille] urbis KCT $\mathbf{2 1 3 7}$ cuncta ruendo] pergama ferro KCT 2138 templumque et] gladioque haec KCT $\mathbf{2 1 4 5}$ detractat $K C T E \mathbf{2 1 4 8}$ nostrae $K C T$ 
pelos valorosos exércitos da nação assíria,

o Deus perante quem os povos se ajoelham,

prostrados por terra e, em atitude suplicante,

confessam que é Ele a única luz de toda a terra.

Aproximai-vos, vós que, habituados a soprar a plenos pulmões,

fazeis ressoar pavorosamente as côncavas trombetas.

Assustai a terra criminosa da infiel Jerusalém

e que as casas dos seus habitantes estremeçam com tal som.

\section{ARAUTO, enviado junto das muralhas}

O herói da Babilónia que governa a terra com a sua autoridade, semelhante aos deuses, avança sobre Jerusalém com suas legiões a fim de vingar a traição e a violação dos acordos firmados em boa-fé. Se não lhe franqueardes as portas das muralhas, ele jura, pelos deuses do alto e seu poder e pelos poderosos ceptros que só ele empunha, que tudo arrasará e entregará às chamas o templo e as casas. ${ }^{83}$

\section{CIDADÃos, do alto da muralha}

Tuas palavras não atemorizam os habitantes de Jerusalém, ó arrogante. Aproxime-se confiante o cruel que aterra o inimigo com palavras vãs e o ruído dos clarins.

Empunhai rapidamente a espada e subi às muralhas, cidadãos. O inimigo aproxima-se e invade-as com seus estandartes.

\section{CENA VII: GENERAL NABUCODONOSOR}

A nação duas vezes forçada a submeter-se pela força das armas recusa as ordens divinas de meu ceptro?

Ela despreza o peso enorme desta dextra? Ousa ter como inimigo quem foi colocado sobre os astros do firmamento? Não receia a violência da minha fúria? Vejo as portas fechadas, as muralhas reforçadas com novas fortificações. Mas não percebem que muralhas elevadas 
Nil profuturum, saxa cum dederint meis

Rotata sonitum machinis et plurimus

Testudine aries actus obiecta, aeneis

2155 Aperire ueniet cornibus murum? Erigunt

[p. 75]

Infixa pinnis signa turritis, mihi

Hastae minaces cuspidem ostentant suam.

Ego tamen hastas perfidis alias dabo

Quae penitus animam pectore refosso impiam

2160 Migrare cogant pallidi ad Auerni lacus.

Apud Acherontem, quisquis aeternum rogum

Formidolosi carceris custos habes,

Impone flammis ligna, nam ferro meo

Concisa mittam millia aucta millibus

2165 Animaque latebras penitus implebo tuas.

Laetare, multa uictima sacrum tibi

Epulum paraui. Tartari Manes uoca.

Omnes habebunt unde se large expleant.

Ego me reprendo, iure do culpam mihi,

2170 Quod dextra bello non semel uictrix male

Pepercit urbi. Debuit inundans cruor

Opplere quidquid uiuit intra moenia,

Inuisa Superis et mihi. Qualem Noti

Deproeliantes aequore in uasto ratem

2175 Hiante pelagi deuorant nigri sinu,

Imisque fundi collocant haustam uadis,

Talem procellam caede populante omnia

Hic excitare debuit, ut nati in patrum

Sanguine natarent, donec extremum halitum

2180 Ipsum bibentes sanguinem diffunderent.

Plus quam decebat cur pius, clemens fui,

Et mitis hostis? Video quid faciant leui

Pugnata motu bella: uictori afferunt

[p. 76]

Iteranda bella. Si represissem ferox

2185 Animos superbae perfidos gentis, meum

Non illa rursus prouocasset impetum.

Genti peperci rege sublato improbo

Et mancipato carceri Babylonio.

2152 dederint] sonitum KCT 2153 sonitum] dederint $K C T \mathbf{2 1 5 4}$ aeneis] aereis $K C T$ $\mathbf{2 1 5 5}$ Erigunt] nitent KCT $\mathbf{2 1 5 6}$ Infixa] Erecta KCT $\mathbf{2 1 5 9}$ pectore refosso] corpore recusso KCT 2160 Migrare cogant] Exire iubeant KCT / lacum KCT 2164 Concisa mittam] Ad te remittam KCT $\mathbf{2 1 6 5}$ latebras] tete KCT/ tuas] impia KCT $\mathbf{2 1 6 9}$ iure - mihi] meque stultitiae 
de nada lhes servirão quando zoarem as pedras lançadas pelas minhas máquinas de arremesso e os vários aríetes pressionando com suas pontas de bronze, ${ }^{84}$ sob a protecção da tartaruga, acabarem por fender as muralhas? Erguem contra mim estandartes fixados nos torreões das ameias. As lanças exibem ameaçadoramente suas pontas aguçadas.

Mas eu apresentarei a esses malvados outras lanças que obrigarão essas vidas ímpias, com o peito trespassado, a emigrar para os lagos do pálido Averno.

Quem quer que tu sejas nas margens do Aqueronte, ${ }^{85}$

ó guarda do cárcere medonho, onde tens túmulo eterno,

deita lenha na fogueira, pois minha espada

fará juntar milhares de mortos a outros tantos:

encherei completamente de almas os teus covis.

Alegra-te, preparei-te um festim sagrado

com muitas vítimas. Manda vir os Manes ${ }^{86}$ do Tártaro.

Todos terão com que se saciar plenamente.

Eu censuro-me e com razão atribuo culpas a mim mesmo.

Após ter vencido esta cidade na guerra,

poupei-a injustamente. O sangue deveria ter inundado

e submergido tudo quanto vive dentro dessas muralhas,

odiosas aos deuses e a mim. Tal como os ventos Notos, ${ }^{87}$

redemoinhando na vasta superfície do mar,

devoram a embarcação no abismo cavado do negro oceano

e, absorvendo-a, fazem-na baixar até às profundezas do mar,

idêntica tempestade deveria eu ter desencadeado,

com uma chacina devastadora, ao ponto de os filhos

nadarem no sangue dos pais até soltarem o derradeiro suspiro,

afogando-se no próprio sangue que engoliam.

Porque fui um inimigo misericordioso, clemente e benévolo,

mais do que convinha? Eis no que dão

guerras travadas com ardor moderado: forçam o vencedor

a empreender novas guerras. Se tivesse reprimido com dureza

o espírito traiçoeiro deste povo orgulhoso,

ele não teria provocado de novo a minha fúria.

Condescendi com o povo, livrando-o dum rei perverso,

que encerrei numa prisão da Babilónia.

« arguo KCT $\mathbf{2 1 7 0}$ Quod - bello] Haec dextra quoniam KCT/ malae KCT $\mathbf{2 1 7 1}$ in undas $K$ $\mathbf{2 1 7 5}$ post pelagi] uortice nigrantis uorant $K C T \mathbf{2 1 8 0}$ diffunderent] morti darent KCT $\mathbf{2 1 8 4}$ Iteranda] Secunda $K C T \mathbf{2 1 8 5}$ Animos] Mentem $K C T$ / perfidos] perfidam KCT 2188 Babyloniae $K C T$ 
Tractanda patruo sceptra Sedeciae dedi.

2190 Et ille nostri muneris nimium memor,

Pro pace bellum fidus indixit mihi.

Populis timendum testor hoc sacrum caput

Sceptrumque iuro, quod manu fulget mea,

Numenque nostro si quod est maius poli

2195 Super alta clari sydera: in patriae lares

Non esse reditum militi dandum meo,

Donec reuulsis moenibus ferro et face

Vrbem iacere dedero prostratam solo.

Tuque Sedecia deditum morti caput

2200 Deuota nostro uictima furori cadas.

Quis mihi nocentem prole cum tota patrem

Captum, ligatum, sordidum, abiectum dabit?

Eia eia miles nulla sit rebus mora.

Nostrae uocati adeste militiae duces.

\section{NABVCDONOSOR. NABVZARDANVS.}

EXERCITVS BABYLONIVS. NVNTIVS

2205 NABVC. Gentis inimicae uidimus tandem caput

Arcemque sceptris semper odiosam meis.

Abolere ferro penitus ac flamma paro

Stirpemque toto uellere nocentem solo.

Vos castra propius agite, congesta aggerem

[p. 77]

2210 Tellure circumponite, et murum premat

Hinc miles, inde non malum leuius fames.

Nequis iuuare possit obsessos ope.

Omnes ad urbem claudite operibus uias.

In nationes ceteras clementia

2215 Sit nostra sole clarior, in istud genus

Sobolis Hebraeae nulla sit pietas, nihil

Humanitatis blandus ostendam meae.

Vna ira regnet, ira concutiat domos

Viros, mulieres, paruulos, iuuenes, senes.

2220 Huc o Nabuzardane, primus omnium,

2189 sceptra] regna $K C T \mathbf{2 1 9 1}$ fidus] stultus $K C T \mathbf{2 1 9 2}$ hoc] et $K C T \mathbf{2 1 9 9}$ neci eras. morti s. u. $\mathbf{2 2 0 0}$ cadas] occidas KCT $\mathbf{2 2 0 2}$ sordidum] supplicem KCT $\mathbf{2 2 0 3}$ eia2 s. u. C $\mathbf{2 2 0 4}$ eras. Adeste ante Nostrae / Adeste magni gentis Assyriae duces KCT 2205 scae. non ind. C $\mathbf{2 2 0 6}$ sceptris eras. et ceptis $\mathrm{mg}$. C ceptis $K T \mathbf{2 2 0 7}$ Abolere penitus igne uastante 
Entreguei a realeza a Sedecias, seu tio, e este, bem lembrado da nossa mercê, abusando da confiança, em vez de paz declarou-me guerra.

Juro pela minha sagrada existência, temível para as nações; juro por este ceptro que resplandece em minhas mãos e pela divindade, se alguma existe maior que a nossa sobre as elevadas constelações do luzente firmamento: meus soldados não serão autorizados a regressar a casa sem que, destruídas as muralhas pelo ferro e pelo fogo, eu mostre a cidade totalmente arrasada.

E tu, Sedecias, vida destinada à morte, hás-de cair, como vítima entregue à nossa fúria.

Quem me trará o criminoso pai e toda a sua prole, cativo, algemado, sujo e desprezível? Vamos, vamos, soldados, não percais tempo. Vinde cá, generais alistados no nosso exército.

\section{CENA VIII: NABUCODONOSOR, NABUZARDANO, Exército de BABILÓNia, MENSAgeiro}

NABUCODONOSOR - Contemplamos, finalmente, a capital da nação inimiga 2205 e a sua cidadela sempre odiosa ao meu poderio.

Apresto-me a aniquilar de todo, pela espada e pelo fogo, essa raça funesta e a fazê-la desaparecer em toda a terra. Fazei chegar os exércitos para mais perto; em redor edificai baluartes, amontoando terra; e tanto os soldados como a fome (mal não menor) apertem o cerco às muralhas. Que ninguém possa levar auxílio aos sitiados.

Fechai qualquer acesso à cidade.

Nossa clemência para com as demais nações poderá ser mais brilhante que o sol, mas para com este rebento da raça hebreia, não haja qualquer tipo de compaixão; não lhes mostrarei qualquer sentimento de humanidade. Apenas reine a cólera e essa cólera faça estremecer os lares, os homens, as mulheres, as crianças, os jovens, os velhos. Aproxima-te, Nabuzardano, comandante supremo do meu exército;

$\longleftarrow$ apparo KCT $\mathbf{2 2 0 8}$ nocentem] maleficam KCT $\mathbf{2 2 1 0}$ muros KCT $\mathbf{2 2 1 1}$ eras. .i... ante malum / Hinc hostis, inde grauior inimico fames KCT $\mathbf{2 2 1 2} \mathrm{Ne}(\mathrm{Nec} C$ ) qua iuuari perditi possint ope KCT $\mathbf{2 2 1 7}$ Humanitatis impero fieri meae KCT $\mathbf{2 2 1 8}$ post regnet] una KCT $\mathbf{2 2 2 0}$ Te te Nabuzardane, praeficio omnibus $K C T / \mathrm{te} 2 \mathrm{mg}$. C 
Age quem requiro Marte sub nostro ducem.

NABVZ. Honoris ergo flecto delati genu

Dextramque supplex libo diuinam mihi.

Parebo domitor magne terrarum tibi.

2225 Qua uallis illa curua descendit suo

Nemorosa luco, militis partem tui

Armis decoram tendere latentem iube.

Ego summa ualidis insidebo culmina

Agminibus, inde uerberabunt machinae

2230 Murum rotantes saxa. Cum perruperint

Munitiones, militi signum dabo.

Inuadet hinc et inde militaribus

Vrbem maniplis, impetu magno premet,

Et occupabit forsan obsessos.

NABVC. Bene est.

2235 Belli peritus omnia ex usu facis.

\section{OBSESSORVM CLAMOR}

Ne trepidate, uiri; patriam defendite fortes.

NABVC. At quem repente sentio tumultum? Erigunt

Sese oppidani.

CL. Patriam defendite, ciues

NABVC. Fremunt cohortes; laeta per muros sonant.

2240 Signis lacessunt nosque militaribus.

CL. Assyrii quis Regis opes, quis castra timebit,

Si uenit auxilio nobis Aegyptia tellus?

Explicat en totis Nechao rex agmina campis,

Innumeros infrenat equos cogitque sub armis

2245 Stagnantem magno qui potant flumine Nilum.

Iam propior micat, et fulgentes aere cateruas

Accelerare iubet currusque praeire uolantes.

NABVZ. Aegyptus illo murmure in laeto est frequens.

NABVC. Opemne Solymae barbara Aegyptus feret?

2250 NABVZ. Hoc est, maligno Nechao rex ausu tuis

Opponit arma uiribus.

2223 supplex libo] dextra tango KCT $\mathbf{2 2 2 5}$ descendit $m g$. Cx; descensit eras. $C$ / suo] cauo KCT $\mathbf{2 2 2 7}$ tendere latentem] sustere tremendis KCT $\mathbf{2 2 2 8}$ post ualidis] uestiam agminibus iuga $K C$ 2229-2232 om. KCT 2233-2234 Neque mora fient machinae, ac uno impetus Diuersus urbem tempore obsessam premet KCT $\mathbf{2 2 3 5}$ Nabucdonosor pers. KCT 2236 om. KCT 2238 post oppidani] laeta per muros sonant KCT / om. ciues post defendite E 
comporta-te como o chefe que eu exijo na nossa guerra.

NABUZARDANO - Dobro os joelhos pela honra concedida

e, como suplicante, beijo tua dextra que tenho por divina.

Obedecer-te-ei, excelso soberano da terra.

Por onde desce aquele vale cavado, de bosque mui denso,

ordena que parte do teu exército se esconda aí,

devidamente armada, espalhando-se nessa área.

Tomarei posição no cimo dos cumes,

Com fortes batalhões, donde as catapultas fustigarão as muralhas,

Lançando pedregulhos. Assim que estas abrirem brechas,

farei sinal aos soldados. Eles invadirão então a cidade,

dum lado e doutro com os manípulos ${ }^{88}$ militares,

atacá-la-ão com toda a violência

e talvez se apoderem dos sitiados.

NABUCODONOSOR - Muito bem!

Como perito de guerra, fazes tudo de acordo com as normas.

2235

\section{CLAMOR DOS SITIADOS}

ClAmor - Não vacileis, soldados; defendei vossa pátria com valentia.

NABUCODONosor - Mas que súbito alvoroço estou ouvindo? ${ }^{89}$

Os citadinos retomam coragem.

CidAdãos - Defendei vossa pátria, cidadãos.

NABUCODONOSOR - Os batalhões agitam-se. Soltam palavras de euforia ao longo das muralhas e provocam-nos com os estandartes militares.

CIDADÃos - Quem receará os efectivos militares do rei assírio, os seus arraiais, se vem em nosso auxílio a terra do Egipto?

Vede, o rei Necao desdobra seus batalhões nos campos de batalha, atrela inúmeros cavalos e faz alistar em seu exército quantos bebem da água do pantanoso Nilo de largo caudal.

Já brilha mais perto e ordena aos esquadrões, revestidos de bronze, que se apressem, e aos carros que marchem velozes na sua frente.

NABUZARDANO - O Egipto é conhecido por este tipo de algazarra alegre.

NABUCODONOSOR - O bárbaro Egipto virá auxiliar Jerusalém?

NABUZARDANo - Exactamente. O rei Necao, com temerária ousadia, lança seus exércitos contra os teus.

— 2239 om. KCT 2240 Lituis sonori concrepant laeti tubis KCT $\mathbf{2 2 4 1}$ qui1-2 L / castra] bella KC $\mathbf{2 2 4 2}$ tellus Aegyptia nobis? KCT $\mathbf{2 2 4 3}$ Explicat] Expedit KCT $\mathbf{2 2 4 4}$ Innumeris exundat equis KCT $\mathbf{2 2 4 5}$ magno] liquido KCT 2247 Inque Paraetoniis belli citat arma quadrigis KCT 2249-2251 NABVC. Auditis? ecquid barbara auxilium tulit - Niliaca soboles? forsitan contra meas - Vires maligno Nechao sese ausu mouet? KCT 
NABVC. Nechao mihi?

NABVZ. Id suspicabar. Siquid est certum, breui

Rei uniuersae nuntium accipies. Virum

Adire fidum barbaram iussi Pharum,

2255 Motus referret leuis ut Aegypti tibi.

\section{NvnTivs, ab Aegypto}

NABVC. Auditis? Ecquis propior increpuit sonus?

Pulsauit aures bucinae raucae canor.

NABVZ. Speculator agili missus aduentat gradu.

Accede, miles, fare. Quid portas noui?

2260 N. Aegyptiorum terra pharaonum mihi

Lustrata patuit. Nechao rex pharao undique

Collegit arma, curribus fidens, uenit.

Hostis superbus agmen incauta trahit

Velocitate. Credit aduentu suo

2265 Mox liberandam e manibus hanc urbem tuis.

NABVC. Colligite raptim castra, et hinc exercitu

Properate iusto. Nulla sit factis mora.

Hosti ruentes signa monstremus, prius

Quam fama adesse militem prodat meum.

2270 Subito tumultu fusa profligabitur

Nechaonis acies. Impetum nec enim feret,

Magisque caedes, pugna quam nobis erit.

Pharium tyrannum clade multatum graui

Vbi dissipatis ordinibus aspexero,

2275 Belli cruentus uictor huc molem feram.

Vrbem deinde territam Nilotici

Fuso fugatoque Nechaonis milite,

Diruere nobis quantulus fiet labor!

Sic sic rebelles persequar, sic hostibus

2280 Adero, tueri qui meos hostes uolunt.

Ego rex docebo regulum Aegypti leuem

Aliena uelle fortiter defendere,

A clade gentem eripere cum nequeat suam.

2256 Factum perite, sed quis increpuit sonum $K C T \quad \mathbf{2 2 5 8}$ missus] mixtus $L \quad 2259$ NABVC pers. KCT $\mathbf{2 2 6 5}$ Mox] Fore KCT 2266 Collige L/ raptim eras. et $m g$. C $\mathbf{2 2 6 7}$ Nec moram in factis duces KCT 2268-2277 Tolerate segnem, barbarae Aegypti petam - Inopinus agmen antequam muros leuis - Hos cernat hostis Nechao, quem fusum semel - Vbi dissipatis ordinibus 
NABUCODONOSOR - Necao contra mim?

NABuZARDANo - Já o suspeitava. Se realmente algo se passa, em breve saberás tudo por um mensageiro, homem de confiança, a quem ordenei que se dirigisse a terras de Faro, para te referir, em pormenor, as movimentações do insensato Egipto.

\section{CENA IX: MensageIro, chegado do Egipto.}

NABucodonosor - Ouvis? Que som é este que se fez ouvir mais perto? Chegou-me aos ouvidos um som de rouca trombeta.

NABUZARDANO - Aproxima-se a passos rápidos o espião por mim enviado. Apresenta-te, soldado! Fala. Que novas trazes?

Mensageiro - Percorri toda a terra dos faraós do Egipto.

2260

O faraó Necao reuniu exércitos de todo o lado

e dirige-se para cá, confiante em seus carros.

O inimigo conduz altivamente o exército, em marcha serena.

Ele acredita que, com sua chegada, rapidamente esta cidade se deverá ver livre de tuas mãos.

NABucodonosor - Dirigi-vos de imediato ao acampamento

e parti de lá com duas legiões. Façam-no sem demora.

Ergamos os estandartes e precipitemo-nos sobre o inimigo, antes que a fama espalhe a notícia da presença de meus soldados.

Surpreendido por súbito ataque, será destruído

o exército de Necao. Nem suportará o ímpeto de nossa investida

e, mais do que um combate, teremos uma chacina.

Quando eu vir o tirano egípcio castigado

com pesada derrota e seu exército desbaratado,

conduzirei para aqui o peso da guerra, como cruel vencedor.

Destruir esta cidade aterrorizada,

com os soldados do egípcio Necao dispersos e em fuga,

pouco trabalho nos dará.

É assim, é assim que eu perseguirei os rebeldes; assim me apresentarei

perante os inimigos que querem proteger os meus inimigos.

$\mathrm{Eu}$, que sou rei, ensinarei esse insensato reizinho do Egipto

a querer defender corajosamente o alheio,

quando não consegue livrar da destruição o seu povo.

$\longleftarrow$ aspexero] Vrbem hanc, genusque perfidum bello et fame KCT $\mathbf{2 2 7 6}$ eras. perfidam, p.. ante territam $\mathbf{2 2 7 8}$ fiat $K \mathbf{2 2 8 1}$ Ego te docebo rector Aegypti insolens KCT 2282 post uelle] pergama tueri manu KCT $\mathbf{2 2 8 3}$ nequeas tuam $K C T$ 
Sonent canora tympana, intento gradu

2285 Festinet acies, ipse postremus sequar.

NABVZ. Refige signa signifer. Miles pedem

Efferto castris. Tubicen horrendum cane.

Expone magni praeco iussa principis.

PR. Ille deum Superi quem terris esse dederunt,

2290 Finibus imperium nullis metaque regentem,

Durius obsessae pressurus moenia gentis,

Signa Paraetonium uictor mouet hostis in hostem.

At postquam Phariae dominis dominabitur orae

Eruet hanc ferro flammisque sequacibus urbem.

2295 EX. Regem uince Phari, fidentem curribus; inde

Rursus signa ferens Solymam populabere uictam.

\section{Chorvs Tertivs}

Qui regna putat statura diu

[p. 80]

Rege tyranno, scelerumque duce,

Oculos Solymam uertat in urbem,

2300 Documenta dabit. Non ita pronis

Fugiunt cautes montibus actae,

Vt sceleratae ruit urbis honor,

Impius in qua Rex sceptra gerit,

Nescius aequis legibus aulae

2305 Veneranda suae iura tueri.

Heu flagitiis laxat habenam

Nec iustitiae trutina pendit

Sontibus atri carceris umbram,

At sincerae mentis apertam

2310 Esse futuram ciuibus aulam.

Nec pius orat Numen ut alta

Ex arce poli defendat opes.

Osor auitae sed pietatis

Aut alma procul sacra relegat,

2315 Aut noua fingit numina cultor.

Vnde auxilium speret habendum

2285 Festinet acies] Se moueat agmen KCT / Age iam Nabuzardane compone et rege NABVZ. Conamur omnes quae placent regi obsequi add. KCT [trad. "Vamos, Nabuzardano, alinha as tropas e comanda-as. - Nabuz. Esforcemo-nos todos por cumprir o que é do agrado do nosso rei."] $\mathbf{2 2 8 7}$ post castris] Ite, tu quate classicum KCT $\mathbf{2 2 8 8}$ Animose Praeco redde clamorem Deis - Superis timendum. PR. Post tubam horrendam cano add. KCT 2289 quem] 
Façam rufar os sonoros tambores. Que o exército se apresse em marcha enérgica. Eu seguirei na retaguarda.

NABUZARdAno - Porta-estandarte, ergue os estandartes. Soldados, abandonem o acampamento. Trombetas, soai assustadoramente.

Arauto, faz ouvir as ordens do grande imperador.

Arauto - Aquele a quem os deuses concederam que a terra o tivesse como deus regendo um império sem fronteiras nem limites,

para pressionar mais fortemente as muralhas da nação sitiada, faz avançar vitoriosamente seus estandartes contra o inimigo paretónio. Mas depois de se apoderar das terras do faraó, arrasará esta cidade pela espada e pelas chamas devoradoras. Exército - Vence o rei do Egipto, confiante nos seus carros, e, 2295 regressando depois com teus estandartes, devastarás Jerusalém vencida.

\section{CORO III}

Quem julgar que subsistirão por muito tempo reinos com reis tiranos e chefes de criminosos, volte seus olhos para a cidade de Jerusalém e dela retire lições. Não. Tal como as rochas resvalam pelas encostas dos montes assim se desfaz a honra duma cidade criminosa, onde o poder está nas mãos dum rei perverso, que não sabe proteger com leis justas o venerável direito emanado de sua corte.

Ai! Ele dá livre curso a escândalos e não pondera, com a balança da justiça, para os criminosos a sombra do tenebroso cárcere, e para cidadãos de espírito recto as portas franqueadas do palácio. Nem suplica piedosamente a Deus que de sua elevada cidadela lhe defenda as riquezas. Pelo contrário. Avesso à religião de seus avós, ou proscreve o culto sagrado ou cria novos deuses para adorar. Quando o estado receia danos,

« qui $K \quad \mathbf{2 2 9 1}$ moenia] pergama KCT 2293 dominis Phariae KCT / dominus $L \mathbf{2 2 9 5}$ Vince Phari regem KCT $\mathbf{2 2 9 6}$ More gregis Solymos manda implacabilis Orco KCT 2298 scelerum K 2300-2301 Non - actae] Non ita pronis montibus actae - Fugiunt cautes KCTM / mentibus $L$ 2302 ut - honor] uelut incestae - Ruit urbis honor KCTM / orbis $L$ 2303-2317 om. KCTM 2306 Heu] Vbi $E 2314$ legat $L$ 
Cum res metuit publica damnum?

Discite Reges munire fide

Vera imperium cultuque Dei,

2320 Et iustitiae ponere morem,

Vt supplicii culpa timore

Correpta, metu liberet urbes,

Et sua tollat praemia uirtus.

His siqua manent, stabilita manent

[p. 81]

2325 Regna columnis. Sustinet aestum

Robore claui fulta carina,

Quamuis tumidum saeuiat aequor.

Eadem quouis fluctuat Euro

Bibitura fretum, si male prudens

2330 Sedet excusso nauita clauo.

Sic imperium, sic aula uiget,

Cum religio spirat ab alto

Aethere, uentis laeta secundis,

Clauumque tenent iura, nec ipso

2335 Flectere cursum rege uolente,

Aequa relinquunt. Non plena fero

Regna tuentur milite castra,

Tangensue cauam machina lunam,

Aenea ferri iaculata pilas,

2340 Sed pietatis cura tuendae,

Rectumque sequens orbita iuris.

O Rex Solymae, non tibi currus,

Non pharaonis proderit aurum.

Vincet Babylon. Carcere uates

2345 Conditur insons, qui uera monet.

At tempus erit, uincula iusto

Quo dempta seni, bracchia demens

In tua migrent.

2318-2319 Discite - Dei] Discite reges - Sacra imperium munire fide - Et amore dei KCTM 2320-2336 om. КСТM 2334 Clauemque L $\mathbf{2 3 3 6 - 2 3 3 7 ~ N o n ~ - ~ c a s t r a ] ~ R e g n a ~ t u e n t u r ~ - ~ N o n ~}$ plena fero milite castra KCTM 2339 om. KCTM 2340 pietatis] iustitiae KCTM 2341 om. KCTM 
donde esperará obter auxílio?

Aprendei, reis, a defender o poder

com a fé verdadeira e o culto autêntico de Deus,

e a implantar a prática da justiça,

para que a culpa, levada pelo temor

do castigo, liberte do medo as cidades.

e a virtude erga seus troféus.

Se alguns reinos se mantêm,

é sobre estas colunas que eles se firmam.

Resiste à fúria das águas o barco apoiado na solidez do leme, ${ }^{90}$

ainda que o ameace o mar em fúria.

Balança o mesmo barco sob ventos de sudoeste

até naufragar, se marinheiro pouco experiente

o deixa à deriva, solto do leme.

2330

Assim também floresce um reino, assim prospera uma corte,

quando o temor de Deus sopra do alto,

feliz com ventos de feição,

e são as leis a segurar o leme,

e mesmo querendo o rei desviar seu curso,

não abandonam a equidade. Arraiais repletos

de feroz milícia não protegem reinos,

nem catapultas de bronze disparando bolas de ferro

até à face cavada da lua,

mas a rectidão que segue a via do direito.

2340

Ó Rei de Jerusalém, nem os carros

nem as riquezas do faraó te serão úteis.

Babilónia vencerá: o inocente profeta

está encerrado no cárcere,

ele que te admoesta com verdade.

2345

Mas virá tempo em que os grilhões

retirados ao justo ancião hão-de-passar

para teus braços, insensato.

« 2346 At] Sed KCTM $\mathbf{2 3 4 6 - 2 3 4 8}$ uincula - migrent] Quo dempta seni uincula iusto - In tua demens bracchia migrent KCTM 


\section{ACTVS QVARTVS}

\section{Pver Hieremi[ae] et Hieremias inclusus.}

P. Miserere, Genitor alme, genitoris mei.

2350 Praesente uatem subleua auxilio tuum, Quem turbulenta factio malorum premit.

Rex, impiorum primus in factis comes, Vmbra in silenti carceris taeterrimi, Squalere turpi patitur innocuum situ.

2355 O terra bruta, quando sustinuit senem Nil triste uitae crimine merentem suae, Vt parricidam carcere includi horrido. Ab urbe Solyma pulsa cum iura exulent Legesque, mirum ne sit adfligi bonos 2360 Impune, contra posse grassari malos. Fide exulante debilis uirtus timet, Magisque metuit qui magis iustum colit. Heu obseratas carceris cerno fores.

Ego hanc inopiam quantulae est paruae dapis

2365 Vati afferebam. En prandium sancti senis :

A fonte gelido liquidus acceptus liquor, Atque hic labore panis inuentus meo. Scrutabor, aliqua rima si forsan patet, Vt expetito uatis alloquio fruar.

2370 Vigilasne genitor?

H. Ecquis inclusum uocat?

P. Ego ille fidus corporis custos tui.

H. Vocemne, fili care, percipio tuam?

P. Fidum ministrum, mi pater.

H. Tristi obsitum

Poedore, uinctum carcere in nigro uoca,

2349 alme] summe KCT 2350 eras. Vatemque ante Praesente uatem] Vatemque prompto KCT 2353 silente L $\mathbf{2 3 5 5}$ bruta] dura KCT $\mathbf{2 3 5 6}$ triste] tale KCT/ suo KCT $\mathbf{2 3 5 7}$ post carcere] inclusum tenent $K \quad \mathbf{2 3 5 9}$ ne] non $C T$ que $K \quad \mathbf{2 3 6 3} \mathrm{Heu}$ ] En $K C T \mathbf{2 3 6 4}$ quantulae 


\section{ACTO IV}

\section{CENA I: MoçO e JeREMIAS preso}

Moço - Pai excelso, de meu pai tem piedade;

vem já em auxílio do teu profeta,

mal tratado pelo facciosismo desordeiro dos ímpios.

O rei, conivente com eles, é o grande culpado.

Permite que um inocente permaneça em sombrio cárcere,

rodeado de tétrico silêncio, imundo em local hediondo.

Ó terra bruta! Um ancião em nada merecedor de quaisquer agravos

2355 por crimes da sua vida, ousou ele encerrá-lo em cárcere horrível, como se de um parricida se tratasse.

Uma vez que o direito e as leis estão banidos de Jerusalém, não é de admirar que os justos sejam atormentados, enquanto os maus podem passear impunemente.

Na ausência da boa-fé, a frágil virtude receia,

e mais receia quem mais busca a rectidão.

Oh! Vejo as portas da prisão fechadas.

Trazia esta ligeira refeição para o profeta.

Reparai no almoço do venerável ancião:

água pura, recolhida em gélida fonte,

e este pedaço de pão que tanto me custou a encontrar.

Explorarei as paredes em busca de alguma fresta

para desfrutar da desejada conversa com o profeta.

Estás acordado, meu pai?

JEREMIAS - Quem chama por este prisioneiro?

Moço - Sou eu, o fiel protector da tua vida.

JEREMias - Será que é a tua voz que ouço, meu filho querido?

Moço - O teu dedicado ajudante, meu pai.

JEREMIAS - Sou um prisioneiro

encerrado em tenebroso cárcere, atolado em hedionda imundície.

$\longleftarrow$ - dapis] quantula est parui cibi KCT 2365 En om. KCT 2366 gelido E1; gelidus E / acceptus] extractus KCT $\mathbf{2 3 6 8}$ post scrutabor] aliquae forte si rimae patent KCT $\mathbf{2 3 7 1}$ ille] nempe KCT 2374 carcerecin nigro] carceris nigri $K C T$ 
2375 At non parentem. Nolo tam miserum patrem

Habeas, miserias ne tibi relinquat suas.

P. Immo, has relinque, namque deliciae bonis

Habentur illae.

H. Videat e caelo Deus,

Amore cuius subdidi neruo pedes

[p. 83]

2380 Manusque manicis, et neci dedam caput.

P. Videbit, immo scelera iam gentis uidet

Immania suae. Signa uindictae prope

Fulsere muros.

H. Clausus in uasto hoc specu,

Scio quid agatur. Cuncta mihi monstrat Deus.

2385 Victa redibit grauior Aegypto inclitus

Nabucdonosor.

P. Iuncea in cista dapem

Quam porto, si qua ianua est, intro inferam.

H. Hinc disce quanta saeuiant in me mei

Crudelitate. Corpus est ferro graue.

2390 Tenebricoso carcer est barathro horridus.

Artus inedia languidi marcent. Diem

Solemque prohibent aspici clauso a sene.

P. Quis hostis hostem claudit hoc umquam modo?

H. Aeterne caeli Rector, haec patiens fero,

2395 Quia innocenter ob tui causam fero.

Aliter, quis hominum (silice de dura licet

Prognatus esset) hisce duraret malis?

P. Non teneo lacrimas.

H. Parce, mi fili, meas

Prohibent uidere quando conclusae fores.

2400 P. Causam doloris non fero atrocem mei.

H. Cohibe dolorem. Parce miserando seni.

Compesce fletum.

P. Rector aurati poli,

Qui prodeunte sole concedis diem

Noctemque terris ad quiescendum uaga

2405 Permittis umbra nubilam, exorabile

Aduerte Numen; aure me leni parum

Tolera querentem. Si quibus sancta est tui 
Não me chames pai. Não quero que tenhas um pai tão miserável, 2375 para não teres de herdar as suas misérias.

Moço - Pelo contrário, deixa-as para mim, pois quem é bom considera-as delícias.

Jeremias - Que Deus o veja, lá do céu, por amor de quem tenho os pés acorrentados

e as mãos algemadas, e entregarei minha vida à morte.

2380

Moço - Ele verá, ou melhor, Ele já vê os crimes horríveis

de seu povo. Os sinais da vingança reluziram

junto das muralhas.

JEREMIAS - Embora encerrado neste antro enorme,

eu sei o que se passa. Deus faz-me ver tudo.

Vencido o Egipto, regressará mais ameaçador

2385

o ilustre Nabucodonosor.

Moço - Numa cestinha de junco, trago-te

uma refeição. Se houver alguma abertura, poderei fazê-la entrar.

JEREMiAs - Avalia por aqui com que crueldade me atormenta

a minha gente. Tenho o corpo carregado de ferros.

O cárcere é medonho, com um tenebroso abismo.

2390

Os membros vão ficando debilitados por falta de comida

e não permitem a um velho avistar a luz do sol.

Moço - Alguma vez se viu um inimigo enclausurar outro deste modo?

JEREMIAS - Suporto pacientemente tudo isto, ó Rei Eterno do céu,

pois é pela tua causa que eu sofro inocente.

De outro modo, que homem (ainda que nascido

da dura pedra) suportaria tais tormentos?

MoçO - Não consigo reter as lágrimas.

Jeremias - Poupa-me, filho; as portas,

quando estão fechadas, não permitem que me vejam as lágrimas.

MoçO - Não consigo aceitar a causa cruel do meu desgosto.

JEREMias - Contém tuas mágoas; poupa este velho miserável;

domina o choro.

Moço - Ó Rei do firmamento dourado,

que com o nascer do sol nos trazes o dia

e em ordem ao descanso estendes sobre a terra a escura noite

com sua sombra errante, presta atenção,

Deus de misericórdia: por momentos e com benevolência, tolera meus queixumes. Se os que guardam escrupulosamente

« Quamquam creatus KCT 2398 Parce] Siste KCT 2399 Videre prohibent quando te clausae fores KCT $\mathbf{2 4 0 0}$ Causam doloris tolero uix duram mei $K C T \mathbf{2 4 0 1}$ Ne tu adde fili plura miserando seni KCT $\mathbf{2 4 0 5}$ nubila $K$ 
Religio curae numen ac ardent tuum, Per utramque ferre solis ardentem domum

2410 Habent amoris praemium nempe hoc sui, Latebram, catenas, carcerem, uirgas, famem, Mercede quis te tam parum laeta colet?

H. Ne tu dolori plura quam iustum est, puer, Concede, moneo. Maxima suorum Deo

2415 Est cura nostro. Qui colit fidus Deum, In utraque fortem sorte se praebet uirum.

Mutentur ipsa tempora, at compos sui Non mutat ipsos propter euentus fidem. Nec Deus acerbis spernit in rebus suos. 2420 Mihi dura quisquis damna molitur, sibi Molitur eadem. Iustus insontem pater A destinatis eripit periculis, Ipsumque damnis punit auctorem suis.

\section{Cvstos Carceris. Pver Hieremiae. Hieremias}

C. Quis me obseratis foribus inuito alloqui

2425 Audacter est aggressus inclusum senem?

P. Me praeter alium non uides.

C. Quis tu?

P. Puer

Nihil unde tumeat animus admisi.

C. Puer!

Puero seniles esse iam possunt doli.

Effare quid uis? Sequeris hunc hominem?

P. Sequor.

2430 C. Sanctum magistrum fata pepererunt tibi.

P. Habuisse talem gaudeo.

\section{Quid ais? Procul}

Custodiae absiste foribus. Quid? Restitas?

Caue.

H. Tumultum quis foris nunc excitat?

C. Responsa custos dura si quaeris dabo.

$\mathbf{2 4 0 8}$ post curae] teque uulgare aestuant KCT $\mathbf{2 4 0 9}$ ferre] nitidi $K C T \mathbf{2 4 1 0}$ amore $K C T$ / nempe -sui] indignum suo $C T$ dignum suo $K \mathbf{2 4 1 2}$ tam $s . u$. / post te] colere tam tristi uolet $K C T \mathbf{2 4 1 3}$ Ne] Nec $K \mathbf{2 4 1 5}$ fidus] uere KCT $\mathbf{2 4 1 6}$ post utraque] fidum sorte se famulum gerit KCT $\mathbf{2 4 1 7}$ Mutentur - tempora] Fortuna uultum mutat KCT/ ac $L \mathbf{2 4 1 8}$ Numquam relinquet asperam ob sortem Deum KCT $\mathbf{2 4 1 9}$ spernet $C T \mathbf{2 4 2 1}$ pater] Deus KCT $\mathbf{2 4 2 2}$ eripit] subleuat 
a santa religião, e se empenham em submeter-se à tua vontade

a toda a hora, do nascer ao pôr-do-sol,

têm uma recompensa destas, a saber,

o isolamento, as cadeias, a prisão, o chicote e a fome,

quem te prestará culto com recompensa tão pouco sedutora?

JEREMIAS - Não faças concessões à dor para lá do razoável,

aconselho-te, meu filho. Em relação aos seus

o nosso Deus tem a maior das preocupações. Quem adora Deus

2415

e lhe é fiel, mostra-se forte em ambas as situações da fortuna.

Alterem-se as circunstâncias mas ele, sem perder a serenidade,

não fará depender sua fé do que acontece.

Nem Deus despreza os seus nos momentos difíceis.

Seja quem for que contra mim arme perigosas ciladas,

é contra si próprio que as arma. O justo Pai

livra o inocente dos perigos que lhe destinaram

e pune com tais ciladas o seu próprio autor.

\section{CENA II: CARCEREIRo, MoçO e JerEmias}

CARCEREIRo - Quem ousou, com as portas fechadas e sem minha autorização, dirigir a palavra ao velho prisioneiro?

Moço - Só me vês a mim.

Carcereiro - Quem és tu?

Moço - O criado dele.

nada fiz que possa irritar alguém.

CARCEReiro - O criado dele!

Num criado podem já existir manhas de velho.

Que queres? Fala. Procuras este homem?

MOÇO - Procuro.

CARCEReiro - Os Fados presentearam-te com um santo mestre.

Moço - Sinto alegria por ter tido um mestre assim.

Carcereiro - Que dizes?

Mantêm-te afastado das portas da prisão. Quê? Recusas?

Toma cuidado.

JEREMIAS - Quem arma agora esse barulho aí fora?

CARCEREIRO - Se queres saber, vou-te responder com dureza, como guarda.

$\longleftarrow \quad K C T \mathbf{2 4 2 3}$ Ipsumque] Ipsum $K \quad \mathbf{2 4 2 4}$ scae. non ind. $C$ / inuicto $K \mathbf{2 4 2 5}$ Est ausus istum perditum et uanum senem? KCT $\mathbf{2 4 2 6}$ om. CVS. KC / post uides] et sum puer KCT $\mathbf{2 4 2 7}$ tumeat] timeat $K /$ admisi] admittam KCT $\mathbf{2 4 2 8}$ post iam] fraudes tibi $K C T \mathbf{2 4 2 9}$ Effare - uis] Possunt abunde $K C$ / P. Sequor] Sat est $K C \mathbf{2 4 3 1}$ gaudeo] non piget $K C$ / Quid ais?] Iubeo $K C \mathbf{2 4 3 2}$ Quid] Adhuc $K C \mathbf{2 4 3 4}$ custos] nequam $K C$ 
2435 Reserabo fida claue ferratas seras.

Age, fraudulenter forte meditaris fugam?

[p. 85]

Aut quid negotii carceris ab imo est tibi?

H. Obicis inepte crimen insolitum fugae.

In uincla non haec nuper ignarus mali

2440 Veni futuri. Sed quid obiectas fugam?

Adeone uinclis me reliquisti leuem

Vt fugere possem? Fugiet haec aetas graui

Onusta ferro? Coeca cur etiam tibi

Calumniandi cupiditas animum tegit?

2445 Iuuenile factum tribuis infirmo seni?

Et innocenti quod facit tantum nocens?

C. Age, mitte uerba. Gradere, si quicquam est tibi,

Coramque fare.

H. Quantus immani rigor

Est in catena, trahere uix corpus sinit.

2450 P. Attonitus hisco, quid uideo? Caelum, mare,

$\mathrm{Tu}$, bruta tellus, sustines tantum nefas?

Est ille praepotentis interpres Dei?

Arcete lucem, lumina tegentes manus.

Me contueri uatis illuuiem pudet.

2455 H. Accede, fili, si catenatum fugis,

Quomodo sequeris?

P. Vt sequar, partem tui

In me laboris transfer.

H. Amplexus cape.

Amoris hi sunt indices.

P. Mallem tuas

Tolerare poenas.

H. Mitte. Me solum premant.

2460 Quamquam malorum non leuem partem damus.

Pars est doloris uelle, quae patior, pati.

C. En ambo. Quid uos? Genitor in gnatum ruit

Et in parentem gnatus. Egregii datis

Documenta amoris. Est aliud?

P. Hoc prandium

2465 Cape. Subleuabit tenue sit quamuis famem.

[p. 86]

H. Remuneretur, nate mi, rerum Sator,

2436 Age - forte] Num fraudulentam uane $K C \mathbf{2 4 3 8}$ ineptae $K \mathbf{2 4 3 9 - 2 4 4 0}$ om. $K C$ $\mathbf{2 4 4 5}$ factum] cur add. $K C$ / infirmo] aegro $K C \mathbf{2 4 4 6}$ quod] quid $K \mathbf{2 4 4 8}$ immane $L \mathbf{2 4 4 9}$ uix trahere $K C \mathbf{2 4 5 4}$ Me contueri] Illam tueri $K C$ / contuere $E \mathbf{2 4 5 5}$ si] me $K C \mathbf{2 4 5 6}$ partem] 
Abrirei os ferrolhos com a velha chave.

Vá, será que pensas fugir traiçoeiramente?

E que te preocupa aí no fundo do cárcere?

JEREMiAs - Lanças-me, sem razão, a insólita acusação de fuga.

Não cheguei há pouco a esta prisão ignorando a desgraça

que me esperava. Mas porque me acusas de querer fugir?

Será que me deixaste tão aliviado de algemas

que até poderia fugir? Fugir com esta idade,

carregado de pesados grilhões? Por que razão também o teu espírito

está possuído da vontade cega de lançar calúnias?

Atribuis criancices a um velho sem forças?

E o que é que num inocente o torna tão perigoso?

CARCEREIRo - Vá, deixa-te de palavras. Aproxima-te, se tens algo a dizer, e fala com franqueza.

JEREMIAS - É tal o rigor

nestas desumanas algemas que mal posso arrastar o corpo.

Moço - Estou de boca aberta. Que vejo eu? Céus, mar

e tu, ó terra bruta, toleras tamanho crime?

É ele o profeta do Deus omnipotente?

Retirai-nos a luz do dia, ó mãos que segurais os astros.

Envergonha-me ver o estado imundo do profeta.

JEREMiAs - Aproxima-te, meu filho. Se me evitas por estar algemado,

como me poderás seguir?

Moço - Para que te siga, transfere para mim

parte do teu sofrimento.

JEREMias - Recebe um abraço meu.

É o sinal do meu amor.

Moço - Preferia suportar

teus sofrimentos.

Jeremias - Deixa. Que me molestem apenas a mim.

Embora dispensemos parte não insignificante dos infortúnios,

querer sofrer o que eu sofro já é uma parte da dor.

CARCEREIRO - Ei-los ambos! Que há entre vós? O pai lança-se nos braços do filho e o filho nos braços do pai. Dais provas

de grande afeição. Há algo mais?

Moço - Toma esta refeição.

Apesar de pouco abundante, aliviar-te-á a fome.

JEREMias - Ó meu filho, recompensar-te-á o Criador do universo,

$\longleftarrow$ pondus $K C \mathbf{2 4 5 8}$ Mallem] Vellem $K C \mathbf{2 4 6 0}$ damus] occupas $K C \mathbf{2 4 6 1}$ quae patior] nobiscum $K C \mathbf{2 4 6 2}$ En - uos?] Bene uos amatis $K C /$ natus in patrem ruit $K \mathbf{2 4 6 4}$ Docmenta $L$ 2465 sit tenue $K C$ / quamuis] quamquam $K C$ 
Cui sancta pietas in calamitosos placet.

In hisce latebris egeo plus quam pauperes,

Qui deprecando publice uictum rogant.

2470 Non ad domandam suppetit egeno sitim

Mihi lympha, qualem patiar hinc disces famem.

P. Ibo per urbem more mendici uagus;

Pulsabo trepida ciuium portas manu.

Alimenta supplex indigo quaeram tibi.

2475 At tu rigorem pone; miserere, obsecro,

Senilis animae. Ne adde poenam uinculis;

Pande redeunti carcerem blandus mihi.

C. Quotiens redieris cum cibo, pandam fores.

Est hominis homini reddere iacenti manus.

2480 H. Tibi miserenti debitas grates ago.

Humanus hominem uir leuas miserabilem.

Redeo in latebram carceris. Praestans puer,

Agenda passu confice citato et redi.

P. Agam.

H. Secundus sospitet euntem Deus.

2485 P. Et te manentem.

C. Carceri obicio seras.

\section{Cvstos CARCERIS, secum}

C. Ego sceleratum rebar hunc olim senem

Iussu imperantis regis obscurissimo

Emancipatum carceri ac dira omnium

Rabie petitum. Namque non poteram satis

2490 Statuere mecum, cur in unius caput,

A rege ad imae sordidam turbam notae,

Crudelis adeo haec esset insultatio.

Ego crimen aliquod rebar horrendum senis.

At ille uultus, illa tranquilli quies,

2495 Patientia et Constantia in tantis malis,

Excusat hominem prohibet et haberi reum.

Aduersa iniquae damna fortunae solent

2469 publice] ad ianuas $K C \mathbf{2 4 7 0}$ Non] Nec KCT 2471 Mi $K$ / post lympha] dura pauperi accessit fames KCT $\mathbf{2 4 7 4}$ supplex indigo] uitae supplici KCT $\mathbf{2 4 7 6}$ post animae] carcerem aperito libens KCT $\mathbf{2 4 7 7}$ om. KCT $\mathbf{2 4 7 9}$ redere $K \mathbf{2 4 8 0}$ Atque misereri. H. Debitas grates ago KCT $\mathbf{2 4 8 1}$ leuat KCT $\mathbf{2 4 8 2}$ Ego me recondo carcere, o praestans puer KCT $\mathbf{2 4 8 3}$ citato] uolucri KCT $\mathbf{2 4 8 4}$ euntem] agentem KCT $\mathbf{2 4 8 5}$ Carceri E1; Carcerem E / C. Carcerem occludo 
a quem agrada a sagrada misericórdia para com os desvalidos.

Nestas cisternas, passo por mais privações

do que os pobres que pedem esmola na via pública.

Não tenho água em quantidade que me mate a sede.

2470

Por aqui avaliarás a fome que suporto.

Moço - Irei vaguear pela cidade como um mendigo;

minhas mãos baterão insistentemente às portas das residências.

De joelhos, pedirei para ti os alimentos de que necessitas.

Mas tu, por favor, põe de lado o rigor, compadece-te

de quem é velho. Não acrescentes mais sofrimento à sua prisão,

e abre-me amigavelmente a porta do cárcere quando eu regressar.

CARCEREIRo - Sempre que voltares com comida abrir-te-ei as portas.

É humano um homem estender as mãos a quem sofre de humilhação.

JEREMIAS - Estou-te profundamente grato pela tua compaixão. 2480

Como pessoa dotada de sentimentos ajudas quem está em situação miserável.

Volto para o meu recanto do cárcere. Excelente rapaz,

não percas tempo; faz o que tens a fazer e regressa.

MoçO - Vou tratar disso.

JEREMIAS - Que Deus proteja quem parte.

MoçO - E a ti, que ficas.

CARcereiro - Vou fechar as portas do cárcere.

\section{CENA III: CARCEREIRo, falando consigo}

Até agora eu tinha este ancião por um criminoso

enviado para esta horrível prisão por ordem do rei

e reclamado pela fúria popular.

A verdade é que eu nunca poderia perceber,

só por mim, por que razão contra a vida duma única pessoa,

desde o rei até à ralé mais desprezível da sociedade,

se haveria de concentrar esta afronta tão cruel.

Pensava num crime horrível cometido pelo velho,

mas aquele semblante, aquela serenidade de pessoa em paz consigo,

a sua paciência e constância no meio de tantos infortúnios

ilibam o homem e não permitem que o consideremos criminoso.

Os revezes da iníqua fortuna costumam pôr a descoberto

— seris KCT $\mathbf{2 4 8 6}$ olim] nimis KCT $\mathbf{2 4 8 7}$ imperantis] potentis $C$ potente $K \mathbf{2 4 9 0}$ Statuere mecum] Noscere, quid esset KCT $\mathbf{2 4 9 2}$ haec esset] fuerit KCT $\mathbf{2 4 9 3}$ Nisi crimen huius aliquod horrendum foret KCT $\mathbf{2 4 9 4}$ illa $^{1-2} E$ / oris elati quies KCT $\mathbf{2 4 9 5}$ Constantia et patientia CTE Constantiam $K \mathbf{2 4 9 7}$ iniquae] rabidae $K C T$ 
Detegere mores. Non mihi plane est nocens,

Tolerantia ingens quem malorum roborat.

2500 Splendore uirtus fulget in tenebris suo

Nubesque lumen nulla uirtutis tegit.

Sed huc superbo graditur incessu tumens

Phassurus animi. Quid agitat secum audiam.

\section{Phassvrvs Dvx. Cvstos}

PH. Stultitia regum quanta uanorum augurum

2505 Aures inani credulas somno dare!

Bene admonebam ne leui uati fidem

Haberet aliquam. Venit Assyrius latro

Similis tonitruo, rediit et par fulguri

Vbi fulminauit nube sub tristi, facem

2510 Reposuit atram. Praeter armorum sonum

Et classicorum murmur ac raucas tubas,

Quid huc Tyrannus attulit? Crede auguri.

I, nunc, et hosti pande murorum fores,

Et dede regem, sceptra, te, patriam, lares.

2515 Et nos Hieremias, patre quo tandem satus,

Qua matre natus, ore terrebat suo?

Quis mentientem si sapit uatem ferat.

Rursus timori ne tamen fieret locus,

Illum putabam morte tollendum semel.

2520 Sed Rex misericors, absque misericordia

Sui et suorum, uiuere necandum sinit.

Viuat, triumphet, carcere effracto euolet

Acturus iterum quam solet tragoediam.

C. Phassure mitra clare, si solui iubes

2525 Custos uocandus non procul praesens adest.

PH. Soluatur. Illum soluit haud uoto meo,

Qui plura regis nomine et sceptro potest

Quam corde sapiat prouido. C. Regem decet

Parcere.

PH. Maleficis?

2501 Nubesque lumen] Vmbra quoque $K /$ eras. nulla ante lumen $\mathbf{2 5 0 2}$ huc superbo] ecce uasto KCT $\mathbf{2 5 0 3}$ agitet $K \mathbf{2 5 0 5}$ somno] sono $K \mathbf{2 5 0 6}$ ad $s . u$. / leui - fidem] fidem uati improbo KCT $\mathbf{2 5 0 7}$ latro] graui KCT $\mathbf{2 5 1 1}$ ac - tubas] admixtum tubis $K C T \mathbf{2 5 1 4}$ eras. scripta s. $u$. sceptra $C$ scepta $K \quad \mathbf{2 5 1 6}$ Qua] Aut $K C T \mathbf{2 5 1 7}$ si sapit] si uir est $C T$ si uis est $K$ 
o carácter das pessoas. Para mim está claro: não é criminoso quem revela tal capacidade para suportar os infortúnios. É no meio das trevas que a virtude revela seu esplendor 2500 e nuvem alguma oculta a luz da virtude.

Mas Fassuro encaminha-se para aqui, com seu andar arrogante e ares de ameaça. Em que pensará ele? Vou estar atento.

\section{CENA IV: Comandante Fassuro e Carcereiro 91}

FAssuro - Que imprudência a dos reis ao acreditarem facilmente nas fantasias vãs dos falsos adivinhos! 2505 Bem lhe recomendava eu que não desse qualquer crédito ao insensato profeta. O ladrão assírio chegou como um trovão e foi-se embora, e no local onde faiscou como um relâmpago, colocou de novo sua negra tocha sob nuvem sinistra. Além do alarido das armas e do som dos clarins e das roucas trombetas, que trouxe para aqui o tirano? Confia no adivinho.

Vá, escancara agora as portas das muralhas ao inimigo e entrega o rei, os ceptros, a tua pessoa, a pátria, seus lares.

E Jeremias (filho de que pai, afinal?

2515

Nascido de que mãe?) aterrorizava-nos com suas palavras?

Quem aceitará um profeta se sabe que ele mente?

Contudo, para não provocar de novo o terror, eu entendia que o deveriam entregar à morte duma vez por todas. Mas o rei, com pena dele mas sem compaixão por si próprio nem pelos seus, permite que viva quem deveria ser morto. Que viva, que triunfe, que se evada, arrombando a prisão, para provocar de novo as tragédias do costume.

CARCEREIro - Ó Fassuro de mitra ilustre, se ordenas que o soltem, não está longe o guarda que deverás chamar. Ei-lo na tua presença. FASSURO - Soltem-no. Não é com a minha concordância que o solta quem, por usar o nome de rei e empunhar o ceptro, é mais poderoso que sensato e dotado de prudência.

CARCEREIRo - Fica bem a um rei

ser indulgente.

$\longleftarrow$ / uatem] placidus? KCT 2518 tamen] tandem $K \mathbf{2 5 1 9}$ Illum - morte] Magum putabam caede KCT 2521 sinit] iubet KCT $\mathbf{2 5 2 2}$ effracto] relicto KC $\mathbf{2 5 2 3}$ Iterum tragoediam ut puto acturus suam KCT $\mathbf{2 5 2 8}$ ante regem eras. CVST. Et C. $s . u$. C $\mathbf{2 5 2 9}$ Malefacis $K /$ ante non eras. CVST. et C. $s . u$. $C$ 
C. Non, sed innocuo seni.

2530 PH. Illene rigorem molliit blanda tuum Oratione?

C. Credo, flexisset tuum.

PH. Mihi iam diu precator esse desiit.

Agnosco penitus quid furens possit senex.

C. Patienter adeo carcerem qui pertulit,

2535 Si uera fari debeo, nondum furit.

PH. Custodis imples munus haud equidem probi.

C. Quae culpa?

PH. Praesens.

C. Indica?

PH. Inimico faues.

C. Cuius inimico?

PH. Me rogas? Dicam: meo.

C. Phassure?

PH. Quid?

C. Seruare delatos reos

2540 Custodis esse credo non odio tuos

Persequi inimicos.

PH. Ira iam gliscit. Caue.

C. Gliscat. Coemptus unde mancipium tibi

Vt commineris?

PH. Pande quas iubeo fores.

C. Obtemperabo quod iubes: munus meum est.

2545 Gratare uates. Prosper aduenio tibi

Nuntius: abire liber a uinclis potes.

H. Quaerenda mentis uera libertas mihi,

Non ista uinclis saepe quae cogi potest.

C. Attende: laeta nuntio; iuberis specu

2550 Ex hoc migrare.

H. Liber?

C. Vt te liberum

Abire mandem, regis imperio obligor.

Regale munus fronte ne tristi cape.

[p. 89]

H. Quis auctor?

PH. Haud ingratus ad sanam modo

2531 Crede KCT 2532 precator] maleficus KCT 2533 Agnosco penitus] Magicusque noui KCT $\mathbf{2 5 3 5}$ debeo] me sinis KCT $\mathbf{2 5 3 6}$ equidem probi] recte datum KCT 2537 Indica] Inuidia $K$ 2538-2539 Cuinam? PH. meo. C. Seruare delatos reos KCT 2541 gliscit] crescit 
FASSURO - Com criminosos?

CARCEREIro - Não, com um velho inofensivo.

FAssuro - Terá ele abrandado o teu rigor com seu discurso sedutor?

CARCEREIRo - Creio que até o teu ele abrandaria.

FAssuro - Para mim, já há muito que deixou de ser um intercessor.

Sei perfeitamente do que pode ser capaz um velho louco.

CARCEREIRO - Quem suportou a prisão tão pacientemente,

se me permitem dizer a verdade, ainda não está louco.

FASSURO - Não desempenhas correctamente a tua função de carcereiro.

CARCEREIro - Faço mal?

FASSURO - Claro.

CARCEReiro - Mostra-me.

FASSURO - Favoreces um inimigo.

CARCEREIro - Inimigo de quem?

FAssuro - Perguntas-me? Dir-to-ei: inimigo meu.

CARCEREIro - Fassuro!

FASSURO - Que há?

CARCEREIRo - Guardar os criminosos

é, penso, a tarefa dum guarda; não perseguir com ódio

2540 inimigos teus.

FAssuro - A minha ira está prestes a explodir. Tem cuidado.

CARCEREIRo - Deixa-a explodir. Onde me compraste como escravo para me ameaçares?

FAssuro - Ordeno-te que abras essas portas.

CARCEReIro - Cumprirei tuas ordens. É o meu dever.

Alegra-te, profeta. Trago-te boas novas:

podes sair em liberdade da prisão.

JEREmiAs - A verdadeira liberdade a procurar é a do espírito, não esta que, com frequência, pode ser constrangida por algemas.

CARCereiro - Presta atenção: tenho boas notícias; há ordens para que saias desta caverna.

JEREMIAS - Em liberdade?

CARCEREIRo - Tenho de deixar

que saias em liberdade. Obrigam-me a isso ordens do rei.

Não acolhas esta dádiva do rei com um rosto triste.

JEREMIAS - Quem deu a ordem?

FAssuro - Não sejas ingrato e admite

$\longleftarrow$ KCT 2542 Gliscat. Coemptus] Decrescat. Emptus KCT $\mathbf{2 5 4 3}$ quas iubeo] iam dico KCT 2544 Obtemperabo, munus ubi poscis meum KCT 2550 eras. abire ante migrare 2551 mandem] sinerem KCT 2552 Regale fronte munus haud tristi accipe KCT 
Redire mentem, pristina a rabie uelis.

2555 H. Contemptor unus o senectutis meae,

O uinculorum causa. Quo tandem meo

Scelere, rotasti perfidae pugnum manus

Et has ferire non refugisti genas?

Adeone minimi cana censetur tibi

2560 Senecta pretii? Verticis canos mei

Nullo pudore tactus euelles?

PH. Caue

Incepta tolli, ne relinquam uincula.

Illum uereri disce, cui uitam dedit

Fortuna casu trahere, quo malit tuam.

2565 H. Age, laute Princeps, adde si quicquam potes.

Certemus uter uincat, aerumnas ego

Tolerando fortis, durus innocuum uirum

Tu persequendo.

PH. Quando Hieremiam exues

Id est, nefandi pariter et fandi senem

2570 Aeque potentem?

H. Quando Phassurum exues

Id est cruentum sanguine innocuo ducem, Si dux uocari qui senem laedit, potest.

PH. Regni uolebam tollere affecti luem.

H. Tibi ergo uiuam certa furioso lues.

2575 Phassure, muta nomen; incensa pauor

In urbe fies. Ille qui uidit suum

In uincla iussu supplicem uestro rapi,

Abrupta uitae fila rescindet tuae.

Moriere, gladio caesus haud sero cades.

2580 PH. O uiperino lingua quam morsu feris!

Cur cesso Manes inferos tali hostia

Ditare? Morere.

C. Ne manus dux imbue

Inermis animae sanguine.

H. Furori impotens

Da frena, pulsa, caede, nodis alliga.

2585 Nam uindicabit ultor insontum Deus.

2555 Contemptor - o] O poena uera tu KCT 2556 O] Et KCT 2560 Senecta (-tae C) nostra, capitis ut canos mei KCT 2561 Pudore nullo tangeres? PH. Ne uincula $K C T \mathbf{2 5 6 2}$ Incepta tolli pigeat ut prudens caue $K C T \mathbf{2 5 6 4}$ malit] uollet $C$ uolet $K \mathbf{2 5 6 5}$ adde] aude $L$ 2567 uirum] senem $K C \quad \mathbf{2 5 6 8}$ exues $E 1$; ex..s $E \quad \mathbf{2 5 6 9}$ senem] uirum $K C T \mathbf{2 5 7 1}$ ducem] 
abandonar tua antiga fúria e retomar o bom senso.

JEREMIAS - Ó desdenhador único da minha velhice; 2555 causa da minha prisão. Que crime foi afinal o meu que te fez usar os punhos de tuas pérfidas mãos, sem evitares ferir as minhas faces?

São assim tão pouco considerados os cabelos brancos

da minha velhice? Arrancá-los-ás de minha cabeça, 2560 tocando-os sem qualquer respeito?

FAssuro - Toma cuidado, não vá deixar como estavam as algemas prestes a serem retiradas. Aprende a recear aquele a quem a fortuna concedeu dar à tua vida o fim que bem quiser.

JEREMIAS - Vá, distinto príncipe, acrescenta algo, se és capaz.

Entremos em despique e vejamos qual de nós vence: se eu, suportando fortes privações; se tu, perseguindo cruelmente um homem inocente.

FAssuro - Quando deixarás de ser Jeremias, ou seja, um velho capaz tanto do crime como da virtude? 2570

Jeremias - E quando deixarás tu de ser Fassuro, ou seja, um chefe cruel de sangue inócuo, se chefe se pode chamar a quem ofende um velho.

FAssuro - Queria evitar a destruição dum reino enfraquecido. JEREMIAS - Pois que eu viva como destruição inevitável para ti, desvairado. Muda de nome, Fassuro; tornar-te-ás o terror 2575 na cidade em chamas. ${ }^{92}$ Aquele que viu o seu suplicante por ordens vossas ser arrastado para a prisão, cortará abruptamente os fios da tua vida.

Morrerás. Não passará muito tempo até caíres morto à espada.

FAssuro - Ó língua, como feres com mordedura viperina.

Porque tardo em brindar os Manes infernais

com tal vítima? Morre.

CARCEREIRo - Não tinjas as mãos com sangue

de vítimas inocentes.

JEREMIAS - Se não dominas teu furor, solta-lhe as rédeas, fere, massacra-me, aperta-me com nós.

A verdade é que o Deus justiceiro vingará o inocente.

« uirum KCT 2572 dux] uir KCT uirum KCT 2573 uolebam] putabam $K$ / tollere] sollere $L$ 2578 rescindit $K \mathbf{2 5 7 9}$ post caesus] occumbes dei KCT 2582 CVS., sustines (sustine $T$ ), ungues imbues $K C T \mathbf{2 5 8 4}$ pulsa] macta $K C T \mathbf{2 5 8 5}$ insontum $C x$; insont.. $C$ 
PH. Aspergo famam non leui scelere meam Quod te diutius perfero horrentem canem.

Age, furialem solus hunc ignem uome.

H. Feriet ab alto quatere qui caelum potest,

2590 Meritisque poenam reddere scelestis parem.

PH. Babylonis armis an sua reddet manu?

H. Quacumque malit impios tollet uia

PH. Euenta rerum si futurarum tenes,

Aperire caelum uoce si clausum potes

2595 Et senta Auerni pallida, ac obnubila

Monstrare terris antra, quaerentem doce:

Quid ille terror oris horrificus tui

Nabucdonosor egerit?

H. Dicam lubens:

Abiit, redibit

PH. Victus in patriam?

H. Tua

2600 Flammis cremata uictor.

PH. Ecquando?

H. Abstine

Demens iocorum. Risus hic acerbior

Felle et aconito fiet, ubi tristem diem

Videris adesse morte supremum tua.

I, dira Regi, dira Princibus cano,

2605 Tibi dira, dira patriae. Adueniet cito

Ferus hostis et uictoria elatus noua,

Nechaone uicto rege Niliacae plagae,

Ingente belli mole terrifici premet

Haec alta pinnis moenia. Euersis cadent

2610 Congesta tectis tecta ; morientur domi

Geminata plebis millia atroce ex lue,

Totidemque ferro concident, totidem fame.

PH. Stultissimus timebo quae falso canis.

H. Stultissimum pugnare cum magno Deo.

2615 PH. Non sum sacerdos? Non ego aethereis Deum

Audio loquentem nubibus? Non pectoris

Arcana saepe consilia pandit sui?

Quid ergo latras? Falsa cur clamas? Tace,

$\mathbf{2 5 8 6}$ scelere] nota $K C T$ scelere non leui $L \quad \mathbf{2 5 8 7}$ perferro $K \mathbf{2 5 8 8}$ uome] quate $K C T$ 2589 Feriet] Quatiet KCT $\mathbf{2 5 9 2}$ impios tollet] ille mactabit KCT $\mathbf{2 5 9 6}$ quaerenti $K C T$ / doce] indica $C T$ indicas $K \mathbf{2 5 9 7}$ horrificus] immensus $K C T \mathbf{2 5 9 8}$ egerit] gesserit $K \mathbf{2 6 0 0}$ Ecquando] 
FAssuro - Mancho minha reputação com um crime nada pequeno, por te suportar tanto tempo como um cão horrível.

Vá, vomita sozinho essas chamas de fúria.

Jeremias - Ferir-te-á Aquele que lá do alto pode abalar os céus

e dar aos criminosos o castigo adequado.

2590

FAssuro - Fá-lo-á com os exércitos de Babilónia ou suas próprias mãos?

JEREMIAS - Seja qual for o meio usado, exterminará os ímpios.

FASSURO - Se conheces os acontecimentos futuros,

se com tuas palavras consegues desvendar os segredos do céu

e mostrar à terra os espinhosos, pálidos e tenebrosos

2595

antros do Averno, diz-me, pois estou curioso:

o que fará esse terror de que falas,

o medonho Nabucodonosor?

JEREMias - Dir-to-ei com todo o gosto:

Retirou-se, mas voltará.

FAssuro - Vencido, de regresso à sua pátria?

JEREMIAS - Vencedor,

com a tua pátria em chamas.

2600

FASSURO - E quando?

Jeremias - Deixa-te de chacotas,

insensato. Esse riso sarcástico de zombaria

ficará mais amargo que o fel e o acónito quando, com tua morte,

vires aproximar-se o dia funesto, o último de tua vida.

Vai, eu profetizo coisas terríveis para o rei, terríveis para os nobres, terríveis para ti, terríveis para a pátria. Chegará, não tarda,

o feroz inimigo e, estimulado com nova vitória,

após a derrota do rei Necao em terras do Nilo,

concentrará o peso da sua terrível máquina de guerra

sobre estas muralhas de elevadas ameias. Ruirão as casas

amontoando-se umas sobre as outras; morrerão em casa,

aos grupos, milhares de pessoas, dizimadas por implacável epidemia,

e sucumbirão outros tantos pela espada e pela fome.

FASSURO - Serei insensato de todo se recear as falsidades por ti apregoadas.

Jeremias - Insensato de todo é lutar com o Deus poderoso.

FAssuro - Não sou sacerdote? Deus falando nas nuvens do céu

não o escuto, porventura, também eu? Os desígnios ocultos

de seu coração não os revela ele com frequência?

Porque ladras então? Porque apregoas falsidades? Cala-te,

« haud pridem KCT 2601 iocorum] iocari KCT 2609 Haec s. u. C / Euersis] aereis KCT 2611 atroce ex] necanti $K C T \mathbf{2 6 1 3}$ Stultissimum est timere quod (quae $T$ ) falso canis $K C T$ 2614 magno] uero $K C T$ 
Fatalis huius urbis et regni timor.

2620 H. Mea dicta ferre si potes, serua memor.

PH. Me larua tristis ire dimissum sines?

H. Audi. Verba meo Deus ore sequentia fatur.

Te pauor e dira rerum nouitate cadentem

Implebit fractosque animis spectabis amicos

2625 Se uelut obiciant gladiis hostilibus ultro.

Hostes caede feri, pecudes ceu ignibus arae

Mactabunt coramque tuos in funera mittent.

Tu membris, tu corde tremens et pallidus ora,

Attonito similis, natorum fata uidebis.

2630 Iamque tuo metuens capiti sine sanguine uultum

Pallentem ostentans, uicina in morte fatisces.

Quin etiam populi et Iudae domus inclita bello

Lapsa cadet. Victis Solymis dominabitur asper

Assyrius. Quanto spumantes sanguine campos

2635 Aspicies atrisque undare cruoribus urbem?

Maiores cum plebe duces, cum rege subacto

Ordinibus uincti longis, Babylona trahentur.

Quicquid habent ciues, quicquid tot saecula reges

Thesauris posuere suis, ferus auferet hostis.

2640 Tuque tuique omnes abducti ergastula nigra

Condita sub tellure coles. Dabis improbe poenas

Squalidus, exul, inops moriere nec ossa repones

In patrio tumulo. Babylon tibi funera bustum

Extruet ignotum, sine pompa et mortis honore.

2645 En tibi quam dederint mentiri oracula laudem.

PH. Habitata sacris adyta Caelitibus poli,

Auditis atrox carmen insani?

H. Audiunt

Satis exequentem imperia mandantis Dei.

Te contumace fronte spernentem uident.

2650 PH. O furia tactus amoue.

H. Amoueo.

PH. Manu

Contaminabor ipse si tangar tua.

H. Tactu sacerdos pollui nostro timet.

Cum uerberabas has truci pugno genas,

2619 timor] lues KCT $\mathbf{2 6 2 1}$ demersum $K \mathbf{2 6 2 2}$ fatur] profert KCT $\mathbf{2 6 2 3}$ e] et $K C T$ $\mathbf{2 6 2 5}$ Se $C x$; Sed $C \mathbf{2 6 2 6}$ pecudem $C T$ / ceu] uelut $K C T$ seu $L \mathbf{2 6 2 8}$ et] tu $L \mathbf{2 6 2 9}$ notorum CT 2637 uincti] uicti in $K$ uincti in add. KCT 2639 eras. gra.i.. af ante ferus 2643 eras. 
agoiro funesto desta cidade e deste reino.

JEREMIAS - Se consegues suportar minhas palavras, fixa-as bem.

FAssuro - Deixas-me ir embora, fantasma sinistro?

JEREmias - Escuta. Pela minha boca Deus fala-te assim: ${ }^{93}$

O pânico perante a surpresa de acontecimentos terríveis

apoderar-se-á de ti, e verás teus amigos, de ânimo esmorecido, como que oferecendo-se voluntariamente às espadas inimigas, e seus adversários, na fúria da chacina, matá-los-ão como vítimas sacrificiais sobre os altares, entregando-os à morte, à vista de toda gente.

Tu, com os membros e o coração a tremer, as faces pálidas, como que assombrado, verás o triste fim dos teus queridos filhos.

E receando já por tua vida, ostentando um rosto pálido, 2630 sem pinta de sangue, ver-te-ás desfalecer face à iminência da morte. Mais ainda: cairá a nobre casa de Judá e sua gente, levados pela guerra. Após a derrota de Jerusalém, reinará o cruel Assírio. Em quanto sangue verás tu os campos espumando e a cidade ondulando em mar de sangue negro? Os nobres e o povo, na companhia do rei cativo, serão arrastados para Babilónia, acorrentados em longas filas. Os haveres dos cidadãos, os tesouros acumulados pelos reis durante séculos, confiscá-los-á implacavelmente o inimigo e tu e todos os teus levados daqui habitarão em negras masmorras, construídas no subsolo. Serás cruelmente castigado.

Morrerás na imundície, exilado e pobre, e teus ossos não terão sepultura em solo pátrio. Babilónia fará o teu funeral, em sepultura anónima, sem pompa nem honras fúnebres.

Eis toda a glória que os oráculos enganosamente te prometeram.

FAssuro - Ó santuários habitados pelos deuses celestes, ouvis o terrível oráculo deste louco?

JEREMiAs - Eles escutam

quem cumpre devidamente as ordens de Deus soberano.

Quanto a ti, eles vêem que tu as desprezas obstinadamente.

FAssuro - Afasta-te, contaminado de fúria.

JEREMIAS - Afasto-me.

FASSURO - Eu próprio

me contaminarei se tuas mãos me tocarem.

JEREMIAS - Um sacerdote receia sujar-se com o nosso contacto.

Quando esbofeteavas estas faces com teus brutais punhos,

$\longleftarrow$ busta, tuisque ante funera / funera bustum] busta, tuisque KCT $\mathbf{2 6 4 4}$ Extruet ignotum] Inferet exequias KCT $\mathbf{2 6 4 7}$ atrox carmen insani] immanissimum. H. Satis KCT $\mathbf{2 6 4 8}$ Satis] Sancta KC 2649 contumaci CT 2651 Contaminabor ipse] Contaminari timeo KCT 
Cur non timebas pollui? O sacrum foris

2655 At intus animi sordidum illuuie sui.

PH. Itane lacessis me sacerdotem Dei?

H. Ita prior arces uinculis uatem Dei?

PH. Non es.

H. Sacerdos ille non etiam mihi,

Cui non Tonantis habeor interpres Dei.

2660 PH. Clara astra iuro, quae uago cursu ambiunt

Aeterna caeli spatia fulgentis; meum

Testor tiara nobile sacrata caput:

Nisi arbitrarer nil senectutem tibi

Fecisse reliquum mentis, his nunc unguibus

2665 In frusta corpus mille lacerassem tuum.

H. Non abnegabo. Vulturem inueni. Mihi

Habeo sepulcrum: uultur hic caesum sua

Recondet aluo. Perge non laetus diu

Nostris fruere uinculis. Disces breui

2670 Carceris opaco sub tenebrosi specu,

Morte grauiorem trahere crudeli diem.

\section{Rex Sedecias. Ivcalvs Dvx. Sophonias Sacerdos}

R. Euenta casu Caelites laeto boni

Dedere nobis prospera. En muri patent,

En hoste nullo cingitur Hebraei decus

2675 Generis auitum Solyma. Crudelem retro

Fortuna pepulit aurea Tyrannum. Metus

Et pallor omnis abiit. Aegypto inclitae

Grates secundae dentur, at primae Deo,

Miserata quando patriae nostrae uicem

2680 Sociique regis, arma pro nobis tulit.

Nec sustinere dubitat Assyrium modo,

Sed prouocare pergit. At congressio et

Regum duorum pugna non cura leui

Distorquet animum. Metuo ne Superi bona

2685 Concessa mutent in repentinam mali

Grauioris iram. Victa si bello cadit

2655 At] Et KCT / sordidum - sui] sordibus spurcum suis KCT 2657 arces uinculis] abdis carcere hunc KCT $\mathbf{2 6 5 8}$ es $C 1$; est $C \mathbf{2 6 6 0}$ quae] qua $L \mathbf{2 6 6 3}$ arbitrarer] reputarem $K C T$ 2664 nunc] hodie KCT 2665 eras. Vnguibus ante In $C 2666$ Bene bene scio uulturem inueni 
não receavas, nessa altura, contaminar-te? Oh! Por fora és venerável, mas por dentro és sórdido, com mente imunda.

FAssuro - É assim que me provocas, a mim, um sacerdote de Deus?

JEREMIAS - É assim que, antes disso, encerras na prisão um profeta de Deus?

FAssuro - Não o és.

JEREMIAS - Também não considero sacerdote

quem não me considera profeta de Deus Omnipotente.

FASSURO - Juro pelos astros cristalinos, que em curso errante vagueiam

pelos espaços infindos do céu brilhante; tomo por testemunha

a minha nobre cabeça com a sua tiara sagrada:

se não tivesse em consideração que tua velhice não deixou em ti

um mínimo de bom senso, com minhas unhas

dilaceraria agora mesmo esse teu corpo em mil pedaços.

JEREMIAS - Não o negarei, encontrei um abutre.

Já tenho sepultura. Este abutre esconderá meu cadáver

em seu ventre. Vai em frente. Não é por muito tempo

que te alegrarás com a nossa prisão. Em breve aprenderás,

no recanto escuro dum tenebroso cárcere,

2670

o que é arrastar vida mais penosa que a morte cruel.

\section{CENA V: Rei Sedecias, Comandante Jucal, SACERdote Sofonias ${ }^{94}$}

REI - Por feliz acaso, os deuses celestes presentearam-nos

com acontecimentos auspiciosos. Vede: as muralhas estão abertas;

não há inimigos a cercar Jerusalém,

a velha glória do povo hebreu. A áurea fortuna

2675

fez retroceder o cruel tirano. O medo

e a palidez desapareceram. Graças sejam dadas

ao nobre Egipto em segundo lugar, mas primeiro a Deus,

pois que, compadecido com a sorte da nossa pátria

e do rei seu aliado, pegou em armas a nosso favor.

2680

E ele não duvida sequer em suster o Assírio,

mas corre a provocá-lo. Porém, o encontro

e o duelo dos dois reis atormenta-me o espírito,

traz-me inquietação. Receio que os deuses

transformem as benesses concedidas em fúria repentina

2685

de desgraça bem pesada. Se o Egipto cair vencido em combate,

$\longleftarrow$ sat est KCT 2667 ante uultur eras. hic mortuum / uultur - sua] mortuum hic uultur sua KCT $\mathbf{2 6 6 9}$ frueris $K \mathbf{2 6 7 2}$ laeta $L \mathbf{2 6 7 9}$ patriae nostrae] gentis Isaciae $C \mathbf{2 6 8 1}$ modum $K$ $\mathbf{2 6 8 2}$ Sed prouocare. Quam tamen sortem feret KCT $\mathbf{2 6 8 3}$ Regnum $K$ 
Aegyptus, omni mole conuertet ferox In me Tyrannus arma. Me miserum, pauet Animus. An aliquo cladis augurio tremit?

2690 SOPH. Agnosce potius numen aeterni patris Quam sit secundum. Parce laetitiam nouo Turbare questu. Tristis abscessum hostium Grauissimorum mente turbata doles?

R. Timendus urget reditus, abscessus leuat.

2695 IVC. Praesente laetus fruere dum fas est bono.

R. At imminente quid decet fieri malo?

IVC. Rex peruetustae clara progenies domus, Columen relictum gentis Hebraeae unicum:

Depelle tristem pectore inuicto metum.

2700 Cur obsequentem te sibi inueniet timor?

Periculorum quisquis imprimis memor

Audendo semper fortia pauori obstitit, felix saluti repperit tandem uiam

Cogens malam parere fortunam sibi.

2705 Sed qui futuros prospicit casus, nimis Metuendo, gelidae dat locum formidini, Vacillat, haeret, trahitur in sortem miser Iniquiorem. Maeret, et numquam sui Animum serenat compos. Imminentium

2710 Cedit malorum cogitando fluctibus

Et ante uentos, et procellas, naufragus

Periturus ipsos urget in scopulos ratem.

SOPH. Sic est timore territus quiuis semel, Si capitur iterum, contremiscit pallidus

2715 Timidumque quotiens horror in pectus redit Morbo laboret ceu caduco, corruit.

Quid si repente cura suspecti mali inuadit animum, qualis est belli citis Formidolosi fama quae pennis uolat, 2720 Quos dat colores? Saepe non hosti cadit Verum timori uictus incerto cadit. Veluti sagittam cerua pennatam timens:

$\mathbf{2 6 8 9}$ An] et $K C T$ / tremens $K \mathbf{2 6 9 0}$ aeterni patris] aeterni Dei $K C T \mathbf{2 6 9 2}$ questu] luctu KCT abcessum KT $\mathbf{2 6 9 3}$ confusa] confusa KCT $\mathbf{2 6 9 6}$ At] Et KCT decet] iubes KCT $\mathbf{2 6 9 7}$ SOPH. pers. KCT 2699 Forti timorem pectore exturba ocyus KCT $\mathbf{2 7 0 0}$ sibi - timor?] metu uano dabis? KCT $\mathbf{2 7 0 1}$ primis E1; primo E / ostio eras. / imprimis memor] in primo ostio KCT $\mathbf{2 7 0 2}$ pauori] timori KCT $\mathbf{2 7 0 3}$ Felicitatis muniit certam uiam KCT $\mathbf{2 7 0 4}$ Cogens malam] Isque docuit KCT $\mathbf{2 7 0 5 - 2 7 2 6}$ Sed qui timendo fecit exangui locum - Formidini, dum 
o tirano, enfurecido, virará contra mim

todo o peso de suas armas. Pobre de mim! Estou apavorado.

Será que tremo com o pressentimento de alguma desgraça?

Sofonias - Admite antes quão favorável poderá ser

2690

o poder do eterno pai. Não perturbes tua alegria

com novos queixumes. Deploras apreensivo,

com o espírito perturbado, a retirada de inimigos tão poderosos?

ReI - Preocupa-me um temível regresso. A retirada deixa-me sossegado.

JuCAL - Goza com alegria as benesses do momento, ${ }^{95}$ enquanto o podes fazer. 2695

Rei - Mas em caso de desgraça iminente, que convirá fazer?

JUCAL - Ó rei, ilustre rebento de antiquíssima família,

único sustentáculo que resta à nação hebreia:

afasta esse receio de teu coração inabalável.

Porque hás-de consentir em dar guarida ao temor?

2700

Todo o que, bem ciente dos perigos,

fez frente ao medo ousando sempre feitos corajosos,

acabou por descobrir, com satisfação, uma saída airosa,

obrigando a fortuna adversa a submeter-se-lhe.

Mas quem, por recear em demasia, vê desgraças no horizonte,

oferece oportunidades ao gélido medo:

vacila e vê-se miseravelmente arrastado

para sorte pior; atormenta-se e nunca serena seu espírito,

senhor de si. Recua imaginando

montes de desgraças prestes a acontecer.

$\mathrm{E}$, perante ventos e tempestades, conduz a embarcação

contra os próprios rochedos, vindo a morrer como náufrago.

SOFONIAS - Assim sucede com qualquer um, assustado uma primeira vez.

Se deixa tomar-se de novo pelo receio, começa a tremer, pálido,

todas as vezes que o terror invade seu tímido coração

e entra em pânico como se sofresse de epilepsia.

E porquê, se de repente a apreensão por suspeita de desgraça

invade o espírito, como a fama rapidamente espalhada

duma guerra terrível, por que razão se fica

com tais cores? Muitas vezes cai-se, não diante do inimigo,

mas perante um vago receio.

Tal como a corça, com medo das flechas:

$\longleftarrow$ pallet, et discit metu - Seruire uilis, cum uolet, fiet graui - Numquam a pauore liber, aut compos sui - Vbi cura damni falsa suspecti ruet. - Suspiciosa fama uel belli ingruet - Victus timori saepe non hosti cadet. - Veluti sagittam cerua pennatam timens - Vbique retur spicula pharetrae horrida - Motae sonare, flabra cum uenti leuis - Diuerberarunt mobiles nemorum comas KCT $\mathbf{2 7 0 7}$ haeret] om. $L$ 
Vbi uentus agitat mobiles nemorum comas,

Sonare pharetram retur et montes fuga

2725 Vallesque anhela praeterit.

R. Ludibria

Non illa mentem uana perturbant meam,

Nec arma frangunt regis Assyrii effera.

Franguntur armis arma, uis ui pellitur.

Sed terret hostis unus e caelo Deus.

2730 SOPH. Non terret, immo facilis et blandus fauet.

Intacta patriae moenia incolumis uides

Et cessit hostis.

R. Cessit, ut redeat mihi

Vobis, Proceribus, his laribus immanior.

Repetentis ictus timeo fortunae alteros.

2735 Et ille curas pectori infigit meo

Vates acerbas pertinax, quamquam sequi

Vestro uoluntas acta consilio fugit.

IVC. Quae tristis adeo Furia tibi regnum inuidet

Pacemque tutae mentis, ut numquam sinat

2740 memoriam abesse tam ueternosi senis?

SОРН. Vno moueris homine? Quid faciunt patres

Quorum tiaris capita sacratis micant

Vmerique niueo carbaso tecti nitent?

Spernuntur? Vno laeta consensu canunt.

2745 At hic repugnans omnibus dira impio

Effundit ore. Sequere tot patres libens.

Errore praestat cadere multorum, sequi

Ne uera dicam monita quam tali duce

Etiam quieto soluere carinam freto.

2750 R. Obstare ueris rebus o quantum est malum,

Videre uero, et credere o quantum bonum.

Regni et salutis publicae in causa decet

Vnum probare, uera si profert, licet

Sexcenta procerum capita diuersum ferant.

2755 Me ferte regem patriae et regno et mihi

Quaerere salutem. Vestra qui totiens tuli

Consilia, fas sit et meum semel dare.

$\mathbf{2 7 2 7}$ Non arma terrent regis inimici fera KCT $\mathbf{2 7 2 9}$ unus e caelo] arce de summa KCT $\mathbf{2 7 3 1}$ incolumis uides] inuictae aspicis KCT $\mathbf{2 7 3 4}$ Ictus reuersae timeo fortunae, alteras $K C T$ 2735 Et] Ille KCT / pectore KCT $\mathbf{2 7 3 6}$ acerbus KCT $\mathbf{2 7 3 7}$ Vestro - acta] Alio uoluntas tracta $K C T \mathbf{2 7 4 3}$ tecti] sancti $K C \mathbf{2 7 4 4}$ Vno E1; Omnes $E$ / concensu $K \mathbf{2 7 5 1}$ uera KCT/ bonum] est bonum KCT $\mathbf{2 7 5 5}$ et mihi] meo KCT $\mathbf{2 7 5 7}$ sit] est KCT $\mathbf{2 7 5 8}$ ardua KCT $\mathbf{2 7 5 9}$ axe] arce 
quando o vento agita a folhagem dos bosques, julga ela escutar o ruído da aljava e, em fuga esbaforida, deixa para trás montes e vales. ${ }^{96}$

REI - Não são vãs

as ilusões que me perturbam o espírito,

nem o abatem os exércitos ferozes do rei assírio.

Os exércitos são derrotados por exércitos; a força é repelida pela força.

Mas é Deus o único inimigo que me assusta lá do céu.

SOFONIAS - Ele não te assusta; antes te favorece, indulgente e compassivo. 2730

Tu contemplas incólume as muralhas intactas de tua pátria.

E o inimigo afastou-se.

REI - Afastou-se, mas pensando regressar mais cruel

contra mim, contra vós, contra os nobres e contra estes lares.

Receio outros golpes da fortuna para me atingir.

E aquele obstinado profeta deixou em meu espírito

profundos receios, ainda que minha vontade,

animada por vossos conselhos, evite deixar levar-se.

JuCAL - Que Fúria agoirenta te inveja tanto o reino

e a paz de teu espírito para nunca permitir

que se apague a lembrança dum velho tão entorpecido?

2740

SOFONIAS - Impressiona-te um simples homem? Que fazem

os anciãos, cujas cabeças reluzem com as sagradas tiaras

e cujos ombros resplandecem, revestidos de fino linho?

São desprezados? São unânimes no anúncio de boas novas.

Mas este, que a todos causa repugnância, fala impiamente

de acontecimentos terríveis. Segue de bom grado tantos anciãos.

É preferível cair no erro de muitos e seguir seus conselhos,

ainda que não verdadeiros, a meter-se num barco à vela

com um timoneiro destes, estando embora o mar sereno.

REI - Como é mau pôr obstáculos à verdade!

Porém, como é bom ver e acreditar!

No interesse do reino e do bem comum convém

dar razão apenas a quem disser a verdade,

ainda que seiscentas cabeças de notáveis pensem diferente.

Permiti-me, como rei da pátria, procurar o bem-estar

para o reino e para mim. Acatei muitas vezes vossos conselhos;

seja-me permitido, por uma vez, seguir uma resolução minha.

$\longleftarrow \quad K C \mathbf{2 7 6 0}$ tua $K C T \mathbf{2 7 6 1}$ suo] ferunt $K \quad \mathbf{2 7 6 3}$... eras. pulsis s. u. C $\mathbf{2 7 6 5} \mathrm{Vt}]$ Quam $K C T /$ ante fieri] faciunt $K \quad \mathbf{2 7 6 7}$ Timide sequentem] Et temperantem $K C T \quad \mathbf{2 7 7 0}$ relabenti] rebellanti $K \quad \mathbf{2 7 7 1}$ praetendit] praetexit KCT $\mathbf{2 7 7 2}$ compositus gradum] si probe intueor $K C T$ $\mathbf{2 7 7 3}$ Benjamina $L$ / eras. sex post se / se mouet porta senex KCT $\mathbf{2 7 7 4}$ Ille, ille uates aggredi actutum $K C T$ / lubet $C T$ iubet $K \mathbf{2 7 7 5}$ Notemus immo dicta quae secum ferat (serat K) $K C T$ 
Adite uatem, quaerite, rogate arduo Quid ab axe mundi uerset in Solymam Deus.

2760 IVC. Parere nostra cura; praecipere est tuum.

\section{IVCALVS. SOPHONIAS}

IVC. Mala mens, sinistra somnia hunc regem suo

Genio timentem in damna transuersum ferunt.

SOPH. Quid ille pulsis hostibus uatem rogat?

Quod carmen optat? Dicta sapientum facit

2765 Vt uera, fieri neminem regem bonum,

Nisi quem malorum cumulus intrepidum uidet,

Timide sequentem blanda Fortunae oscula.

IVC. At iste, raucas ante bellorum tubas,

Decorus armis, alacer ad pugnae aleam,

2770 Poscebat hostem; nunc relabenti cadit

Animo et timori uana praetendit senis

Auguria uatis.

SOPH. Siste compositus gradum

A Beniamaea se senex porta mouet.

IVC. Habemus. Imus, aggredi uatem lubet.

2775 SOPH. Notemus isto quae parat uadens loco.

\section{HiEREMIAS. IVCALVS. SOPHONIAS}

H. Dum parua regni parua ruituri est mora, Visam parentum rura, natalem mei

Terram laboris, huius altricem senis

Ad haec ferenda quae fero, et feram mala.

2780 Postea redibo citior.

IVC. Abscessum parat.

Mandata peragam. Tempus oblatum monet.

SOPH. Vt laeta reddat, ore placato alloquar,

Gressum senilem pauca dum quaero, tene.

Audis, colendi maxime interpres Dei?

2785 H. Quae uox colendum sancta testatur Deum?

Tibi grator uni caelitum ac hominum pater.

$\mathbf{2 7 8 0}$ Post huc redibo properus $K C T \mathbf{2 7 8 1}$ peragi $K C T \mathbf{2 7 8 2}$ reddat] referat $K C T$ $\mathbf{2 7 8 3}$ senile $K \mathbf{2 7 8 4}$ Audis, colendi] Huc o tremendi $K C T \mathbf{2 7 8 5}$ colendum] tremendum $K C T$ 
Ide ter com o profeta, interrogai-o, perguntai-lhe que desígnios prepara Deus para Jerusalém, lá do alto dos céus. JUCAL - A ti compete mandar, a nós obedecer.

\section{CENA VI: JUCAL, SOFONIAS}

JUCAL - Uma mente débil, sonhos agoirentos põem este rei, receoso por natureza, a sonhar com perigos.

SOFONIAS - Porque interroga ele o profeta, quando o inimigo já se retirou? De que oráculos anda à procura? Ele toma por verdadeiras as afirmações dos sábios de que nenhum rei se torna bom a não ser o que é afectado por grande número de desgraças

e permanece intrépido, seguindo timidamente os beijos afáveis da Fortuna. JUCAL - Mas este, diante das roucas trombetas de guerra, equipado com suas armas, desafiava intrepidamente o inimigo para a sorte do combate; agora recua, de ânimo esmorecido, e relembra, temeroso, os falsos presságios do velho profeta.

SOFONIAs - Suspende teus passos.

O velho vai a sair pela porta de Benjamim.

JUCAL - Temo-lo ao nosso alcance. Vamos, agrada-me abordar o profeta.

SOFONIAS - Tomemos nota dos intentos que o movem ao passar neste lugar. 2775

\section{CENA VII: JEREMIAS, JUCAL, SOFONIAS 97}

Jeremias - No pouco tempo que me resta antes da derrocada do reino, vou visitar os campos de meus pais, a terra natal

do meu trabalho, que dá alento a este velho

para suportar estas desgraças que me afligem e afligirão.

Depois, regressarei sem tardar.

JUCAL - Prepara-se para fugir.

Tenho de cumprir ordens. A ocasião recomenda-mo.

SOFONIAS - Falarei em tom calmo, para que me responda bem disposto. Suspende teus passos senis, enquanto te pergunto algumas coisas.

Ouves-me, ó profeta do Deus digno da maior adoração?

JEREMIAs - Que voz abençoada dá testemunho do Deus venerável? Só a Ti dou graças, Pai dos deuses e dos homens; 
Aliquem, colendum praedicet qui te, audio.

Extincta nondum penitus est pietas, suo

Aut a sepulcro uiua patefacto redit.

2790 IVC. Meliora uates gente de nostra sacer

Sperare fas est. Regis huc animum fide

Et sanctitatis luce conspicuum fero.

H. Laetabor, Opifex alme stellantis plagae.

Sperare pacem natus ad bellum iubet.

2795 Sanctum repente nuntiat regem mihi,

Quem nulla flexit ante religio tibi.

SOPH. Mutare saepe se animus humanus solet.

H. Cui talia canis? Forsan ignaro canis,

Qui sensa regis intima agnosco tui

2800 Vestrosque sensus teneo? Num uultu latet

Sub tam modesto fraus, an ingenuae manus

Dare ueritati uultis? Attendo, scio,

Introspicio praecordia. Vt flumen tumet,

Quod concitauit pluuia nimborum asperis

2805 Hiberna furiis, nec suis laetum uadis

Fluenta ripis aucta contectis agit,

Et inundat agros talis abripuit furor

A rege ad imae classis ignotum caput

Omnes habena et nulla praecipites tenet.

2810 Erratis ultra gentium aliarum modum.

Mandata uobis sunt Dei ludibrio.

Iustitia sordet, Veritas, Pietas, Fides

At una tantum bellua est uobis dea,

Libido scelerum certa uestrorum comes.

2815 Abire sinite.

IVC. Gentis o nostrae pater,

Placare si te nequeo, quem finem malis

Vis esse nostris?

H. Nolo quem culpae dabunt.

SOPH. Mitesce, uates, quaeso.

IVC. Dimissis faue.

H. Placate si potestis offensum Deum.

$\mathbf{2 7 8 7}$ colendum] timendum KCT / audio] iuuenis KCT $\mathbf{2 7 8 8}$ eras. penitus ante nondum $K$ / pietas] fides $K \mathbf{2 7 9 0}$ Meliora uates sancte de uulgo impio $K C T \mathbf{2 7 9 1}$ huc animum] imperium $K C T \mathbf{2 7 9 5}$ nuntiant $L \quad \mathbf{2 7 9 8}$ ignaro mihi $m g$. CX / canis] mihi $K C T \quad \mathbf{2 8 0 0}$ Num] Non $L \mathbf{2 8 0 1}$ tam] hoc $K C T$ / An] uel $K \mathbf{2 8 0 4}$ Hiberna furiis pluuia nimborum asperis $K C T$ $\mathbf{2 8 0 5}$ Quod concitauit, nec suis sistens uadis KCT $\mathbf{2 8 0 6}$ contectis] conuulsis KCT $\mathbf{2 8 0 7}$ agris KCT 2809 om. KCT/ Eras, et ante nulla $L \mathbf{2 8 1 0}$ modum] scelus KCT $\mathbf{2 8 1 1}$ Ludibrio mandata 
ouço alguém que Te proclama como digno de adoração.

Ainda não se extinguiu de todo a piedade, ou então ela regressa viva do sepulcro escancarado.

JUCAL - Venerável profeta, é-nos lícito aguardar melhores notícias acerca do nosso povo. Eu trago para aqui o espírito do rei, notável pela sua boa-fé e luz de santidade.

JEREMias - Alegrar-me-ei, venerável Artífice do espaço celeste:

Manda esperar a paz quem nasceu para a guerra.

De repente, anunciam-me como santo um rei

que até hoje nenhum escrúpulo fez curvar diante de Ti.

SOFONIAS - O espírito humano costuma mudar de opinião com frequência.

Jeremias - A quem anuncias isso? Falas, porventura, a um ignorante, eu que conheço os pensamentos íntimos do teu rei

e compreendo os vossos sentimentos? Será que sob rosto tão modesto

2800 não se oculta a mentira? Ou quereis estender as mãos

à verdade autêntica? Eu estou atento, sei, vejo

o que se passa nos corações. Tal como um rio aumenta de caudal, engrossado pelas chuvas do inverno derramadas

por densas nuvens e, não contente com seu leito,

2805

espraia sobre as margens seu caudal volumoso,

inundando os campos, idêntica loucura arrastou todos,

do rei até ao cidadão anónimo da classe mais humilde,

e os mantém cegos, fora de qualquer controle. ${ }^{98}$

Andais no erro mais do que os outros povos.

2810

Os mandamentos de Deus são para vós motivo de zombaria.

Não dais valor algum à Justiça, à Verdade, à Piedade, à Boa-fé.

Vossa única divindade não passa de uma besta monstruosa:

a Sensualidade, companheira certa dos vossos crimes.

Deixai-me ir.

JuCAL - Ó pai do nosso povo,

se não consigo acalmar-te, que fim queres que tenham

as nossas desgraças?

JEREMIAS - Não quero o fim trazido por vossas culpas.

SOFONIAS - Acalma-te, profeta, por favor.

JUCAL - Ajuda quem está aflito.

Jeremias - Se puderdes, desagravai Deus a quem ofendestes.

$\longleftarrow$ sunt uobis Dei KCT $\mathbf{2 8 1 2}$ eras. Sorde ante Iustitia / Sordet animis religio, ueritas, fides KCT $\mathbf{2 8 1 3}$ Iustitia. At una bellua est tantum Dea KCT $\mathbf{2 8 1 4}$ certa] nempe KCT $\mathbf{2 8 1 5}$ o nostrae] Isaciae KCT $\mathbf{2 8 1 7}$ Sed scelera finem uestra terribilem dabunt add. KC [trad. "Mas os vossos crimes farão chegar um fim horrível"] $\mathbf{2 8 1 8}$ Mitesce - quaeso] Placare cur (te CT) nequeo? KCT $\mathbf{2 8 1 9}$ offensum] aeternum KCT 
2820 Me mittite senem.

SOPH. Deseres ciues tuos?

H. Et cur priores uos reliquistis Deum?

IVC. Templi per adyta sancta diuini rogo,

Per huius urbis nomen et auitum decus,

Per illa casto sacra quae cultu pios

2825 Habuere ritus, oro, ne me supplicem,

Neue hunc precantem modo sacerdotem fuge.

H. Oracla fundam scilicet ut iterum meas

Cum rege uoces uester illudat furor?

IVC. Rex ipse supplex orat.

SOPH. Haec quamquam meo

2830 Dicantur ore, Regis esse intellege.

Praesente motus tempore, instanti anxius,

Rex suspicatur esse uiolatum Deum.

Succumbit, orat, eiulat, pronus iacet.

Tu Numen orans redde placatum tuis.

2835 H. Me iusta patriae caritas fractae mouet.

Orare prohibent scelera, quae nullis eunt

Compressa frenis, immo Furiarum inferis

Accensa taedis, a solo in caelum uolant.

At deprecabor. Dum precor supplex duo

2840 Absistite procul. Quicquid oranti Deus

Annuerit, ore libero et aperto loquar.

SOPH. Vtinam secunda reddat e caelo Deus.

\section{Hieremias. OracVlVm}

H. Miserate gentis semper aerumnas tuae,

Obliuiosa memoria quamquam sibi

2845 Benefacta sileat teque despectum suis

Sceleribus hostem faciat ex blando patre,

Tamen parumper respice ac audi preces

Nostras amicus. Das quid in tanto metu

Sperare uel timere? Responsum dabo

2850 His quale dederis. Oro. Si scelerum pudet

$\mathbf{2 8 2 1}$ uos] male KCT $\mathbf{2 8 2 4}$ sacro $C \mathbf{2 8 2 7}$ ante scilicet] Precabor ergo? KCT $\mathbf{2 8 2 8}$ uester] plebis $K C T$ / eludat $C \mathbf{2 8 2 3}$ SOPH. pers. om. / SOPH pers. KCT / Haec] et KCT $\mathbf{2 8 3 0}$ esse intellege] haec uerba accipe KCT $\mathbf{2 8 3 3}$ eiugat $K /$ pronus s. $u$. C1; plorans $C \quad \mathbf{2 8 3 4}$ orans redde] ora et redde $K C T \mathbf{2 8 3 5}$ fracta $K \mathbf{2 8 3 9}$ duo] loco $K C T /$ loco $C x$; loquens $C \quad \mathbf{2 8 4 0}$ 
Deixai em paz este velho.

SOFONIAS - Abandonarás teus concidadãos?

JEREMIAS - E porque abandonastes vós Deus primeiro?

JUCAL - Peço-te, pelos sagrados recintos do templo divino, pela reputação desta cidade e por seu antigo esplendor, pelas cerimónias religiosas que, com seu culto sem mácula, conservaram os piedosos rituais, peço-te, não me abandones, suplico-te, 2825 nem este sacerdote que agora mesmo te dirigia preces.

Jeremias - Proclamarei então oráculos para que de novo

a vossa loucura e o rei zombem de minhas palavras?

JUCAL - É o rei que te suplica.

SOFONIAS - Ainda que seja a minha boca

a pronunciar estas palavras, toma-as como se fossem do rei.

2830

Inquieto com a situação presente, receoso do que possa estar

iminente, o rei desconfia que Deus tenha sido ofendido.

Deixa-se abater, implora, lamenta-se, prostra-se por terra.

Com preces à divindade, reconcilia esta com os teus concidadãos.

JEREMIAS - Comove-me uma justa compaixão pela pátria enfraquecida;

2835

impedem-me de orar os crimes que proliferam

sem freio algum, ou antes, que voam da terra para o céu,

ateados pelas tochas infernais das Fúrias.

Mas implorarei. Enquanto faço minhas súplicas,

mantende-vos ambos afastados. Seja qual for a resposta de Deus

2840

ao meu pedido, dar-vo-la-ei sem reservas e com clareza.

Sofonias - Oxalá Deus te traga boas notícias do Céu.

\section{CENA VIII: JEREMIAS, ORÁCULO99}

JEREMIAs - Tu, que sempre te compadeces dos sofrimentos

de teu povo, ainda que sua falta de memória silencie

os benefícios recebidos e, com seus crimes, te transforme

de brando pai em inimigo desprezado,

pondera contudo um pouco e escuta benévolo

nossas preces. No meio de tanto pânico, que nos dás:

ter esperança ou recear? A resposta que me deres

é a que lhes darei. Se te envergonhas dos crimes,

« Adsistite $K \mathbf{2 8 4 1}$ loquor $C \quad \mathbf{2 8 4 2}$ Secunda reddat ille, quae rogas, Deus $K C T \mathbf{2 8 4 3}$ semper gentis aerumnas $K \mathbf{2 8 4 4}$ sibi] obruat KCT $\mathbf{2 8 4 5}$ ante benefacta] Sibi $K C T$ / sileat $o m$. KCT $\mathbf{2 8 4 7}$ Respice parumper, accipe has timido preces $K C T /$ accipe $s . u$. $C x$; aspice $C \mathbf{2 8 4 8}$ Nostras amicus] Ab ore fusas KCT $\mathbf{2 8 5 0}$ Oro si] rite si $K C T$ 
O misericors placare, da finem malis.

O. Quid magis optarem Solymam quam pace fouere

Et mea tutari uenturis moenia saeclis.

Verum nulla mei reuerentia, nulla pudoris,

2855 Aut aequi iustique manet. Furit acta solutis

Impietas frenis, et fandi oblita, nefandi

Conscia, bella mihi sumptis nouat aspera telis.

Quam multae scelerum facies mea fulmina poscunt,

Et manus abstinuit miserata tricuspide flamma

2860 Hactenus, indulsique locum si forte rebelles

Audirent retroque animos auertere uellent.

H. Terrae, poloque gentis Hebraeae hoc nefas

Notum est abunde. Tuque meministi Pater

Ventura quotiens damna praedixi impios

2865 Si forte traheret a uia scelerum timor.

O. At neque te surdi neque me durata tulerunt

Corda gelu dominum. Leuis irrisoribus augur

Principibus tu uisus, ego somni Deus, ut qui

Terrarum nequeam grauiores sumere cura

2870 Vltricique manu peccantum arcere furorem.

Accipiant ergo, responsa petentibus haec sint

Quae regi mandata ferant. Aegyptia tellus

Nequiquam Solymis fauet auxiliaribus armis.

Frustra quadriiugos trahit in certamina currus.

2875 Namque Paraetonii turmae uix prima tyranni

Proelia miscebunt, primis uix ictibus hostem

Assyrium inuadent, acies aduersa repente

Cum grauis incumbet. Tunc ferreus ingruet imber

Et Babylon iaculis Pharios infiget acutis.

2880 Rex immane fremens Babylonius ante maniplos

Conseret hortator pugnam, uelut eruta rupes

Alto monte cadens procumbet. At hostis et hastae

Impatiens Aegyptus erit signisque relictis

Terga dabit, tutas quaeret fugientibus urbes.

2885 Inde triumphator Solymam rex signa mouebit

Et circum trepidos ponet tentoria muros.

Nec mora terribilis ferro implicitisque tonabit

$\mathbf{2 8 5 2}$ Solymas KCT / fouere] tueri $K \mathbf{2 8 5 3}$ uenturis tutari $K$ / moenia] pergama KCT $\mathbf{2 8 6 1}$ auertere] conuertere KCT $\mathbf{2 8 6 2}$ Terris $K C T /$ hebraeae eras. polo s. u. C $\mathbf{2 8 4 4}$ damna s. $u$. C $\mathbf{2 8 6 7}$ Dominum] scelerum $K C T \mathbf{2 8 7 0}$ peccatum $L \mathbf{2 8 7 1}$ potentibus C patentibus $L$ $\mathbf{2 8 7 3}$ Solymos KCT $\mathbf{2 8 7 4}$ Frustra quadriiugis in curribus emicat ardens $K C T \mathbf{2 8 7 7}$ acies 
acalma-te misericordiosamente; põe fim às nossas desgraças.

ORÁCUlO - Que mais desejaria eu senão favorecer Jerusalém com a paz e conservar através dos séculos as minhas muralhas?

Mas não existe consideração alguma para comigo, para com a virtude ou para com o que é justo e razoável: delira, sem freio algum,

a impiedade e, esquecida da virtude, cúmplice do crime, renova-me guerras cruéis, empunhando armas contra mim.

Inúmeros e variados crimes estão pedindo os meus raios, e minhas mãos misericordiosas abstiveram-se da chama de três pontas até hoje. Dei oportunidade aos rebeldes de me escutarem e de se disporem a alterar seu comportamento.

JEREMIAS - Na terra e no céu esta impiedade do povo hebreu é bem conhecida. E tu lembras-te, Pai, quantas vezes anunciei castigos que chegariam se o medo não desviasse os ímpios da estrada do crime. ORÁCUlo - Mas, surdos, não te aceitaram, nem a ti nem a mim, como seu senhor, corações de gelo empedernido. Foste ridicularizado pelos príncipes, tu, como um vulgar adivinho; eu, como um Deus sonolento, incapaz de assumir as tarefas mais exigentes da terra e de, com mão justiceira, conter o ímpeto dos prevaricadores. 2870 Fiquem, pois, os poderosos a saber as respostas que obtive para as transmitirem ao rei como ordens: é em vão que o Egipto apoia Jerusalém com tropas auxiliares; é em vão que ele traz para o combate suas quadrigas. Porque dificilmente os esquadrões do tirano paretónio aguentarão 2875 o início dos combates; dificilmente avançarão sobre o inimigo assírio nas primeiras investidas, quando a vanguarda inimiga investir repentinamente com forte ímpeto. Abater-se-á então sobre eles uma chuva de ferro e Babilónia cravará nos Egípcios seus dardos aguçados.

Soltando brados horríveis à frente de seus estandartes, o rei de Babilónia 2880 combaterá e instigará ao combate, como se uma rocha solta rolasse caindo montanha abaixo. Mas o Egipto não conseguirá suster nem o inimigo nem suas lanças e, abandonando os estandartes, virar-lhe-á costas e procurará cidades seguras para os fugitivos. Então o rei triunfante fará deslocar suas tropas para Jerusalém e assentará tendas em torno das muralhas assustadas.

E sem esperas angustiantes, ouvir-se-á o som das espadas

$\longleftarrow$ aduersa] acie dum (cum $T$ ) dira KCT $\mathbf{2 8 7 8}$ Telorum seges hostili et grauis ingruit imber KCT 2879 om. KCT $\mathbf{2 8 8 2}$ eras. Monte ante Alto / Monte cadens summo procumbet, et hostis et hastae $K C T \mathbf{2 8 8 4}$ Terga (Targa $K$ ) dabit iaculis terebranda sequacibus, inde $K C T \mathbf{2 8 8 5}$ Plena triumphator Solymam uexilla mouebit KCT $\mathbf{2 8 8 6} \mathrm{Et}$ ] Ac KCT / ponet] figet KCT 
Arietibus, scandet legio Babylonia muros

Et tandem ciues Solymas ardere uidebunt.

2890 H. Proceres feroces bella, non pacem, rogant.

o. Bella dabo, uires sed quae sine numine nostro?

Ite, licet. Capite arma manu contraria quamuis

Agmina caedantur, paucis modo uita supersit

Chaldaeis, illi manibus funalia tollent,

2895 Et numero pauci tradent hanc ignibus urbem.

H. Abis minister Ales o praepes Dei,

Et nil amicum, lene, pacatum refers?

O Solyma Solyma qualis est sortis tuae

Funesta ratio? Nil opis praebet Deus.

2900 SOPH. Quam tristis ore pallido et maesto redit.

H. Quamquam loquatur axe de supero Deus

Regemque clara uoce praemoneat, fuge

Fuge fulmen, inquam, fulmen incandens manu,

Quod iam rubente uibro, nil stolidus magis

2905 Sese mouebit tacta quam radiis iuga

Trifidis recedunt. Venio, sed uenio grauis

Durusque regi nuntius. Cladem antea

Vnam timebat pauidus; agnoscat duas.

Aegyptiorum gente deleta, potens

2910 Nabucdonosor aduolat. Regi haec meo

Referte dicta nomine, aut potius Dei.

SOPH. Referentur. At sunt grauia.

H. Facinoribus tamen

Adhuc minora. Parua dum restat mora

Iuuat Anathotum adire natale oppidum.

IERIAS, custos portae Beniamaeae, HiEREMIAM capit

2915 IE. Quis ille? Vigilem fallere haud hodie potes?

Es noster ore ciuis ast animo impio

Factus inimicus patriam prodis tuam.

Transfuga, domestice latro, praedo, proditor

Chaldaea quare castra discedens petis?

$\mathbf{2 8 8 8}$ post scandet] paulatim machyna pinnas KCT $\mathbf{2 8 8 9}$ Et tandem Solymas ardere uidebitis arces KCT $\mathbf{2 8 9 0}$ Proceres] Solymi KCT $\mathbf{2 8 9 2}$ post manu] Babylonia quamuis KCT $\mathbf{2 8 9 3}$ paucis] tumidis $K \mathbf{2 8 9 5}$ Hanc pauci, solique absument ignibus urbem KCT $\mathbf{2 8 9 6}$ Abis - o] Magni (Magne $K$ ) recedis Aliger KCT 2897 nihil $K$ / placatum KCT 2903 Fuge fulmen, 
e dos recurvos aríetes; os exércitos de Babilónia escalarão as muralhas

e os cidadãos verão, finalmente, Jerusalém em chamas. ${ }^{100}$

JEREMIAS - Os notáveis do reino insistem na guerra, não na paz.

ORÁCUlo - Dar-lhes-ei guerras, mas que forças terão eles sem o nosso poder?

Mas podeis avançar, empunhar armas; ainda que os batalhões inimigos sejam massacrados e restem com vida poucos Caldeus,

estes mesmos tomarão em suas mãos archotes

e, mesmo em reduzido número, entregarão às chamas esta cidade. ${ }^{101}$

2895

JEREMIAs - Retiras-te, mensageiro alado de Deus?

Nada referes de amistoso, de agradável, de tranquilizador?

Ó Jerusalém, Jerusalém, qual é a razão

de teu funesto destino? Deus não te presta auxílio algum.

Sofonias - Como volta triste, de semblante pálido e choroso!

2900

Jeremias - Embora Deus fale do alto dos Céus

e previna o rei em termos claros dizendo-lhe

"foge, foge do raio incandescente

que minha dextra agita fremente", o insensato não se moverá

mais do que recuam os cimos dos montes quando atingidos

2905

por raios de três pontas. Eu venho, mas venho como mensageiro

desagradável e duro para com o rei. Até aqui ele receava

uma desgraça apenas; pois há-de conhecer duas.

Aniquilada a nação egípcia, o poderoso Nabucodonosor

aproxima-se rapidamente. Em meu nome, ou antes,

2910

em nome de Deus, transmite ao rei estas palavras.

Sofonias - Transmiti-las-ei, mas são desagradáveis.

JEREMias - Contudo, são-no ainda menos

que os crimes. Enquanto disponho de algum tempo,

agrada-me ir até à minha cidade natal de Anatoth. ${ }^{102}$

CENA IX: JERIAS, guarda da porta de Benjamim, prende JEREMIAS 103

JERIAs - Quem é aquele? Não é hoje que conseguirás iludir a sentinela. 2915

Pelo aspecto, és um dos nossos, mas tornaste-te inimigo

traindo sacrilegamente tua pátria.

Desertor, ladrão de casa, salteador, traidor.

Porque te afastas na direcção dos acampamentos caldeus?

$\longleftarrow$ inquam] Caeli fragorem, ac $K C T$ / in candens $L \mathbf{2 9 0 5}$

eras. flammis $m g$. C / radiis] flammis KCT $\mathbf{2 9 0 6}$ Creperis recedunt. Redeo sed redeo grauis KCT $\mathbf{2 9 0 8}$ eras. ... post Vnam / pallidus KCT 2916 Est $C$ / orae $K$ / ast] es $K$ 
2920 H. Egone relictis transfugio ad hostem meis?

IE. Detecta fraus est; desine infandum scelus

Ambagibus negare. Vos, funes date.

Adeste fidi milites, loris senem

Vincite. Nodis implicate transfugam.

2925 H. Itane trahetur innocens mendacio?

IE. Agite fideles, adligate milites.

H. Aeterne Iudex, opprimi insontem uides?

IE. Oculis carebit si innocentem te uidet.

Adigite. Causa Principum arbitrio, tua

2930 Definietur. Nemo se insontem docet

Me postulante, qui capessentem fugam

Modo comprehendi.

H. Falsa cur coeco struis

Animo nocendi?

IE. Principes, Proceres, Duces

Patres coite transfugae in dirum caput.

2935 Cepi petentem castra Chaldaea hunc senem.

\section{Phassvrvs. Hieremias. Saphatias. Godolias}

PH. Ex scelere laberis in nouum rursus scelus, O una regni furia. Dic, nuper tibi est Miserante Rege uita concessa, ut foret Priore peius crimen audendum? Taces?

2940 Effare? Lingua muta nunc primum est tibi?

Sed cur rogamus? Trahite lictores mei

Flagra expedite, terga detegite ocyus

Lacerate corpus. Debet hanc poenam mihi.

H. Quod crimen ista lege puniri solet?

2945 Delator est mentitus et capto locum

Defensionis subtrahis. Quae tempora,

Quae iura, quae iudicia quae leges?

Vos agite uirgis plectite.

GOD. Sile.

\section{H. Adflicto parens}

Occurre uati, uindica insontem Deus.

2921 Detecta] Aperta KCT / nefandum KCT 2925 Mendacio circumuenior homo innocens KCT 2928 Oculis carebit] Non ille cernit KCT 2930 Definietur innocens an sis reus KCT 2932 Modo] Te KCT 2933 Proceres] magni KCT 2935 Coepi $L 2937$ una] dira KCT / dic] 
JEREMIAS - Eu passar-me para o inimigo, abandonando os meus?

2920

JERIAS - Descobriu-se o embuste; pára de negar com rodeios

esse crime abominável. Vós, trazei-me cordas.

Vinde cá, soldados fiéis, amarrai o velho com correias;

apertai o desertor com nós.

JEREMIAS - É assim que pela mentira se levará à força um inocente?

2925

JERIAS - Vamos, soldados fiéis, amarrem-no.

JEREMIAS - Ó Eterno Juiz, não vês que oprimem um inocente?

JERIAS - Terá falta de visão se te vir como um inocente.

Levai-o. Os nobres ajuizarão sobre a tua causa.

Ninguém dirá ser inocente,

quando o levar a tribunal, quem acabei de apanhar

procurando fugir.

Jeremias - Porque arquitectas falsidades

tentando prejudicar-me?

JERIAS - Príncipes, próceres, generais,

anciãos, reuni-vos em redor da sinistra figura deste desertor.

Eu surpreendi este velho a encaminhar-se para os acampamentos caldeus.

2935

\section{CENA X: Fassuro, Jeremias, Safatias, Godolias}

FAssuro - De novo resvalas dum crime para outro,

ó Fúria sem par do reino! Diz-me: concederam-te há pouco

a vida, graças à compaixão do rei, para ousares

novo crime, pior do que o anterior? Calas-te?

Fala! Pela primeira vez fica muda a tua língua.

2940

Mas porque insistimos? Arrastai-o, guardas;

preparai azorragues; ponde-lhe já as costas a descoberto;

vergastai-lhe o corpo. Eis o castigo que ele me estava a dever.

JEREMIAs - Que crime é habitual punir nestas condições?

Um delator mentiu-te e tu retiras ao prisioneiro

a possibilidade de se defender. Quais foram as circunstâncias, os motivos, os julgamentos, as leis?

Godolias - Cala-te.

Vamos, açoitem-no com vergastas.

JEREMIAS - Socorre, Deus Pai,

um profeta em aflição; vinga um inocente.

« num KCT 2938 at] $L \mathbf{2 9 3 9}$ Peiore $C \mathbf{2 9 4 0}$ Armata quondam fraudibus auerni impiis add. KCT [trad. "... que dantes surgia armadilhada com os impios embustes do Averno."] 2944 lege] legi $E \mathbf{2 9 4 5}$ capto] misero KCT $\mathbf{2 9 4 9}$ uati] iudex KCT 
2950 SAPH. Iubete, sileat. Discat imperium pati.

Propellite scelestum. Abditote ergastulo

Tenebricoso. Carcerem Ionathae date.

Seruate, ne labatur.

H. Immane o scelus.

PH. I, querere sub silente poenarum lacu.

[p.103]

\section{NVNTIVs aduentantis Nabucdonosoris. GEDELIAS}

2955 N. Quicumque regni nobilem Isacii cupit

Arcem tueri, scandat in murum, sua

Depromat arma. Turbo ceu praeceps ruit

Sternensque lucos, nemore dat toto sonum,

Aut flamma siluam qualis ardentem uorat,

2960 Talis superbo properat incessu tumens

Nabucdonosor. Proelio uicta occidit

Aegyptus. Vrget uictor, a tergo alitem

Ostentat aciem, signa non absunt procul.

GED. Quae turba? Quae uox?

N. Euola, portas iube

2965 Custode cingi, classicum bello cane.

Aduentat hostis uictor. Aegyptum graui

Plaga cecidit.

GED. Milites fidi mei,

Ad arma properi ruite. Da praeco sonum.

Infla canoram uoce terrifica tubam.

2970 Subite mecum, scandite in murum, uiri.

Tenete rapta tela bellanti manu.

Defendite lares patriae, leges, sacra

Paruosque natos. Eia, quae iussis mora?

PR. Praecipitate moram. Toto ruit agmine uictor

2975 Hostis. Ab Aegypto Babylon uenit horrida uicta.

Cingite compositis trepidantia moenia turmis

Et pugnam Isacii pro gente capessite regni.

2951 Abdite $K C$ abdito $T$ / post abditote] hunc add. KCT 2952 date] incolat $K C T$ 2953 labatur] diffugiat $K C T$ / O dirum scelus $K C T \mathbf{2 9 5 4}$ querere] sequere $K \mathbf{2 9 5 7}$ Depromat] Capessat KCT 2959 Omnisque foliis arbor ambustis crepat add. KCT [trad.: "...e cada árvore crepita, com a folbagem a arder."] $\mathbf{2 9 6 0}$ properat] graditur KCT/ incensu $C \mathbf{2 9 6 1}$ excidit KCT 
SAFATIAs - Obriguem-no a calar-se. Há-de aprender a submeter-se.

2950

Levem daqui esse desgraçado. Encerrem-no em tenebrosa prisão.

Mandem-no para o cárcere de Jónatas. ${ }^{104}$ Tende cuidado,

não vá ele conseguir fugir.

JEREMIAS - Ó crime horrendo!

FAssuro - Vá, queixa-te no lago silencioso dos tormentos.

CENA XI: MENSAgEIRo anunciando a chegada de Nabucodonosor. Gedelias

Mensageiro - Todos os que desejam defender a nobre cidadela 2955 do reino de Isaac, subam às muralhas, empunhem suas armas. Como tempestade que se arma de repente e, derrubando árvores, faz ressoar todo o bosque, ou como o fogo que envolve a floresta em chamas, ${ }^{105}$ assim avança Nabucodonosor, com seu passo arrogante, 2960 fremente de raiva. O Egipto caiu vencido em combate.

O vencedor ameaça-nos, vem no nosso encalço com uma vanguarda rápida. Os estandartes não estão longe.

Gedelias - Que agitação, que vozes são estas?

Mensageiro - Corre; dá ordens;

reforcem as portas com guardas; faz ressoar os clarins de guerra.

2965

O inimigo aproxima-se vitorioso; pesada derrota

foi infligida ao Egipto.

Gedelias - Meus caros soldados, pegai rapidamente em armas; arauto, dá o sinal;

sopra na melodiosa trombeta de som assustador; avançai comigo, soldados; subi às muralhas;

não largueis das mãos as armas que empunhais com coragem.

Defendei os lares da vossa pátria, suas leis, seu culto

e suas crianças. Vamos, por que esperais?

Arauto - Apressai-vos. O inimigo irrompe vitorioso com todo o exército.

Babilónia regressa terrível após ter vencido o Egipto.

2975

Rodeai com tropa disciplinada as muralhas trepidantes

e combatei pela nação do reino de Isaac.

« 2964 R. pers. $K$ / Euola] et add. KCT 2965 classico bellum KCT 2967 GED. pers. om. $K$ / fidi] duces $K T \mathbf{2 9 6 8}$ propere $K \mathbf{2 9 7 0}$ Mecum subite $K C T$ / muros KC $\mathbf{2 9 7 5}$ Victor ab Aegypto rediens impune tyrannus KCT $\mathbf{2 9 7 6}$ moenia] pergama KCT $\mathbf{2 9 7 7}$ capescite $L$ 


\section{Clamor Militum urbanorum discurrentium}

Ferte citi ferrum, date tela, ascendite murum.

Non procul apparent uenientia signa Tyranni.

2980 Iam litui clangunt auditaque cornua raucum

Dant sonitum, glomerataque personat ungula plausu.

\section{PrimVM AGMEN NABVCDONOSORIS. NABVSARDANVS}

NABVZ. Victori reserate fores, bipatentibus hostem

Accipite Assyrium portis. Age, pandite muros

Bis capti Solymi, bis serui ob foedera rupta,

2985 Tertia uictoris domini tolerabitis arma.

Impatiens gens ferre iugum, nec robore firmo

Apta sua ferrum pro libertate tenere.

Quod tibi quadriiugis Aegyptus barbara carris

Attulit auxilium? Captiuam hanc aspice turbam

2990 Et capita arrectis affert quae miles in hastis.

\section{OPPIDANI ex muro}

OP. Si cecidit Nechao, Solymae stat nobile sceptrum.

Stant muri, stat lecta manus, quae uincet, in ipsa

Aut acie moriens animam prius auferet hosti.

NABVC. Aegyptus armis ausa sceleratis meam

2995 Potentiam est tentare? Nec peperit metum

Diuinitatis sola maiestas meae?

Certare potuit? Ora Chaldaeae pati

Horrenda gentis potuit? O amentiam!

Et pro rebelli Rege pugnauit, mea

3000 Quem dextra Regem fecit, et iussi inclitum

Paterna Solymis iura foedifragis dare.

Quam iustus ille Rector aurati est poli,

Quicumque mundum lege perpetua regit,

Meritis adaequat praemia, et poenam irrogat

3005 Iustam nocenti. Bella Sedecias mihi

Molitus animo perfido, Aegyptum quoque

Fecit inimicam. Cecidit Aegyptus. Cadat

[p. 105]

2978 scandite $L /$ muros] ciues $C T$ muros eras. et ciues $s . u$. $K \mathbf{2 9 7 9}$ Non procul assyrii apparent uexilla tyranni KCT 2980 Iam] En $K C T 2987$ sua $L \mathbf{2 9 8 8}$ Quid $K \quad \mathbf{2 9 9 0 - 9 3 ~ o m . ~}$ 
ClAMOR DE SOLDADOS, movimentando-se na cidade em várias direcções

Pegai rapidamente em armas; lançai dardos, subi às muralhas.

Já se vêem, muito perto, os estandartes do tirano;

já ressoam os clarins e as trombetas fazem ouvir seu som estridente. 2980

Ecoa no ar o som compacto dos cascos dos cavalos. ${ }^{106}$

CENA XII: VANGUARDA DO EXÉRCITO. NABUZARDANO. ${ }^{107}$

NABUZARDANO - Abri caminho ao vencedor; recebei o inimigo assírio de portas abertas. Vamos, franqueai as muralhas.

Jerusalém, duas vezes ocupada e escravizada por romper alianças, suportarás terceira vez os exércitos vitoriosos do nosso soberano.

Gente incapaz de suportar o jugo, sem jeito e forças

para empunhar a espada em prol da liberdade.

O bárbaro Egipto com suas quadrigas

que auxílio te trouxe? Repara nesta multidão de prisioneiros

e nas cabeças que os soldados seguram na ponta de suas lanças.

2985

\section{CIDADÃos, do alto da muralha}

CidADÃos - Se Necao caiu vencido, subsiste o nobre ceptro de Jerusalém, subsistem as muralhas, subsiste a tropa de elite que, se não vencer, morrerá na frente de batalha, após tirar a vida ao inimigo.

NABuCODONOSOR - O Egipto ousou desafiar meu poderio

com seus infames exércitos? Nem sequer lhe inspirou receio

2995

a majestade da minha divina pessoa?

Foi capaz de combater? Os rostos temíveis do povo caldeu

atreveu-se ele a enfrentar? Oh! Que loucura!

E lutou a favor dum rei rebelde que minha dextra

colocou no trono e a quem ordenei que aplicasse as leis de seus pais

3000

sobre os habitantes de Jerusalém, violadores de alianças.

Como é justo Aquele que rege o firmamento estrelado,

seja quem for, que governa o mundo com leis imutáveis,

que adequa a recompensa ao mérito e, aos culpados

dá o castigo devido. Sedecias, ao mover-me guerra

3005

com espírito traiçoeiro, tornou o Egipto

igualmente meu inimigo. O Egipto caiu vencido.

« KCT 3000 et] ego KCT $\mathbf{3 0 0 1}$ iura eras. $K \mathbf{3 0 0 2}$ poli est $K$ 
Vt nunc tyrannus iste, quem captum mei

Vbi iuris esse uidero, docebo fide

3010 Qua sunt tuenda foedera. Hos claros duces

Captiua capita cernere Aegypti lubet.

Ea decolorat pallor. At nondum suo

Cumulo est uoluptas. Forsan implebit cito

Pharao reuinctus. Tuta non semper fuga est.

3015 Vrbem hanc potenti diruam captam manu.

Delebo flammis culmina domorum ardua,

Incendio decora templi limina;

Adytis cremabo dirutis sacraria.

Ego in parentum sanguine extinguam genus

3020 Et enecabo liberos. Patrum bibant

Nati cruorem, caede natorum patres

Madeant cruenti. Squaleant tabo uiae.

Tollere ita gentem perfidam est datum mihi.

Age, tu secundas cui dedi partes, uide

3025 Qua parte miles aggredi muros queat.

NABVZ. Curabo, uictor orbis. Haud sero tuum

Votum morabor. Agmine silenti modo

Iube locari castra qua muri patent

Depressiores. Inde non magno potest

3030 Labore Solyma militis nostri capi.

NABVC. Sequatur acies. Aere da signum, moue.

\section{Clamor, ex urbis moenibus}

Quo properant hostes, speculis aduertite ciues.

Signa mouent. Castrisne locum sedemue requirunt?

An fugiunt pugnaeque piget? Tentoria figunt.

3035 Et fortasse parant nos obsidione tenere.

Ne trepidate, uiri. Virtus Solymaea reuerti

Indecores hostes et signa refigere coget.

\section{Rex Sedecias. Hieremias}

R. Belli tremendi quanta tempestas quatit

3010 sunt] sint KCT 3011 lubet] iuuat $K \mathbf{3 0 1 2}$ Quos dant colores. Plena sed nondum suo KCT/ in om. E $\mathbf{3 0 1 5}$ hanc om. KCT / captam] euersam KCT $\mathbf{3 0 1 6}$ ardui $L \mathbf{3 0 1 8}$ Aditisque penetralia cremabo dirutis KCT $\mathbf{3 0 1 9}$ post parentum] undante opprimam $K C T \mathbf{3 0 2 1}$ caedi $C$ 3022 Madeant] Fiant KCT 3023 perfidam] perditam KCT 3025 miles] muros KCT / post 
Caia agora este tirano a quem, uma vez em minhas mãos

e sob minhas leis, eu ensinarei com que lealdade

se deverão respeitar as alianças. Agrada-me ver

3010

estes ilustres generais do Egipto feitos prisioneiros.

A palidez altera-lhes a cor. Mas meu prazer

ainda não chegou ao auge. Talvez lá chegue depressa

com a prisão do faraó. Nem sempre a fuga é bem sucedida.

Quanto a esta cidade, arrasá-la-ei sem piedade após a conquistar.

3015

Pegarei fogo aos seus grandiosos edifícios; as belas fachadas

de seu elevado templo serão pasto das chamas;

destruídos os santuários, reduzirei a cinzas seus redutos mais sagrados.

Farei desaparecer esta raça no sangue dos pais

e matar-lhe-ei os filhos. As crianças beberão

3020

sangue dos pais e com o sangue dos filhos

ficarão os pais manchados. Corpos putrefactos sujarão os caminhos.

Assim me foi concedido exterminar este povo traiçoeiro.

Vá, tu, a quem nomeei meu adjunto, vê

por onde poderão os soldados lançar o ataque às muralhas.

3025

NABUZARDANo - Cuidarei disso, vencedor do universo. Não farei

tardar teus desejos. Ordena que, silenciosamente,

um esquadrão instale já acampamentos na zona em que as muralhas se apresentam mais baixas. Daí, sem grande esforço,

será possível aos nossos soldados tomar de assalto Jerusalém.

NABUCODONOSOR - Que o exército te siga. Dá sinal com a trombeta. Marcha.

\section{Clamor vindo das muralhas}

Que direcção toma o inimigo? Observai das guaritas, cidadãos.

Os estandartes movimentam-se. Procuram local apto para acampar?

Ou fogem, sem vontade de combater? Eles assentam tendas

e talvez se preparem para nos cercar.

3035

Não vos assusteis, soldados. A coragem de Jerusalém forçará

o inimigo a recuar ingloriamente e a levantar de novo os estandartes.

\section{CENA XIII: Rei Sedecias, Jeremias 108}

REI - Grande perturbação me abala o espírito assustado

— aggredi] excelsos queam KCT $\mathbf{3 0 2 6}$ uictor] ductor KCT $\mathbf{3 0 2 8}$ Iubeas KCT $\mathbf{3 0 3 0}$ Labore nostro ciuitas tandem capi KCT Labore nostri militis Solyma capi $E \mathbf{3 0 3 1}$ acies] agmen $K C T /$ dat $K$ 3032 spiculis $K \quad \mathbf{3 0 3 5}-\mathbf{3 0 3 7}$ om. KCT 
Animum pauentem. Quo trahor? Faciles uiam

3040 Aperite Diui. Estote propitii mihi.

Diro obsidemur hoste. Praesidium foris

Nullum fugato Rege Niliaco manet.

Domesticae sunt impares hosti manus.

Quo te remittis anime? Quem uatem rogas?

3045 Vnus Hieremias uera quam semper mihi

Pronuntiauit. Vate quo potui grauem

Belli procellam fugere, si ueri tenax

Ego maluissem certa pro falsis sequi.

Agnosco quid sit regia potestas; malis

3050 Circumuenimur fraudibus, mendaciis

Aulam patentem saepe non cauti damus.

Sed sapere liceat, semper erranti, semel.

Adibo supplex, consulam inclusum senem.

Reserate portas: prodeat uates foras.

3055 Secedite procul. Nemo sit testis. Volo

Vatem remotis arbitriis mecum loqui.

H. Regnator, oculos pascit hic squalor tuos?

Satisne poenas hoc damus cultu tibi?

An duriora ad supplicia uinctum trahis?

3060 R. Inuitus equidem cerno nec leuiter meos

Offendit oculos corporis squalor tui.

H. Leuare dura uincla, si doles, iube.

R. Iubebo. Voces placidus ausculta meas.

Inimica patriam castra uallatam tenent.

3065 Auersa monstrat ora si nobis Deus,

Posita nec ira supplicem regem uidet,

Populumque uictum tot malis, restat mori.

H. Voce has querelas flebili narras mihi?

R. Tibi quis alter fauerit uel feruidum

3070 Quis alter ira flectere Tonantem potest?

H. Qui falsa nuper carmina superbi dabant,

Credente rege, qui meas durus preces

Numquam serenis uoluit audire auribus.

R. Nunc audiendi tempus. En supplex tuis

3075 Accedo genibus.

H. Dura te necessitas,

3039 faciles] tandem $K C T \mathbf{3 0 4 7}$ post si] sanus forem $K C T \mathbf{3 0 4 8}$ Si falsa nollem dicta pro ueris sequi KCT $\mathbf{3 0 5 1}$ Aulam patere penitus incauti damus KCT $\mathbf{3 0 5 2}$ errati $K \mathbf{3 0 5 3}$ post Adibo] sanctum carcere KCT $\mathbf{3 0 5 4}$ portas] famuli KCT $\mathbf{3 0 5 5}$ post nemo eras. dicentem audiat / sit testis uolo] dicentem audiat KCT $\mathbf{3 0 5 6}$ post remotis] destino affari arbitris $K C T$ 
com uma guerra temível! Para onde me arrastam?

Deuses benévolos, dai-me uma saída; sede-me propícios.

3040

Estamos cercados por terrível inimigo. Nenhum auxílio

nos vem de fora, depois de afugentado o faraó.

Os nossos efectivos não se comparam aos do inimigo.

Para onde te viras, minha alma? A que profeta pedes conselho?

Só Jeremias me disse sempre a verdade.

3045

Com este profeta poderia eu ter evitado

o perigoso contratempo da guerra se, atendo-me à verdade,

tivesse preferido o que estava certo ao que estava errado.

Tenho noção do que é o poder real.

Cercam-nos perniciosos embustes. Frequentemente,

3050

mal avisados, damos livre entrada à mentira no palácio.

Mas seja permitido, a quem sempre errou, ser sensato uma vez.

Irei como suplicante. Pedirei conselho ao ancião prisioneiro.

Abri as portas; fazei sair o profeta;

afastai-vos. Não quero a presença de testemunhas.

3055

Quero falar com o profeta após todos se terem afastado.

JEREMIAS - Ó meu soberano, esta imundície regala teus olhos?

Será que nestas condições me dás por devidamente castigado?

Ou arrastas-me acorrentado para suplícios maiores?

REI - Custa-me realmente olhar-te e impressiona bastante

3060

meus olhos a imundície de teu corpo.

JEREMIAS - Se te causo pena, manda que me retirem estas duras algemas.

REI - Fá-lo-ei. Escuta serenamente minhas palavras.

Os arraiais inimigos cercam nossa pátria.

Se Deus se mostra adverso à nossa causa

3065

e, sem abrandar sua cólera, não atende a um rei que lhe suplica

nem a um povo oprimido por tantas desgraças, resta-me morrer.

JEREMIAS - É a mim que narras tuas desgraças, com voz dorida?

REI - Sim, a ti. Quem mais, a não ser tu, me apoiará? Quem mais

poderá acalmar o Tonante, fremente de indignação?

3070

JEREMIAS - Os que há pouco proclamavam com altivez oráculos falsos

perante um rei crédulo que, insensível aos meus pedidos,

nunca os quis escutar serenamente.

REI - É agora a altura de te escutar. Eis-me feito um suplicante, agarrado a teus joelhos.

JEREMIAS - Uma situação crítica,

« 3057 pascat KCT 3065 Aduersa KCT 3067 Populumque uictum] Plebemque uictam KCT $\mathbf{3 0 6 9}$ fauerit] aderit $K C T$ / aut quis feruidum (feruidam C) KCT $\mathbf{3 0 7 0}$ Tonantis animum flectere iratum (-ti $T$ ) potest $K C T \mathbf{3 0 7 2}$ durus] surdus $K C T \quad \mathbf{3 0 7 4}$ audienti $E$ 
Coacta uirtus esse compellit pium.

Vtinam fuisses integrae quando tuae

Res esse poterant; nunc Deo bellum graue

Gerente, facilem precibus haud pandet uiam.

3080 R. Te deprecantem patrius auertet Deus?

H. Non me, sed urbis respuet causam tuae.

R. Per illa templi sacra, per auiti Dei

Monumenta terris pressa Solymorum, rogo:

Miserere, nobis quaere quid paret Deus.

3085 H. Nota est uoluntas Arbitri aeterni mihi.

R. Effare quaeso. Si Deus miseros iuuat, Habeo salutem; si manum fesso negat, Leuabit animum sola desperatio.

H. Haec ergo missa oracula e caelo cape.

3090 Detestata Deo geris arma et bella uetantem

Composito numquam uoluisti admittere corde?

Quaesita accipies damnati praemia belli.

Vrbe per Assyrios capta nigraeque fauillae

In cinerem uersa, fugiens capieris ab hoste.

3095 R. O dura fata! sorte tam saeua ruet

Huiusce regni gloria?

H. A uobis fluit

Exorta clades. Auctor est mortis suae.

Quicumque sese credere recusat Deo.

R. Cur non furorem cordis emollit sui?

3100 H. Est iustus ultor. Scelera plectit impia,

Ne facinorosus iactet aliquando : "Scelus

Impune feci; me uidet nullus Deus

Nullusque cernit quae patrantur crimina.

Humana nescit acta, sed geminos poli

3105 Conuoluit axes inque stellarum aurea

Sponda recumbens, dat homines fato trahi".

Sed innocentem carcere inclusum uide,

Vinclis onustum, paene consumptum fame.

Meum quod animum Regis offendit scelus?

3110 Quae culpa Proceres fecit inimicos mihi?

3079 facilis $K C T$ / pandet] patet $K C T \mathbf{3 0 8 0}$ deprecantem] supplicantem $K C T$ / patrius] magnus $K C T$ forsan $E \mathbf{3 0 8 1}$ tuae] impiae KCT $\mathbf{3 0 8 2}$ PVER pers. $L \mathbf{3 0 8 4}$ nobis] uates $K C T$ 3085 uoluptas $K \mathbf{3 0 8 8}$ Erit leuamen ipsa desperatio $K C T \mathbf{3 0 8 9}$ Haec ergo monita missa de caelo accipe $K C T \mathbf{3 0 9 0}$ Detestanda $K \mathbf{3 0 9 1}$ uoluisti admittere] potuisti aduertere $K C T$ 
uma virtude forçada, levam-te a ser piedoso.

Tivesse-lo sido quando teus negócios

podiam correr-te bem; agora, quando Deus te move

guerra funesta, Ele não atenderá sem mais tuas preces.

REI - O Deus de nossos pais virará costas às tuas súplicas?

3080

JEREMIAS - Não é a mim que virará costas, mas à causa da tua cidade.

REI - Pelos sagrados rituais do templo, pelos monumentos levantados

ao Deus de nossos pais que se erguem em terras de Jerusalém,

tem piedade, peço-te; procura saber o que Deus nos prepara.

JEREMIAS - Eu conheço a vontade do Juiz Eterno.

3085

REI - Fala, por favor. Se Deus ajuda os desgraçados,

eu tenho salvação; se nega socorro a quem está cansado,

só o desespero me aliviará o espírito.

JEREMIAS - Escuta então estes oráculos enviados do céu.

Empreendes uma guerra detestada por Deus, e nunca te dispuseste 3090

a escutar com serenidade quem a ela se opõe?

Terás os procurados troféus duma guerra condenável:

após a conquista da cidade pelos Assírios e a sua redução a cinzas

de negras faúlhas, serás capturado pelo inimigo ao tentares fugir.

REI - Ó negros Fados! Apagar-se-á com sorte tão cruel

3095

o esplendor deste reino?

JEREMIAS - A desgraça avança,

provocada por vós. É culpado da própria morte

todo o que se recusa a acreditar em Deus.

REI - Porque não abranda Ele o furor de seu coração?

Jeremias - Ele é um justo vingador; castiga os crimes dos ímpios, 3100

não vá o criminoso vangloriar-se de quando em quando:

"pratiquei o crime impunemente; nenhum deus me vê

e ninguém descobre os crimes que se perpetram.

Ele ignora os actos dos homens, mas faz girar o mundo

em torno dos pólos e, recostado em seu leito dourado de estrelas,

3105

deixa os homens andar ao sabor do destino".

Mas repara num inocente encerrado na prisão, ${ }^{109}$

oprimido por algemas, quase a cair de fome.

Que crime cometi que ofendeu o espírito do Rei?

Que mal fiz para que os nobres se tornassem meus inimigos?

« 3094 ante fugiens] Igne coruscanti KCT 3095 ruet] occidet KCT $\mathbf{3 0 9 6}$ Huiusce] Huius $K$ 3097 ante Exorta eras. H. / Exorta] Manatque KCT $\mathbf{3 0 9 8}$ credere] dedere KCT $\mathbf{3 0 9 9}$ emollit] extinguet $K C T \mathbf{3 1 0 0}$ Plectet $K C T \mathbf{3 1 0 1}$ facinoribus $K /$ scelus] nefas $K C T \mathbf{3 1 0 2}$ post feci] crimina haud cernit Deus KCT 3103 om. KCT 3107 Sed] tu add. KCT 
Quod uera fari iubeor imperio Dei?

Vbi illa uatum turba falsorum latet?

Chaldaeus abiit an rediit? Vtri canunt

Age ueriora? Vera si moneo, miser

3115 Cur fio, miserum cur senem fieri iubes?

Leuare uirtus regis insontem boni est,

Premere, tyranni. Flectat hic squalor tuis

Oculis pudendus. Carcere e tetro leua

Nolique Ionathae uincla me scribae pati.

3120 R. Vtinam misericors audiat regem Deus,

Vt aure facilis audio precantem senem.

Carceris in ipso limine solutus mane.

Hic rebus ora perditis ueniam, precor.

H. O Rex benignae sponte naturae, hoc gemo.

3125 Cur pertinaci fraude prauorum peris?

Eheu malorum scelera consiliis facit,

Quae non patrasset, si bonos circa latus

Proceres haberet. Regiae est qualis domus

Familia, tales effici reges solent.

3130 Ita nulla testa citius humorem bibit,

Quam Rex, eorum qui placent, mores olet.

\section{Saphatias. Godolias. Phassvrvs. Hieremias}

SAPH. Ergo solutum carcere uidebo senem,

Quem fata seruant gloriae ut nostrae obstrepat?

GOD. O astra, pontus, terra! Periere omnia.

3135 Ab hoste premimur. Iste capiendam senex

Diuinat urbem. Nulla spes restat. Manus

Et corda frangit bellicoso militi.

Nisi perit, alto Solyma e loco ruit.

Adeste, causam mortis optatae seram.

3140 Funesta dic, heus, fata nos belli manent

An ab hoste laetis patria auspiciis cito

Est liberanda? Quid refers uates Dei?

H. Me flere proprias potius aerumnas decet,

3110 inimicos] inuisos KCT / Cum plebe tota? Poscor ad mortem innocens / Et causa tanti indigna supplicii est, mihi add. KCT [trad. : "...e todo o povo? Reclamam a minha morte quando estou inocente e é indigno de mim o motivo apontado para tal castigo. "] $\mathbf{3 1 1 1}$ iubear KCT 3116 Leuare miseros regis est uirtus boni KCT $\mathbf{3 1 1 7}$ tuos KCT $\mathbf{3 1 1 8}$ ante carcere] Parumper oculos KCT/ e tetro] ex imo KCT $\mathbf{3 1 2 0}$ Regem] uocem $K C \mathbf{3 1 2 1}$ Vt ipse facilis 
Será por dizer a verdade, a mando de Deus?

Onde se esconde a chusma dos falsos profetas?

O Caldeu foi-se embora ou regressou? Vá, de nós ambos

quem falou mais verdade? Se chamo a atenção para a verdade

porque me fazem infeliz? Porque obrigas um velho a ser infeliz?

A virtude de um rei justo está em confortar o inocente;

a de um tirano em oprimi-lo. Que impressione teus olhos

esta vergonhosa imundície. Tira-me desta negra prisão

e não consintas que eu suporte a prisão do escriba Jónatas.

REI - Quem dera Deus ouvisse misericordiosamente o rei

3120

Tal como eu oiço atentamente as preces deste ancião.

Fica à entrada da prisão, livre de algemas.

Ergue aqui tuas preces por esta situação desesperada, peço-te.

Jeremias - Ó rei, benevolente por natureza, uma coisa eu lamento:

Porque te perdes com as contínuas fraudes dos corruptos.

Oh! Os crimes a que o levaram os conselhos dos ímpios

não os teria cometido se estivesse rodeado

de bons conselheiros. A qualidade das pessoas que habitam

a casa real costuma ditar a qualidade dos reis.

Eis como nenhuma lâmpada é tão rápida a consumir o azeite ${ }^{110}$

3130

como o rei a adoptar o comportamento dos que lhe agradam.

\section{CENA XIV: SAFATIAS, Godolias, FASSuro, Jeremias 111}

SAFATIAS - Hei-de então ver livre da prisão o velho,

a quem os destinos protegem, para ofuscar a nossa glória?

Godolias - Ó astros, ó mar, ó terra, tudo está perdido.

Estamos cercados pelo inimigo. Esse velho profetiza

que a cidade vai ser tomada. Nenhuma esperança resta.

Ele quebra a força e a coragem bélica dos nossos soldados.

Se ele não morrer, Jerusalém sofrerá a derrocada.

Aproximai-vos. Eu forjarei a causa da desejada morte.

Diz-nos: está-nos reservada uma guerra funesta,

ou dentro em breve a pátria deverá libertar-se do inimigo, sob melhores auspícios? Que nos dizes, ó profeta de Deus?

JEREMias - Convém-me mais chorar as próprias desventuras

« supplicem admitto senem KCT $\mathbf{3 1 2 4}$ hoc gemol optimae KCT $\mathbf{3 1 2 5 - 3 1 2 7}$ om. $K$ 3128 Proceres] Homines KCT 3131 post rex] suorum moribus uitam imbuit KCT 3135 senex] fore KCT 3136 Diuinat] Conclamat KCT 3138 de loco ruet KCT 3139 seram ] feram KCT $\mathbf{3 1 4 0}$ dic heus] tanti $K C T \mathbf{3 1 4 1}$ patriae $K \mathbf{3 1 4 3}$ Me] Mihi $K C T$ / decet] licet $C T \mathbf{3 1 4 4}$ Euenta sortis dira quam uestrae eloqui $K C T$ 
Euenta miserae dura quam Solymae queri.

3145 GOD. Effare quando nemini uocem negas.

H. Orate Regem precibus offensum nimis;

An forsan aequus Numen aduertat suum.

SAPH. Ambage cur nos tectus obscura tenes?

PH. Abdita precamur corde fatidico explica.

3150 H. Errare cupientibus, aperta ueritas

Immane monstrum, scilicet odium parit.

PH. Responsa quondam multa non iussus dabas;

Dicere rogatus aliquid his Ducibus fugis?

H. Testentur ista uincula, et squalor meus.

3155 Cur tot labores perfero? Quod libera

Oracla uobis ore constanti dedi.

Pater o amore decoris accensus tui,

His non beneuolis Ducibus oraclum dabo.

Quicumque armatus miserae pro moenibus urbis

3160 Stare audet uetitaque fide defendere muros,

Ferro, peste, fame moriens extrema uidebit.

Cautus ad Assyrium si quis defecerit hostem,

Sospes erit patriaeque dolendo in funere uiuet.

Haec equidem statuit Deus, haec oracula pandit.

3165 Maxima Chaldaeis surgent incendia flammis,

Quae Solymam incensam prolapsa et tecta relinquent.

PH. O terra patiens sceleris infandi taces,

Et non dehiscis? Non repentino sinus

Aperis tumultu perque patefactum specum

3170 Talia loquentem, talia audentem uoras?

Violare patriae debitam carae fidem

Cuinam deorum placuit? Et auitum Deum

Credemus ore barbari istius loqui?

Deficere ad hostem et perfugas fieri iubes?

3175 Fauete, demus Tartaro inuisum caput.

SAPH. Rex prodit. Ipse crimen obiciam reo.

\section{REX ET CETERI CVM HIEREMIA}

SAPH. Quis bella pro te dura seruando gerat?

3146 post precibus] aethereae plagae $K C T \mathbf{3 1 4 7}$ An] Et $C$ Si $K T \mathbf{3 1 4 9}$ explica] excute KCT 3150 capientibus T corr. s.u. ex cap- C 3151 Immane] Crudele KCT 3153 ante Ducibus] nulla tot KCT $\mathbf{3 1 5 4}$ Testantur $L \mathbf{3 1 5 5}$ perfero] pertuli KCT/Quod] Quia KCT 3156 Oracla] Responsa $K C T 3161$ extrema] sua fata $K C T \mathbf{3 1 6 3}$ Hospes $K \mathbf{3 1 6 4}$ equidem] etenim $K C T \longrightarrow$ 
do que queixar-me das desgraças que abalam a mísera Jerusalém.

Godolias - Fala, já que a ninguém negas a palavra.

JEREMIAS - Pedi ao Rei, demasiado importunado com pedidos.

Talvez ele se disponha a alterar favoravelmente a sua vontade.

SAFATIAS - Porque nos ocultas a verdade, refugiando-te em ambiguidades?

FAssuro - Revela-nos o que está oculto, tu que conheces o futuro.

JEREMIAS - Para quem deseja permanecer no erro, conhecer a verdade

faz nascer um monstro horrível, a saber, o ódio.

FAssuro - Em tempos, davas muitas respostas sem seres obrigado;

agora, que te pedem, recusas-te a falar a estes generais?

JEREMias - Falem por si estas algemas e o meu estado imundo.

Porque suporto tantos sofrimentos? Por vos ter anunciado,

3155

sem desanimar, oráculos isentos?

Levado pelo amor da tua glória, ó Senhor,

eu proclamarei um oráculo a estes generais pouco benévolos.

"Quem ousar permanecer armado diante das muralhas da infeliz cidade e defender suas muralhas com lealdade interdita verá o fim dos seus dias morrendo pela espada, pela peste ou pela fome.

Se alguém, prudentemente, se passar para o lado do inimigo assírio, será poupado e viverá lamentando a sorte funesta de sua pátria.

Eis os decretos de Deus; eis os oráculos que Ele me revelou.

Ateados pelos Caldeus, deflagrarão pavorosos incêndios

que deixarão Jerusalém abrasada e suas casas em ruínas". ${ }^{112}$

FAssuro - Ó terra, suportas em silêncio tão nefando crime

e não te entreabres? Não escancaras tuas entranhas,

estremecendo num repente, e não devoras nos abismos

quem ousa proferir tais palavras?

3170

Violar a fidelidade devida à pátria amada,

a que deus agradaria isso? E haveremos de acreditar

que o Deus de nossos pais fala pela boca deste bárbaro?

Ordenas que passemos para o inimigo e nos tornemos desertores?

Dai-me o vosso apoio. Mandemos para o Tártaro esta vida odiosa.

SAFATIAS - O rei aproxima-se. Eu próprio apresentarei queixa contra o réu.

\section{CENA XV: O Rei e os mesmos, com JeREMIAS 113}

SAFATIAS - Quem sustentará uma guerra difícil para te proteger?

— 3165 Turbida uictores chaldaei incendia tollent KCT 3166 eras. In ante Quae / Et Solymae iniectis incendent pergama taedis KCT 3169 patefactam KCT $\mathbf{3 1 7 1}$ carae] ac sacram KCT 3174 eras. Diffi ante Deficere / post hostem] pessime Assyrium mones KCT 3176 SAPH. pers. om. $L$ / ipse] ergo $C$ ego $K$ 
Quis nocte summis excubet muris uigil

Si uiuere hominem peste peiorem sinis?

3180 R. Aliquidne uates sceleris admisit noui?

PH. Antiqua scelera scelere cumulauit nouo.

R. Age, cur salutis uiuis oblitus tuae?

Non te coercent compedes, carcer, fames?

Aperite quod est crimen admissum modo?

3185 GOD. Penitus maleficis turbat hoc regnum artibus.

Euersionem patriae horribilem canit.

Transfugia suadet. Quis manu forti lares

Defendet urbis? Quis tuam bello teget

In hoc salutem? Furia si talis suae

3190 Linguae ueneno militem eneruat tuum?

R. Transfugia suades?

PH. Garrula senectus tacet.

H. Quaecumque iussit ille regnator poli, Ea sum locutus et loquar, quamquam ferox Rabies tyrannos armet in caput meum.

3195 PH. Quas quaerit artes, quem locum quaerit fugae.

Abominandum dede portentum neci.

Nos, regna, patriam libera tanto metu.

H. Cognosce causam et iudica. Vitae ac necis

Aequus inimicos arbitros nemo creat.

3200 R. Parere ducibus cogor. In uestra manu

Vitam relinquo perfugae inuisam senis.

Ducibus negare nil uolo aut possum meis.

H. Istisne uatem dedis? Extingui iubes?

PH. Praedam tenete. Iam semel uere occidat.

3205 Obnubite caput, dira mactetur fera.

SAPH. Barathri uorago uasta caenosi auferat.

H. Vbinam locorum uersor? An me barbarae

Gentes trucidant? An necant ciues mei?

PH. Diuinus olim morte uicina incipis

3210 Titubare? Caedem quo loco danda est, uide.

H. Video et uidebit Ille qui semper manum

Facilem tetendit rebus in duris pio.

GOD. Aperite barathri lubricum uasti lacum.

$\mathbf{3 1 7 8}$ eras. tota s. $u$. summis / post summis] muris excubet summis KCT $\mathbf{3 1 7 9}$ hominem peste] senem hunc morte $K C T$ / peiorem] priorem $K \mathbf{3 1 8 0}$ Aliquodne demens crimen admisit nouum? KCT $\mathbf{3 1 8 1}$ cumulauit] renouauit KCT comulauit $L \mathbf{3 1 8 3}$ Non sat luisti carcere, fame, uinculis KCT $\mathbf{3 1 8 4}$ post crimen] infausti senis $K C T \mathbf{3 1 8 5}$ hoc regnum] hanc urbem $K C$ 3186 horribilem] horrendam KCT 3177 Didasc. Om. KCT 3188 Defendat KCT 3192 ille] 
Quem passará a noite vigiando no cimo das muralhas, se tu deixas viver um homem pior do que a peste?

REI - Porventura cometeu o profeta novo crime? 3180

FAssuro - Acrescentou mais um aos seus velhos crimes.

REI - Vá, porque vives esquecido do teu bem-estar?

As algemas, a prisão e a fome não te corrigem?

Que crime acabou ele de cometer, dizei-me.

GoDOLIAs - Ele perturba profundamente o reino com suas artes maléficas.

3185

Anuncia uma catástrofe terrível para a pátria, apela à deserção. Quem defenderá energicamente

os lares da nossa cidade? Quem garantirá a tua segurança

nesta guerra se uma Fúria como esta, com o veneno de sua língua, enfraquece o ânimo dos teus soldados?

REI - Tu apelas à deserção?

FASSURO - A velhice palradora cala-se.

Jeremias - Tudo quanto o Soberano celeste me ordenou,

tudo isso eu anunciei e anunciarei, ainda que uma raiva feroz

leve os tiranos a atentarem contra a minha vida.

FASSURO - Ele procura estes artifícios; busca uma ocasião para fugir.

Entrega à morte este abominável flagelo

e liberta-nos a nós, ao reino e à pátria de tamanho terror.

JEREMIAS - Conhece a causa e julga. Ninguém que seja imparcial

nomeia inimigos como juízes da vida e da morte.

REI - Vejo-me forçado a dar razão aos generais. Entrego

3200

em vossas mãos a vida odiosa deste velho desertor.

Nada quero, nem posso, negar aos meus generais. ${ }^{114}$

JEREMIAS - Entregas um profeta a gente desta? Ordenas que me matem?

FASSURo - Segurai a presa. Que ele morra de uma vez por todas.

Vendai-lhe o rosto. Entreguem à morte a terrível fera.

SAFATIAS - Que o receba a profunda voragem do báratro lamacento. ${ }^{115}$

JEREMIAS - Para onde me arrastam? É gente bárbara

que me assassina ou são concidadãos meus que me matam?

FAssuro - Tu, em tempos um adivinho, começas a titubear

face à iminência da morte? Vê onde te deverão entregar à morte.

JEREMIAS - Eu vejo, e vê-lo-á quem sempre estendeu ao justo

uma mão amiga em momentos difíceis.

Godolias - Abri a viscosa cisterna que conduz ao báratro.

$\longleftarrow$ monita KCT 3193 Loqui, haec loquemur inuidia quamquam infera KCT $\mathbf{3 1 9 4}$ rabies] Saeuos KCT 3196 dede portentum] deuoue monstrum KCT 3198 post causam] testor aeternum Deum KCT 3199 om. KCT 3201 perfugae] perditi KCT $\mathbf{3 2 0 3}$ Vatemne dedis? Siccine extingui iubes KCT 3205 Obnuite $K \mathbf{3 2 0 6}$ ante uorago] hunc KCT $\mathbf{3 2 1 0}$ danda est] excipias KCT 3211 Videt $K$ 
Date, date funes. Eia. Circumcingite.

3215 H. Vitae auferendae parua dum restat mora, Liceat precari numen aeternum Dei.

PH. Precare uanae tempus usurae damus.

H. Te Pater omnipotens uicina accersere morte

Cogor, et auxilium moriendi animumque precari.

3220 Nam uitae iam finis adest utinamque fuisset

Ante datum tumulo fessam posuisse senectam

Secretosque pios tacitas adiisse per umbras.

Candida cygneis albent mihi tempora plumis

Inque malis aetas senuit transacta ferendis.

3225 Et nunc mole ruo pessundatus aerumnarum.

Te propter Solymae gentes aulaeque tyranni

Oderunt. Rex ipse suis conuiuet et ipsi

Praecipitem barathri stagnante uoragine mergunt.

SAPH. Abripite.

GOD. Detrudite.

PH. Satisfactum tibi est.

3230 Accede in imum lapsus orabis lacum.

H. Aeterne princeps una spes semper meae

Vitae fuisti, famulus extremum precor:

Tua uita, tua mors est; cadam ut uixi tuus.

\section{CHORVS QVARTVS}

Regni si quis amat sceptra Dauidici,

3235 Humectet lacrimis ora rigantibus.

Virtus ima tenet carceris, incolunt

Impunita domos crimina regias.

Haec est nobilium nempe licentia.

Non diuina timent iura refigere.

3240 Aequas praetereunt, exitiabiles

Leges constituunt. Pauperis aequior

Succumbit tumidae causa potentiae.

Haec partu generat monstra nefario

Nullo nobilitas iure coercita.

3245 Coniuentis alit gratia Principis.

Qui reges adhibent frena minoribus,

Dynastis adimunt nulla uolentibus,

3216 numen] breuiter $K C T$ / Dei] Deum KCT 3217 uanae] uiuae $K$ / damus] datur $C T$ 3223 albent] canent $K C T \mathbf{3 2 2 4}$ aetas $m g$. C $\mathbf{3 2 2 7}$ eras. ...........post ipse / post ipse] necem decreuit et imi KCT 3228 mergunt] condunt KCT 3229 GOD. pers. om. KC / PH. pers. 
Trazei cordas. Vamos, amarrem-no.

JEREMias - Enquanto me restam ainda breves momentos de vida, permitam-me que eleve preces ao poder eterno de Deus.

FASSURO - Ergue tuas preces. Condescendemos com usos inúteis do tempo.

JEREMIAs - Pai Omnipotente, vejo-me forçado, às portas da morte,

a virar-me para Ti e a pedir-Te ajuda e coragem para morrer.

O fim de minha vida já está próximo. Oxalá me tivessem concedido,

há mais tempo, entregar à sepultura esta velhice cansada e,

através das silenciosas sombras, ter-me dirigido à morada dos justos.

Minhas têmporas alvejam com uma penugem de cisne

e minha vida passada consumiu-se suportando desgraças.

E agora acabo submergido por vaga enorme de tribulações.

Por tua causa, sou odiado pelos habitantes de Jerusalém

e pelos tiranos da casa real. O próprio rei é conivente com os seus, e são estes que me precipitam na voragem lamacenta do báratro.

SAFATIAS - Agarrem-no.

GODOLIAS - Atirem-no.

FAssuro - Foi-te feita justiça.

Vem cá. Rezarás depois de teres escorregado para o fundo do lago.

JEREMIAS - Ó Príncipe Eterno, tu foste sempre a principal e única esperança de minha vida. Este teu servo faz-te um último pedido: pertencem-te a vida e a morte; tal como vivi, que eu morra, sendo teu.

\section{CORO IV 116}

Se alguém ama os ceptros do reino de David deixe correr o pranto e o rosto banhar-se em lágrimas.

A virtude está encerrada no fundo do cárcere e no palácio real habita impunemente o crime. É esta, não há dúvida, a liberdade dos nobres. Eles não receiam anular leis divinas.

As justas, põem-nas de lado e substituem-nas por leis funestas. A causa mais justa do pobre sucumbe perante a arrogância do poder.

Estes monstros, gera-os a nobreza de forma abominável sem que a constranjam quaisquer regras de direito.

Encoraja-a a complacência conivente dos príncipes.

Os reis, que aos humildes impõem freios

e em nada contrariam os desejos dos poderosos,

« om. KC / tibi] sat KCT $\mathbf{3 2 3 0}$ eras. labere ante lapsus / lapsus orabis] labere ut debes $K C T \mathbf{3 2 3 1}$ Aeternae $L \mathbf{3 2 3 2}$ extremus $K \mathbf{3 2 3 4}$ amat $m g . K \mathbf{3 2 3 8}$ nempe] tuta $M K C T$ 3241 constituunt] instituunt $M K C$ 
Fundamenta locant prima tyrannidi.

Totis aedificant cetera uiribus,

3250 Allecti Proceres igne cupidinis.

His ne posteritas digna laboribus

Ornamenta memor forte requireret,

Conflauere metum signa ferentia,

Quae spectanda suis molibus erigunt.

3255 In primis foribus lugubre crinibus

Passis alma Fides dum canit, exulat,

Expulsaeque locum ritibus occupant

Detestata nouis Numina Gentium.

Tum portenta manus, quae scelus exprimit,

3260 Ad uiuum propriis tincta coloribus,

Vinclis conubium triste iugalibus

Ruptum maeret. Habet risus adulteros

Rex, probrum thalami nulla quod expiet.

Ipsi dissimulant omnia coniuges,

3265 Auctorum metuant quod uiolentiam.

Amens alter abit frater in alterum,

Certi uulneribus funera mutuis

Intentare sibi, uel dare toxicum

Vt letale bibens uadat in inferos.

3270 Has inter scelerum luget imagines

Pulsatus genitor quem sua uerberat

Indignis soboles impia fustibus.

Innectunt alii iura clientibus,

Causas non dubias litibus implicant.

3275 Nidis ut uolucres oua tepentibus

Excludenda fouent, plurimus incubat

Sic grex diuitiis, unde salutifer

Partus non sequitur, praua sed omnium

Detestata nimis uoce tenacitas.

3280 His monstris sociant arma, minacibus

Monstrat prodigiis quae Deus impia.

Et nolente canit Numine classicum

Rex cum Principibus. Qui manet exitus

Hanc rerum faciem? Bellica seruitus

3285 Adductura uagae frena licentiae. 
lançam os primeiros alicerces da tirania.

O resto fazem-no, com todo o empenho, os nobres, seduzidos pelo fogo da cobiça.

Para que a posteridade ao recordar-se não viesse, porventura, a exigir ornamentos dignos destes trabalhos, eles fabricaram brasões que inspiram medo e que dão a contemplar nas fachadas de seus palácios.

À porta de casa, com os cabelos em desalinho, 3255 Alma Fides ${ }^{117}$ vive exilada cantando em modos doridos, e o lugar da que foi expulsa, ocupam-no, com novos ritos, as detestáveis divindades dos gentios. Depois, sua mão estendida, em denúncia do crime, tingida ao vivo com cores próprias, 3260 deplora, com pesar, o casamento desfeito de seus laços conjugais. Tem o riso adulterado o rei, pois nada reparará um tálamo desonrado. Os próprios cônjuges tudo dissimulam, por recearem a violência das autoridades.

O irmão volta-se desvairado contra o irmão, ambos decididos a golpearem-se até à morte, ou a envenenarem-se mutuamente, para que um vá parar ao Inferno com a poção fatal. Entre tais cenas de crimes, lastima-se o pai, maltratado, barbaramente fustigado a chicote pelos filhos, ímpia descendência.

Outros ligam-se por juramento a seus protegidos e entravam com demandas causas inequívocas. Tal como as aves que em tépidos ninhos ${ }^{118}$ 3275 chocam ovos impróprios, assim muitas pessoas deitam-se sobre riquezas que nada de bom produzem, mas uma insensata avareza por todos fortemente detestada. A estes monstros medonhos associam eles a guerra 3280 que Deus, com prodígios, denuncia como ímpia. $\mathrm{E}$, contra a vontade de Deus, o rei e os generais fazem soar a trombeta. Que fim está reservado a este estado de coisas? A servidão militar que porá freio à liberdade desregrada. 


\section{ACTVS QVINTVS}

\section{Pver Hieremiae. Hieremias, ex lacu}

P. Aetate iuueni proprior, aut adhuc puer,

Tutore sub quo solus inuento feram

Hanc orbitatem lugubrem? Credam alteri

Cui me magistro? Periit, et periit mihi

3290 Auriga Solymae, qui mea uitae dabat

Praecepta, qui me moribus alebat suis.

Oculi quid agitis ? Flumine undantes genae

[p.114]

Manate largo. Plange, suspira, eiula

Miselle, lacrimis exibe inferias patri.

3295 H. Aliquisne loquitur pectore in miseros pio,

Qui de silenti me leuet tractum lacu?

P. Horrore quatior. Sub solo quisnam gemit?

H. Humanus homini quis dabit amicam manum?

P. Rursus ad aures peruenit tristis sonus.

3300 H. Miserere quisquis supera telluris tenes.

Caliginoso gurgite immersum eripe.

P. Vox prodit imo maesta de barathro. Meus

Si uiuit ille genitor, o Superi! Pater?

H. O nate, crede ne parentem mortuum,

3305 Sed uiuit instar mortui. Vitae mora

Tantilla superest. Quaere quo uiuum modo

Tenebricoso de lacu uatem eruas.

P. Saltu sub imum uado praecipiti lacum.

Amor fidelis patitur haud istas moras.

3310 H. Meliora cupio; sospes et saluus mane.

Tenebrescit atris ima gurgitibus palus.

Contaminatus squaleo, caeno grauor

Vliginoso, quod per occultas aquae

3286 iuueni] puero KCT 3289 et] at KCT 3292 undantes] rubentes KCT 3297 quisnam gemit] uocem audio KCT 3299 tristis] nostras KCT 3301 P. pers. L / immersum eripe] infixum erue KCT Vox tristis imo prodit e Barathro, meus KCT 3304 crede ne] nate mi KCT $3305 \mathrm{Si}$ 


\section{ACTO V}

\section{CENA I: Moço e Jeremias, este dentro do lago}

Moço - Quase um jovem em idade ou ainda uma criança, sob que tutor hei-de suportar sozinho minha triste orfandade? A que outro mestre me vou confiar? Ele morreu e morreu para mim o guia de Jerusalém, o conselheiro de minha vida, aquele que me dava alento com seu modo de ser. Que se passa convosco, meus olhos? Faces molhadas, deixai correr meu pranto em abundância: chora, suspira, lamenta-te, miserável. Oferece a teu pai um sacrifício de lágrimas.

Jeremias - Quem fala é alguém que se compadeça dos miseráveis, 3295 e que me possa valer arrancando-me deste lago de silêncio? Moço - Tremo de horror. Quem solta gemidos debaixo da terra? JEREMIAS - Haverá um ser humano que estenda a outro sua mão amiga? Moço - Chega-me de novo aos ouvidos uma voz aflita.

JEREMIAS - Tem piedade! Sejas quem fores tu que pisas terra firme, 3300 arranca do escuro abismo quem lá se encontra mergulhado.

Moço - A voz apresenta-se-me chorosa, vinda do fundo do báratro. Será que meu pai está vivo? Deuses do alto! Pai? Jeremias - Ó meu querido filho, acredita. Teu pai não está morto, mas vive como um morto. Muito pouco tempo de vida me resta. Descobre forma de me retirares ainda vivo deste tenebroso lago.

Moço - Vou saltar para o fundo desse lago.

Um amor extremo não suporta demoras destas.

JEREMIAS - Quero melhor; mantém-te aí são e salvo.

$\mathrm{O}$ interior deste lago escurece por entre gargantas medonhas.

Estou coberto de imundície. Incomoda-me lama viscosa deixada por águas filtradas

« credis esse uiuit, at uitae mora KCT 3310 post cupio] quo loco sistis mane KCT 3312 grauor] grauis KCT 3313 Vliginoso] Caliginoso $K$ 
Latebras liquatae fugerint, stabili pedem

3315 Tellure firmo. Viuo sed turpi gelu

Fameque morior. Affer auxilium, puer.

P. Vitam relinquam, morte si tuam mea

Redimere possum. Subleuat pressos Deus.

Aduentat ille notus insigni Aethiops

3320 Pietate, Regi gratus et in aula frequens.

H. O magne Rector orbis, ut numquam pia

Repellis hominum uota! Cum nullae manent

Spes in periclis, auxilia praebes tuis.

\section{Pver Hieremiae. Abdemelhec. Hieremias}

P. O Abdemelhec fide, generoso in pium

3325 Sanctumque uatem corde, ne spernas meas

Vatisque lacrimas. Conditum taeterrima

Palude, paene mortuum patrem leua.

ABD. Adhucne caelo fruitur aetherio pater?

P. Vix uiuit. Anima pendet extremo halitu.

3330 Succurre, quando te obtulit nobis Deus.

ABD. Dilecte caelo genitor, o uates sacer, Amice, pure sceleris, indigne hoc malo, Respexit alti conditor Olympi tuum Aequus laborem. Vive, quo uiuas diu.

3335 Nondum suprema te uocat leti dies.

H. Atroce quantum mortis in periculo

O uita amaris! Concidit ut amor tui,

Dura moriendi cum fugit necessitas!

Graue sub profundo gurgite putabam mori;

3340 Redire in auras grauius apparet malum.

Quid uiuus opto? Spero quam pacem dari?

ABD. Ascende, caelo digne; te tellus nequit

Attonita ferre; moribus stupet tuis.

Et quo solutis quisque se frenis magis

3345 Contaminandum sordibus scelerum dedit,

Eo fit hostis grauior in caput tuum.

Haec trita longi temporis putri situ

3314 Scatebras KCT 3316 auxilium] o opem KCT 3318 Redimere] Reuocare KCT / Sortem serenus aspicit nostram deus add. KCT [Trad. "Deus vê serenamente a nossa sorte"] 3320 gratus] carus $K C T \mathbf{3 3 2 1}$ magne] summe KCT 3322 Repellis] Destituis KCT 
por secretos esconderijos. Tenho os pés em terra firme.

Estou vivo, mas sinto-me morrer ignobilmente

de frio e fome. Vem em meu socorro, meu filho.

Moço - Renunciarei à vida se, com minha morte,

puder salvar tua vida. Deus socorre os oprimidos.

Está a chegar o Etíope, conhecido por sua insigne piedade,

estimado pelo rei e frequentador assíduo do palácio real.

3320

JEREMIAS - Ó Soberano excelso do universo, tu nunca rejeitas

os justos pedidos dos homens! Quando, face ao perigo,

não resta qualquer esperança, tu vens em auxílio dos teus.

\section{CENA II: Moço, Abdemelec, Jeremias 119}

Moço - Caro Abdemelec, de coração generoso para com o piedoso e santo profeta, não desprezes minhas lágrimas

e as do profeta. Enterrado neste hediondo charco está meu pai, quase morto. Socorre-o.

AbDemelec - O teu pai ainda não está gozando no Céu supremo? Moço - Quase não vive. Tem a vida suspensa por um fio.

Acode-nos, pois Deus enviou-te ao nosso encontro.

ABDemelec - Ó Pai amado do Céu, ó sagrado profeta, meu amigo, sem mancha de crimes, indigno deste infortúnio, o justo Criador do elevado Olimpo pôs os olhos em teu sofrimento. Vive, para viveres longo tempo. O derradeiro dia da morte ainda te não reclama.

JEREMIAS - Ó vida, face ao atroz perigo da morte como és apreciada! Como desaparece o amor por ti quando se afasta a dura inevitabilidade da morte.

Eu julgava que era penoso morrer no fundo da cisterna; regressar à luz do dia surge-me como desgraça maior.

Que desejo eu em vida? Que paz espero me seja dada?

AbDemelec - Sobe. És digno do céu. A terra, atónita, não pode suportar-te; fica estupefacta com o teu carácter.

E quanto mais cada um, desenfreadamente, se deixa contaminar pela sordidez do crime, mais perigosamente se torna inimigo da tua vida.

Coloca sob os cotovelos estes panos gastos e sujos,

« 3324 impium $L \quad 3326$ Vatisque] Patrisque KCT 3327 patrem] uatem KCT 3337 amaris] amara $K \mathbf{3 3 4 4}$ solutis] soluto $K C T$ / frenis] freno $K C T$ 
Suppone cubitis; sparteos funes liga.

Nos moliemur, dulce retrahentes onus.

3350 H. Qua te Abdimelhec laude cumulabo? Mihi

Dator o salutis unice, o columen meum!

ABD. Tenete comites singuli funes.

H. Age,

Age, colligatum trahite. Securus feror.

ABD. Aequate uires; dispari nemo trahat

3355 Conamine aegrum. Molliter oportet senem

Extrahere fractum tam tenebroso e lacu.

P. Desiderate genitor optato in sinu

Possem beatus emori! hic mortem uolo.

H. Qui regis imperiis elementa, tot astra, tot orbes

3360 Rex superum, quo rursus agor? Feror exul in auras,

E barathro humenti mediaque uoragine ducor,

Vt mea frangatur damnis grauioribus aetas?

Ille lacus nigroque palus taeterrima caeno

Non semel inuisam potuit mihi rumpere uitam.

3365 Sic umeros, sic ora feram? Sic inde redibunt

Caenosa tellure pedes? ita sordidus ibo

Vt luteum uatem Procerum me rideat ordo?

ABD. Meliora, uates, axe de supero dabit

Deus ipse, mundi Rector et rerum Pater.

3370 Quin ipse Rex amicus obscuro e lacu

Mandauit ut te tollerem et haberem tuae

Curam senectae. Debitas grates age.

N. O bella grauia, bella quis demens amat?

Quis arma demens sequitur et pacem fugit?

3375 Cupido ferri dira scelerati eruit

Vrbem, Penates, sacra et Isacidum genus.

Miseri perimus; morimur oppressi fame

[p.117]

Vulgatque morbos lurida attactu lues.

Ab hoste misera Solyma uastatur fero.

3380 ABD. Cur haec dolore uerba tam graui refers?

Effare causam prode. Quid triste accidit?

N. Omnia timentur grauia, funesta, aspera.

Rex sacrosancte te senex uocat; mora

3350 mihi] piae $K C /$ pie $T 3351$ om. o ante salutis $K C T /$ unice om. $K \mathbf{3 3 5 2}$ Tenete funes singuli, numquid bene KCT / HIER. pers. om. E / age] bene E $\mathbf{3 3 5 3}$ Te colligasti? H. Trahite. Securus feror KCTE $\mathbf{3 3 5 4}$ trahat] auferat KCT $\mathbf{3 3 5 6}$ Extrahere] Reuocare KCT / a tam tenebroso lacu KCT $\mathbf{3 3 5 8}$ mori $K \quad \mathbf{3 3 5 9}$ orbes] urbes $L \quad \mathbf{3 3 6 0}$ auras] altum $K$ 3361 humenti] infami KCT 3362 grauioribus $m g$. Cx 3365 umeros] corpus KCT 3366 post 
há muito sem uso; amarra-lhes cordas de esparto.

Nós puxaremos, para retirar suavemente o peso de teu corpo.

Jeremias - Com que elogios te cumularei, Abdemelhec?

Ó meu único salvador, sustentáculo da minha vida!

AbDemelec - Segure cada um suas cordas, companheiros.

JEREMIAS - Vá,

puxai-me; já estou ligado; podem puxar-me sem riscos.

AbDemelec - Conjugai as forças, que ninguém puxe um doente

desencontradamente. Convém que o debilitado ancião

seja retirado suavemente de tão tenebroso lago.

Moço - Ó pai desejado, pudesse eu morrer feliz

em teu querido regaço! Eu quero morrer aqui.

JEREMIAS - Tu que com autoridade reges os elementos, estrelas e planetas,

ó Rei dos deuses, para onde me conduzem de novo? Erguem-me no ar, 3360

fazem-me sair do húmido báratro e do interior do abismo

para que minha vida seja afectada por contratempos piores?

Aquele lago e aquele tétrico pântano, com sua negra imundície, não conseguiu acabar de vez com esta minha odiosa existência.

Apresentarei assim meus ombros e minhas faces? Regressarão assim

meus pés enlameados de terra? Irei assim tão sujo

que a nobreza se rirá de mim, um profeta enlameado?

ABDEmelec - Melhores coisas, profeta, do alto céu te dará

o Deus que governa o mundo e é pai do universo.

Mais: foi o rei quem, amigavelmente, ordenou

3370

que te retirasse do sombrio lago

e cuidasse da tua velhice. Deves agradecer-lhe.

Mensageiro - Ó guerras terríveis, quem é o louco que as ama?

Quem é o louco que vai atrás das armas e foge da paz?

A sinistra paixão pela abominável espada destrói

a cidade, os Penates, o culto e a raça dos filhos de Isaac.

Estamos perdidos de todo; morremos oprimidos pela fome

e uma lívida peste espalha doenças contagiosas.

A infeliz Jerusalém é devastada pelo feroz inimigo.

ABDEMELEC - Porque proferes tais palavras com dor tão profunda?

Fala! Diz-nos o motivo? Que aconteceu de lamentável?

Mensageiro - Receamos tudo o que há de penoso, funesto, desagradável.

O rei chama-te, venerável ancião; demores o que demorares,

« pedes] maculataque terga KCT 3367 Vt proceres in me totiens sua uerbera nudent? KCT 3369 ipse] ille KCT $\mathbf{3 3 7 0}$ ut opaco eras. obscuro s. u. / Quin rex amicus iussit, ut opaco e lacu KCT $\mathbf{3 3 7 1}$ te sancte uates tollerem, et haberem tuae KCT $\mathbf{3 3 7 3}$ Nuntius pers. mg. 3375 eruet $K \quad 3376$ Isacidum] hebraeum $K C T \quad 3378$ lurido $C T$ liuido $K \quad 3379$ Ab] Et ab KCT 3381 prode] prome $K C T$ 
Quacumque facta, serus ad Regem uenis.

3385 H. Alio uolebam pergere. O casum grauem!

O patria Solyma! Numinis magni o domus!

In te supremae cladis incumbit dies.

Iam flamma taedis atra succensis micat.

Audio fragorem. Resonat armorum sonus.

3390 Abd. Abeamus istinc, hostium clamor uocat.

\section{NABVZARDANVS aggreditur urbem}

NABVZ. Custode nostri bellico portae carent

Commilitones; nuda praesidiis patent

Moenia relictis. Eruite ferro et face.

Det uicta poenas Solyma perfidiae suae.

3395 Quicquid cruentus uictor in uictos potest

Audete. Iubeo. Vester Assyriae prior

Iubet Imperator. Eia clamorem date,

Corripite subito dum licet cursu fores.

\section{Chaldaei}

Ostia belligeris aperite securibus, eia

3400 Eia agite, eia patent iam limina, scandite muros.

\section{SOLYMAEI}

Hostis adest, ciues, patefactis moenibus intrant.

Occidimus, fumant muri flammaeque uoraces

Lambunt tecta, sacri gradiuntur ad atria templi.

3405 NABVZ. Eia, occupate limen; incendat domum

Ignis sacratam, iacite flammantem facem.

C1. O pater omnipotens, hostilem auerte furorem.

Sacrilegi in sacris ardent penetralibus ignes.

\section{REX cum liberis aufugit.}

R. O falsa regni gloria! O fallax bonum!

$3386 \mathrm{om}$. KCT 3387 incumbet $L$ / Iam, iam suprema in patriam incumbit (incumbet $K$ ) dies KCT 3389 resonant $C \quad \mathbf{3 3 9 0}$ om. KCT 3391 nostri] uacuae KCT 3392 nuda] nulla K 3393 Moenia] Pergama KCT 3394 perfidae L 3397 eia] ea K/ eras. vers. 3399 post vers. 3397 K 3400 Eia agite, eia patet iam porta, capessite muros KCT $\mathbf{3 4 0 1}$ intrat KCT 
chegarás atrasado à presença do rei.

JEREMIAS - Pretendia encaminhar-me para outro sítio. Que desgraça! 3385 Ó Jerusalém, minha pátria! Ó templo do grande Deus! vai desabar sobre ti o dia da suprema desgraça.

Já crepitam chamas medonhas sobre madeira ateada. Ouço um fragor. É o ressoar das armas.

ABDemelec - Vamo-nos daqui; o clamor do inimigo apela à guerra.

\section{CENA III: NABUZARDANO ataca a cidade ci20 $^{12}$}

NABUZARDANO - As portas encontram-se desprovidas de custódia militar, companheiros de armas; as muralhas estão abandonadas, as guarnições desocupadas. Arrasai-as a ferro e fogo.

Que Jerusalém receba, com a derrota, o castigo da sua perfídia.

Tudo o que um vencedor sanguinário pode ousar contra os vencidos, ousai-o, ordeno-vos. É o vosso imperador, o soberano da Assíria, quem vo-lo ordena. Vamos, irrompei em gritos. Apoderai-vos já das portas da cidade, enquanto podeis.

\section{Caldeus}

Abri as portas com os machados de guerra; eia, vamos! Coragem, as portas já se abrem; subi às muralhas.

\section{CidAdÃos DE JERUSALÉM}

O inimigo aproxima-se, cidadãos; invadem as muralhas escancaradas.

Estamos perdidos. As muralhas deitam fumo e chamas vorazes rodeiam as casas e propagam-se na direcção do templo sagrado. NABUZARDANo - Vamos, ocupai as entradas; deitai fogo ao templo sagrado; arremessem tochas ardentes.

Clamor - Pai omnipotente, afasta de nós a fúria do inimigo; nos santuários sagrados crepitam chamas sacrílegas.

\section{CENA IV: O REI foge com os filhos ${ }^{121}$}

REI - Ó vã glória do poder! Ó bem falaz! ${ }^{122}$

« 3403 Lambunt tecta, hostes nudos (nudo $K$ ) sese ense cruentant (cruentat K) KCT 3404 post limen] hoc templi ardui KCT $\mathbf{3 4 0 5}$ ante iacite] Cur cessat ignis KCT $\mathbf{3 4 0 6}$ Caelicolae o Superi diuino occurrite templo KCT $\mathbf{3 4 0 7}$ Sacrilegae populant adyta et penetralia flammae $K C$ 3409 Hos regna secum clara successus habent? KCT 
Hos ipsa tandem regna successus habent?

3410 Hunc sceptra finem grauia dant regi mihi?

Vbi sum? Quid egi? Quo trahor? Quo me impulit

Fortuna? Cur me sede deceptum aurea

Sedere fecit? Caelites! Vrbem rogis

Ardere cerno. Fumat Isacidum decus

3415 Templum, fauillas adyta glomeratas uomunt.

Et haec ruina praemium est sceleris mei.

Cauere potui, si bono uati fidem

Cautus habuissem. Cur Dei spreui minas?

In uera redeunt supplicia. Miles tenet

3420 Chaldaeus urbem uictor, et capta ferox

In plebe caedem barbara exercet manu.

Interque flammam raptor expugnat domos.

Quid anime pendes? Cernere hanc cladem potes?

Auerte luctum, perge, meruisti, cade.

3425 Patria ruinis me cadens tegat suis.

Sepulta fiat patria sepulcrum mihi.

FIL MA. Per sceptra iam non flagito amissa o parens,

Per te rogabo. Dum licet, mortem fuge.

R. Per me rogas, o nate? Me propter ruit

3430 Incensa Solyma. Testis excisae ferar

Patriae superstes? Absit. Occurram meis

Solymaeque fatis, antequam capiar, libens

Iugulum petenti sponte uictori dabo.

FIL. MI. Quo pergit ire caecus, o parens, furor?

3435 Prolem suo relinquis orbatam patre

An ad cruentam proripis tecum necem?

FIL. MA. Aetate maior ipse te possum sequi,

A lacte matris paene depulsus puer

Hic te sequetur? Voce qua patrem potes

3440 Retinere, retine frater optantem mori.

FIL. MI. Pater, pater, cur pergis ad mortem, pater?

R. Fili, uolebam, paruule, in tanto mori

Rerum mearum turbine; aetatem tuam

Fratrisque sed quis alter aspiciet pater?

3445 Ciuisne an hostis? Tempore o tali graue

Habuisse tales liberos ! Forma incliti

3412 Cur] Quis KCT 3417 eras, semel ante fidem $K \quad \mathbf{3 4 1 8}$ Cautus] Semel KCT 3420 capta] rapta $L \mathbf{3 4 2 2}$ flammas $T$ / raptor - domos] spoliat ardentes domos KCT 3429 ruit $m g$. Cx 3430 excissae $L \mathbf{3 4 3 1}$ Patriae] Solymae KCT / Absit mg. Cx $\mathbf{3 4 3 2}$ Solymaeque] 
É nisto, afinal, que dá o poder?

É este o fim que os pesados ceptros me reservam, a mim, o rei?

Onde estou? Que fiz? Para onde me arrastam? Para onde me empurra

o destino? Porque me fez sentar num trono dourado,

cheio de ilusões? Deuses do céu, vejo a cidade a arder,

repleta de fogueiras. Deita fumo a glória dos filhos de Isaac,

o templo; de seus santuários sobem novelos de faúlhas,

e esta ruína é o prémio do meu crime.

Poderia ter tomado providências se, precavidamente, tivesse escutado

o santo profeta. Porque desprezei as ameaças de Deus?

Elas transformaram-se em verdadeiras punições. Os soldados

caldeus ocupam vitoriosos a cidade e, de forma bárbara,

massacram ferozmente quem não conseguiu fugir.

Por entre as chamas, ladrões assaltam as residências.

Porque estás ansiosa, minha alma? Consegues ver esta chacina? ${ }^{23}$

Afasta a dor, vai em frente, mereceste, morre.

Que a pátria, ao cair, me cubra nos seus escombros.

Que a pátria amortalhada seja a minha mortalha.

Filho MAIS VElHo - Eu já não reclamo os ceptros perdidos, meu pai;

é por ti que pedirei. Foge da morte enquanto podes.

REI - Pedes por mim, filho querido? Por culpa minha, Jerusalém

caiu incendiada. Levar-me-ão como a testemunha que resta

da pátria destruída. Não, irei ao encontro do meu destino

e do de Jerusalém, e antes que me façam prisioneiro, voluntariamente

estenderei meu pescoço ao vencedor que me procura.

FilHo MAIS NOVO - Ó meu pai, para onde te conduz essa insensata

loucura? Deixas teus filhos órfãos de pai

ou arrasta-los contigo ao encontro de morte sangrenta?

Filho mais velho - Eu, que sou o mais velho, poderei seguir-te.

Mas esta criança, ainda há pouco arrancada ao seio materno, seguir-te-á? Ó meu irmão, com as palavras de que fores capaz, demove teu pai da vontade de morrer.

Filho MAIS NOVo - Papá, papá, porque vais ao encontro da morte?

REI - Meu pequenino, o meu desejo era morrer nesta tormenta

que assola a minha vida, mas que outro pai

olhará pela tua vida e pela de teu irmão?

Um cidadão ou um estrangeiro? Oh! em situações destas,

como é terrível ter tido filhos! De nobre beleza,

« Patriaeque KCT / capiar] quaerar KCT 3434 Quo caecus ire pergit $K C T \mathbf{3 4 3 5}$ reliquis $K$ 3437 Fil. Ma. Om. $K C T \mathbf{3 4 3 8}$ lact $L$ / mater eras. et matris $m g$. $C x \mathbf{3 4 4 1}$ cur] quo $K C$ 3444 adspiciet] accipiet $C T$ occupat $K$ 
Vultu decori, regia nati indole

Cui uos relinquam?

FIL. MA. Nemini, at serua tuos.

\section{Godolias, Rex, Phassvrvs}

GOD. Occidimus, occidimus.

R. Mea ut praecordia

3450 Transfigit ille clamor! O mea pignora, Vbi collocabo? tuta quo ponam loco?

GOD. O Rex per urbem flamma populatrix uolat

Deus ad Tyrannum transtulit Babylonium

Omnia. Sepulta gloria Isacidum iacet.

3455 R. Cur sola fumat Solyma? cur patriae cinis

Abominando cinere non crescit meo?

PH. Paueo, fatisco, clade Solymorum ruo.

O Caelites! O astra! Quid demens fleo?

Quae segnis ista teritur ad muros quies?

3460 Post terga clamor hostium dirus fremit.

Seruet salutem perdito regno fuga.

R. Horum tenella capita seruentur; meum

Fortuna dira sorte qua cepit, ferat.

Parui citate liberi imbellem gradum.

3465 GOD. Tollantur umeris. Tollo maiorem; tibi, Phassure, ne sit sarcina hic alter minor.

Eia, fugiendum; tempus hoc odit moras.

\section{NABVZARDANVS capta urbe}

NABVZ. Vrbem tot annis gentis inuisam malae

Tandem potenti dextera euerti. Bene est.

3470 Exusta miles tecta Chaldaeus rapit,

Princepsque uotis potitur Assyrius suis.

Vix temperare gaudio ingenti queo;

Vix ira talem sistit in gentem impetum.

Sanguine cruentae noxio manant uiae.

3450 Transfigit] Agitauit $K C T 3451$ Cui (Vbi $K$ ) uos relinquam $K C T 3452$ populatrix] succensam KCT 3455 post Solyma] nec mecum perit KCT 3456 om. C 3457 ruo] graui KCT 3463 post qua] uellit auferat $K C T \mathbf{3 4 6 6}$ Phassure fiat sarcina haud grauis minor KCT 
de rosto encantador, nascidos para serdes reis,

a quem vos entregarei?

Filho mais velHo - A ninguém. Conserva-nos contigo.

\section{CENA V: Godolias, Rei, Fassuro ${ }^{124}$}

Godolias - Morremos, morremos!

REI - Oh! Atravessam-me as entranhas

aqueles gritos! Ó meus filhos, onde vos colocarei?

3450

Onde vos porei em segurança?

Godolias - Ó rei, um incêndio devastador propaga-se pela cidade.

Deus transferiu tudo para o tirano da Babilónia.

A glória dos filhos de Isaac jaz por terra.

REI - Porque arde apenas Jerusalém? Porque não se juntam

às cinzas da pátria as minhas cinzas abomináveis?

FASsuro - Tenho medo, sinto-me desfalecer, sou arrastado na queda de Jerusalém. Ó deuses do Céu! Ó astros! Porque choro como um louco?

Que calma apática é esta que se passa junto às muralhas?

Na retaguarda soam os gritos terríveis do inimigo.

3460

Já que o reino se perdeu, que a fuga me garanta a vida.

REI - Poupem as tenras vidas destes; quanto à minha,

leve-a a cruel fortuna com o destino que lhe aprouver.

Meus pequeninos, apressai esses passinhos delicados.

Godolias - Levemo-los aos ombros. Eu levo o mais velho, Fassuro; 3465 assim, este mais novo não será grande peso para ti.

Vamos, há que fugir; não é altura para demoras.

\section{CENA VI: NABUZARDANO, após a tomada da cidade ${ }^{125}$}

Esta cidade de gente malvada, que há muito eu detestava, conquistei-a, finalmente, com minha poderosa dextra. Tudo em ordem!

Os soldados caldeus saqueiam as casas queimadas

e o Príncipe assírio é senhor dos seus desejos.

A custo consigo conter minha enorme alegria;

a custo minha cólera sustém tamanho arrebatamento.

As ruas estão alagadas de sangue criminoso.

$\longleftarrow 3467$ fugiendum] mora nulla $K C T \mathbf{3 4 6 8}$ malae] impiae KCT $\mathbf{3 4 7 2}$ temperari $K \quad \mathbf{3 4 7 3}$ sistit] sistere $K C T$ / ingentem $L$ / impetum] potest $K C T \mathbf{3 4 7 4}$ manent E 
3475 Cadaueribus oppleta maerent ardua

Culmina domorum, caede nec tanta manus

Saturata parcit, gliscit in caedes nouas

Capulum retentat ensis, et queritur parum

Fusum cruoris. Debuit Hebraeum genus,

3480 Id est, propago gentium deterrima,

Radice nulla uiuere, at radicitus

Caedente ferro, et igne populante erui.

Vicina magno qualis Euphrati iuga

Leo colit asper, quem sacra armentum fames

3485 Laniare cogit, ungue cum tauros ferox

Euiscerauit, uentre iam pasto satur

Libido nondum cessat, et plures sibi

Vitulos minaci dente mactari iubet,

Ita caede fessus plurima miles furit,

3490 Adhuc calentem pectoribus iram tenet.

Sed plena nondum fulsit e caelo aurea

Victoria; deest magna laetitiae mihi

Pars una. Fugit ille Sedecias erat

In quo triumphus additus uictoriae.

3495 Ne me ante patrii facite uictorem Dei,

Quam captus hostis sub iugo collum terat

Princepsque noster calcet abiectum pede.

\section{NABVZardanvs. Neregel. RABSACES}

NABVZ. Ades, o Neregel, ostia urbis occupa

Durisque turbam uinculis captam liga.

3500 Accerse regem nuntiis, uictoriam,

Vrbem occupatam, incendio euersam doce.

Cum prole patrem et ducibus abeuntem sequar.

O me ducem et mortalium excelsissimum

Regem fugacem si fuga elapsum assequar.

3505 Me peruolantem milites sequimini.

NER. Felicitatis praepes ad metam uola.

O fide tantae gloriae et pompae comes,

Amice care Rabsaces. Per quem inclitus

[p.122]

$\mathbf{3 4 7 6}$ neque $K C T \mathbf{3 4 7 7}$ parcit] cessat $K C T \mathbf{3 4 7 8}$ queritur $C x$; quaeritur $C \mathbf{3 4 8 0}$ teterrima $K \mathbf{3 4 8 2}$ Caedente ferro] Ferro necante $K C T \quad \mathbf{3 4 8 3}$ Euphratri $C$ Euphratis $L \mathbf{3 4 8 5}$ Laniare cogit] Lacerare iussit KCT $\mathbf{3 4 8 8}$ minace $C E \mathbf{3 4 9 0}$ ante calentem] Et adhuc KCT 3492 mihi] 
As elevadas moradias, repletas de cadáveres,

3475

choram o seu luto, e as mãos não param,

saturadas de tanta matança: avançam para novas chacinas,

seguram o punho da espada, pouco se importando

com o sangue derramado. A raça hebreia, a pior de todas as raças,

estava destinada, não a viver sem qualquer raiz,

3480

mas a ser completamente destruída

pela espada e por chamas devoradoras.

Tal como o leão furioso que habita os montes, ${ }^{126}$

junto ao grande Eufrates, a quem fome violenta

fez dilacerar um rebanho, após desventrar com fúria

3485

os touros com as unhas, já com o ventre saciado,

não vê ainda acalmada a sua avidez e teima

em matar vários vitelos com seus dentes terríveis:

também os soldados, cansados de tanta chacina,

conservam ainda a fúria acesa em seu peito.

3490

Mas a áurea Vitória ainda não brilhou em pleno

no céu; falta-me só um quinhão razoável,

o maior da minha alegria. Sedecias fugiu.

Nele residia o triunfo a acrescentar à vitória.

Não me considereis vencedor, deuses pátrios, sem que o inimigo,

3495

aprisionado, vergue seu pescoço sob o jugo

e o nosso imperador o humilhe, espezinhando-o com os pés.

\section{CENA ViI: NabuZardano, Neregel, Rabsaces}

NABUZARDANo - Vem cá, Neregel; ocupa as entradas da cidade

e liga com fortes amarras a multidão dos cativos.

Envia mensageiros ao nosso imperador e informa-o da vitória,

3500

da ocupação da cidade e da sua destruição pelas chamas.

Eu irei no encalço do pai em fuga com os filhos e seus generais.

Oh! Serei um grande general e o mais famoso dos mortais

se alcançar o rei fugitivo que se me escapou.

Segui-me, soldados, a toda a velocidade.

Neregel - Voa como um pássaro para a meta da felicidade,

ó fiel companheiro de tanta glória e majestade,

caro amigo Rabsaces. Quem, melhor do que tu,

« meae KCT 3494 post triumphus] gloria et uictoria KCT 3498 urbis] magnanime KCTE 3499 alliga $K C T \quad \mathbf{3 5 0 4}$ fugacem] fugarem $L \quad \mathbf{3 5 0 5}$ Me habete celeri milites passu ducem KCT 3506 om. KCT 3508 care] clare $L$ / Rabsace KCT 
Nabucdonosor melius agnoscet sui

3510 Iam iuris esse tecta Solymorum ardua

Referente quam te? Peruola cursu celer,

Dominum morantem pete Reblatano in solo.

RAB. Colis colentem Rabsacem. Pernix uolo.

Docebo regem quem triumphantem sequi

3515 Per te Neregel Rabsaci datum est tuo.

NER. Sedate fletum, turba captiua, interim

Porrigite uinclis bracchia. In collo aeneae

Rigeant catenae.

\section{Neregel. Hieremias}

NER. Cerno quem uinctum senem?

Me cana flectit barba, me crines mouent

3520 Orisque maeror ille uenerandi trahit.

Grandaeue quisquis captus es, uultu graui

Me flectis hostem. Ceteros Solymos fuit

Vicisse gratum, te tamen uiso dolet

Vicisse pectus. Fare quo natus loco,

3525 Qua tanta clades sorte te deiecerit?

H. Non huius urbis prima me clades grauat.

Maior grauabat antequam Solymae erutae

Vestra patefactas arma rupissent fores.

NER. Occulta quae me causa conciliat tibi?

3530 Rerum tuarum prome fortunam, pater.

H. Captiua de me turba testari potest.

NER. Alios omitte; te uolo testem tui.

H. Deus ille cuius numine hoc regnum stetit,

Olim tot annos, scelera detestans, suum

3535 Populum sub hoste cadere Chaldaeo dedit.

Stragem monebat ore uenturam meo.

Nec Rex, nec ipsi Principes uero fidem

Habuere uati. Mille quin ideo malis

Affectus, imo carcere, et barathri lacu

3540 Virgisque poenas caesus indignas dedi.

NER. Et non mouebat urbis huius incolas

$\mathbf{3 5 1 1}$ celer] alite KCT $\mathbf{3 5 1 3}$ Colis ut colit te Rabsaces. Citus euolo KCT $\mathbf{3 5 1 5}$ eras. Rap ante Rabsaci / est datum KCT $\mathbf{3 5 1 7}$ Porrigite] Eia date KCT / uinculis $L \mathbf{3 5 1 8}$ uictum $K$ 3521 Grandaeue traheris quisquis hoc uultu senex $K C T \mathbf{3 5 2 2}$ Ceteros Solymos] ceteram turbam KCT $\mathbf{3 5 2 5}$ ante tanta] sorte eras. et sorte s. u. / Qua sorte clades tanta KCT 
poderá anunciar ao ilustre Nabucodonosor

que os elevados palácios de Jerusalém já se encontram

sob a sua autoridade? Corre rápido junto do nosso soberano,

sediado em terras de Reblata. ${ }^{127}$

RABSACES - Tu honras quem te honra. Parto sem demora.

Informarei o imperador sobre quem segue triunfante,

conforme referiste, Neregel, ao teu amigo Rabsaces.

3515

NEREgel - Reprimi o choro, prisioneiros, e entretanto

estendei os braços para as algemas; que cadeias de bronze

vos apertem o pescoço.

\section{CENA VIII: NEREgEL, JEREMIAS 128}

Neregel - Aquele ancião amarrado, quem é?

Enternece-me sua barba branca, impressionam-me seus cabelos

e a aflição estampada no rosto deixa-me curioso.

3520

Sejas quem fores, ó ancião, pela nobreza de teu rosto

impressionas quem é teu inimigo. Foi-me grato vencer

os outros habitantes de Jerusalém, mas tendo reparado em ti

dói-me ter-te vencido. Diz-me onde nasceste

e que grande desgraça te colocou nesse estado.

3525

JEREMIAS - Não é a destruição da cidade o que mais me aflige.

Afligia-me mais antes de vossas tropas terem arrombado

e deixado escancaradas as portas de Jerusalém em ruínas.

Neregel - Que motivo oculto me faz simpatizar contigo?

Conta-me tuas desditas, meu pai.

3530

JEREMIAS - A multidão dos cativos poderá testemunhar a meu respeito

Neregel - Deixa os outros; quero que sejas tu a falar de ti.

JEREMIAs - Deus, por vontade de quem este reino subsistiu

tantos anos no passado, aborrecido com os crimes de seu povo

permitiu que este caísse sob o jugo do inimigo caldeu.

Eu avisava-o, em discursos, do morticínio que adviria.

Nem o rei, nem os próprios nobres deram ouvidos

ao verdadeiro profeta. Mais: sofri, por isso, inúmeras desgraças.

Fui castigado infamemente no fundo do cárcere

e no lago do báratro, após me chicotearem com vimes.

3540

Neregel - E o respeito devido a esses cabelos brancos

— 3526 urbis huius $K C T$ / eras. .... ante grauat $\mathbf{3 5 2 8}$ patefactus $L$ / rupissent] pepulissent Cs.u.KT $\mathbf{3 5 2 9}$ consiliat KCL $\mathbf{3 5 3 0}$ prome E1; prope $E \mathbf{3 5 3 2}$ te tui testem uolo KCT 3535 dedit] tulit $K C T \quad 3537$ ipsi] ulli $K C T$ ne ipsi $L \quad \mathbf{3 5 4 1}$ huius] inimicae $K C T$ 
Reuerentia albi capitis? O gentem feram!

Vatine nomen est Hieremiae tibi?

H. Est, et fuisset agnitum o utinam meis.

3545 Sed laeua mens, abrepta uanis fraudibus

Vatum malorum, damna non uidit sua.

NER. Agnosco tantae cladis insontem senem.

Quis nunc ad urbem properat armorum globus?

Tremendus urbis uictor ac orbis uenit.

\section{NABVCDONOSOR}

3550 NABVC. Parem Tonanti me Deo factum puto

Ipsumque mecum sceptra partitum reor.

Capit regenda culmina polorum sibi,

Frenare terras linquit imperio mihi.

Nunc uera regni sceptra Chaldaei gero.

3555 Hodie meorum summa uotorum attigi.

Cecidit superba Solyma. Fumanti rogo

Adhuc relucet. Restat ut belli inclitam

Iustamque uicto lauream a populo feram.

Adhuc calentes igne praeterito domos

3560 Igne renouato ardere mandabo; eruam

Ab stirpe muros, ne qua memoria impiae

Supersit urbis, tecta tectis addita

Murique muris desuper lapsi cadant.

Non hic ab ortu flammifer Titan suo

3565 Properans in alto condere quadrigas freto,

In itinere urbem cernet et superis Deis

Et mihi molestam. Pereat, aeternum occidat

Ipsosque cineres aeneo inclusos cado

Sodomae et Gomorrhae pigra suscipiat palus.

3570 Tali sepulcrum tale debetur tibi,

Solyma, tuisque. Non parentari loco

Honestiore uel magis casto potes.

Adeste nostri nobiles regni Duces

Tuque o Neregel. Video fumantem nigra

3575 Solymam fauilla; capita Solymorum expedi.

3542 O gentem feram eras. et $m g$. Cx 3543 Nomenne uatis KCT $\mathbf{3 5 4 8}$ eras. Sed ante Quis / Sed quis ad urbem graditur armorum globus? KCT 3549 Tremendus orbis ecce dominator uenit CT om. K 3552 Sibi polorum culmina regenda accipit KCT 3553 liquit $K$ 
não demovia os habitantes desta cidade? Ó gente selvagem!

Não te chamas Jeremias, o profeta?

JEREMIAS - É verdade, e oxalá meus concidadãos me tivessem reconhecido.

Mas sua mente insensata, arrastada pelas vãs artimanhas 3545

dos falsos profetas, não se deu conta dos perigos que corria.

Neregel - Vejo que o ancião não é culpado de toda esta desgraça.

Que grupo compacto de soldados se dirige para a cidade?

É o temível vencedor da cidade e do mundo que chega.

\section{CENA IX: NABUCODONOSOR ${ }^{129}$}

NABucodonosor - Considero-me igual ao Deus tonante

e julgo mesmo que Ele repartiu comigo seu poder.

Para si Ele reserva o domínio do firmamento;

a mim, concede-me governar a terra.

Agora empunho verdadeiramente os ceptros do reino caldeu.

Hoje atingi a realização plena dos meus desejos.

3555

A orgulhosa Jerusalém caiu. Ainda reluz

como pira fumegante. Resta-me recolher do povo vencido

os nobres e justos louros da guerra.

As casas ainda quentes dos incêndios extintos

mandá-las-ei atear de novo; arrasarei

3560

as muralhas pela base, para que não subsista memória alguma

da ímpia cidade. Desmoronem-se as casas, umas sobre as outras,

e arrasem-se muralhas atrás de muralhas.

O Titã portador da chama, ao viajar,

Com suas quadrigas, do nascente ao poente, em alto mar, ${ }^{130}$

não verá aqui esta cidade odiosa aos deuses

e a mim. Que morra, que desapareça para sempre

e que o pântano estéril de Sodoma e Gomorra

recolha suas cinzas num vaso de bronze.

Por seres assim, eis a sepultura que te é devida,

Jerusalém, a ti e aos teus. Não podes ser honrada

com local mais condigno ou mais puro.

Aproximai-vos, ilustres generais do nosso reino,

e tu, Neregel. Vejo Jerusalém fumegando

no meio de negra cinza; põe em fila os habitantes de Jerusalém.

$\longleftarrow 3555$ notorum $L \quad 3556$ Fumanti rogo] fumante halitu KCT $\mathbf{3 5 5 7}$ relucet] uaporat KCT 3562 addita] corr. ex. additis $E$ additis KCT 3563 muros $T 3568$ inclusos] lectos $K C T$ 3570 tali $K \quad \mathbf{3 5 7 1}$ Solimae $L$ 
Rape, miles, ensem, uictimae fiant mihi

Nostroque fuso sanguine furori litent.

Regem exhibete. Quae mora? Aspectum suo

Satiet cruore perfidus. Poenas luat.

3580 NER. Dum capta propugnacula tui milites

Virtute noti scanderent et obuios

Formidolosa strage mactarent uiros,

Iactisque templum facibus auratum urerent, Inter tumultum euasit occulta fuga.

3585 NABVC. O nulla neque parta, neque grata gloria.

Victoria, o Victoria inuisa es mihi.

Quando hostis ille primus, et uerus meas

Euasit iras. Saxa quid prosunt truci

Liquefacta flamma? quid solo aequatae domus?

3590 Istaecne dextrae sentiunt pondus meae?

Quibus creatis ducibus infausto alite

Mea bella gessi? Vos ego statui duces,

Vita ut Tyrannus fugeret incolumi procul?

Proferte saltem capita natorum duo.

3595 Cessatis? Ecquid liberos secum tulit?

NER. Cum patre fugit tota progenies suo.

NABVC. Ignaui, inertes, penitus armorum rudes,

Odiique nostri. Quomodo ulciscar meum

Hostem fugacem, fugere si sinunt mei?

3600 Lubet ob dolorem pectus agitantem mori,

Aut uos Tyranni pro capite transfigere.

Vtinam ligatum prole cum tota patrem

Possem intueri. Caelites testor deos:

Non ante uisam tecta Babylonis meae,

3605 Quam proferatur stirpe cum tota pater.

NER. Aequate, Domitor orbis, aetheriis deis.

Vix Solyma primas sensit iniectas faces,

Cum Rex Hebraeus fugit occulto ostio.

Fugientis at uestigiis mox institit

3610 Ille legionum dux et armorum decus.

Praesentit animus Rege captiuo tamen

Iam iam daturum lauream belli tibi.

Collecta numero turba non paruo est mihi.

3578 eras. regem post exhibete / Regem exhibete] Date, date regem KCT 3580 capta] rupta $K C$ rapta $T 3581$ noti s. $u$. $C \quad 3585$ Nab. pers. $E$ Nabuzardanus pers. $L \quad 3588$ Saxa] Sacra $L 3591$ Quibus] heu $a d d$. KCT 3595 om. K 3596 tota] rapta KCT 3597 Nab. pers. $E$ Nabuzardanus pers. $L 3598$ nostri] iusti KCT 3601 nos $L 3605$ proferatis $K C T$ proferantur 
Soldados, puxai da espada, fazei-me vítimas

e aplacai minha fúria com derramamento de sangue.

Trazei-me o rei. Porque tardais? Sacie o traidor seu olhar

no sangue de sua gente. Pague o que merece.

Neregel - Enquanto teus soldados, de reconhecida coragem,

3580

tomavam de assalto os baluartes e abatiam

quantos encontravam à sua frente, numa chacina terrível,

e incendiavam o templo dourado arremessando archotes,

o rei fugiu, disfarçado por entre a confusão.

NABUCODONOSOR - Ó glória nula, não obtida, não agradável.

3585

Vitória, és-me odiosa, ó Vitória,

pois meu principal e verdadeiro inimigo

furtou-se à minha cólera. Para que servem pedras derretidas

pelo calor das chamas? Para quê as casas arrasadas?

Sentem estas o peso da minha dextra?

3590

Com que generais, em má hora nomeados,

conduzi eu minhas guerras? Nomeei-vos generais

para que o tirano escapasse para longe, são e salvo?

Trazei ao menos à minha presença os seus dois filhos.

Ficais parados? Será que ele levou consigo os filhos?

3595

NEREgEL - Toda a prole fugiu com o pai.

NABucodonosor - Preguiçosos, inertes, totalmente ignorantes

da guerra e do nosso ódio. Como me poderei vingar

do inimigo em fuga, se os meus consentem que ele fuja?

Apetece-me morrer, tal é a dor que sacode meu peito,

3600

ou então trespassar-vos a vós, em troco da cabeça do tirano.

O pai algemado, em companhia de toda a prole,

quem me dera poder vê-lo. Os deuses do Céu são testemunhas:

não verei os Lares da minha querida Babilónia

sem antes me apresentarem em público o pai e toda a sua estirpe.

3605

Neregel - Ó soberano de toda a terra, igual aos deuses.

Mal Jerusalém sofreu o efeito do arremesso das primeiras tochas,

Logo o rei hebreu fugiu por secreta passagem.

Sem demora, lançou-se no encalço do fugitivo

o comandante das legiões e a glória do nosso exército.

3610

Tenho um pressentimento de que, aprisionado o rei,

não tardará muito a entregar-te os louros da guerra.

Reuniram-me uma multidão razoável de gente.

$\longleftarrow$ L / patrem KCT 3606 eras. ae.er post Orbis / aetherii $T 3609$ Fugientium uestigiis sed institit $K C T$ / at] ac $L \mathbf{3 6 1 0}$ Nabuzardanus ille, militiae decus KCT $\mathbf{3 6 1 1}$ eras. tibi ante tamen] tibi KCT $\mathbf{3 6 1 2}$ tibi] inclitam $K C T$ 


\section{Neregel. Hieremias. NABVCDONOSOR}

NER. Sed ante ceteros uide egregium senem

3615 Vatem Tonantis. Ille non cladem semel

Praedixit, ille bella, numquam creditus

Dissuasit auctor. Respice et, siquid preces

Valent tuorum, da mihi hunc saluum senem.

H. Licet inter arma dura, licet inter rogos

3620 Patriae et acerba funera meorum, licet

Tecumne Rege pauca captiuo loqui?

O magne princeps, splendidum terrae iubar.

NABVC. Tibi licet uni. Postula Regem, senex.

H. Dominator orbis magne, uicisti. Tuum est

3625 Possedit olim quicquid Isacidum domus.

NABVC. Leuate ab ima nobilem terra senem.

H. Deus ille magni conditor Olympi tibi

Seruire Solymam gente cum nostra dedit,

Infanda propter scelera. Sed regem decet

3630 Lenem parumper tollere in uictos manum.

NABVC. Ne metue, uates sancte, nam parco tibi

Docturus alios, quid sit imperium pati

Quidque mereantur qui datam rumpunt fidem.

H. Per tua rogabo sceptra, ne nimium uelis

3635 Victoris uti iure. Nam quo te altius

Erexit Ille, qui solet sceptrum dare,

Hoc te magis reprimere fortunam decet.

Opulenta paruo regna momento obrui

Vincendo disce. Solyma nos miseros facit.

3640 At te beatum. Victor illo stas loco

Vnde illa cecidit. Quicquid euersae potest

Superesse Solymae, maneat. Hoc unum rogo.

NABVC. Haec postulabis? Non tibi in mentem uenit

Quid promeruerit Solyma? Quid gens perfida?

3645 Bis capta, bis dimissa renouauit graue

Longumque bellum. Si modo exarsit, suis

[p.127]

Exercita furiis aluit incendium;

Vetante caelo, uate te uero et bono

Prohibente, facta est hostis et mihi et Deo.

$\mathbf{3 6 1 4}$ egregium] aetherium KCT $\mathbf{3 6 2 0}$ et acerba] reuulsae et $K C T \mathbf{3 6 2 1}$ Rege] uati KCT 3623 post licet] ecquid postulas KCT 3625 domus] genus KCT $\mathbf{3 6 2 7}$ magni] nitidi $K C T$ 3633 Et non sacrilega abrumpere fidem audacia $K C T \mathbf{3 6 3 6}$ Erexit] Euexit ille regna qui solet 


\section{CENA X: Neregel, Jeremias, NABUCOdonosor ${ }^{131}$}

NEREGEL - Mas antes que repares nos outros, repara num venerável ancião, o profeta do Tonante; por mais de uma vez, ele predisse esta desgraça, desaconselhou a guerra, mas nunca lhe deram crédito.

Pensa bem, e se os pedidos de quem te serve têm algum valor, poupa-me este ancião.

JEREMIAS - Entre soldados hostis, vendo a pátria a arder e a triste morte de minha gente, permitirão a um prisioneiro que fale um pouco contigo, que és rei, ó magnânimo imperador, majestade esplêndida da terra? NABUCODONOSOR - Só a ti te é concedido. Faz um pedido ao rei, ancião. JEREMIAS - Grande soberano de toda a terra, tu venceste. É teu tudo o que a terra dos filhos de Isaac outrora possuiu.

NABUCODONOSOR - Erguei do solo o nobre ancião.

Jeremias - O Deus criador do majestoso Olimpo permitiu que Jerusalém e o nosso povo se colocassem ao teu serviço, por causa de seus abomináveis crimes, mas fica bem a um rei estender por momentos aos vencidos sua mão indulgente.

NABUCODONOSOR - Não receies, venerando profeta; a ti poupar-te-ei, mas aos outros ensinar-lhes-ei o que é sentir o peso da autoridade e o que merecem os que faltam à palavra dada.

JEREMIAS - Pelos teus ceptros rogar-te-ei que não consintas em abusar do direito de vencedor. Na verdade, quanto mais alto te colocou Aquele a quem é dado atribuir os ceptros, mais te convém a ti conter a fortuna. ${ }^{132}$ Grandes impérios em breves instantes se desmoronam. Aprende isto ao vencer. Jerusalém faz-nos infelizes.

Mas feliz és tu que te ergues vitorioso 3640 onde ele foi destronado. Tudo o que puder subsistir da destruição de Jerusalém, que subsista. É só o que te peço. NABUCODONOSOR - É isto que me pedes? Não te ocorre o que merece Jerusalém? O que merece esta pérfida gente? Duas vezes conquistada e duas vezes perdoada, reiniciou longa e perigosa guerra. Se há pouco ardeu, quem alimentou o incêndio foi ela, levada por suas loucuras. Com a oposição do céu e a tua proibição de verdadeiro e bom profeta, ela tornou-se inimiga tanto de mim como de Deus.

« dare KCT 3638 Opulenta] Tremenda KCT 3640 At] Et KCT / post beatum] sistis hoc uictor KCT 3641 illo $L \quad 3642$ unum] uictus KCT 3643 postulabis ? non] deprecaris nec KCT $\mathbf{3 6 4 4}$ post Solyma] cum gente impia? KCT $\mathbf{3 6 4 6}$ post bellum] Quid queror? Si ardet sibi KCT 
3650 H. Satis cremata patria poenarum dedit.

NABVC. Gradus est futuri poena supplicii tulit

Quam Solyma. Grauius ultor in Solymam paro.

H. Aliquidne grauius uictor in uictos potest?

NABVC. Quod ira uictos promere in tales iubet.

3655 H. Est regis ipsos premere captiuos minus.

NABVC. At praepotentem frangere superbos decet.

H. Non sunt superbi quos ita abiectos uides.

NABVC. Fient, misericors parco si genti improbae.

Ingenia noui Regis et gentis tuae.

3660 Tibi reddo uitae spiritum; hunc uates habe.

Permitte reliquos igne uel ferro mori.

Senex abire liber hoc dono potes.

\section{NABVCDONOSOR. Neregel. NABVZardanvs}

NABVC. Ades, o Neregel, ecquis apparet procul?

NER. Ipse est Nabuzardanus incessu mihi.

3665 NABVC. Graditur superbe. Quid tamen secum feret?

NABVZ. Dux fulguranti gradior aequalis polo

Hominesque clarum uerticem attollo super

Deisque factum credo me Superis parem.

Nunc decora belli teneo; nunc uictoriam

3670 Non incohatam uideo, perfectam fero.

Quo peruenire uota potuerunt mea

Hodie attigerunt: prole cum tota patrem

Adduco captum. Quis meas fugiet manus?

Mecum quis hostis conseret dextram ferox

3675 Neque ense nostro caesus aut uictus cadet?

Solymaene Regem tuta seruasset fuga

Me persequente? Latebra texisset caua

Vllane receptum? Si ardui nubes poli

Petiisset ales, inde detractus foret.

3680 Neque terra, neque caelum, neque Oceani uada,

Neque in Acherontis gurgite sepulti inferi

Celare possent. Namque quaesitum darent

Excussa terra, excussa Tartara, excussum mare.

3650 patria] Solyma KCT 3651 tulit] data KCT 3652 om. KCT 3655 ipsos] alti KCT / captiuos] deiectos KCT 3656 At] Et KC 3658 improbae] impiae KCT 3659 post noui] plebis et regis tui $K C T 3662$ om. KCT 3663 post ecquis] quis mouet gressum procul? KCT 3664 Ipso Nabuzardanus incessu patet KCT Ipso Nabuzardanus incessu mihi est $E$ / Ipsumne 
JEREMIAS - Minha pátria incendiada já teve castigo bastante.

NABUCODONOSOR - É parte do suplício futuro a punição sofrida por Jerusalém. Preparo contra Jerusalém suplício mais cruel.

JEREMIAS - Será possível crueldade maior do vencedor sobre os vencidos?

NABUCODONOSOR - O que a cólera manda apresentar a vencidos como estes.

JEREMIAS - É próprio dum rei oprimir pouco os seus prisioneiros. 3655

NABUCODONOSOR - Mas a quem é muito poderoso convém humilhar os soberbos.

JEREMIAS - Não são soberbos os que tu vês em tamanha abjecção.

NABUCODONOSOR - Tornar-se-ão se, compadecido, poupar um povo perverso.

Eu conheço o temperamento do rei e da tua gente.

Restituo-te a liberdade, profeta. Conserva-a. Quanto aos outros, 3660 deixa-os morrer pelo fogo ou pela espada.

Podes ir em liberdade com esta minha dádiva, ancião.

\section{CENA XI: NABUCODONOSOR, NEREgEL, NABUZARDANO ${ }^{133}$}

NABUCODONOSOR - Aproxima-te, Neregel. Quem surge ao longe?

Neregel - Pelo andar, é Nabuzardano em pessoa.

NABUCODONOSOR - Ele avança com majestade. Que novidade trará consigo?

3665

NABUZARDANO - Avanço como um general que subiu ao céu brilhante. ${ }^{134}$

Não só elevo os homens aos píncaros da glória,

mas também considero ter-me igualado aos deuses celestes.

Agora guardo comigo altos feitos militares; agora, não vejo

uma vitória iniciada, mas apresento-a consumada;

3670

meus desejos chegaram hoje até onde

poderiam chegar. Conduzo, sob prisão, o rei

e os seus filhos. Quem poderá escapar de minhas mãos?

Que inimigo poderá lutar ferozmente comigo

sem cair morto ou subjugado pela minha espada?

3675

Uma fuga segura salvaria o rei de Jerusalém

sendo eu a persegui-lo? Algum recôndito esconderijo

o poderia manter oculto? Ainda que se refugiasse sobre as nuvens

do céu, como um pássaro, de lá o arrancaria.

Nem a terra, nem o céu, nem as ondas do mar,

3680

nem os abismos infernais do Aqueronte

o poderiam esconder, pois quem eu procurava, a terra, os Infernos,

o mar mo entregariam, depois de examinados.

« magne domitor accersam iubes add. KCT [trad. "Ordenas que vá ao seu encontro, ilustre soberano?"] 3665 Sine audiamus ante quid secum ferat KCT 3673 manus fugiet meas KCT $\mathbf{3 6 7 4}$ conserat KCT $\mathbf{3 6 7 5}$ cadat KCT $\mathbf{3 6 7 9}$ Petiisset ales] Scandisset atras KCT $\mathbf{3 6 8 1}$ Nec KCT 
Nunc citior Euro nuntius uenio alite

3685 Magnumque Regem quaero Babylonis, prior

Quam laeta de me Fama praeueniens canat.

En ante muros cerno. Quas moras traho?

NABVC. O Dux Nabuzardane, quid portas boni?

NABVZ. Aequate Superis, Domitor Orientis plagae,

3690 Laetare. Crescit laudis immensae decus.

Monumenta iusti maxima triumphi eriges.

Euersa iuris Solyma iam maeret tui.

Regem parentem stirpe cum tota fero.

NABVC. Nunc me beatum caelites reddunt Dei.

3695 Satis est, abunde est. Victor astrorum globos

Tango micantes uertice excelsissimo.

Funere suorum perfidum implebo patrem.

Qua sunt tuenda foedera docebo fidem.

Alis patentem facite telorum uiam,

3700 Media per arma trepidus occurrat mihi.

NABVZ. Decus orbis ingens atque diuinum iubar,

Tete expedi. Captiua reddo corpora.

Celerate, lecti milites, adducite.

Domino exhibete prole cum tota patrem.

3705 NABVC. Pallore maerent ora. Squalenti ut caput

Ceruice fracta nutat! Vt uultus iacent!

NABVZ. Ecquid rebelle pectore infido genus,

Pacis inimicum, Martis ad pugnam rude,

Cognoscis in quem bella uoluisti Deum?

3710 NER. Accede, dominum disce reuereri tuum,

Non sacra rumpere foedera audaci manu.

NABVC. Veniat superbus, sortis oblitus suae,

Maior animo tumente quam uires erant.

Sceleris patrati poena in auctorem cadit.

\section{Rex SEdecias. NABVCDONOSOR}

3715 R. Non deprecabor uictus et captus, mori

Fera quando rerum cogit inconstantia.

En rex ab illo culmine impulsus ruo,

3686 laeta] lata $L \quad 3687$ traho moras? KCT 3691 triumphi] trophaei $K C T \mathbf{3 6 9 3}$ fero] dabo KCT 3694 Dedere tanta quanta potuerunt dare add. KCT [trad. "Deram-me tudo quanto podiam dar."] 3696 Tango] Tanto $K \mathbf{3 6 9 8}$ sint KCT / fide KCT 3699 patentem] parentem $K$ / telorum] protensis KCT $\mathbf{3 7 0 1}$ atque] et $K \mathbf{3 7 0 4}$ Cernisne regem prole cum tota impium? 
Agora, chego como mensageiro, mais rápido que o Euro alado, ${ }^{135}$

e procuro o grande rei de Babilónia, antes que me ultrapasse

e desate a falar a meu respeito a alegre Fama.

Já avisto em frente as muralhas. Porque espero?

NABUCODONOSOR - Que boas novas nos trazes, general Nabuzardano?

NABUZARDANO - Alegra-te, senhor das terras do oriente, igual aos deuses. ${ }^{136}$

Tua imensa glória brilha com mais fulgor.

Erguerás os maiores testemunhos dum justo triunfo.

Jerusalém, destruída, já sofre, queixando-se de tua autoridade.

Trago-te o rei, o pai com os filhos.

NABuCODONOSOR - Agora, sim, os deuses devolvem-me a felicidade.

É quanto basta; é mesmo muito; eu alcanço vitorioso

as esferas brilhantes dos astros com minha mui excelsa cabeça.

Saciarei o pérfido pai com a morte de seus filhos.

Ensinar-lhe-ei com que lealdade se devem respeitar as alianças.

Abri uma passagem entre alas de dardos

e que ele caminhe até mim assustado por entre as armas.

3700

NABUZARDANO - Ó glória imensa e esplendor divino do mundo, prepara-te. Trago-te de volta os prisioneiros.

Apressai-vos, excelentes soldados; trazei-os;

apresentai ao nosso soberano o pai e os filhos.

NABUCODONOSOR - Os rostos denotam tristeza! Como oscilam suas cabeças

3705 sobre pescoços sujos e cansados! Como mostram um semblante abatido! NABUZARDANO - Raça rebelde, de coração traiçoeiro, inimiga da paz, sem experiência das lides da guerra! Acaso conheces

o Deus a quem pretendeste fazer guerra?

Neregel - Aproxima-te. Aprende a respeitar o teu soberano e não a romper atrevidamente alianças sagradas.

NABUCODONOSOR - Que venha esse soberbo esquecido da sua condição, que se arrogou a mais do que lho consentiam suas forças.

A punição cai sobre quem perpetrou o crime.

\section{CENA XII: REI SEDECIAS, NABUCODONOSOR 137}

REI - Vencido e aprisionado, não farei súplicas. Morte inevitável me impõe a cruel inconstância dos acontecimentos.

Eis um rei desapossado à força do seu fausto, ${ }^{138}$

$\longleftarrow$ KCT $\mathbf{3 7 0 8}$ pugnas KCT $\mathbf{3 7 0 9}$ Deum] impia KCT / om. bella $K \mathbf{3 7 1 0}$ Neregel pers. om. KCTE 3711 Non] Neque KCT / foedera rumpere KCT 3712 Nabvc. pers. om. CT / Veni superbe T 3717 ruo] cadit $K C T$ 
Documenta posteris daturus regibus

Pendere regum sceptra momento leui

3720 Neque regna tuto posse stabiliri loco.

NABVC. Ego te docebo regna cur dubio in loco

Male parta nutent. Pessime tyranne omnium

Quotquot fuerunt anteactis saeculis,

Vbi cura iuris nulla, nec regnat Fides,

3725 Instabile regnum pendet et nutans cadit.

Ignaue, iners, imbellis, Hebraeae domus

Extrema pestis, patriae bustum tuae,

Agnoscis in quas ueneris tandem manus?

R. Agnosco Superos esse crudeles mihi.

3730 NABVC. Adhuc superbiam insitam infelix geris?

Humilemque nondum te tuae clades docent

Induere personam? Eia detestabilis

Tua cogitasti scelera perfidiae parens

Impune itura? Iusta nec tandem fore

3735 Haustura poenas numina Deorum graues?

Aut pro deorum uindice potentum manu

Hac non luendum dextera inuicta scelus?

Superbe in ipso pacis oblatae otio,

Timide sub acri Martis illati metu.

3740 Stupescis infans? Fare, responsum dato.

R. Fortuna si me patitur in tanta loqui

Regni ruina.

NABVC. Regni? Et audes insolens

Meminisse regni? Regio sceptro abstine,

Priua corona nobili indignum caput.

3745 Peiore numquam sceptra fulserunt manu,

Scelestiore uel corona uertice.

R. Abicio regnum, sceptra, diadema. Haec tuo

Sub iure ponunt Caelites. Supplex tuis

Accedo genibus turpe nec uictus puto

3750 Fortuna quicquid aspera in uictos iubet.

NABVC. Arcete tactu famuli et accessu procul.

NABVZ. Quid inepte domini prouocas iram tui?

R. Quando hic miseriis cumulus accedit meis

Tenere genua supplicem ut durus uetes

3720 Nec $K$ / loco] toto $K \mathbf{3 7 2 1}$ cur] eras. quam et cur $m g$. quam $K C T$ / in] om. $K$ $\mathbf{3 7 2 2}$ nutent] sistant KCT $\mathbf{3 7 2 5}$ post regnum] nutat et cito excidit $K C T \mathbf{3 7 2 6}$ Hberaeae $L$ 3740 Stupescis infans?] Nihilne faris? KCT $\mathbf{3 7 4 6}$ Neque uiliorem (meliorem $K$ ) regia coronam 
para servir de ensinamento futuro aos reis

de que o poder real está suspenso dum fugaz momento

e de que é impossível manter seguro o poder em situação estável.

NABUCODONOSOR - Eu te ensinarei por que razão o poder

mal adquirido oscila em situação precária. Ó péssimo tirano,

o pior de quantos existiram nos séculos passados.

Onde não impera zelo algum pela justiça, nem a Boa-fé,

o reino permanece oscilante e, oscilando, cai.

3725

Indolente, ocioso, pusilânime, peste mais nefasta ${ }^{139}$

à casa hebreia, sepulcro da tua pátria,

sabes a que mãos acabaste por vir parar? ${ }^{140}$

REI - Reconheço que os entes superiores são cruéis para comigo.

NABUCODONOSOR - Ainda manténs essa arrogância, infeliz?

Teus infortúnios não te ensinam ainda a adoptar

atitudes de humildade? Vamos, pai abominável,

pensaste que teus crimes de traição

continuariam impunes? Que nem sequer te castigariam

com dureza os justos poderes divinos?

3735

Ou que, em vez da mão justiceira dos deuses poderosos,

minha dextra invicta não castigaria teus crimes?

Orgulhoso, ao gozares da paz que te concederam;

tímido, sob o medo terrível da guerra que tens pela frente.

Estás admirado, sem falar? Fala, dá uma resposta.

REI - Se a fortuna consente que eu fale perante tão grande ruína

do reino.

NABucodonosor - Do reino? E ousas, insolente,

lembrar-te do reino? Põe de lado o ceptro real, priva da nobre coroa tua indigna cabeça.

Nunca os ceptros cintilaram em mãos tão indignas

nem a coroa em cabeça mais criminosa.

REI - Renuncio ao reino, aos ceptros, ao diadema. Tudo isto

os Deuses do alto colocam sob teu poder. Abraço teus joelhos

como suplicante, e nem vencido considero vergonhoso

tudo quanto a cruel fortuna impõe aos vencidos.

NABUCODONOSOR - Criados, não o deixeis tocar-me ou aproximar-se.

NABUZARDANO - Porque provocas inoportunamente a fúria do teu soberano?

REI - Quando minhas desventuras atingem seu ponto máximo,

opor-te-ás cruelmente a que me ajoelhe como suplicante

— induit KCT 3750 iubet s. u. K $\mathbf{3 7 5 1}$ famuli tactu KCT 3752 inepte] uicte KCT / Facesse, propius tendere ut iubet, abstine add. KC [trad. "Fica à distância, como ele te impõe; afasta a ideia de te aproximares"] $\mathbf{3 7 5 4}$ Ab osculandis genibus arceri, tuum KCT 
3755 Negesque lacrimis pectus exorabile?

Admitte paruos liberos, aetas facit

Hos innocentes.

NABVC. Nempe te gnatos patre?

Habeo paratam patre te dignam necem.

Me uindicante scelera non dignam minus.

3760 R. Properate, pueri; fundite tenelli preces.

Ante occupate.

Filit Sedeciae. Nabvcdonosor. Sedecias

FI. Plura quo Superi tibi

Dedere magni, magne regnator, preme

Leuius iacentes. Liberis serua patrem

Patrique sobolem. Nulla nobilior solet

3765 Victoria decorare uictorem manu

Quam subleuare quem ipse prostrauit solo.

Redde o parentem liberis, natos patri.

NABVC. Patris pudorem prodit infandum genus.

Ita docuisti filios? Bellum moues;

3770 Damnata caelo tela contempto rapis;

Mihi imperanti moenia recludi obseras;

Ad arma tecum socia Pharaonem trahis,

Atque obstinatis auribus pacem fugis.

Nunc arce belli facibus accensa meis

3775 Et urbe populi sanguine cruenta, mali

Tu causa tanti solus hoc caelum aspicis,

Vitamque poscis ore natorum tibi?

R. O Rex salutem liberi inueniant sibi.

Merui fatebor; dede me solum neci.

3780 FI. Moriamur immo liberi; uiuat pater.

R. Natura pugnat saeua: quod nolo, uolunt.

FI. Moriamur utinam liberi, uiuat pater.

NABVC. Audire natos potius insontes decet

Quam te nocentem. Viue tu; nati occidant.

3785 R. O saeua misericordia! Insontes cadent?

NABVC. Tu uiue, ferro sed tui gnati cadant. 
e negarás ser sensível às minhas lágrimas?

Deixa ir em paz os meus filhos pequenos; a idade faz deles inocentes.

NABUCODONOSOR - São teus filhos e tu és o pai, não é?

Trago preparada uma morte digna do pai que és, e não menos digna de mim, o vingador de teus crimes.

REI - Apressai-vos, meus pequeninos, dirigi-lhe vossas súplicas. Antecipai-vos.

\section{CENA XiII: Filhos de Sedecias, Nabucodonosor, Sedecias ${ }^{141}$}

FilHos - Quanto mais dons os magnânimos deuses te concederam, excelso soberano, tanto mais brandamente oprime os que estão em aflição. Salva o pai, para bem dos filhos, e os filhos, para bem do pai. Nenhuma vitória muito gloriosa costuma honrar mais o vencedor do que, com suas mãos, soerguer quem foi por ele derrubado. Por favor, entrega o pai aos filhos e os filhos ao pai.

NABUCODONOSOR - A abominável descendência revela os sentimentos do pai. Foi assim que ensinaste teus filhos? Provocas a guerra, empunhas as condenáveis armas, desprezando a vontade do Céu. Encerras-me as muralhas, quando te ordenava que as abrisses; induzes o faraó a juntar seus exércitos aos teus e, não dando ouvidos a ninguém, foges da paz. Agora, com a cidadela incendiada pelos meus archotes de guerra e com a cidade alagada no sangue do povo, tu,

o único culpado de tamanha desgraça, ergues os olhos ao céu e, pela boca de teus filhos, pedes que te poupem a vida? REI - Ó rei, sejam poupados meus filhos.

Confessarei minha culpa; dá-me a morte, só a mim. ${ }^{142}$

Filhos - Morramos antes nós, seus filhos; que viva o nosso pai.

REI - A natureza luta cruelmente: o que eu não quero, querem eles.

Filhos - Oxalá morramos nós, teus filhos; que viva o nosso pai.

NABUCODONOSOR - Convirá mais dar ouvidos a teus filhos inocentes, do que a ti, que és culpado. Vive tu; morram teus filhos.

REI - Ó que misericórdia cruel! Os inocentes irão morrer?

NABUCODONOSOR - Tu, vive, mas que teus filhos morram à espada.

« solus] tantae cladis KCT $\mathbf{3 7 7 8}$ O rex om. K $\mathbf{3 7 7 9}$ post fatebor] si probas, mori iube KCT 3781 nolo] uolo $L \mathbf{3 7 8 2}$ utinam] immo $K C T \mathbf{3 7 8 4}$ occidant] cadant $K C T$ 3786-3789: Nati, ut parens in funere suorum trahat - Vitam molestam, caede quem fecit reum KCT 
Id opto uiuas ut tuorum in funere.

R. Vitamne pater in funere suorum trahet?

NABVC. Quia meruisti.

R. Caede quem fecit reum

3790 Defectionis crimen; innocuos precor Relinque pueros.

NABVC. Liberi occisi cadant,

Sed te uidente patre. Stat sententia.

R. Pater uidebit uiuus occidi suos?

NABVC. Haud usitatum reddo si poenae genus,

3795 Non usitati criminis plecto reum.

Mutas colores oris? Inueni modum

Vltricis irae. Feceram uindex minus

Nisi sic doleres. Lateris o custos mei,

Generose ductor, urbis euersor, fide

3800 Clara Nabuzardane semper cognite

Pueros trucida. Scinde ceruicem patre

Vidente; proles spectet interitum suae.

R. Quid liberi meruere?

NABVC. Quod uiuunt tui.

NABVZ. Accede fide miles, ad tentorium

3805 Rape hosce pueros. Sequere Sedecia pater; Sanguine tuorum iam tuum implebo sinum.

Age, miles, ecquid torpet in caedem manus?

R. Adeste, gnati; nulla ab amplexu auferet

Vos uis Tyranni. Stringite paternos sinus.

3810 Moriamur omnes. Cur iubes pueros mori, Chaldaea tigris? Sanguinem patris bibe.

Cruore seda postea innocuo sitim.

NABVZ. Age, redde. Reddes quando? Cruciatus dabis

Dare quod recusas.

R. Morte quod quaeris dabo.

3815 NABVC. Viuens uidensque redde, nam mortem tibi

Scio esse uotum. Quid trahis longas moras?

Occide miles.

R. Sustines tantum nefas?

Spectasne, mundi Rector, et mutus siles?

Neque fulminante de polo horrificum tonas?

3791 Nab. Viue tu, nati cadant KCT 3792 post. uidente] cerne natorum necem KCT 3793 om. KCT 3794 si poenae] poenarum KCT 3795 Inusitatae plecto te culpae reum KCT 3797 post feceram] hac dextra minus KCT $\mathbf{3 8 0 1}$....ida $C \mathbf{3 8 0 2}$ V...... C / post Vidente] prolem 
Decido assim para assistires com vida ao funeral de teus filhos. ${ }^{143}$ REI - O pai arrastar-se-á vivo no funeral de seus filhos?

NABUCODONOSOR - Assim o mereces.

REI - Mata quem é culpado

do crime de deserção, mas poupa estas crianças, suplico-te;

3790 estão inocentes.

NABUCODONOSOR - Que os filhos caiam mortos, mas na presença do pai. Está dada a sentença.

REI - O pai verá em vida matarem-lhe os filhos?

NABucodonosor - Se determino um tipo de pena pouco usual, ${ }^{144}$ é porque castigo o réu de um crime também pouco usual.

O teu rosto muda de cor? Encontrei a justa medida

da ira justiceira. Ter-me-ia mostrado menos cruel

se não te lamentasses assim. Ó meu ajudante de campo,

excelente general que destruíste a cidade, Nabuzardano,

sempre conhecido por notável lealdade,

3800

degola as crianças. Corta-lhes a cabeça à vista do pai;

que ele contemple a morte de sua prole.

REI - Que mal fizeram meus filhos?

NABUCODONOSOR - Viverem e serem teus filhos. ${ }^{145}$

NABUZARDANO - Aproxima-te, soldado fiel; arrasta

estas crianças para a tenda. Sedecias pai, segue-os.

3805

Eu ensoparei, não tarda, tuas vestes no sangue de teus filhos.

Vamos, soldado, por que esperas para iniciar a matança?

REI -Vinde cá, filhinhos; não vos arrancará de meus braços

violência alguma do Tirano. Apertai-vos contra o peito de vosso pai;

morramos todos. Porque exiges a morte das crianças,

3810

tigre da Caldeia? Bebe o sangue do pai.

Acalma depois a sede com o sangue dos inocentes.

NABUZARDANo - Vá, entrega-mos. Quando os entregarás? À força

de torturas entregarás o que agora me recusas.

REI - Só morto te darei o que me pedes.

NABUCODONOSOR - Entrega-os vivos e a ver; que teu desejo é morrer

sei-o bem. Porque demoras tanto tempo?

Mata-os, soldado.

REI - Proteges crime tão hediondo?

Contemplas e ficas calado, Soberano do universo?

Não fazes cair do céu um raio fulminante?

« cernat ut debet suam KCT $\mathbf{3 8 0 5}$ pater] impie KCT $\mathbf{3 8 0 6}$

C $\mathbf{3 8 0 7}$ mil...... uid $C$ 3808 Ades ...... C $\mathbf{3 8 0 9}$ Nos KCT 3811 Parente uiuo? dede me primum neci. KCT $\mathbf{3 8 1 2}$ om. KCT 3818 Spectasne] Spectare KCT 3819 fulminante] fulguranti $K C T$ 
3820 NABVC. Tua uidit ille scelera; nunc fulmen rotat, Quo te tuosque iustus Vltor obruit.

NABVZ. Concede pueros.

R. Vincor. Heu plus effera

Crudelitas, paterna quam pietas potest.

Amore uictus teneo. Da ueniam mihi.

3825 Natura patrem fortis audacem facit.

En reddo natos. Sustine extremas preces

Mitique uultu supplicem fari sine.

Superi miserrimum omnium mortalium

Fecere qui me, candido caelo caput

3830 Astrisque claris condere dederunt tibi.

Imitare Superos. Supplicem numquam premunt.

Pro me rogare desino; pueros uide

Esse innocentes.

NABVC. Patre non tali editos

In se parentis specimen hi referunt sui.

3835 Eia ante patrem liberi intereant suum.

R. Saltem parumper flere morientes dabis

Tristesque tali funeri inferias dare.

Hoc quis negauit hostis immani foret

E rupe quamquam genitus? Extremum uale

3840 Dixisse liceat et osculari liberos.

NABVC. Miserum uidere laetor, at ut fit miser

Luge, osculare, do tuis lacrimis locum

Humare fletu corpora tuorum potes.

R. Metire quantus obruat mentem dolor

3845 Quantumque rabie tumeat immani ferox

Quicumque tali flere me cogit modo.

Cara o secundis pignora in rebus, mihi

Atrocitate sortis in tanta efferae

Collacrimanda. Quae parant natis patres

3850 Reliqui peremptis, liberis cogor meis

Dare iusta uiuis. Funus en uobis paro.

Pendetis animae paruulae e collo meo.

Non profuturus uos quoque amplector parens.

Heu cur superstes fata superaui mea?

3855 Me mors uocantem spernit et ludens fugit.

3820 fulmen] poenam $K C T$ / exigit $C T$ exegit $K \mathbf{3 8 2 1}$ om. KCT $\mathbf{3 8 2 2}$ pueros] natos $K C T$ / Heu] En KCT / effera] impia KCT $\mathbf{3 8 2 7}$ Mitique] Placidoque KCT / affari KCT 3832 pueros] natos $K C /$ notos $T \mathbf{3 8 3 4}$ ante sui] hi ferunt specimen $K C T \mathbf{3 8 3 5}$ intereant] occumbant KCT 3836 Saltem morientes flere ${ }^{\mathrm{mg}}$. parumper dabis eras. $K \mathbf{3 8 3 7}$ funere $L$ 
NABUCODONOSOR - Ele viu teus crimes; neste momento, Ele faz vibrar 3820 o raio com que te destruirá, a ti e aos teus, numa justa vingança.

NABUZARDANO - Entrega as crianças.

REI - Ai, que me vejo vencido!

A crueldade selvagem pode mais que o amor paternal.

Permaneço vencido pelo amor. Concede-me este favor.

Uma natureza forte torna um pai audaz.

Entrego meus filhos; aí os tens. Mantém meus últimos desejos.

Sê indulgente e deixa um suplicante falar-te.

Os deuses tornaram-me no mais miserável dos mortais.

A ti, eles concederam-te esconder a cabeça

no cristalino céu e nos astros brilhantes.

Imita os deuses celestes. Eles nunca oprimem um suplicante.

Já não peço por mim. Repara nestas crianças

que estão inocentes.

NAbucodonosor - Não. Por virem de tal pai,

elas transportam a marca do progenitor.

Vamos, matem os filhos na presença do pai.

3835

REI - Permitir-me-ás ao menos chorar por instantes quem vai morrer

e oferecer um triste sacrifício por esta morte violenta?

Que inimigo recusaria tal pedido, ainda que a dura rocha

o tivesse gerado? Seja-me permitido

dar-lhes um último adeus e beijar meus filhos.

3840

NABUCODONOSOR - Alegra-me vê-lo infeliz, mas, para ser infeliz,

lastima-te, beija-os, dou-te oportunidade de os chorares.

Podes inundar de choro os corpos de teus filhos.

REI - Avalia toda a dor que esmaga meu espírito

e como se encontra inflado de raiva desumana

3845

quem orgulhosamente me força a chorar deste modo.

Ó meus preciosos filhos nos bons momentos da vida!

Tanta atrocidade da sorte cruel obriga-me

a chorar convosco. As honras fúnebres que outros pais

prestam a seus filhos falecidos, vejo-me eu forçado a prestá-las

3850

a meus filhos ainda vivos. Eis que preparo vosso funeral.

Estais pendurados no meu pescoço, meus pequeninos.

Abraço-vos também como um pai que vos não pode valer.

Ai! Porque ultrapassei eu o meu destino ao sobreviver-vos?

A morte despreza-me quando a chamo e foge de mim rindo.

« 3839 E] De KCT $\mathbf{3 8 4 0}$ Dicere, suprema figere liceat oscula KCT $\mathbf{3 8 4 1}$ at] ac KCTE 3842 Luge, execrande do locum lacrimis tuis KCT $\mathbf{3 8 4 7}$ Cara] Clara $K \quad \mathbf{3 8 4 9}$ Collacrimanda] Mihi lacrimanda KCT 3851 uobis] nobis $L$ 
In morte uestra uiuo. Me propter meae

Occiditis animae. Vos ego occido pater,

Non hostis ille. Sceptra quae gessi aureo

Solio locatus, nulla iam uobis dabo.

3860 Lacrimas supremo funere in uestro dabo.

NABVC. Age, sat dolori, sat tuo est animo datum.

Ad destinatam miles hos caedem rape.

FI. MA. Miserere uictor.

FI. MI. Genitor, ad mortem trahor.

R. Hunc cerne luctum, uictor. Vt prensant sinus,

3865 Pallent, tremiscunt, eiulant, agni lupo

Desaeuiente sicut imbelles tremunt.

NABVC. Quo plura tentas grauior incendit furor

Et ira gliscit. Miles, ad caedem rape.

NABVZ. Te forsan ille maeror attonitum tenet?

3870 Occide iussus; sequere morituros, pater.

FI. MA. Satis erat illa Regis inclementia;

Cur addis iram? Frangere haec aetas solet

Saeuos leones, frangere at te non potest.

FI. MI. O genitor a tuo sinu ad mortem feror.

3875 R. Quid agis, Olympi Conditor, rerum Arbiter

Mundique Rector? Facinus horrendum probas?

NABVC. Tuae nequiuit ferre perfidiae scelus.

R. Eheu secari liberos uideo meos.

NABVC. Ingens parenti sustuli mentem dolor.

3880 Sic sic doleat inimicus; ita nubem suis

Oculis oriri uideat et carissimas

Animas abire cernat in nigrum chaos.

Exanime iam cadauer unius iacet.

Quin excitatis, eia, languentem patrem?

3885 Tenete ferrum, dum parens in se redit.

Opus est ualente Rege, ne fructum necis

Huiusce perdam. Membra laxauit dolor.

Age, miles uno uulnere sequentem neca.

R. Occubuit unus, unus est poenae satis.

3890 NABVC. Si posset una caede placari fides

Violata saepe, frater in fratrem ruat

Et uterque patrem laceret. Hoc facto scies

3857 pater] parens KCT 3863 uictor] genitor $\mathbf{3 8 6 7}$ incandet $\boldsymbol{K C T E} \mathbf{3 8 6 8}$ miles] feruida KCT / caedem] mortem KCT $\mathbf{3 8 6 9}$ Te maeror ille miles attonitum mouet? KCT $\mathbf{3 8 7 0}$ morituros] perituros $K C T$ 3871-3874 om. $T \mathbf{3 8 7 3}$ at] et $K C \quad \mathbf{3 8 7 5} O$ clara mundi sidera, o caeli artifex KCT $\mathbf{3 8 7 6}$ Rectorque mundi sustines tantum nefas? KCT $\mathbf{3 8 7 8}$ Heu $K /$ uideo liberos $K C T$ 
Estou vivo na altura em que morreis. Morreis por minha causa, vidas minhas; sou eu, o vosso pai, quem vos mata, não o inimigo. O ceptro que empunhei, sentado em trono dourado, já não vo-lo transmitirei:

derramarei lágrimas por vós no vosso derradeiro funeral.

3860

NABUCODONOSOR - Vá, já foi dado tempo bastante aos teus sentimentos de dor. Soldado, arrasta-os para a imolação por mim determinada.

Filho mais velho - Tem piedade, vencedor.

FILHO MAIS NOVO - Pai, arrastam-me para a morte.

REI - Repara neste choro, vencedor; como me agarram as vestes, como empalidecem, tremem e gritam de dor, como cordeiros franzinos assustados com lobos enfurecidos.

NABUCODONOSOR - Quanto mais insistes, mais violenta minha fúria se acende e minha cólera cresce. Soldado, pega neles para a imolação.

NABUZARDANo - Será que estas lamúrias te deixam paralisado?

Recebeste uma ordem. Mata-os. Pai, segue os que vão morrer.

3870

Filho MAIS velHo - Já bastava toda a inclemência do rei; porque juntas a cólera? Esta idade costuma acalmar a fúria dos leões; a ti não te consegue impressionar? Filho maIs Novo - Ó pai, levam-me do teu regaço para a morte. REI - Que fazes Tu, Criador do Olimpo, Juiz do universo 3875 E Guia do mundo, aprovas crime tão horrendo?

NABUCODONOSOR - Ele não conseguiu suportar o crime da tua perfídia.

REI - Ai! Vejo meus filhos a serem esquartejados.

NABUCODONOSOR - Uma dor violenta fez o pai perder os sentidos.

Sofram assim os meus inimigos; que ele veja a escuridão 3880

deixar seus olhos e contemple os que mais ama encaminhando-se para o negro abismo infernal.

O cadáver inanimado de um deles já está por terra.

Eh! Porque não despertais o pai que está desmaiado?

Mantende a espada em suspenso até o pai recobrar os sentidos.

3885

Preciso do rei na posse de suas faculdades, para não perder

o sabor desta matança. A dor deixou-lhe os membros. ${ }^{146}$

Vamos, soldado, mata o outro dum só golpe.

REI - Já morreu um; um já é castigo suficiente. ${ }^{147}$

NABUCODONOSOR - Seria, se com uma só morte fosse possível aplacar a confiança tantas vezes traída; que o irmão vá ao encontro do irmão e ambos torturem o pai. Feito isto, ficarás a saber

« $\mathbf{3 8 8 1}$ clarissimas $K \mathbf{3 8 8 2} \mathrm{in}]$ ad $K C \quad \mathbf{3 8 8 3}$ Nati ecce corpus sanguine minoris rubet $K C T \mathbf{3 8 8 6}$ fructum] frustrum $K \mathbf{3 8 8 8}$ Age iam sequentem uulnere ingenti neca $K C T \mathbf{3 8 8 9}$ poenae et $m g$. C 3892 eras. fugam ante patrem $K$ / facto] pacto KCT 
Neglecta nostra pacta stabiliri manu.

R. Heu caesus alter ense natus corruit.

3895 O bruta tellus, pande secretos sinus

Et rupta tanti sceleris auctorem uora.

Vbi pietas, Tyranne, quae Regem docet

Seruare pueros? Quid querar primum, miser?

NABVC. At ut queraris tristior causam dabo.

3900 Celerate, dentur capita natorum patri.

Videat, fruatur, osculum ambobus licet

Diuide misericors. Ecquid agnoscis tuos?

R. Agnosco qui sis. Pateris infandum nefas,

Natura muta? Non ad infernum lacum

3905 Reseras patentem gurgite profundo uiam?

Non hoc Tyranno deuorato Tartari

Auges caminos? Numen iratum mihi

Placabile hosti : forsan est cordi tibi

Haec belluina immanitas? Flammam quate

3910 In me uel istum. Caede quem mauis tuo

Sacrum furori. Iudica. En habes reos.

NABVC. Omitte Superos, dum licet, natos uide.

Vsura forsan restat oculorum breuis.

R. Statuis patrem mactare post gnatos? Age,

3915 Macta; sequemur mortuos. Mortem uolo.

NABVC. Scelus est tyranni perimere tyrannum leue.

Exple uidendo lumina.

R. Explebo truces

Oculos Tyranni, dum gemo gnatos meos.

O animae dulces natorum, o corpora ferro

3920 Trunca, daret misero quis tandem occumbere patri

Et uos per nemus insuetum lucosque silentes

Posse sequi? Tenues pueri fugistis in auras

Et me crudeli captiuum linquitis hosti,

Fundentem lacrimas quas sola in morte relinquam.

3925 At tibi, qui nostro nescis mansuescere luctu,

Saeue Tyranne, Dei ultores dent praemia digna,

Qui me natorum fecisti cernere letum

Et patrios gemino foedasti funere uultus.

NABVC. Minora feci sceleribus nequam tuis.

$\mathbf{3 8 9 4}$ post alter] filius gladio occidit $K C T \mathbf{3 8 9 5}$ bruta] rupta $K \mathbf{3 8 9 6}$ tantum $K C T$ 3898 pueros] uictos $K C T$ / queror $L 3899$ tristior causam] fortius locum $K C T \mathbf{3 9 0 0}$ Celerate, patri (patre K) capita natorum date KCT $\mathbf{3 9 0 1}$ ambobus licet] natis pater KCT $\mathbf{3 9 0 6}$ Non] Nec KCT / eras. non ante hoc / Tartari] flammeas KCT 3907 caminos] lacunas KCT 3909 quate] 
que os acordos desprezados são mantidos firmes pela nossa mão. REI - Ai! O meu outro filhinho cai morto, passado ao fio da espada.

Ó terra bruta, abre tuas secretas entranhas 3895

e devora em teu seio o autor de tão horrendo crime.

Ó tirano, onde está a piedade que ensina um rei

a proteger as crianças? De que me queixarei primeiro, miserável?

NABUCODONOSOR - Mas dar-te-ei um motivo para te queixares mais.

Entreguem sem demora ao pai as cabeças dos filhos. ${ }^{148}$

3900

Que ele as contemple, as desfrute, as beije a ambas, se preferir.

Separa-as misericordiosamente. Será que as conheces?

REI - Reconheço quem és. Toleras em silêncio

crime tão monstruoso, ó natureza? Não abres

no abismo profundo um amplo caminho até ao lago infernal?

3905

Não devoras este tirano para alimentares

as fornalhas do Tártaro? Ó poderes divinos irritados comigo

e de bem com meu inimigo, será que vos agrada

esta brutal desumanidade? Lançai o fogo,

ou contra mim ou contra este. Sacrificai à vossa fúria

3910

o infame da vossa preferência. Decidi. Tendes aqui os culpados.

NABucodonosor - Deixa os deuses e contempla teus filhinhos,

enquanto podes. Talvez te reste pouco tempo para os usares.

REI - Decides matar o pai depois dos filhos? Vamos,

mata; seguiremos os mortos. Quero a morte.

3915

NABUCODONOSOR - É crime banal um tirano matar outro tirano.

Sacia os olhos olhando.

REI - Saciarei os olhos cruéis

do tirano enquanto choro por meus filhos.

Ó vidas queridas de meus filhinhos! Ó corpos mutilados

à espada! Quem daria a este pai a oportunidade de enfim morrer

3920

e, por estranhas florestas e por bosques silenciosos,

poder seguir-vos? Meus tenros filhos, fugistes para o céu

e deixais-me prisioneiro dum inimigo cruel,

derramando lágrimas que só a morte fará cessar.

Mas para ti, que não sabes comover-te com nossa dor,

cruel tirano, os deuses justiceiros hão-de castigar-te como mereces

por me teres feito assistir à morte de meus filhos

e teres desfigurado o rosto dum pai com um duplo morticínio.

NABUCODONOSOR - Fiz pouco em relação aos teus crimes infames. ${ }^{149}$

« excute $K C T 3910$ mauis] malis $K C T$ / eras. .... ante tuo 3912 O mitte $L$ / licet] potes KCT 3913 post forsan] temporis restat breuis KCT 3915 mortuos] liberos KCT 3916 tyranni] tyranno $K C T 3920$ Truncal caesa $K C T$ / miser o $K$ planctu KCT 3929 sceleribus] o add. KCT 
3930 Exigua sane poena de tam barbaro

Et impotente sumpta me lenem facit.

In parua frusta debui cadauera

laniare, acutis uerubus affixa ignibus

Torrere, mensas ponerem ut tali patri.

3935 Cur ex aperto diffluens iugulo cruor

In ora non defluxit, ut uiuentium

Biberes cruorem? Quantulum hac egi manu!

R. Adde, adde nostram si quid ad poenam potes.

Monumenta tantae linque saeuitiae omnibus

3940 Testata saeclis.

NABVC. Feruida cupido incitat

Socium necatis liberis patrem addere.

Sed comprimatur. Munus est mortem dare

Mori uolenti.

R. Parcis, Armeniae fero

Leone peior? Caede cum natis patrem.

3945 NABVC. Quia uis mori, uetabo, si nolles mori

Mortem dedissem. Genere sed leti nouo

Occumbe uiuens. Ense quo prolem neci

Iussus dedisti miles, inuiso erue

Oculos parenti. Caecus in tenebris suam

3950 Fleat orbitatem. Bella qui mecum gerunt

Sic puniuntur.

R. Perge mensuram boni

Imples tyranni. Vincis immanes feras

Crudelitate. Quid tibi restat? Doce

Odium nouercas atque feritatem tigres.

3955 Carebo luce solis, at caecus bonum

Aliquod habebo: dira non uultum tui

Bellua uidebo. Sceleris ultrices precor

Furiae sequantur ultro, quae poenam exigant

Qualem intulisti.

NABVC. Perfice extrema, inclite

3960 Ductor Nabuzardane. Post haec collige

Captiua capita, uincta Babylonem migrent, In qua triumphum rege de uicto geram.

NABVZ. Parebo iussis magne regnator tuis.

Exite tandem turba captiua; exules

3930 sane] mentis $C$ meritis $K T \mathbf{3 9 3 2}$ frustra $K T$ / cadauera] illa corpora $K C T$ 3942 comprimatur] reprimatur KCT 3945 noles $T L \quad 3948$ inuiso] o fide $K C T \mathbf{3 9 5 1}$ Sic puniuntur] sic ferantur KCT 3955 at] et $L \quad 3956$ Aliquod] Hoc rex KCT / eras. cernam tuos 
Um castigo deveras insignificante, recebido de alguém tão bárbaro

e implacável, faz de mim uma pessoa branda.

Eu deveria ter retalhado os corpos em pequenos pedaços,

fazê-los tostar pelas chamas, fixos em pontiagudos espetos,

para os servir como iguaria a um tal pai.

Por que razão o sangue que escorria de suas gargantas abertas,

3935

não se desviou para as tuas faces para, ainda vivos,

lhes beberes o sangue? Muito pouco fiz eu com esta mão!

REI - Acrescenta, se podes, alguma coisa à nossa punição.

Deixa os testemunhos de tão horrenda atrocidade gravados

Pelos séculos fora.

NABUCODONOSOR - Um forte impulso incita-me

3940

a associar o pai aos filhos assassinados.

Mas... calma! É uma benesse conceder a morte

a quem deseja morrer.

REI - Recuas? És pior do que os ferozes

leões da Arménia. Mata o pai juntamente com os filhos.

NABUCODONOSOR - Queres a morte, pois nego-ta; não quisesses morrer,

3945

e dar-te-ia a morte; em novo género de morte, porém,

cai com vida. ${ }^{150}$ Com a espada com que te obrigaram

a dar a morte aos filhos, arranca os olhos

ao odioso pai. Envolto em trevas, que ele chore desse modo

sua orfandade. Aqueles que me movem guerra

3950

são castigados assim.

REI - Prossegue. Preenches os requisitos

de um bom tirano. Superas os animais selvagens

em crueldade. Que mais te falta? Dá lições

de ódio às madrastas e de ferocidade aos tigres.

Ver-me-ei privado da luz do sol mas, mesmo cego,

3955

algo de bom terei: não verei teu rosto,

monstro abominável; peço às Fúrias vingadoras do crime

que te persigam. Tal como me castigaste,

que elas te castiguem.

NABUCOdonosor - Faz o que te resta, ilustre

general Nabuzardano. Reúne depois os prisioneiros

3960

e que eles emigrem, acorrentados, para Babilónia,

onde festejarei o triunfo pela sujeição do rei.

NABUZARDANO - Farei cumprir tuas ordens, excelso soberano.

Ponde-vos enfim em marcha, prisioneiros; deixai vossa pátria,

$\longleftarrow$ ante uultum tui / cernam tuos KCT 3957 O eras. / uultus eras. uidebo s. u. et mg. / O bellua oculos KCT 3958 sequentur $K$ / exigat $K \quad \mathbf{3 9 5 9}$ intulisti] dedisti $K C T \mathbf{3 9 6 2}$ deuicto $L$ 
3965 Migrate Solymi. Liberum uatem senem

Suique suis linquo, quo mauult loco

Vitam quietam transigat. Regem impia

Cum gente caecum in arua Babylonis feram.

\section{ChORvs Qvintvs}

\section{Hieremias. Tvrba Captiva. Rex Sedecias}

\section{Anapaesticum carmen}

H. Vrbem nostra clade sepultam

3970 Lacrimis ciues sepelite. Nigro

Aurea sordent atria fumo

Et quicquid erat nobile praeda est,

Aut materies arida flammae.

Vbi tecta auro lucida? Templi

3975 Vbi uasa? Quibus barbarus hostis,

Heu, sacrilego bibet ore merum.

СH. Lapsae inferias reddimus urbi

Accipe luctus, accipe crines

Infelicis patria uulgi

3980 Populata lue, ferro, igne, fame.

Dolor, heu, oculi fundite riuos.

H. Tabesco graui maerore senex.

Genua aegra labant, concido pronus.

Ex me flendi discite morem.

3985 CH. Praecede pater lamenta doce, Eheu, nostris fecunda malis.

Aegra tumescunt lumina, guttis

Infusa madent grandibus ora.

Dolor, heu, oculi fundite riuos.

3990 H. Ergo euersa iaces, Solyma, et deserta uaporem

Exhalas rarisque micas iam diruta flammis.

Heu, tua turba uiis conferta patentibus ibat,

At nunc pastorum raris habitabere tectis.

More sedes uiduae, cui uincla iugalia soluens

3995 Coniugis interitus, solam ad lamenta reliquit.

Tot feta imperiis, dominata tot urbibus olim,

Cogeris immani seruire ancilla Tyranno. 
exilados de Jerusalém. Deixo em liberdade, senhor do seu destino, 3965 o velho profeta. Onde bem quiser viva tranquilo sua vida. O rei cego e sua ímpia gente levá-los-ei para os campos de Babilónia.

\section{CORO V}

\section{Jeremias, grupo de Prisioneiros, Rei Sedecias \\ Canto anapéstico}

JEREMIAs - À cidade sepultada com a nossa desgraça

sepultai-a com lágrimas, cidadãos.

3970

Os pórticos dourados estão sujos de fumo negro

e tudo o que de nobre existia é pasto

ou matéria ressequida das chamas.

Onde estão os palácios de ouro reluzente?

Onde os vasos do templo? Por eles o bárbaro inimigo

3975

ai! beberá vinho com sua boca sacrílega.

Coro - Rendemos homenagem à cidade destruída.

Aceita nosso luto, aceita nossos cabelos,

pátria dum povo infeliz,

devastada pela guerra, pelo fogo, e pela fome.

3980

Ai, dor! Derramai, olhos, torrentes de lágrimas.

JEREMIAS - Sou um velho mergulhado em profundo pranto.

Vacilam-me os frágeis joelhos, quase caio.

Aprendei de mim como se chora.

Coro - Marcha à nossa frente, pai, ensina-nos lamentos,

3985

ai, remédio para os nossos infortúnios.

Temos os olhos inchados de dor,

as faces inundadas de abundantes lágrimas.

Ai, dor! Derramai, olhos, torrentes de lágrimas.

JEREmias - Jazes por terra, Jerusalém, em ruínas e ao abandono,

3990

deitas fumo e, já destruída, ofereces o brilho de chamas dispersas.

Ai! A multidão dos teus avançava em magotes, por caminhos sem fim,

e agora serás habitada por choupanas isoladas de pastores.

Ficas como viúva que, por morte do esposo,

sem laços conjugais, se entrega a lamentos, sozinha.

3995

Dona outrora de tanto poder, senhora de tantas cidades,

vês-te agora forçada a servir, como escrava, tirano cruel.

« Dolor MKCT $\mathbf{3 9 8 4}$ dicite K $\mathbf{3 9 8 7}$ Aspice uates turgida grandes $M K C T \mathbf{3 9 8 8}$ Vt parturiant (parturiunt MT) lumina guttas $M K C T \mathbf{3 9 8 9}$ Heu! Dolor $M K C T$ 
CH. Solyma hostili direpta manu

Vt sola iaces! De te superest

4000 Nil, nisi uastae cladis imago.

At nos, miseri, nos, tua proles

Captiua, procul ducimur acti.

Dolor, heu, oculi fundite riuos.

H. Te quis in obscura lacrimantem nocte reliquit.

4005 O Solyma, ut grandes oculorum in limine guttae

Gemmant, aeterni luctus monumenta futurae.

Non est qui tantis in cladibus ingemat. Omnes

Promissam rupere fidem saeuoque labantem

Te bello in pronam manibus pepulere ruinam.

4010 Hoc dedit aeterni leges uiolasse parentis,

Abiecisse pios ritus et in impia sacra

Conuertisse animos. Hinc bello et peste reuulsos

A patria Solymos, alio iubet ire Tyrannus.

CH. Horrida non nos arma Tyranni

4015 Vicere trucis; uicit auiti

Sed religio contempta Dei.

Quando uigebat pietatis amor,

Nulli fuimus praeda tyranno.

Si concidimus nostro detur

4020 Causa furori.

Dolor, heu, oculi fundite riuos.

R. Et me miserum plangite regem

Natosque meos. Caecus ad altae

Tenebrosa feror limina fossae.

4025 CH. O Rex solio qualis ab alto

Te suscepit poena cadentem.

Quicumque sedet culmine regni,

Ex te discat pendere leui

Maxima filo regna, nec altum

4030 Sic agitari fluctibus aequor.

Quotiens terras sol lustrat equis,

Nasci totiens credite Regem.

Si quis tutum transigit aeuum

Est ille Dei qui memor horret

4035 Peccare, sibi nec putat uni

Cuncta licere.

3999 iaces] manes $M K C T \mathbf{4 0 0 1}$ At] Ah $M K C T \quad \mathbf{4 0 0 3}$ Heu! Dolor $M K C T \mathbf{4 0 0 6}$ luctus] ueluti $K C T$ / futurae] doloris $K C T \mathbf{4 0 0 8}$ rupere] fregere $K C T$ / labentem $K \quad \mathbf{4 0 1 7}$ uigebat] 
Coro - Jerusalém destruída por mãos inimigas

como jazes, abandonada! De ti apenas resta

uma imagem de enorme devastação.

4000

Mas nós, miseráveis, nós, teus filhos,

somos levados prisioneiros para longe.

Ai, dor! Derramai, olhos, torrentes de lágrimas.

JEREMiAs - Alguém na noite escura te abandona chorando.

Ó Jerusalém, no limiar dos teus olhos, grossas lágrimas

4005

brilham como pérolas, testemunhas de luto eterno.

Por entre tanta ruína não há quem se lamente.

Todos faltaram à palavra dada e, pela guerra cruel, precipitaram-te com suas mãos numa ruína imparável.

Eis o resultado de violarem as leis do Pai Eterno, 4010

de banirem os ritos sagrados, de abraçarem cultos sacrílegos.

Expulsos daqui pela guerra e pela fome, obriga-os o tirano

a trocarem Jerusalém, sua pátria, por outro lugar.

CORO - Não foram as armas temíveis do cruel tirano

que nos venceram; venceu-nos o desprezo

4015

a que votamos a religião dos nossos pais.

Quando o amor a Deus era forte

nenhum tirano nos teve em suas mãos.

Se sucumbimos, lancem-se culpas

ao nosso desvario.

4020

Ai, dor! Derramai, olhos, torrentes de lágrimas.

REI - Sou um rei infeliz! Chorai por mim

e por meus filhos; conduzem-me cego

para os limiares tenebrosos do lago profundo.

Coro - Ó rei, que tipo de castigo te aflige

4025

ao seres deposto do elevado trono?

Quantos se sentam no esplendor do trono

aprendam contigo que estão suspensos de ténue fio

os maiores reinos e que a superfície serena

do mar alto não se agita assim com ondas.

4030

Sempre que o Sol visita a terra com seus corcéis

nasce um rei, acreditai.

Se alguém há que passe tranquilo seus dias,

é aquele que, lembrando-se de Deus,

receia pecar e não julga que apenas a si

4035

tudo é permitido.

« urgebat $K \quad \mathbf{4 0 2 1}$ Heu! Dolor KCTM $\mathbf{4 0 2 6}$ suscipit $L \mathbf{4 0 3 2}$ eras. regi ante credite $C$ $\mathbf{4 0 3 5}$ uni] amens $M K C T$ 


\section{APPENDICES}

\section{Appendix I}

Post Tergoque luere..., v. 34, add KC:

$\begin{array}{lllllll}\ldots & \ldots & \ldots & \ldots & \ldots & \text { Versus in caput suum }\end{array}$

Jordanus abiit. Saxa de sicco uado

Collecta memorem nemini mentem excitant

Non qui reuulsi sedibus montes suis

5 Nutare uisi, non cauernoso gemens

Terra in recessu, non uaporanti iuga

Adoperta fumo, non tot aetheria manu

Pugnata bella, quando terrenti Deo

Sine clade uictor miles Isacidum fuit

10 Veteremque pingui de solo gentem expulit

Fabricata manibus oppida alienis suum

Vertens in usum. Cuncta ceciderunt tuae

Benefacta plebi: at perfida inuenit modos

Judaea miros, se quibus legi datae

15 Et constituto foederi eriperet: uetus

Est iam querela uitulus infami aureus

Fornace coctus. Sacra contempto iacent

Neglecta cultu: tanta uix paucos capit

Haec urbs auiti moris, et tamen impios

20 Sortita coetus, omnibus monstrat locis

Erecta fictis signa numinibus. Manent

Arae en profanae gentis alienae, impii

\section{Appendix II}

Post uersum 272 add. KC:

Sed peior animo patrii in leges Dei

Infestiore. De uenenata arbore 


\section{APÊNDICES}

\section{Apêndice I}

Versos de K e C omitidos após "luere", no v. 34:

$\begin{array}{lllllllll}\ldots & \ldots & \ldots & \ldots & \ldots & \ldots & \ldots & \ldots & \text { Em direcção à nascente }\end{array}$

o Jordão fez refluir as águas. As pedras recolhidas

do leito seco do rio não avivam a memória de ninguém, nem os montes arrancados aos seus fundamentos parecendo oscilar, nem a terra gemendo na profundidade de suas cavernas, nem os cumes das montanhas envoltos em fumo vaporoso, nem tantas batalhas travadas pela mão divina quando, com Deus semeando o terror, os soldados da nação de Isaac saíram vitoriosos, sem danos sofridos, e expulsaram de terras fecundas povos antigos, usando em proveito próprio cidades edificadas por mãos alheias. Caíram no esquecimento todos os benefícios feitos ao teu povo. Pelo contrário, a pérfida Judeia arranja formas espantosas de se furtar à lei que lhe foi dada e à aliança que firmou.

É já um velho queixume o bezerro de ouro forjado na infame fornalha; os sagrados rituais encontram-se desprezados pelo abandono do culto. Esta cidade tão importante abriga muito poucos com o carácter dos seus antepassados e, habitada entretanto por bandos de criminosos, exibe em todo o lado estátuas levantadas em honra de falsos deuses. Reparem! Permanecem os altares sacrílegos dos povos estrangeiros; os ímpios...

\section{Apêndice II}

Versos de K e C omitidos após o v. 272:

“... mas de sentimentos mais hostis para com as leis do Deus de nossos pais. Tal como da árvore envenenada 
Quales seruntur ramuli, qui lurida

De matre capiunt uirus, et totum nemus

5 Subito ueneni tabida complent lue:

Ita ex iniquo patre qui sceptrum tenet

Apud Israelis turpis, et Iudae tribus.

Partu dolendo prodit infaustus puer,

In se parentis qui ferat specimen sui:

10 Vt cum pudenda ceperit sceptrum manu

Post se relinquat impie uictum patrem.

Multis ita annis regna capiuntur, uiget

Cum fraude turpi turpis impietas: auus

Quasi hoc nepotem iure sibi nasci uelit

\section{Appendix III}

Post uersum 284 add. KC:

Quin si labores inde quos subii, feras

Memorare lethum fuerat optandum semel

Constante pro te mente cum licuit mori

Non tot malorum uerticem undarent supra

5 Timidum procellae, non rebellantes mei

In iussa Domini cernerem reges feros

Et pertrahentes in sum plebem nefas.

Si stat repostum pectori excidium tuae

Afferre plebi, si dato stirpem solo

10 Exterminare penitus ingratam paras, 
se geram pequenos ramos que da pálida mãe recebem o virus e logo o bosque inteiro contaminam com a venenosa moléstia,

do mesmo modo do pai iníquo que detém o poder

sobre as tribos do indigno Israel e de Judá

sai em lastimável parto infeliz criança

que em si transportará a imagem de seu pai.

Quando em sua mão infame segurar o ceptro

deixará atrás de si o pai impiamente vencido.

Os reinos são conquistados assim há muitos anos.

Com a vergonhosa fraude reina a vergonhosa impiedade:

como se o avô quisesse que o neto lhe nascesse com este direito."

\section{Apêndice III}

Versos de K e C omitidos após o v. 272: após o v. 284:

"Mais: se aceitares lembrares-te dos tormentos que por causa

disso passei, eu deveria, duma vez por todas, ter desejado a morte quando me foi possível morrer com o meu espírito consagrado a Ti.

Não ondulariam sobre minha receosa existência tantos

vendavais de desgraças; não veria os reis revoltando-se

ferozmente contra as ordens do meu Senhor

e atraindo o povo para os seus crimes.

Se estás determinado a levar o morticínio

ao teu povo; se te preparas para exterminar

completamente este povo ingrato..." 
(Página deixada propositadamente em branco) 
NOTAS E COMENTÁRIOS 
(Página deixada propositadamente em branco) 


\section{NOTAS E COMENTÁRIOS}

Nota prévia: As siglas utilizadas ( $D E B, D M$ e $O C D$ ) remetem, respectivamente, para Dicionário Enciclopédico da Bíblia, Dicionário de Mitologia Grega e Romana e Oxford Classical Dictionary, obras referenciadas na "Bibliografia". Abreviaturas dos livros da Bíblia citados: 2 Crónicas (2 Cr); Êxodo (Ex); Ezequiel (Ez); Isaías (Is); Jeremias (Jr); Malaquias (Ml); 1 Reis (1 Rs); 2 Reis (2 Rs); Samuel (Sm).

1 (vv. 14-34) Evocação da gesta do Êxodo, com referência à vida de escravidão no Egipto (Ex. 1, 11-14), à passagem do Mar Vermelho (Ex. 14), à caminhada pelo deserto e aos prodígios que a acompanharam como a coluna de nuvens e a coluna de fogo (Ex. 13, 18-22), a água brotada da rocha (Ex. 17, 1-7), o maná caído do céu (Ex. 16) e a solene proclamação dos dez mandamentos (Ex. 20, 1-29).

${ }^{2}$ Baal, nome dado à divindade de determinado lugar, que o povo imaginava como habitando árvores sagradas, fontes, cumes de montanhas, rochedos, etc. O seu animal sagrado era o touro. Culto muito espalhado nas regiões siro-palestinenses, fortemente combatido pelos profetas em Israel, designadamente Jeremias. (DEB).

3 Penates, divindades romanas que protegiam o larário (uma espécie de capela) da casa. Também o estado romano, tal como cada casa, possuía os seus Penates ( $D M)$. Neste passo, a expressão terá o sentido humanista de "o Deus da nossa pátria".

4 (vv. 89-99) Repassados de ironia, estes versos fustigam a excessiva confiança nas armas.

5 (vv. 103-107) Ezequias, rei de Judá, entre 721-693. Autor duma reforma religiosa que acabou com todos os abusos no culto. Preparou-se devidamente para a guerra, fortificando Jerusalém e garantindo a provisão de água para a cidade com a construção dum túnel entre a fonte de Gion e a piscina de Siloé. Deste modo conseguiu resistir ao cerco que Senaqueribe impôs à cidade e a que pôs subitamente termo, após a morte de milhares de soldados seus. (DEB). Cf. 2 Rs 19.

6 (vv. 120-122). Paretónio: cidade do Baixo Egipto, na fronteira com a Líbia. A mesma alusão aparece também nos vv. 2292 e 2875. Símile em que o dramaturgo recorre às características da vulgar papoila para exprimir a extrema fragilidade do Egipto face ao poderio de Nabucodonosor.

7 Saul, primeiro rei de Israel, cerca de 1040-1010. (DEB). Morreu de forma trágica, atirando-se sobre a própria espada, após combate fracassado contra os Filisteus. Cf. 2 Rs 19.

8 (vv. 134-146) Alusão aos acontecimentos mais recentes da história de Judá, referindo o destino trágico dos dois antecessores de Sedecias, Joaquim e Jeconias, respectivamente, o $18^{\circ}$ e $19^{\circ}$ reis de Judá. Sedecias era irmão do primeiro. (DEB). Cf. Jr 22, 13-19; 2 Rs 24,6.

9 (v. 140-141) Como se pode ler em Jr 36, o rei Joaquim queimou o rolo das profecias de Jeremias. 
10 (vv. 204-209) Elias, profeta no tempo do rei Acab (primeira metade do séc. IX a. C.) e de sua esposa Jezabel, grande promotora do culto de Baal. Perseguido por esta, refugiou-se no cimo do monte Horebe. (DEB). Cf. 1 Rs 19,1-8.

11 Os quatro primeiros versos desta fala de Jeremias imitam o início da primeira Catilinária de Cícero. Cf. Cic., Cat. I, 1.

12 (vv. 266-8) Nova evocação da gesta do Êxodo, com a alusão à travessia do Mar Vermelho. Cf. n. 1 .

13 (vv. 278-9) Jeremias foi perseguido por Joaquim, rei de Judá, por ter criticado duramente a sua actuação como rei. Cf. n. 9. Sobre actos seus de violência contra outros profetas, cf. Jr 26, 7-24.

${ }^{14}$ Esta cena, que junta Jeremias e o Oráculo, baseia-se em Jr 27.

15 Edom: apelido de Esaú, como ancestral dos Edomitas. Estes eram uma tribo semita cujo território, protegido por inúmeras fortalezas nas suas fronteiras, situava-se a sul do Mar Morto, dos dois lados de Arabá até ao golfo de Acabá. (DEB).

16 Moab: tribo semita. Os Moabitas, inicialmente nómadas, ter-se-ão estabelecido por volta do séc. XIII a.C. na Transjordânia, entre o Mar Morto e o deserto sirio-arábico. (DEB).

17 Amon. Amonitas: tribo aramaica que no séc. XII a. C. se sedentarizou na extremidade oriental do actual Belqa, a oriente do rio Jordão. (DEB).

18 (v. 333) Este verso, na sua expressão latina, ter-se-á inspirado em Verg. Aen. IV, 661.

19 O império Babilónico sucumbiu perante o império persa, de Ciro, em 539. Jerusalém fora conquistada em 576. Jeconias, que fora rei durante escassos 3 meses, quando contava apenas oito anos, viu ser-lhe concedida a liberdade no trigésimo sétimo ano de cativeiro, por Evilmerodaque, filho de Nabucodonosor. (DEB).

${ }^{20}$ Alusão às doze pragas do Egipto. Cf. Ex 7-11.

21 Áfrico: vento do sudoeste; Bóreas: vento do norte. Tanto um como outro são ventos de tempestade. O último é representado como um demónio alado, com uma grande força física e normalmente vestido com uma túnica curta plissada. (DM).

22 Tiro, cidade da antiga Fenícia, situada no litoral do actual Líbano.

23 Alusão ao tributo anual em ouro a que Israel se obrigara em relação a Babilónia. Cf. $2 \operatorname{Cr} 36,3$.

24 Orco: o espírito da morte, nas crenças populares romanas, representado em pinturas funerárias etruscas como um gigante barbudo e hirsuto. (DM). Aqui, uma das muitas designações do Inferno, de influência clássica, como Tártaro, por ex., no verso anterior a este.

25 "curules rotas" ("as rodas do carro"): expressão inserida numa perífrase astronómica alusiva ao movimento do sol. Recorrente no texto da tragédia.

26 (vv. 521-23) Cf. Jr 27,8

27 Ínfula, faixa sagrada, de lã branca, que cingia a fronte dos sacerdotes e enfeitava as vítimas.

28 Acto I, Cena VI: cf. Jr 27,12-15.

29 (vv. 577-582) Cf. 2 Cr 36,13.

30 Alusão ao culto a Baal, cujo animal sagrado era o touro. (DEB). Cf. Jr 3,19-25. 
31 "Perge, detestabilis": possível decalque de Sen. Thyest. 23.

32 (vv. 643-45) Nova alusão ao célebre acontecimento da água brotando da rocha, por acção de Moisés. Cf. Ex 17, 6.

33 (vv. 723-729) Cf. Jr 29.

${ }^{34}$ Natan, profeta que ficou célebre pela grande influência que exerceu sobre o rei David. Cf. 2 Rs 12,1-13.

35 (vv. 825-828) Símiles em acumulação, ilustrando o condicionamento dum rei por favores e adulações.

36 Cf. Ex 32.

37 (vv. 852-54) Cf. Jr 17,1.

38 Samuel e Moisés, figuras cimeiras na história espiritual de Israel. O primeiro (sacerdote, juiz e profeta) desempenhou um papel decisivo na instituição da monarquia em Israel. Moisés é bem conhecido como o grande libertador de Israel da escravidão do Egipto, conduzindo o povo no regresso à Terra Prometida. Para Moisés, cf. Ex 32,11-14; para Samuel, 1 Rs 7,5-9.

39 Fúrias: génios do mundo infernal, nas crenças populares romanas. Assimiladas às Erínias gregas, deusas violentas, cuja função essencial, nos Poemas Homéricos, é a vingança do crime, particularmente as faltas contra a família. (DM).

40 Profeta que impugnou a convicção de Jeremias de que todos seriam subjugados a Babel. (DEB).

41 Acto II, Cena II: cf. Jr 28,1-11.

42 Estes vasos, várias vezes referidos no texto da Sedecias, integravam o tesouro do templo, que incluía outros objectos em ouro, necessários ao serviço do templo, mandados fazer pelo rei Salomão e especificados em 1Rs 7, 48: o altar, a mesa da consagração, candelabros, florões, bacias de aspersão, turíbulos, etc, tudo isso levado para Babilónia por Nabucodonosor, num saque implacável, como se pode ler em 2Rs 25, 13-17.

43 Lúcifer, tradução latina do gr. phosphoros, com que se designa a estrela da manhã. Usado na poesia como personificação do astro que anuncia a aurora e traz a luz do dia.

${ }^{44}$ Acto II, Cena III: cf. Jr 28,12-14.

45 (vv. 1012-23) Cf. Jr 28,14-16.

46 (vv. 1047-51) Símiles em acumulação, utilizando as imagens da contínua ondulação marítima e do amontoar de nuvens no céu como forma de exprimir poeticamente a sobrecarga de preocupações que afligem Jeremias. O símile da chuva é de génese bíblica. Cf. Is 55,10.

47 (vv. 1057-8) Símile de inspiração bíblica: Deus põe à prova quem mais ama. Cf, $M l 3,2$.

48 (vv. 1139-1141) Cf. 2 Cr 36,13.

49 (v. 1217) Possível alusão a Lucius Quinctus Cincinnatus, nomeado ditador em 458 a. C., para acudir à cidade de Minucius, atacada pelos Équos. Resolvido o problema com a libertação da cidade, logo resignou ao cargo de ditador, retirando-se para a sua quinta transtiberina. Ficou na tradição como um exemplo de desapego ao poder. (OCD). Cf. Liv. 3,26,7-11.

50 (vv. 1247-8) Recurso ao tropo da perífrase como meio de referir poeticamente o nascente e o poente.

51 (vv. 1258-61) Ecos aparentes, nestes versos, de Horácio (Epodo II) e de Virgílio (Ecl. 1). 
52 (vv. 1294-1318) Discurso de exortação bélica, em tom épico, como o indicam os versos hexâmetros dactílicos.

53 o Averno, lago da província italiana da Campânia onde os poetas situavam uma das bocas do Inferno, era uma designação muito usual deste. Na Sedecias regista cinco ocorrências.

54 (vv. 1346-50) Alusão ao célebre combate de David e Golias (1Sm. 17, 41-54).

55 "Coniecta sors est": eco da frase de César ("alea iacta est" = a sorte está lançada) referida por Suetónio (Caes. 31).

56 (vv. 1387-88) Ecos do Sl 138.

57 Nova alusão ao rei David como modelo de piedade. Cf. 2 Sm 12.

58 Acto II, Cena VIII: cf. Jr 28,17.

59 (vv. 1520-21) Símile ilustrativo da insensibilidade de espírito, com recurso à imagem da impassibilidade das rochas fustigadas pelas ondas.

60 Acto III, Cena I: cf. Jr. 24; 19,1-14. Nos vv. desta cena testemunham-se os aspectos mais duros da profecia de Jeremias.

61 (vv. 1546-1551) Cf. Ex 3,8; 14.

62 Símile aparentado ao dos vv. 1520-21.

63 Sodoma, cidade de Lot, referida no livro do Génesis (10, 19; 13, 12ss, etc.). Por causa da sua imoralidade, foi destruída juntamente com Gomorra. Essa destruição ficou como o símbolo dos severos julgamentos de Deus. (DEB).

64 Ou seja, o Vale da Matança, nome que lhe advém do sangue que o inunda ( $\mathrm{Jr}$ 7, 32; 19,4-6).

65 (vv. 1614-18) Cf. Jr 7,33; 19,7.

66 (vv. 1620-22) Cf. Jr 19,8.

67 (vv. 1627-33) Cf. Jr 19,9.

68 (vv. 1641-42) Símile retirado de Jr 19, 10-11.

69 Símile cuja estrutura e conteúdo indicia influências do Tiestes de Séneca (vv. 732-740) e da Eneida de Virgílio (IX, 339-345).

70 (vv. 1683-1685) Cf. Jr 4,13; 8,16.

71 Cf. Suet. Caes. 31. Vide n. 52.

72 (vv. 1738-44) Nova alusão à mortandade no exército de Senaqueribe, no tempo do rei Ezequias, já referida no prólogo, v. 103 e ss. Cf. 2 Rs 19, 35-37.

73 Provável influência virgiliana nesta caracterização da Fama ("...terris didita fama": Aen., VIII, 132).

74 (vv. 1820-23) Sugestivo símile, com recurso a um fenómeno de natureza inorgânica (o crepitar das folhas de loureiro em combustão) para aludir à agitação bélica.

75 Verso decalcado em Sen., Herc. Fur. 342.

76 Marte, personificação da guerra.

77 (vv. 1940-42) Dois símiles em acumulação, sugestivos de rapidez na acção. 
78 Acto III, Cena III: cf. Jr 19,14-15; 20,1-2.

79 O tigre e o leão são aqui várias vezes referidos como ilustração da crueldade.

80 "Exhorruistis": ecos de Sen. Thyest. 744.

81 (vv. 2063-67) Cf. Jr 7,32-34; 16,9; 19,10-11.

82 (vv. 2108-09: Cf. Virg. Aen. VIII,596.

83 (vv. 2132-38) Cf. Ez 17,11-19.

${ }^{84} \mathrm{O}$ aríete e a tartaruga designam aqui dois dispositivos de guerra usados pelos Romanos. O primeiro consistia numa máquina de guerra com que se derrubavam as muralhas ou as portas das cidades sitiadas, com uma extremidade em forma de focinho de carneiro (em latim ariete); o segundo, na formação duma carapaça com os escudos dos soldados, sob a qual estes podiam avançar e atacar em formação, protegidos dos golpes dos adversários.

85 Alusão ao Inferno, com a menção do Averno e do Aqueronte. Este último é o rio que as almas devem atravessar para chegar ao reino dos mortos. Um barqueiro chamado Caronte encarrega-se de o fazer. $(D M)$.

86 Os Manes, nas crenças dos Romanos, são as almas dos mortos (DM).

87 2173-80: Notos: ventos do sul. Símile bem expressivo em que a violência da tempestade em alto mar, causadora de naufrágios, ilustra a chacina imensa que Nabucodonosor gostaria de ter provocado. Possíveis influências clássicas, designadamente de Horácio (Odes I, 9, 10 ss.).

88 Manípulo, em contexto militar, designa uma das subdivisões da legião romana.

89 (vv. 2237-2296) Cf. Jr 37,5.

90 (2325-2336) Símile. A importância do leme na navegação é comparada à das leis no rumo certo traçado para as sociedades.

91 Acto IV, Cena IV: Cf. Jr 20,1-6.

92 (vv. 2575-76) Cf. Jr 20,3-4.

93 (vv. 2623-2645) Cf. Jr 20,4-6.

94 Acto IV, Cena V: cf. Jr 37,3-10.

95 Ecos de Hor. Carm. I, 11.

96 (vv. 2722-25) Símile sobre os efeitos do medo infundado, com recurso ao bem conhecido comportamento da corça assustadiça.

97 Acto IV, Cena VII: cf. Jr 37,6-12.

98 (vv. 2803-2809) Símile. O rio galgando as margens, fora de controlo, para ilustrar a onda de loncura desenfreada que tomou conta dos espíritos.

99 Acto IV, Cena VIII: cf. Jr 37,6-12.

100 (vv. 2871-2889) Cf. Jr 37,7-9.

101 (vv. 2892-95) Cf. Jr 37,10.

102 Cf. Jr 37,12. Anatoth é a terra natal de Jeremias, habitada pelos Benjaminitas. No enredo, o profeta sai de cena pela porta "Beniamaea" (v. 2773). O nome sobreviveu na actual 'Anata', a nordeste de Jerusalém. (DEB).

103 Acto IV, Cena IX: cf. Jr 37,12-14. 
104 Seg. Jr 37, 15-16, a casa de Jónatas, escriba da corte, foi utilizada como prisão, numa das suas celas subterrâneas.

105 (vv. 2957-2961) Símiles em acumulação, para acentuar o avanço impetuoso de Nabucodonosor, através das imagens do tornado súbito e da floresta em chamas.

106 Cf. Jr 4,13; 8,16.

107 Acto IV, Cena XII: Jr 39,1.

108 Acto IV, Cena XIII: cf. Jr 37,17-21.

109 (vv. 3107-19) Cf. Jr 37, 18-20.

110 Símile assente num facto da vida doméstica.

111 Acto IV, Cena XIV: cf. Jr 38,1-3.

112 (vv. 3159-66) Cf. Jr 38, 2-3.

113 Acto IV, Cena XV: cf. Jr 38,4-6.

114 (vv. 3200-3202) Cf. Jr 38,5.

115 Báratro: buraco profundo, abismo onde se precipitavam os condenados em Atenas. Neste caso, seg. Jr 38,6, trata-se do poço do príncipe Malquias, que ficava no pátio do palácio da guarda, onde não havia água, mas apenas lama.

116 Coro IV: cf. Ez 22.

117 Preferimos deixar intacta a expressão latina, a traduzi-la por "benéfica Boa-Fé", pensando noutra muito corrente, a saber, "Alma Mater".

118 (vv. 3275-79) Símile para ilustrar a avareza. Possíveis influências virgilianas ("Aut qui diuitiis soli incubuere repertis / Nec partem posuere suis" - Eneida VI, 610-11).

119 Acto V, Cena II: cf. Jr 38, 7-13.

120 (v. 3390 e ss.) Inicia-se aqui, porventura, a cena mais movimentada da tragédia, com a simulação do combate de assalto à cidade de Jerusalém, muito comentada na correspondência jesuítica devido à sua espectacularidade. Cf. anexos 1 e 2 da "Introdução". Fontes bíblicas: Jr 39, 1-3; 52, 12-16; 2 Rs 25, 8-11.

121 Acto V, Cena IV: cf. Jr 39,4; 2 Rs 25, 3-4.

122 Cf. Sen. Oed. 6.

123 Cf. Sen. Thyest. 423.

124 Acto V, Cena V: cf. Jr 39,4.

125 Acto V, Cenas VI e VII: cf. Jr 39,8-9.

126 (vv. 3483-90) Cf. Sen. Thyest. 723-740. Virg. Aen. IX, 339-345.

127 Reblata: a actual cidade de Rible, na margem direita do Orontes. Nela estabeleceu Nabucodonosor o seu quartel general, na sua expedição palestinense de 588/586, pressuposta no enredo da Sedecias. (DEB).

128 Acto V, Cena VIII: cf. Jr 39, 11-14.

129 Acto V, Cena IX: cf. Jr 39,5. Expressão de regozijo de Nabucodonosor (vv. 3550-55), decalcada en Sen. Thyest. 885-888 e que recorrerá mais vezes, tanto para a mesma personagem (vv. 3696ss) como para Nabuzardano (vv. 3666-8 e 3689-91). 
130 (vv. 3564-5) Hipérbole astronómica alusiva ao percurso diurno do sol, aqui designado por Titã.

131 Acto V, Cena X: cf. Jr 38, 11-12; 40, 1-4.

132 (vv. 3629-37) Cf. Sen. Clem. II, 34.

133 Acto V, Cena XI: cf. Jr 39,5.

134 (vv. 3666-72) Cf. Sen. Thyest. 885-919.

135 Vento de sudoeste, filho de Eos (a Aurora) e de Astreu ou de Tífon. (DM).

136 De novo surge aqui decalcado o Tiestes de Séneca, no passo referido na n. 129. Cf. Ainda os vv. 279 e 979 da mesma tragédia.

137 Acto V, Cena XII: cf. Jr 39,6-7. Nesta cena e na seguinte revela-se de forma especial a influência do modelo Séneca, com decalques das tragédias Tiestes, Medeia e Édipo. Sobre a imitatio de Séneca na Sedecias cf. Manuel Barbosa, "Pervivências de Séneca no teatro jesuítico. O caso da tragédia Sedecias de Luís da Cruz" in De Augusto a Adriano. Actas de Colóquio de Literatura Latina (Lisboa, 2000. Novembro 29 - 30), coord. Aires A. Nascimento, Euphrosyne, Centro de Estudos Clássicos, Lisboa 2002, pp. 221-229.

138 (v. 3717) Cf Sen. Agam. 57-107.

139 (vv. 3724-3726) Cf. Id. Thyest. 176-177; 215-217.

140 (v. 3728) Ibid. 494-495.

141 Acto V, Cena XIII: cf. ibid. vv. 970-1112.

142 (vv. 3778-9) Cf. Id. Med. 1004-1005.

143 (v. 3787) Ibid. 997-998.

144 (vv. 3794-95) vf. Id. Oed. 936-38.

145 Cf. Id. Thyest. 1100.

146 (vv. 3884-87) Cf. Id. Med. 1016-1017 e Thyest. 900-01.

147 (v. 3889) Apelo angustiado de Sedecias que decalca idêntico de Jasão a Medeia, para que esta não lhe mate o outro filho (Sen., Med.1008).

148 (vv. 3900-11) Cf. Id. Thyest. 1004-1023; 903-906; Med. 1024.

149 (vv. 3929-37) Com uma ironia cruel que remete para Atreu e Medeia, Nabucodonosor confessa a sua insatisfação com o grau de castigo infligido a Sedecias. Cf. Sen. Thyest. 760-761; 765; 1053-5; 1060; 1063-1064; e Med. 1009-13.

150 (vv. 3946-47) De novo a ironia cruel de Nabucodonosor, mas desta vez inspirada pelo Édipo de Séneca. Cf. Sen. Oed. 949-51. 
(Página deixada propositadamente em branco) 


\section{ÍNDICE ONOMÁSTICO}

Abdemelhec (personagem): 65, 274, 277

Abraão: 71, 87, 135

Acab, antr: 324

Acabá, top.: 324

Acónito, planta: 231

África: 17, 48

Áfrico, mit.: 97, 163, 324

Alberti, Leo Battista (humanista e arquitecto): 31

Alcácer-Quibir, top.: 8, 37

Álvares, P. Manuel, S. I.: 6

Amon (personagem): 95, 97, 101, 324

Amonitas (tribo): 61, 324

Ananias (personagem): 20, 21, 22, 23, 52, 60, 51, 66, 67, 125, 161, 163

Anatoth, top.: 249, 327

Anjo de Jerusalém (Prólogo): 19, 33, 61, 67, 71

Aqueronte, mit.: 203, 295, 327

Aquilão, mit.: 25, 119

Arabá, top.: 324

Aristóteles: 28, 31, 35, 36

Arménia, top.: 29, 171, 311

Assíria, top.: 26, 175, 201, 279

Astreu, mit.: 329

Aurora, mit.: 147, 329

Averno, top.: 44, 125, 131, 151, 203, 231, 251, 326, 327

Azevedo, P. Inácio de, S. I.: 7

Baal, mit.: 25, 32, 73, 107, 323, 324

Babel, top.: 325

Babilónia: 175, 179, 181, 183, 201, 205, 213, 231, 233, 247, 249, 253, 283, 291, 297, 311, 313, 324, 325

Barbaro, Danielo (humanista e arquitecto): 31 Barreira, João (tipógrafo): 6

Baruc, profeta: 22
Belqa, top.: 324

Benjaminitas (tribo): 327

Bordéus, Colégio de la Guyenne, de: 18

Bóreas, mit: 97, 324.

Braga, Colégio de S. Paulo de: 7, 8, 18, 46

Bragança (Colégio): 8, 10

Buchanan, Georges (humanista): 18, 35

Iephthes (tragédia): 35

Baptistes (tragédia): 18

Caldeia, top.: 303

Câmara, P. Luís Gonçalves da, S. I.: 17, 18, 36

Câmara, Martim Gonçalves da: 18

Campânia, top.: 326

Caronte, mit.: 327

Cardon, Horace (tipógrafo, sécs. XVI-XVII): 9, 38, 40

Cincinato (cidadão romano): 325

Cinthio, Giambattista Giraldi (humanista, séxc. XVI): 36

Ciro, rei persa: 324

Coimbra, Colégio das Artes de: 5, 6, 7, 8, 10, $14,17,18,38,39,40,46,48,56,59$

Coimbra, Mosteiro de Santa Cruz de: 39, 55

Crato, Prior do: 8

Cruz, Leonardo (pai de Luís da Cruz): 5

Cruz, P. Luís da Cruz, S. I., passim

Iosephus (tragicomédia): 8, 11, 40

Manasses (tragicomédia): 8, 11

Polychronius (écloga): 8, 11

Prodigus (tragicomédia): 8, 11, 17, 38, 40

Sedecias (tragédia): passim

Vita Humana (comédia): 8, 11, 31, 40

David (rei de Israel) 77, 113, 151, 157, 269, 325,326

Duarte, D. (príncipe): 46, 47

Edom (personagem): 61, 95, 97, 101, 103, 324 
Edomitas, etn.: 324

Egipto, top.: 19, 20, 27, 67, 73, 77, 93, 97, 167, $185,187,207,209,211,217,235,247,253$, $255,257,323,324,325$

Elias, profeta bíblico: 83, 324

Eos, mit.: 329

Équos, etn.: 325

Erínias, mit.: 325

Esaú, antr: 324

Eufrates, top.: 285

Euro, mit.: 297, 329

Evilmerodaque (rei assírio): 324

Évora, Colégio do Espírito Santo de: 8, 38, 40,41

Ezequias (rei de Judá): 75, 323, 326

Faro, top.: 209

Fama, mit.: 161, 181, 209, 237, 297, 326

Filipe II, rei: 8

Franco, Antonio, S. I.: 8, 37, 54, 55

Frutuoso, S.: 47

Fúrias, mit.: 26, 137, 165, 245, 311, 325

Gambara, Lorenzo, S. I.: 35

Ganges, top.: 17

Gedelias (personagem): 61, 63, 67, 173, 175, $177,179,187,253$

Gerardo (santo): 47

Gesù, Igreja del: 31

Gion, top.: 323

Godolias (personagem): 42, 61, 63, 65, 175, 179, 187

Golias (gigante filisteu): 326

Gomorra, top.: 289, 326

Gouveia, André de (humanista, séc. XVI): 14

Gracida, Ir. Nicolau, S. I.: 5

Henrique, Cardeal D.: 17, 46, 47, 59

Horácio (poeta latino): 325, 327

Idumes, cf. Edom

Inferno (-s), mit.: 44, 165, 271, 295, 324, 326,327

Israel: 18, 319, 323, 324, 325,

Janeiro, Rio de, top.: 17

Jeconias (rei de Judá): 77, 323, 324

Jeremias (personagem): 19, 20, 21, 22, 24, 25, 26, 27, 32, 61, 63, 65, 67, 69, 79, 109, 173, 225, 229, 259, 289, 323, 324, 325, 326, 327

Jerias (personagem): 63

Jerusalém, top.: 19, 20, 21, 25, 27, 30, 32, 33, $47,61,67,71,73,75,79,83,89,91,99$, 103, 111, 115, 119, 123, 131, 133, 139, 141, $143,147,149,155,161,163,165,167,169$,
$173,175,179,181,187,189,193,199,201$, 207, 211, 213, 215, 233, 235, 241, 247, 249, $255,257,261,263,265,269,273,277,279$, 281, 283, 287, 289, 291, 293, 295, 297, 313, $315,323,324,327,328$

Jezabel (esposa de Acab): 83, 324

João, Ir. Domingos, S. I.: 10, 34, 46, 47

João III, D., rei: 14, 47

Joaquim ( $18^{\circ}$ rei de Judá): 87, 89, 323, 324

Jónatas (escriba): 32, 69, 253, 263, 328

Jordão (rio): 317,324

Judá: 19, 23, 25, 27, 28, 77, 123, 165, 233, $319,323,324$

Lisboa: 59

Lisboa, Colégio de S. Antão de: 39

Lopes, Leonor (mãe de Luís da Cruz): 5

Lopes, P. Manuel, S. I.: 5

Loyola, S. Inácio de: 15, 54

Lúcifer, astr: 129, 131, 137, 325

Lusitânia: 37, 46, 48, 54

Malquias (príncipe judeu): 328

Manes, mit.: 203, 229, 327

Maria, Frei Francisco de Santa (músico de Santa Cruz, séc. XVI): 39

Marte, mit.: 187, 199, 326

Martinho (São): 47

Mártires, D. Frei Bartolomeu dos (arcebispo de Braga, séc. XVI): 7, 46

Matança, Vale da, top.: 326

Mater, Alma: 328

Messina, Colégio de: 15, 20

Minucius (terra natal de Cincinato): 325

Moab, top.: 61, 91, 97

Moabitas (tribo): 324

Moisés: 109, 115, 325

Morto, mar: 324

Nabucodonosor (personagem): 19, 20, 21, 25 , $26,27,30,33,42,47,59,63,65,67,69$, 75, 97, 105, 115, 141, 173, 175, 181, 201, 205, 207, 209, 217, 231, 249, 253, 255, 257, 287, 289, 291, 293, 295, 297, 299, 301, 303, 305, 307, 309, 311, 323, 325, 327, 328, 329

Nabuzardano (personagem): 24, 30, 42, 63, 65, 67, 69, 199, 205, 207, 209, 210, 211, $255,257,279,283,285,295,297,299$, $303,305,307$

Natan (profeta): 113, 325

Necao (faraó): 33, 67, 69, 207, 209, 231, 255

Neregel (personagem): 65, 285, 287, 289, 291, 293, 295, 297 
Nilo, rio: 17, 97, 185, 207, 231

Noto (vento do sul): 203, 327

Olimpo, mit.: 87, 129, 131, 165, 167, 171, 175, 197, 199, 275, 293, 307

Orco, mit.: 99, 117, 324

Oreb, Monte: 83

Orontes (rio): 328

Paretónio, top.: 77, 211, 247, 323

Paulo III, Papa: 14, 15

Penates, mit.: 73, 277, 323

Perpinhão, P. João Pedro, S. I.: 6, 31

Pinto, F. Constantino (possuidor de códice): 39

Possevino, P. Antonio, S. I.: 8, 35

Rabsaces (personagem): 64, 65, 285, 287

Rates, S. Pedro de: 47

Reblata, top.: 287, 328

Rible, top. Ver Reblata.

Ricci, Bartolomeu (humanista, séc. XV): 36

Romanos, etn: 327

Safatias (personagem): 61, 63, 179,

Salomão (rei bíblico): 325

Samuel (figura bíblica): 123, 325

Saul ( $1^{\circ}$ rei de Israel): 77,323

Sebastião (rei de Portugal): 17, 17, 31, 36, 37, 40, 46, 47, 48, 59

Sedecias (personagem): 19, 20, 21, 22, 23, 24, $26,27,28,30,37,42,61,63,65,67,69$, 77, 79, 87, 93, 95, 97, 103, 105, 107, 171, $205,255,285,303,323,329$

Senaqueribe (rei da Assíria): 177, 323, 326

Séneca (escritor latino): 22, 23, 26, 29, 30, 35, $36,43,44,55,326,329$
Édipo: 30, 329

Medeia: 30, 329

Tiestes: 29, 30, 326, 329

Serlio, Sebastiano (humanista e arquitecto, séc. XVI): 31, 33

Serrão, P. Jorge, S. I.: 18, 53

Sídon, top.: 91

Siloé, top.: 323

Soares, P. Cipriano, S. I.: 6

Soares, Ir. Damião, S. I.: 34, 48

Soares, João, (bispo de Coimbra, séc. XVI): 47

Sodoma, top.: 169, 289, 326

Sofonias (personagem): 63, 235, 237, 239, 241, 243, 245, 249

Tártaro, mit.: 99, 101, 203, 265, 309, 324

Tífon, mit.: 329

Tiro, top.: 61, 91, 95, 97, 103, 324

Titã, mit:: 127, 289, 329

Tonante, mit.: 26, 44, 77, 93, 99, 111, 117, 127 , 129, 155, 259, 289, 293

Transjordânia, top.: 324

Trento, Concílio de: 15

Venegas, P. Miguel, S. I: 6, 7, 18, 31, 39

Saul (tragédia): 18, 31

Acab (tragédia): 18

Absalon (tragédia): 18

Vermelho (Mar): 71, 77, 87, 165, 323, 324

Vitória, mit.: 147, 285, 291

Vignola, Giacomo (humanista e arquitecto, séc. XVI): 31

Viperano, Giovanni Antonio, S. I: 19, 20, 54

Vitrúvio (arquiecto romano, séc. I a. C.): 31, 32 
(Página deixada propositadamente em branco) 


\section{ÍNDICE GERAL}

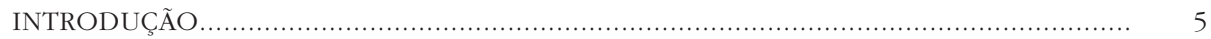

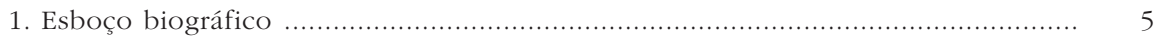

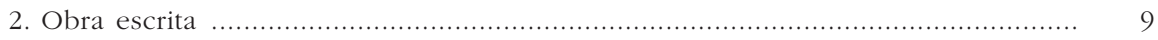

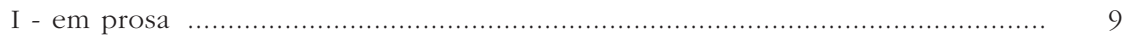

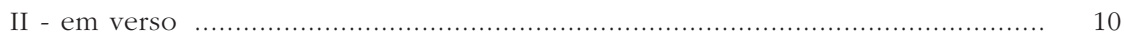

3. Tragédia Sedecias e humanismo jesuítico ……................................................. 14

4. Poética da Sedecias ................................................................................... 18

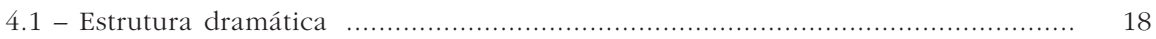

4.2 - O pensamento da fábula ........................................................................... 24

4.3 - A elaboração discursiva (ou elocutio) …….............................................. 28

4.4 - O modelo Séneca ................................................................................ 30

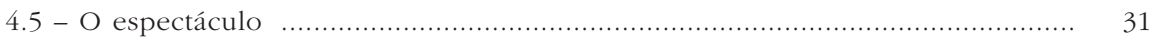

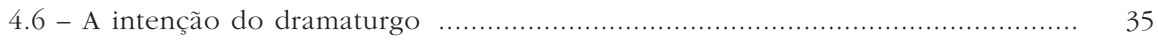

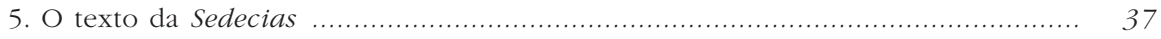

5.1 - Colação dos testemunhos e fixação textual ................................................ 37

5.2 - Critérios de edição ……….................................................................. 41

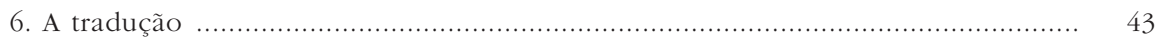

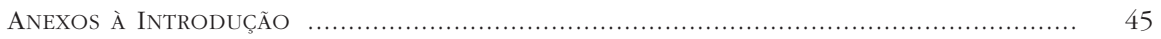

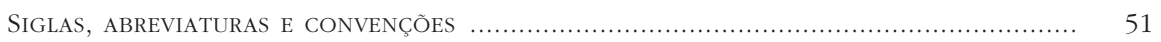

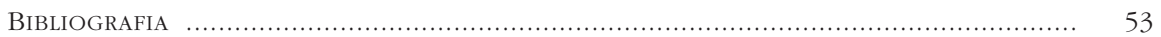

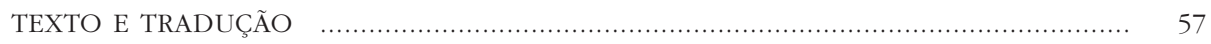

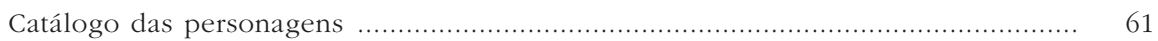

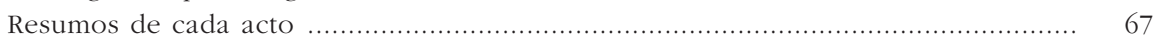

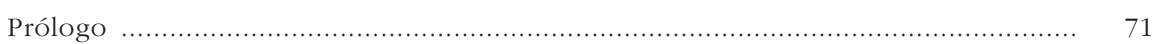

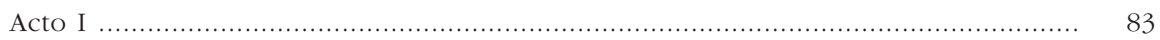

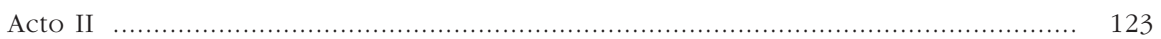

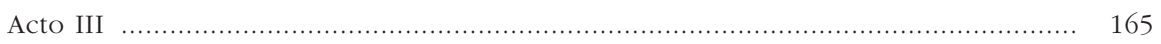

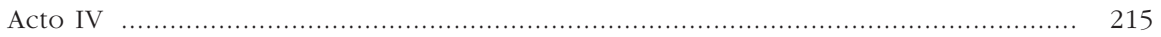

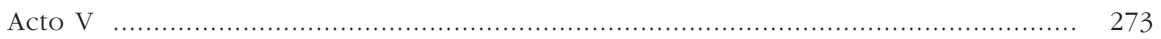

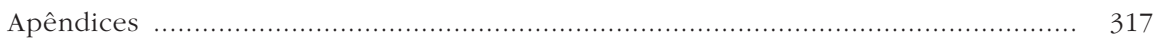

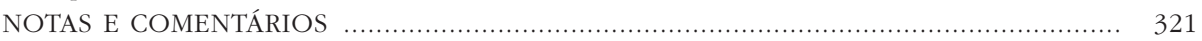

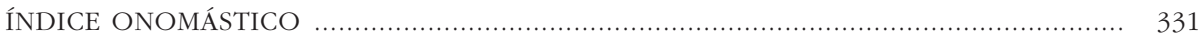



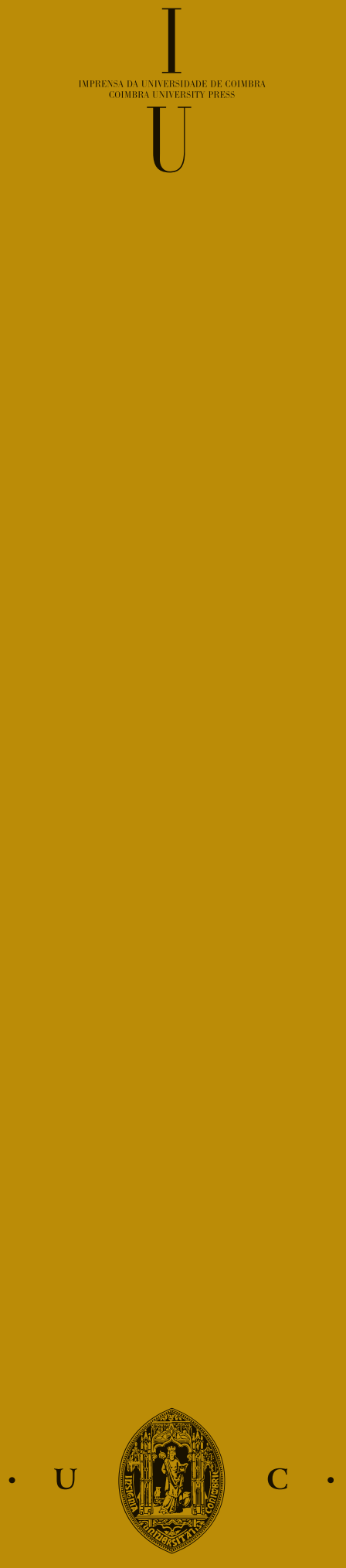